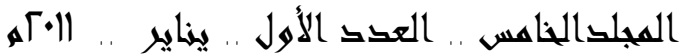

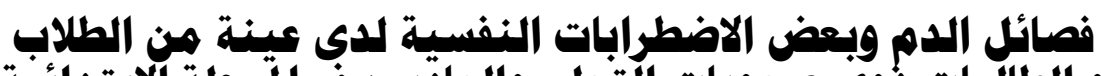

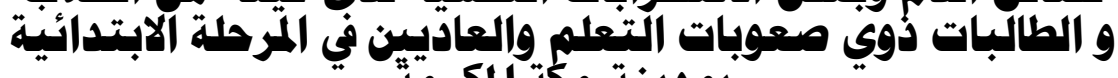

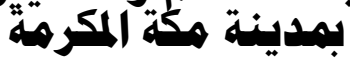

أ. إبتسام محمل أحمل العلمي

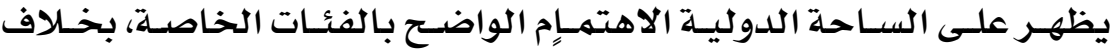

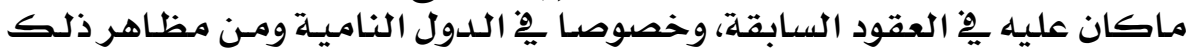

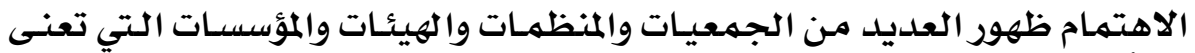

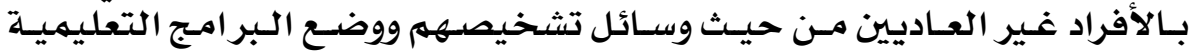

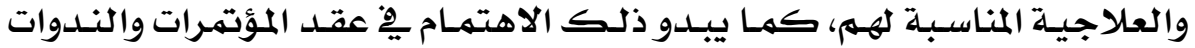

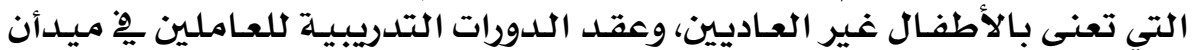

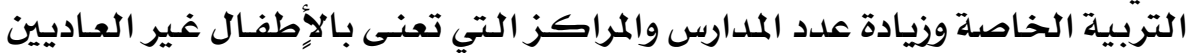

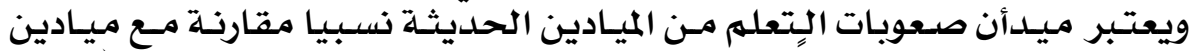

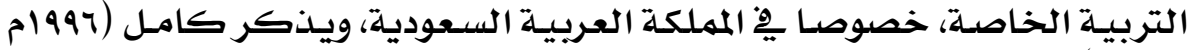

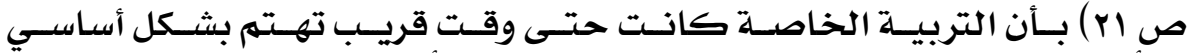

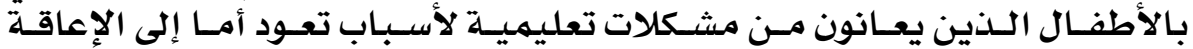

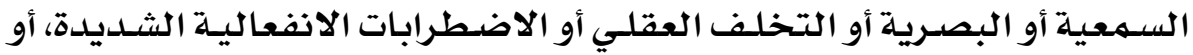

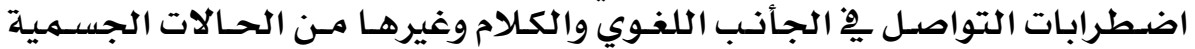

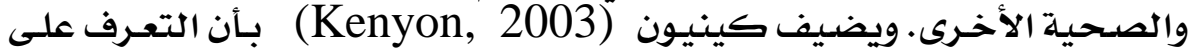

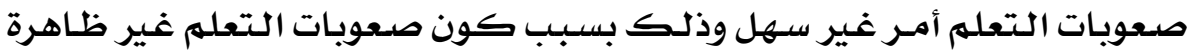

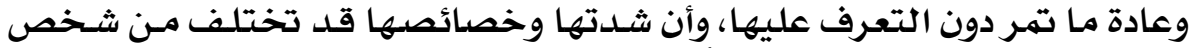

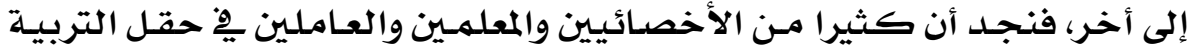

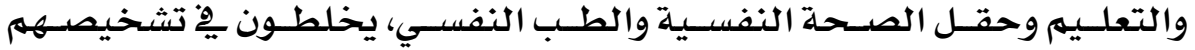

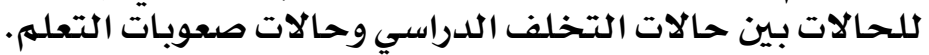

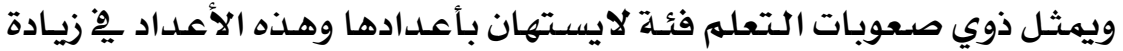

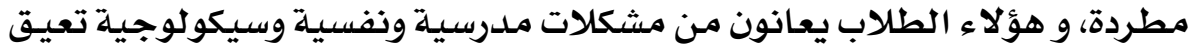

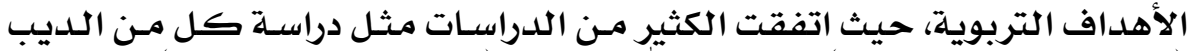

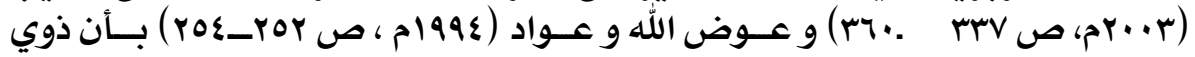

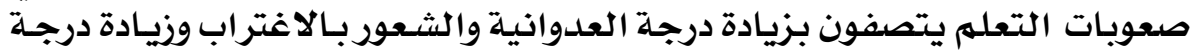

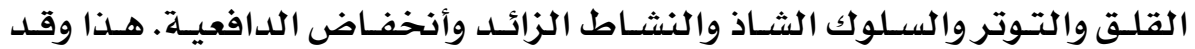

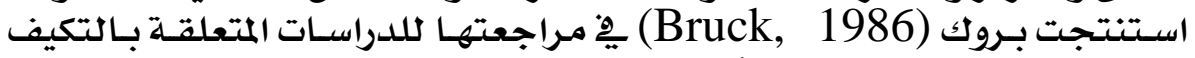

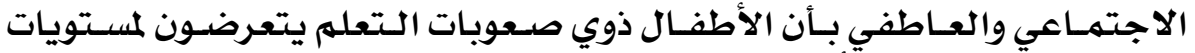

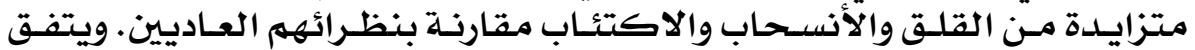

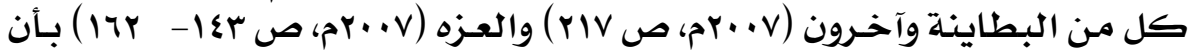

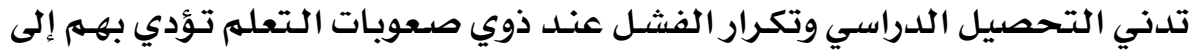

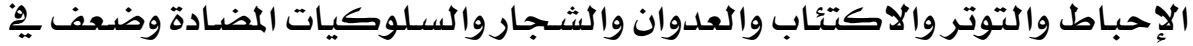

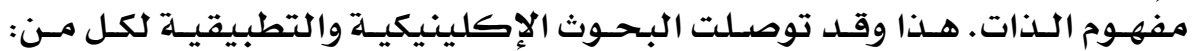

\section{r $q$}




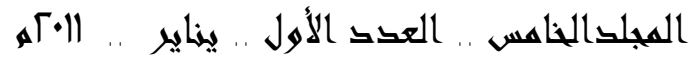

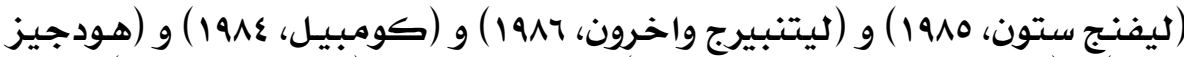

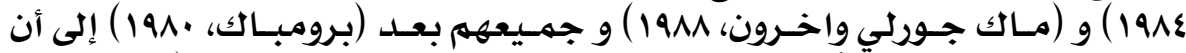

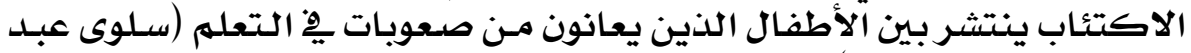

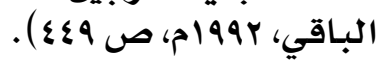

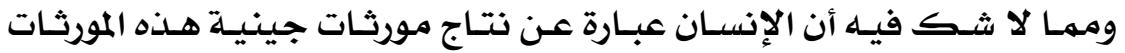

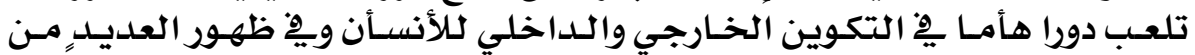

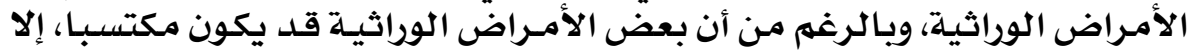

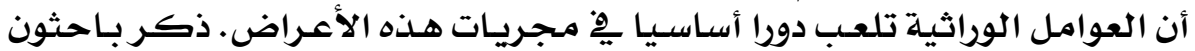

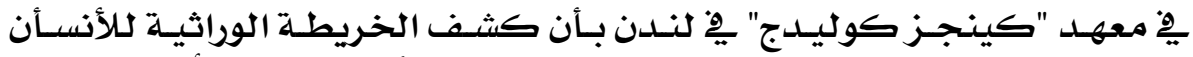

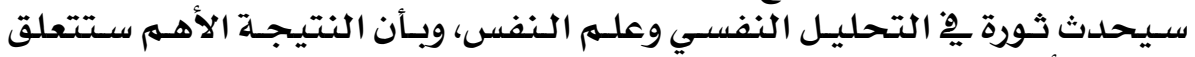

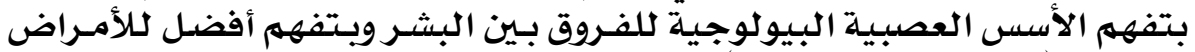

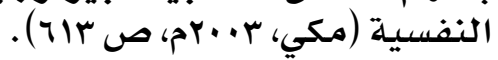

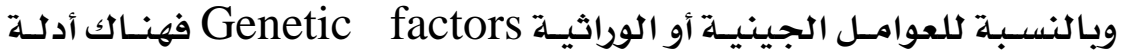

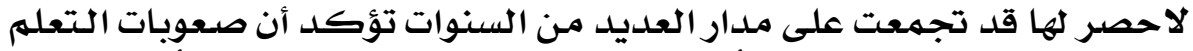

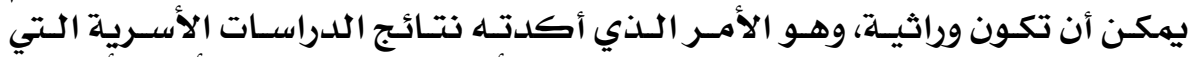

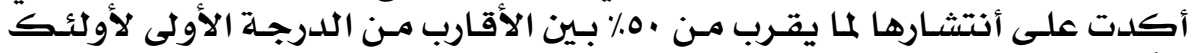

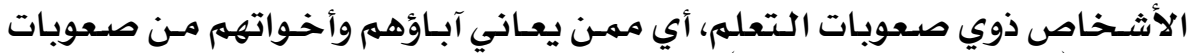

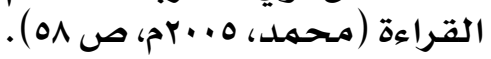

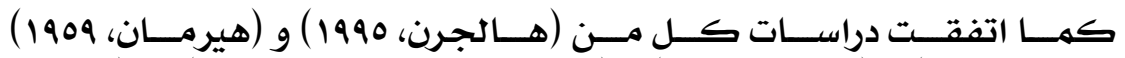

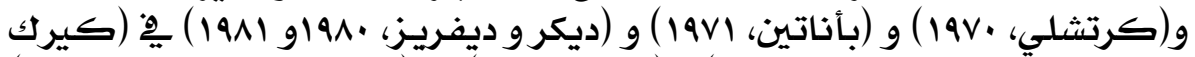

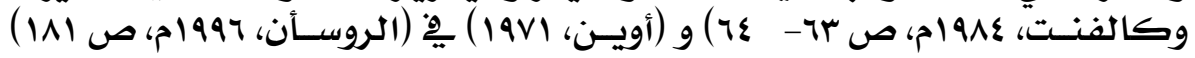

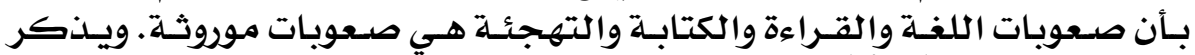

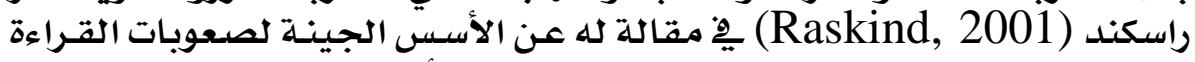

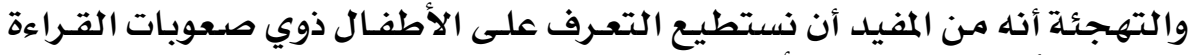

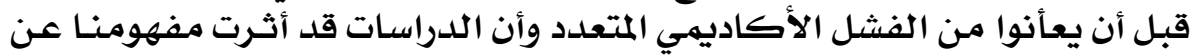

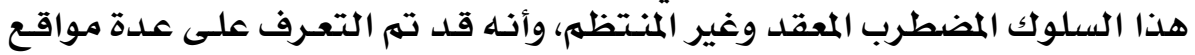

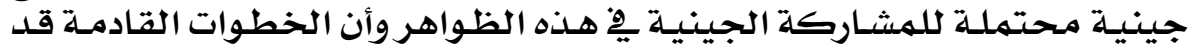

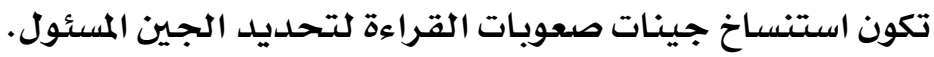

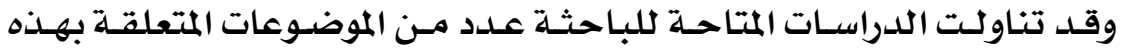

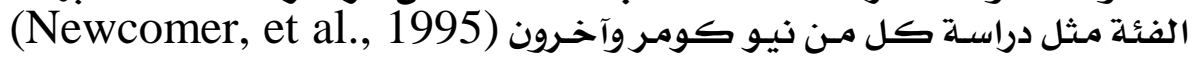

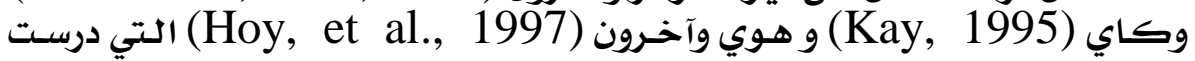

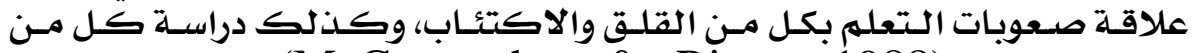

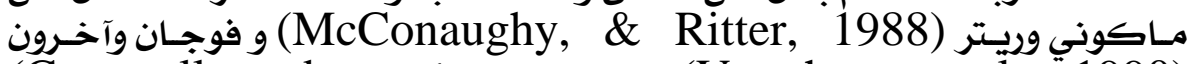
(Cornwall and و كورنويـل ووأبـأودين (Voughn, et al., 1990) (التي تناولت علاقة صعوبات التعلهم بالسلونك العدواني. Bawden, 1992)

\section{Y०.}




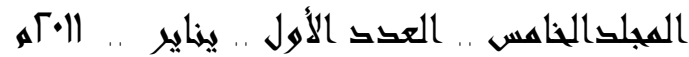

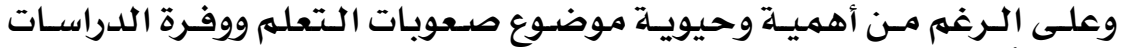

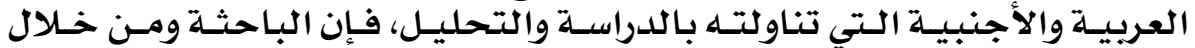

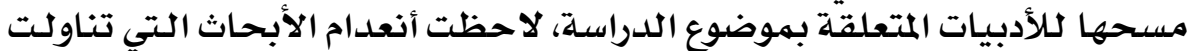

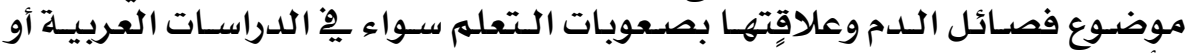

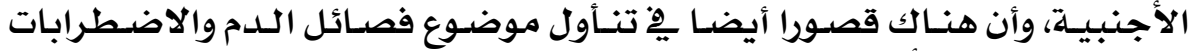

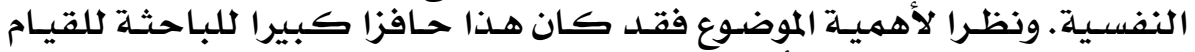

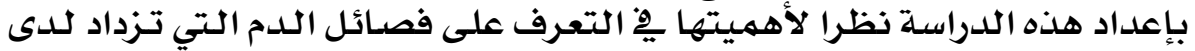

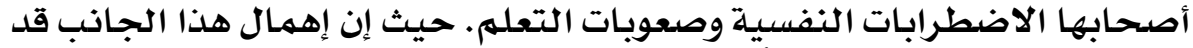

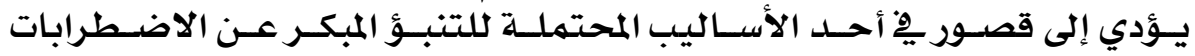

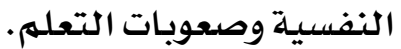

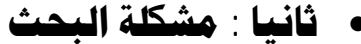

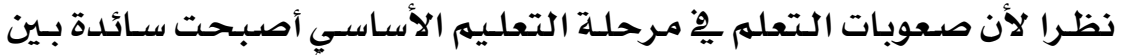

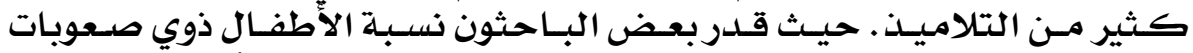

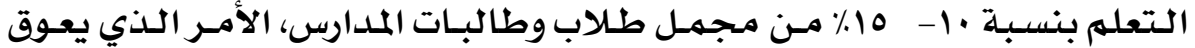

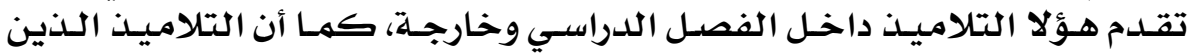

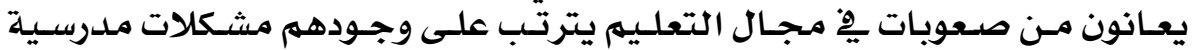

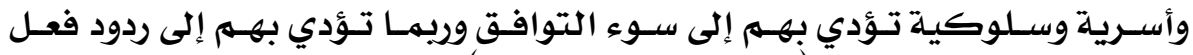

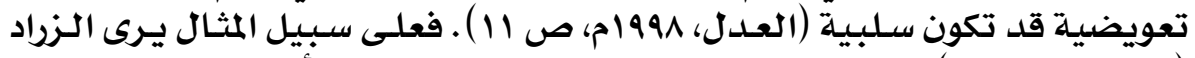

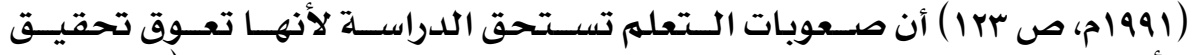

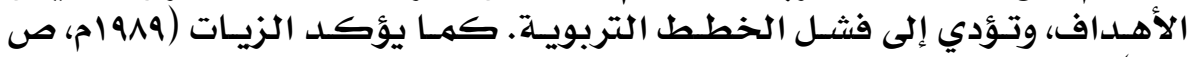

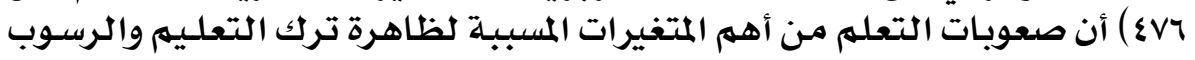

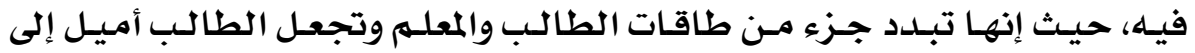

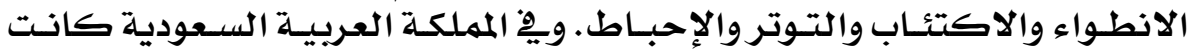

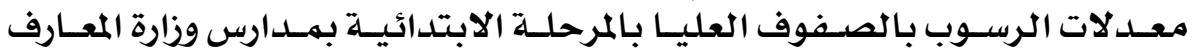

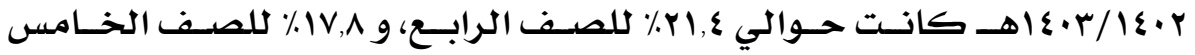

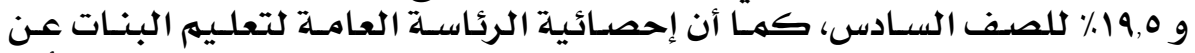

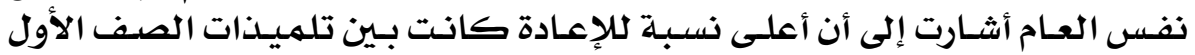

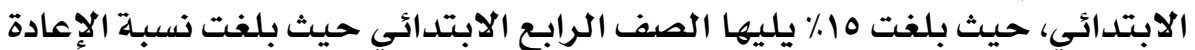

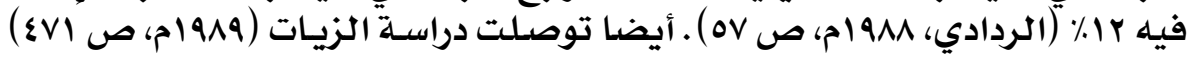

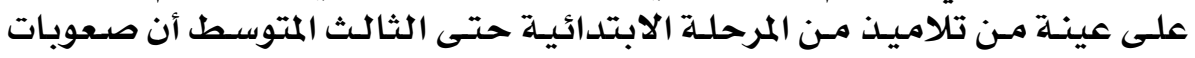

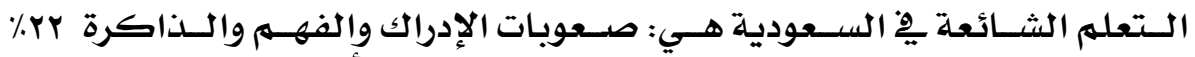

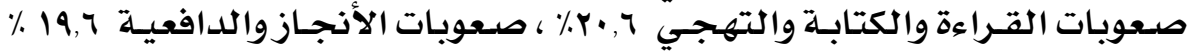

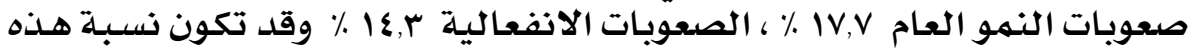

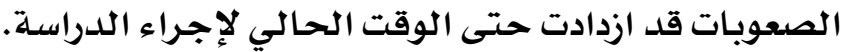

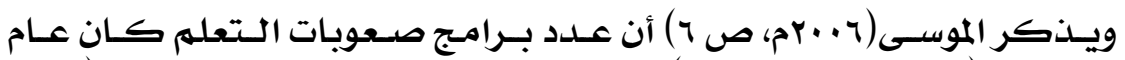

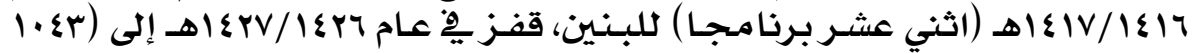

\section{Y 1}




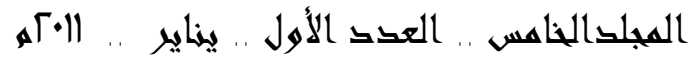

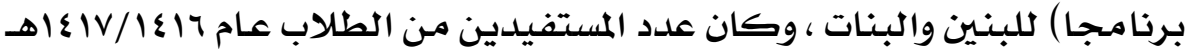

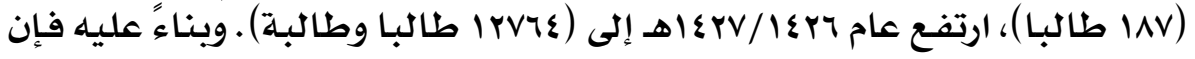

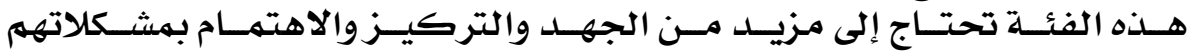

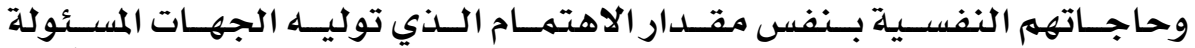

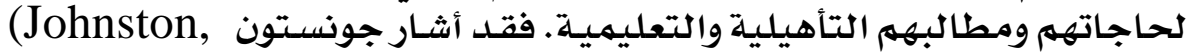

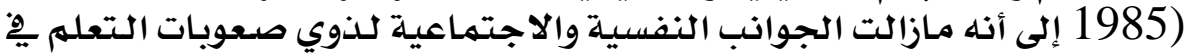

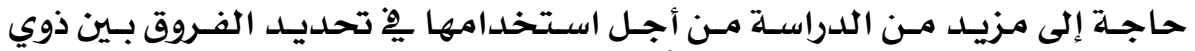

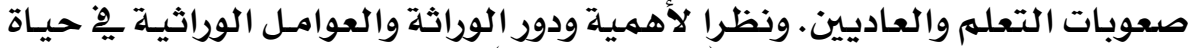

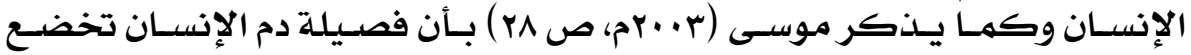

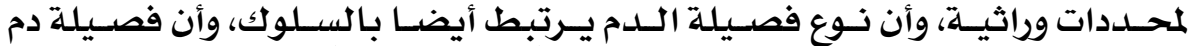

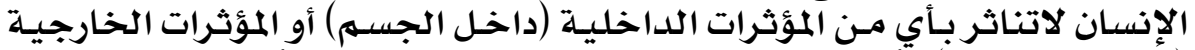

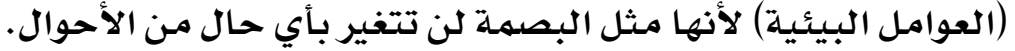

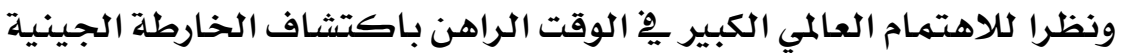

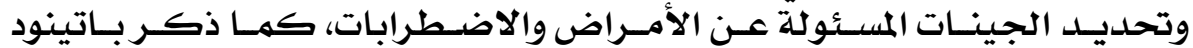

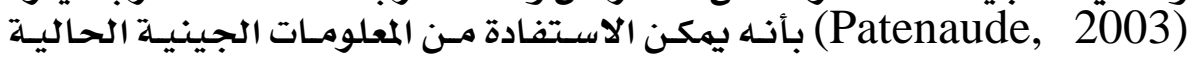

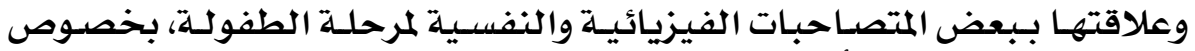

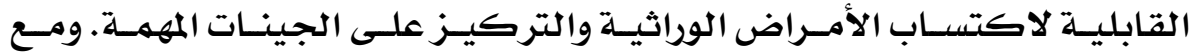

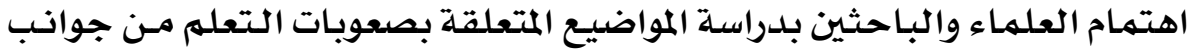

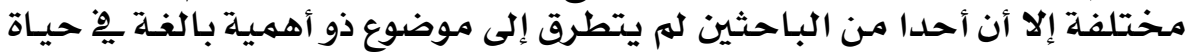

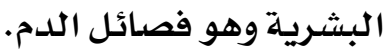

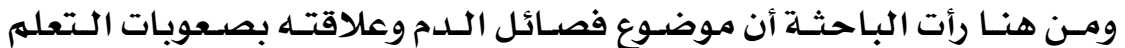

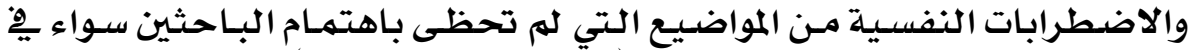

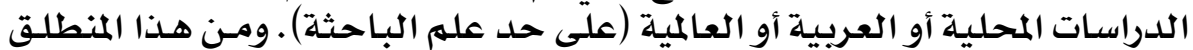

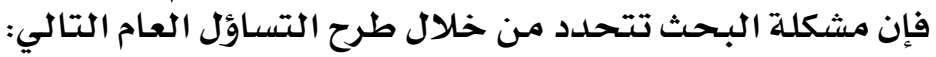

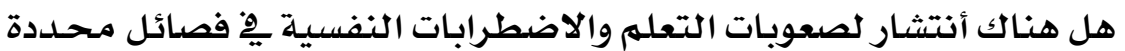

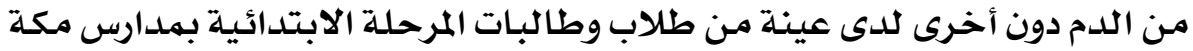

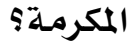

ويتفرع عن هذا التساؤل العام عدد من الأسئلة الفرعية:

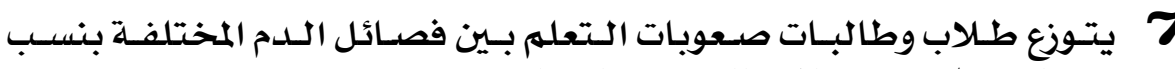

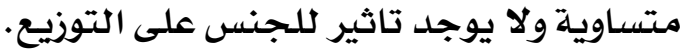

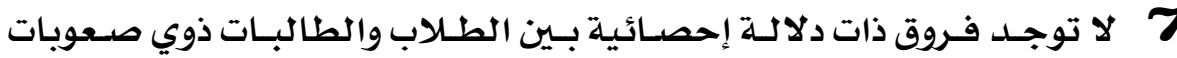

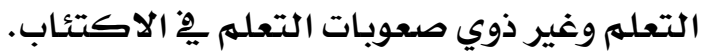

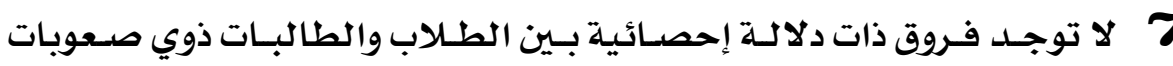

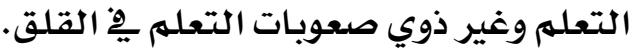

\section{$Y \odot Y$}




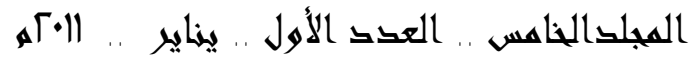

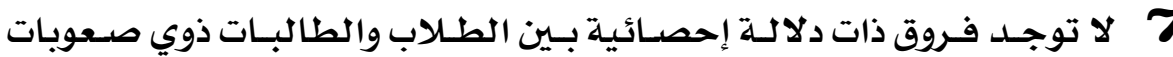

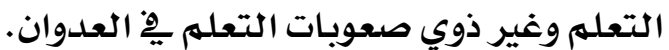

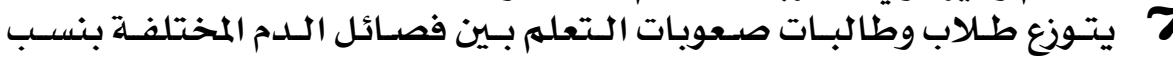

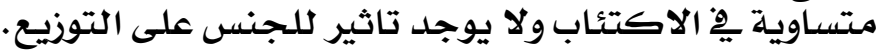

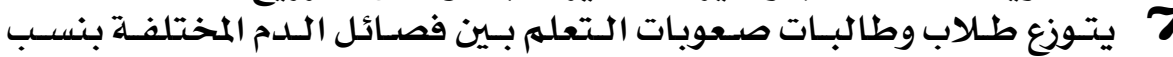

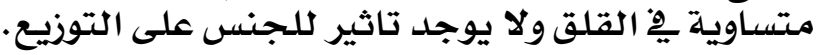

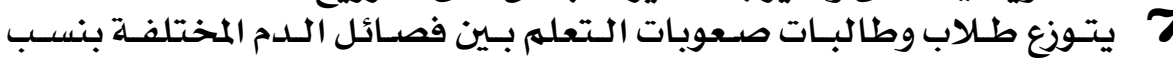

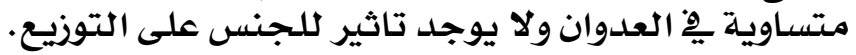

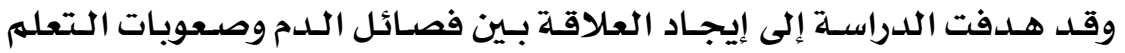

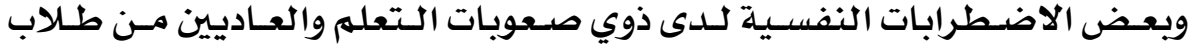

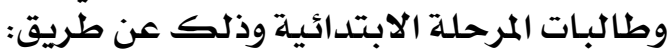

7

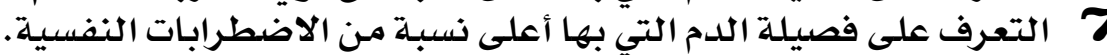

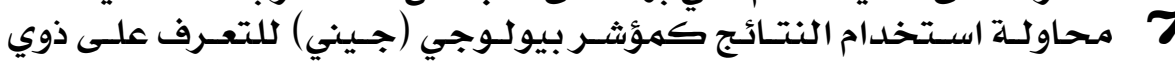

صعوبات التعلهم.

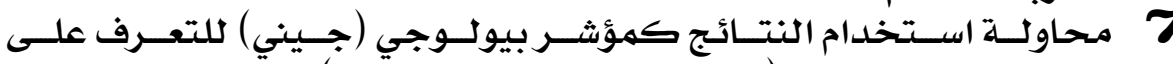

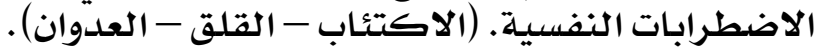

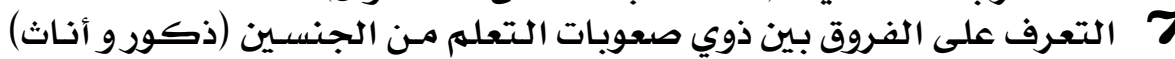

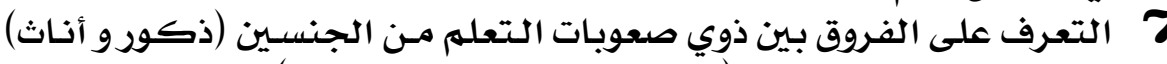

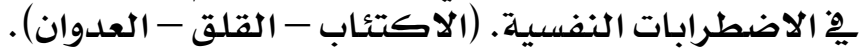

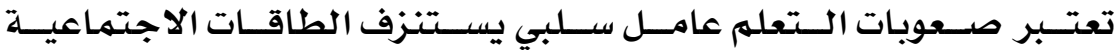

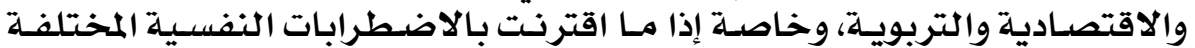

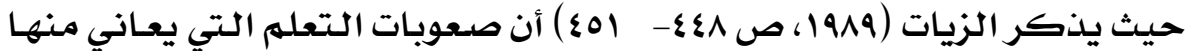

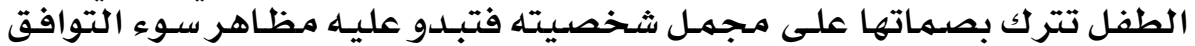

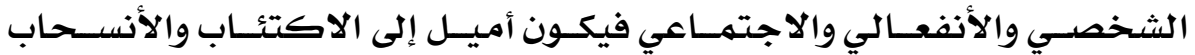

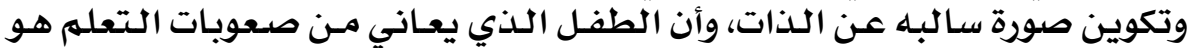

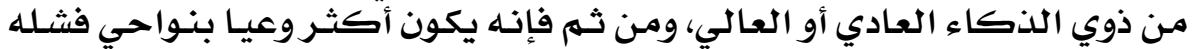

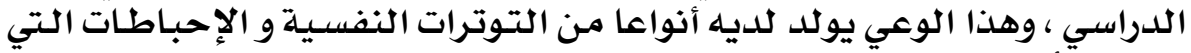

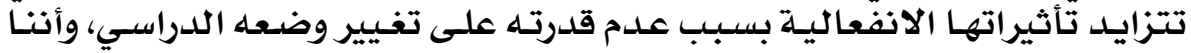

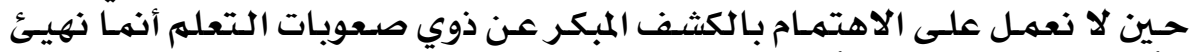

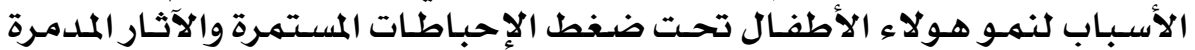

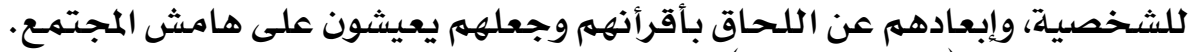

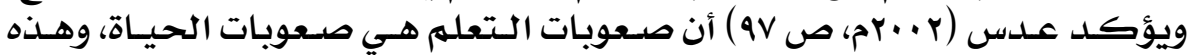

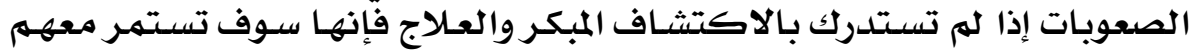

\section{$Y \bullet Y$}


المجلى للخاهس .. العك الأول .. يناير .. الآم

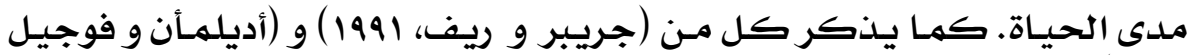

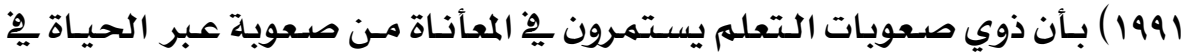

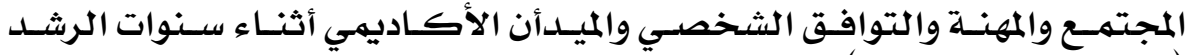

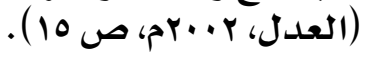

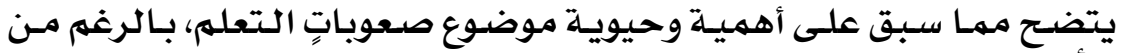

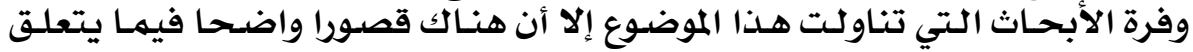

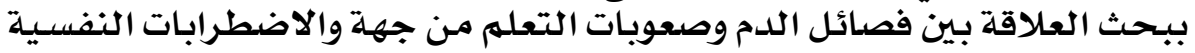

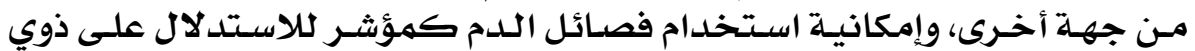

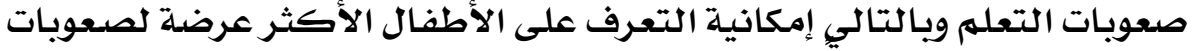

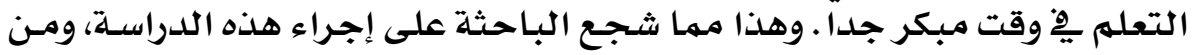

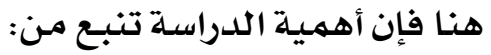

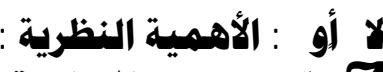

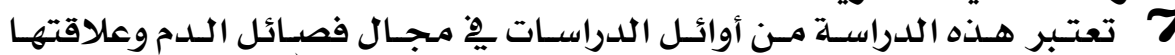

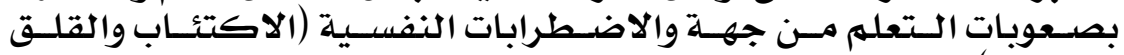

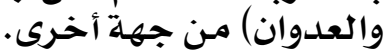

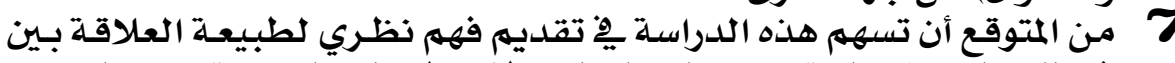

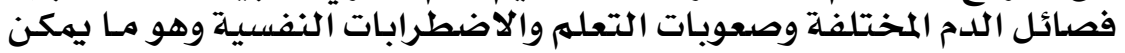

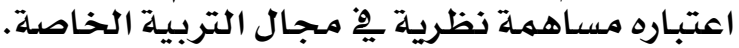
7 المستقبلية.

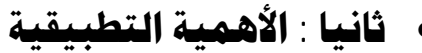

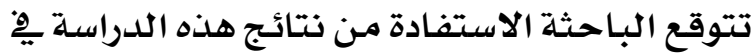

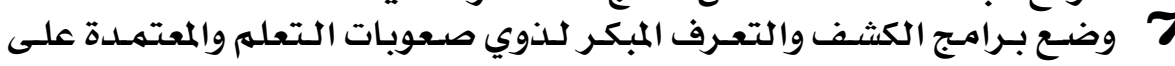
فصائلِ الدمام.

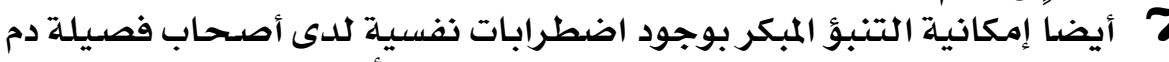

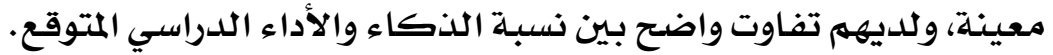
7

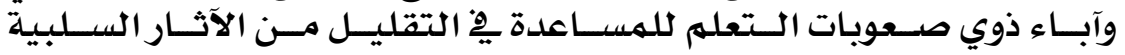

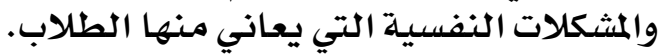

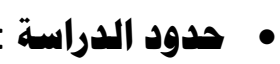

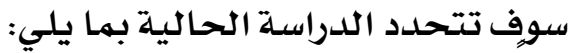

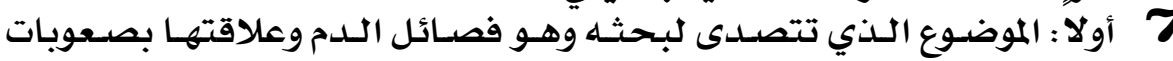

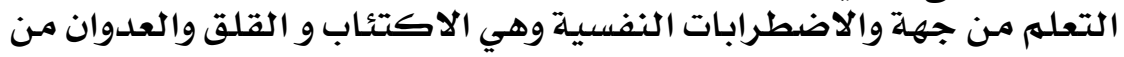
جهانة أخرى التمن جمي

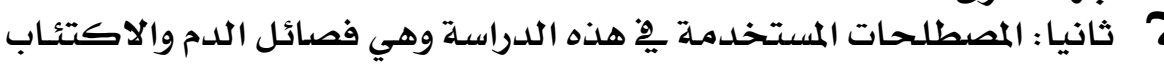
والقلق والعدوان وصعوبات التعلمه.

\section{$Y \odot \varepsilon$}




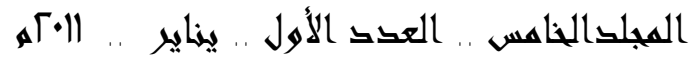

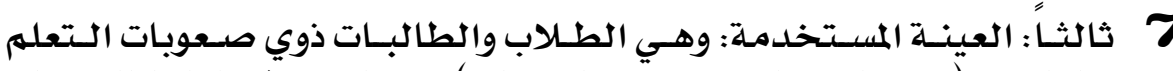

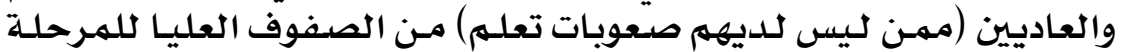

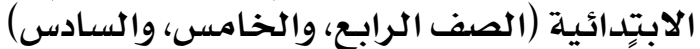

7

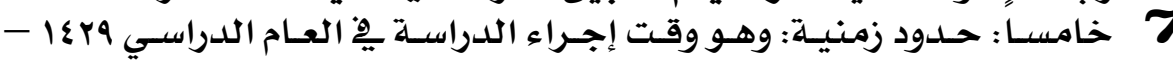

.

7

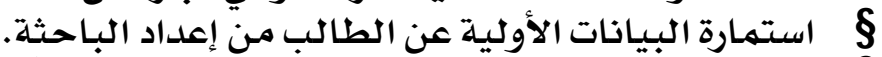

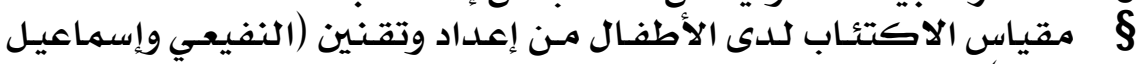

( ү....

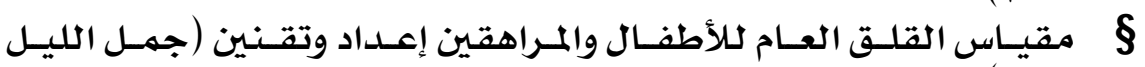

(r. . o

مقياس السلوك العدواني لدى الأطفال إعداد (أمال باظة، د ت م

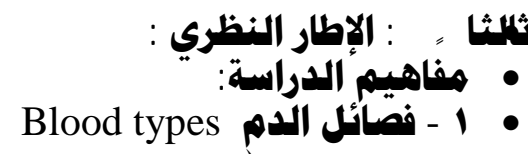

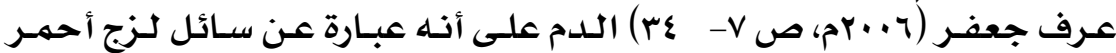

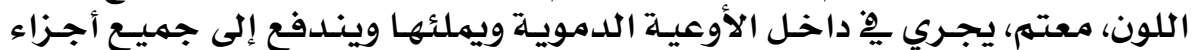

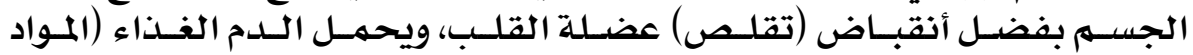

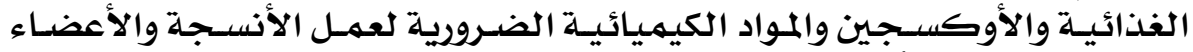

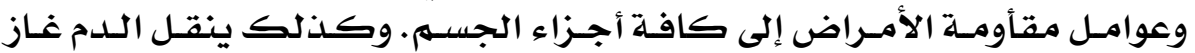

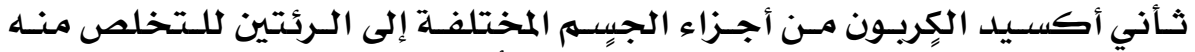

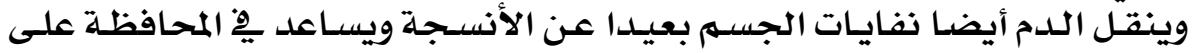

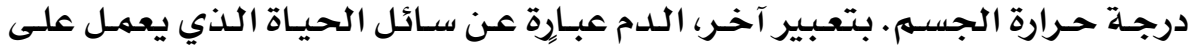

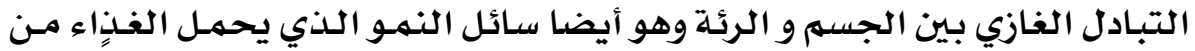

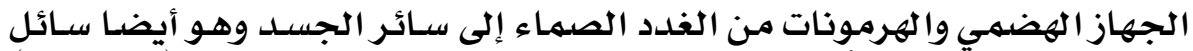

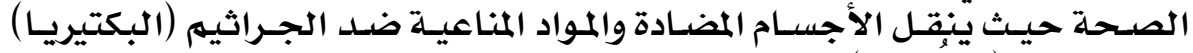

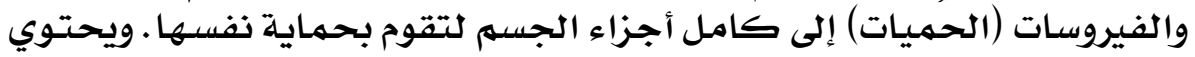

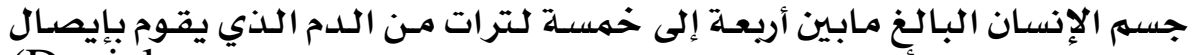

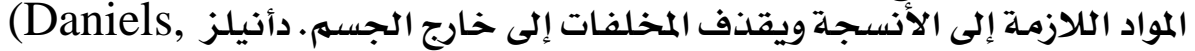
.2002)

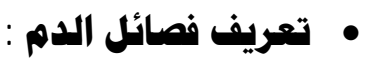

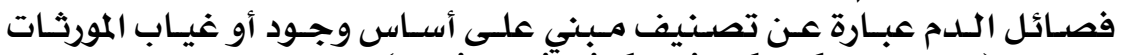

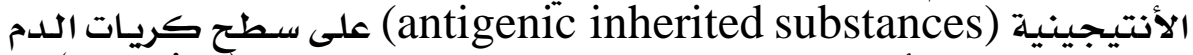

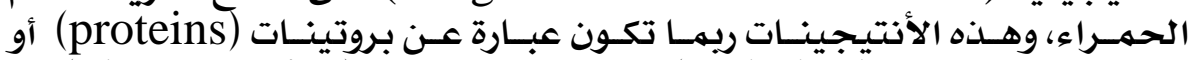

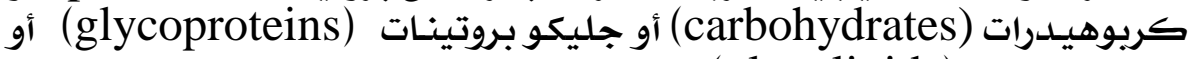

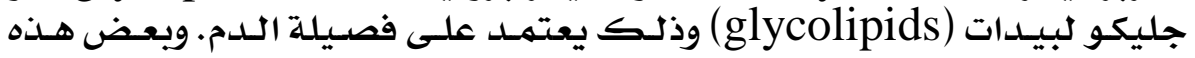

\section{Y००}

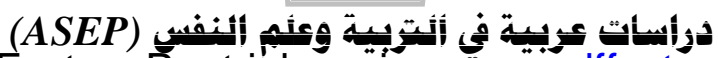

PDF created with pdfFactory Pro trial version www.pdffactory.com 


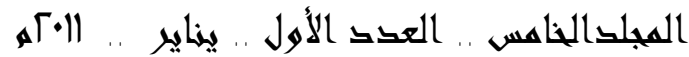

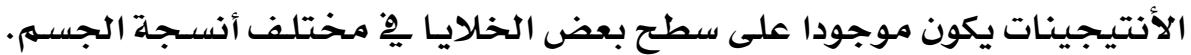

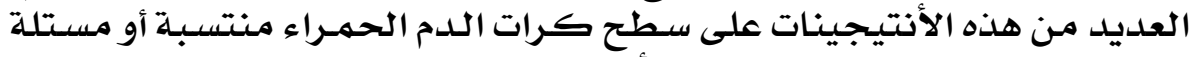

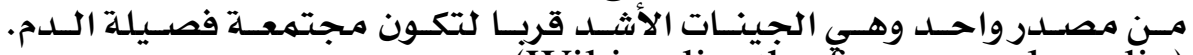
.(Wikipedia, the free encyclopedia)

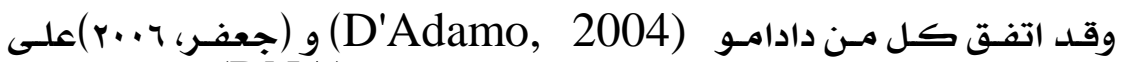

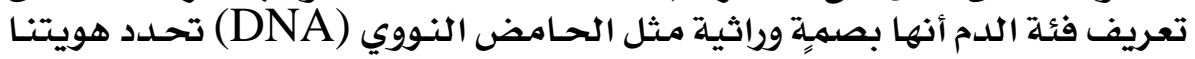

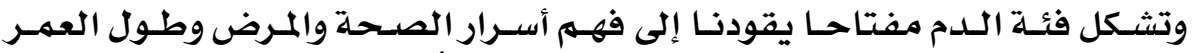

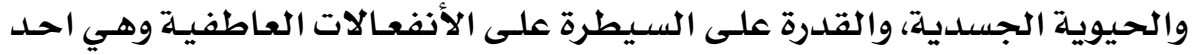

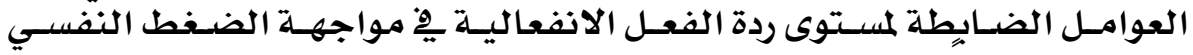

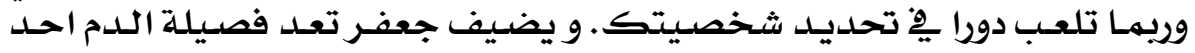

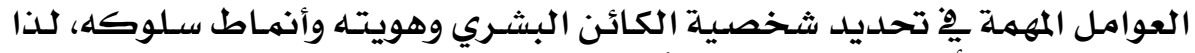

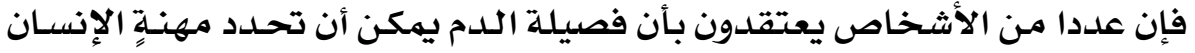

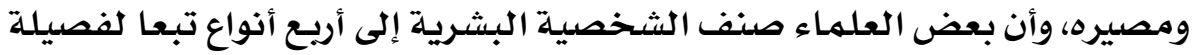

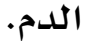

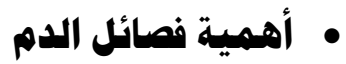

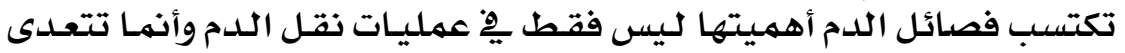

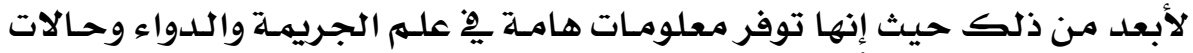

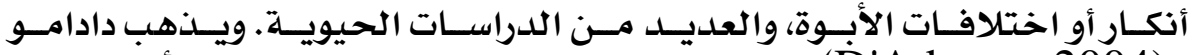

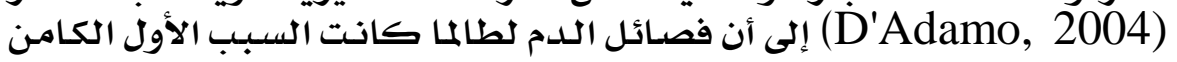

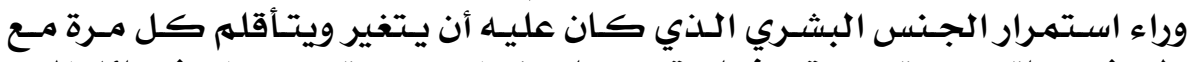

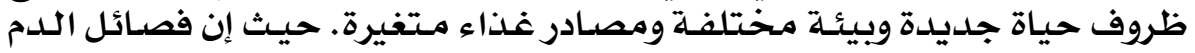

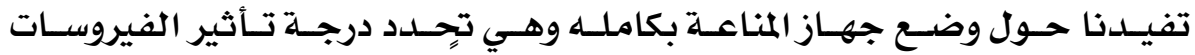

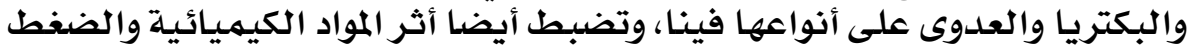

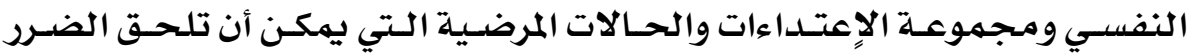

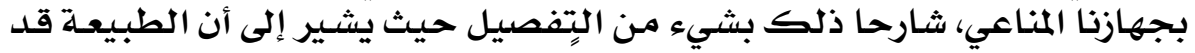

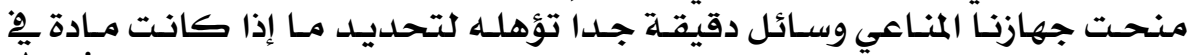

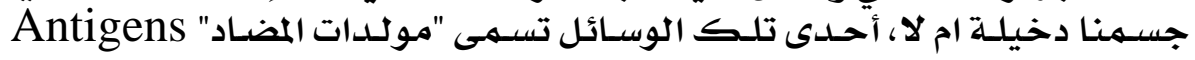

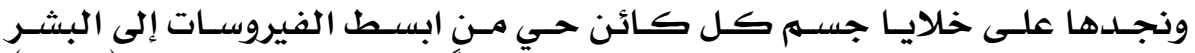

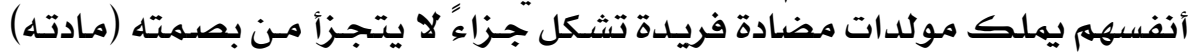

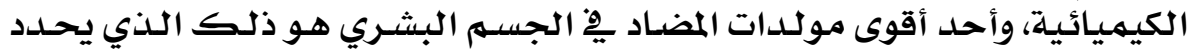

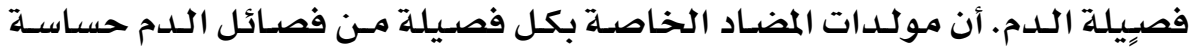

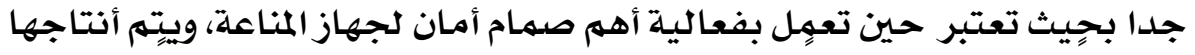

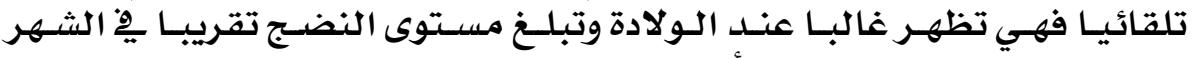

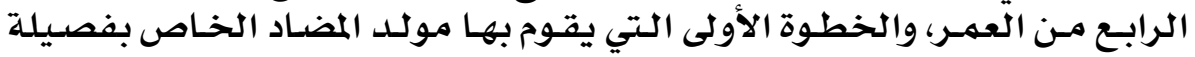

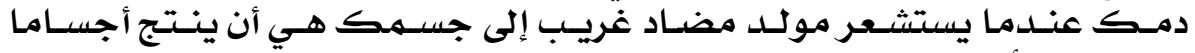

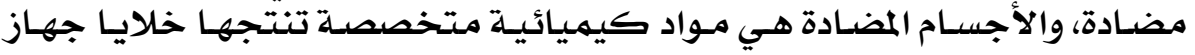

\section{Y०}




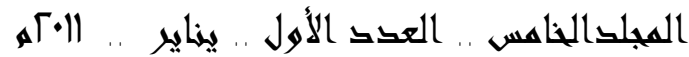

المناعة، هدفها الالتصاق بمولد المضاد الدخيل بغية القضـاء عليـه، وتظل المعـارك إنك

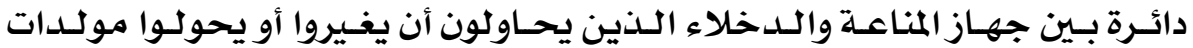

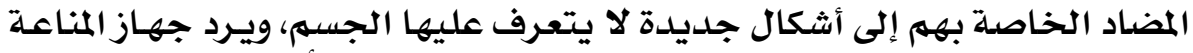

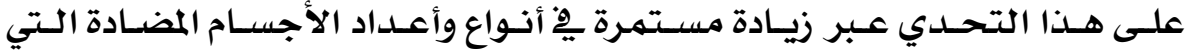

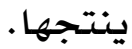

\section{• لمة تاريخية عن علاقة فصائل الدم بالشخصية:}

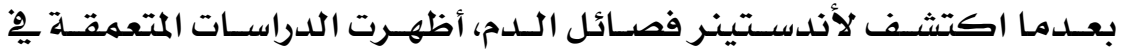

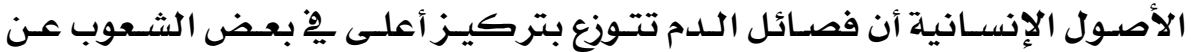

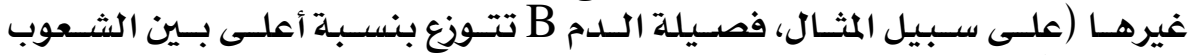

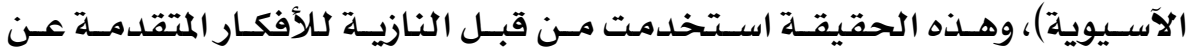

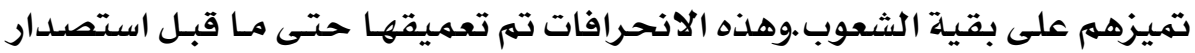

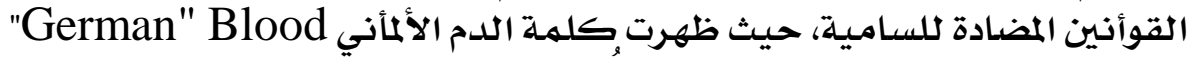

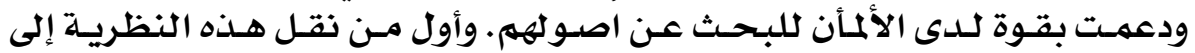

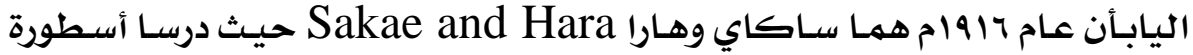

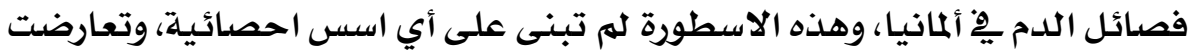

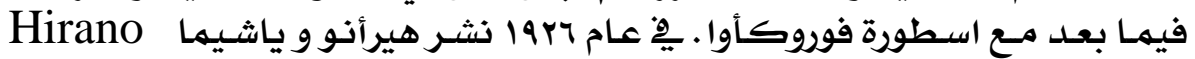
and Yashima

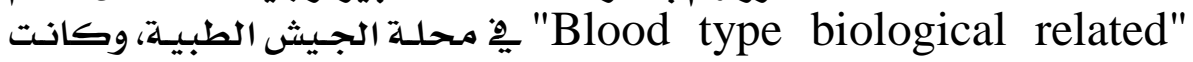

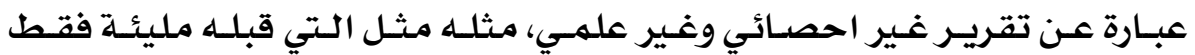

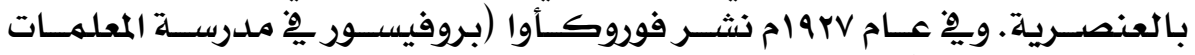

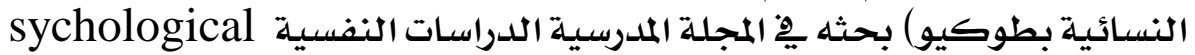

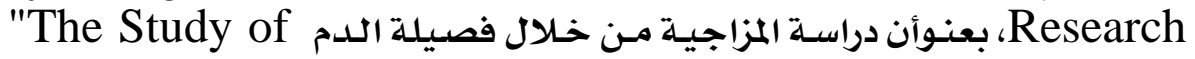
هemperament Through Blood Type"

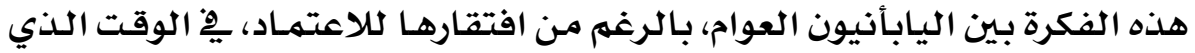

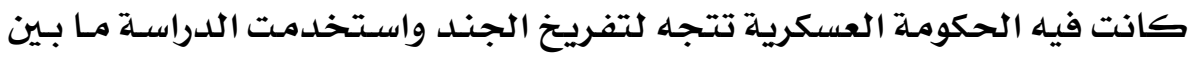

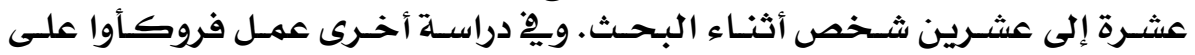

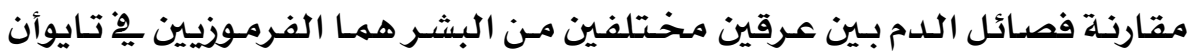

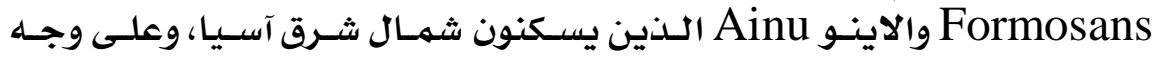

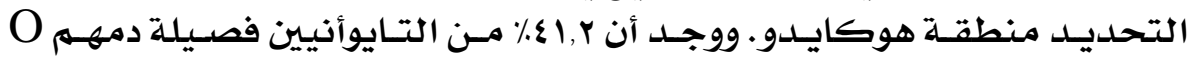

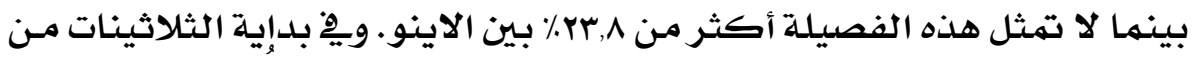

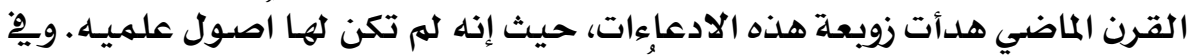

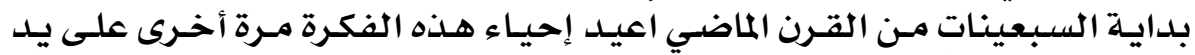

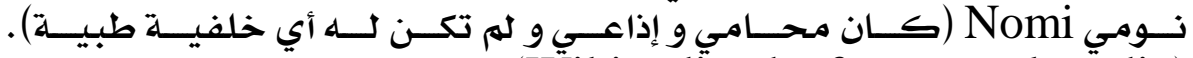
(Wikipedia, the free encyclopedia)

\section{$Y \odot V$}


المجلدالخاهس .. العقد الأول .. يناير .. 1ا•مه

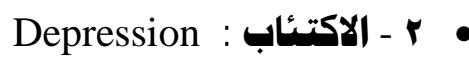

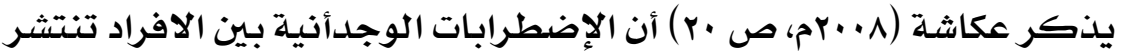

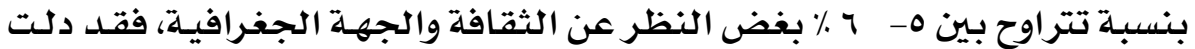

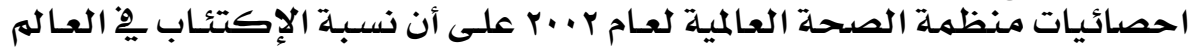

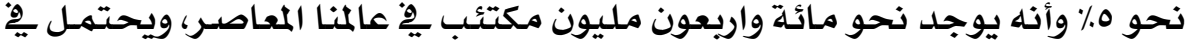

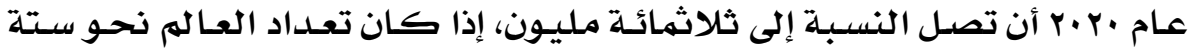

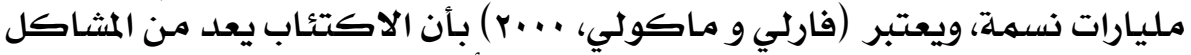

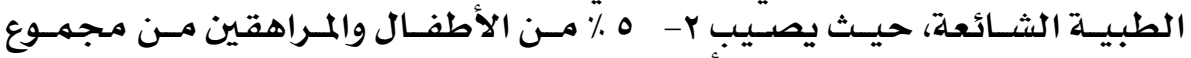

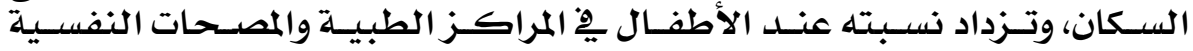

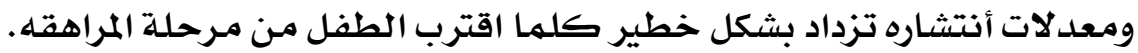

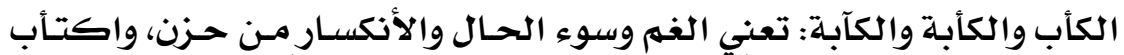

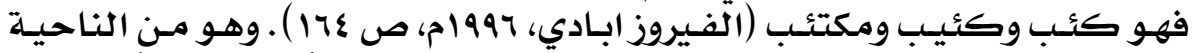

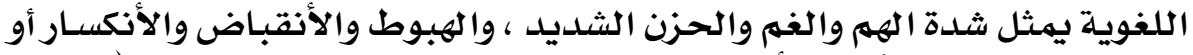
الإعياء والشعور باليأس والأسى. و يؤدي إلى خفض الثض النشاط أو الحيوية (الفيروز

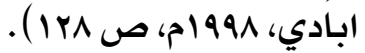

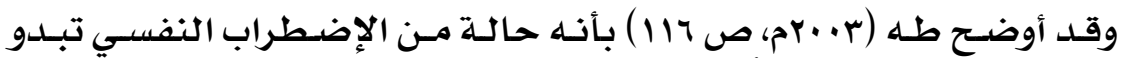

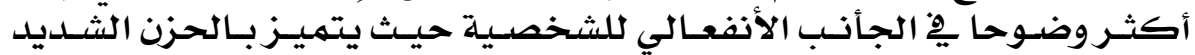

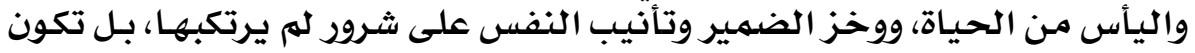

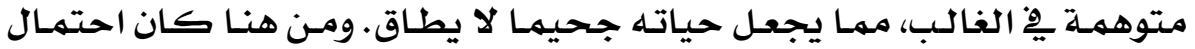

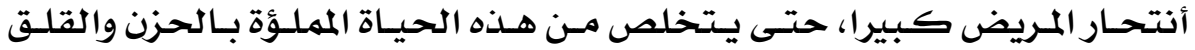

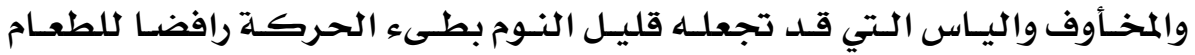

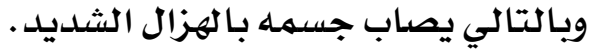

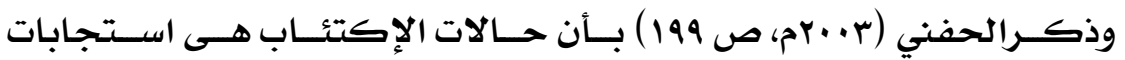

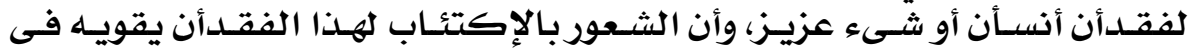

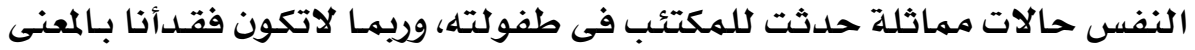

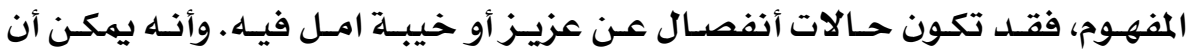

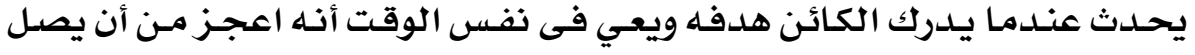
اليه.

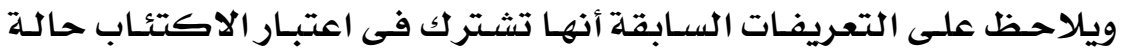

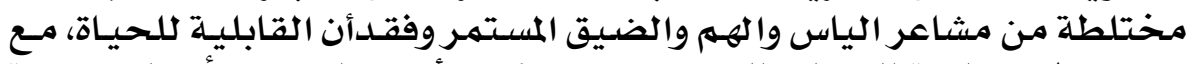

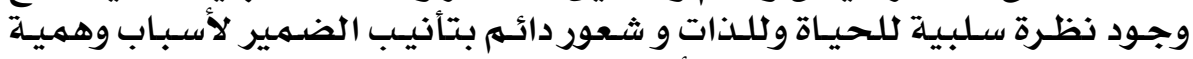
وأنخفاض فى مستوى النشاط والأنتاجية.

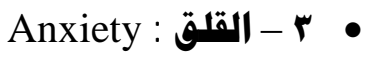

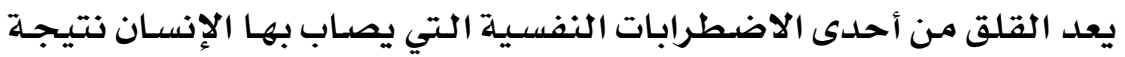

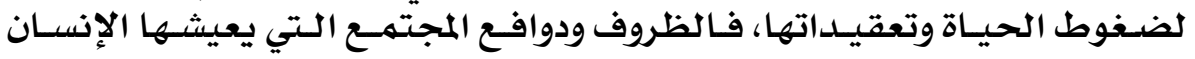

\section{Y०ᄉ}




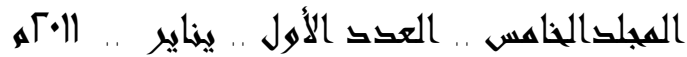

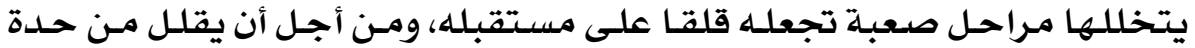

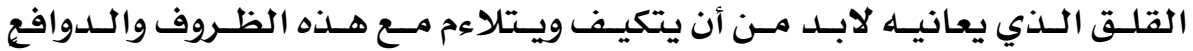

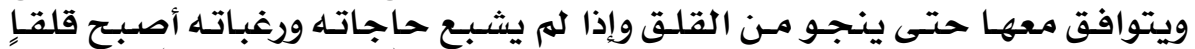

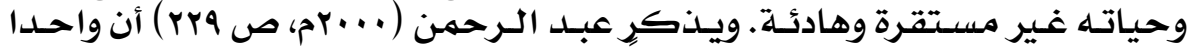

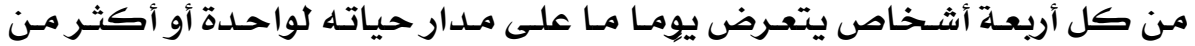

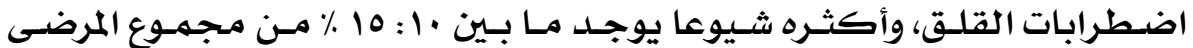

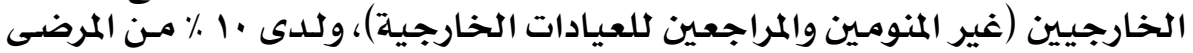

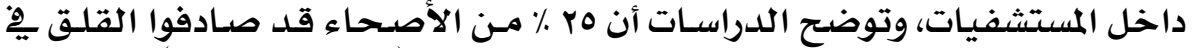

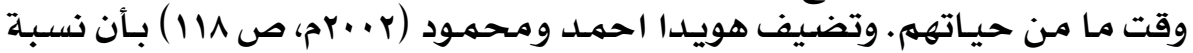

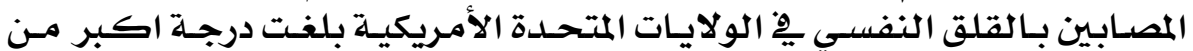

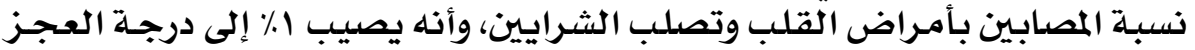

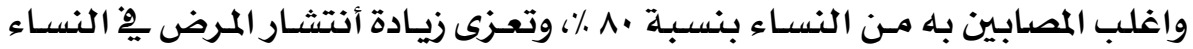

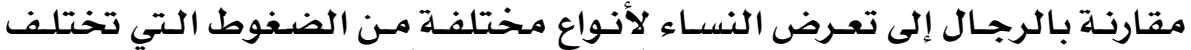

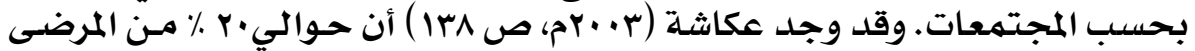

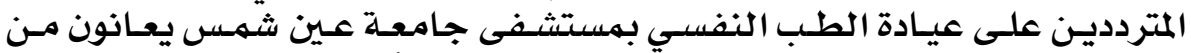

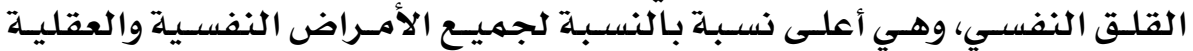
المختلفة.

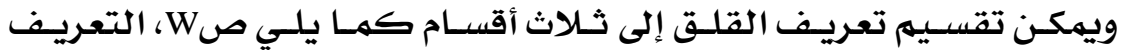

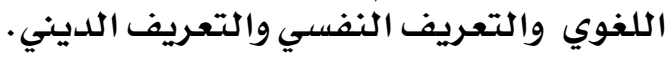
Aggression : • • • • • •

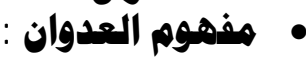

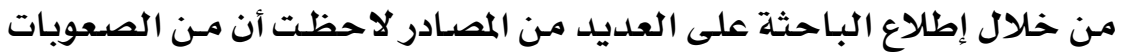

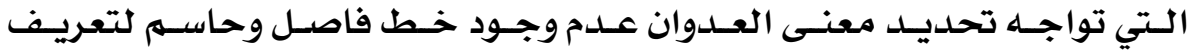

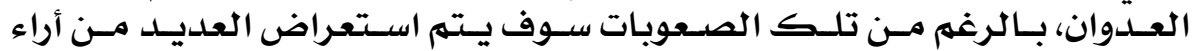

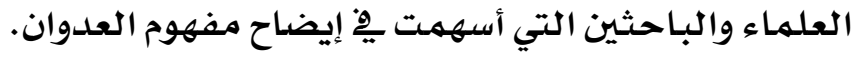

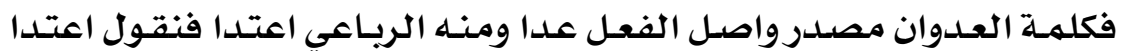

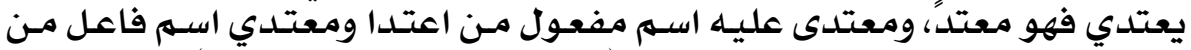

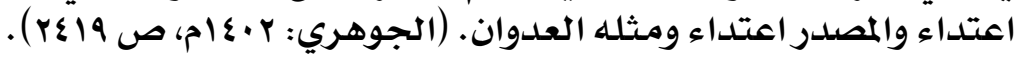

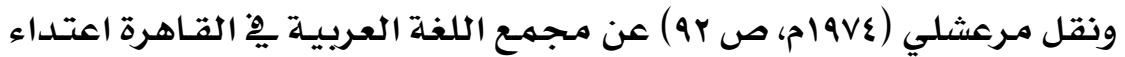

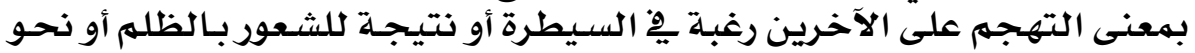

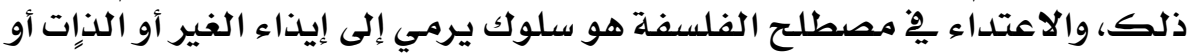

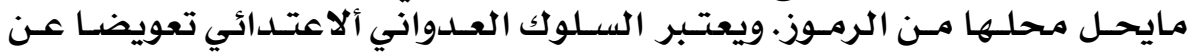
الحرمان الذي يصيب الشخص الشهو المعتدي.

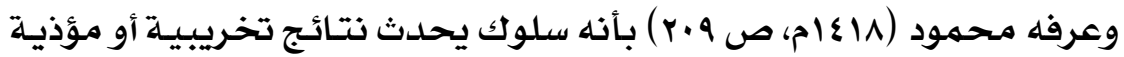

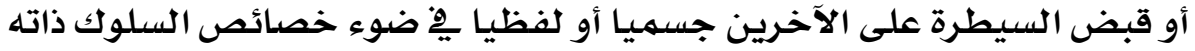

\section{Y०q}




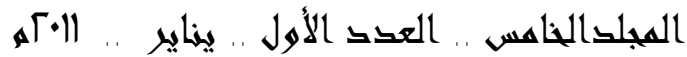

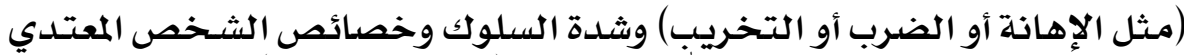

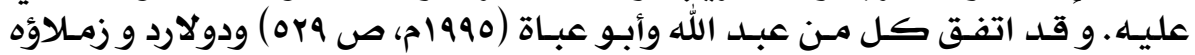

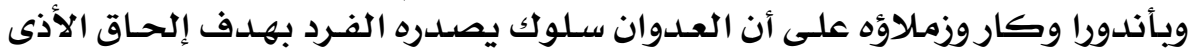

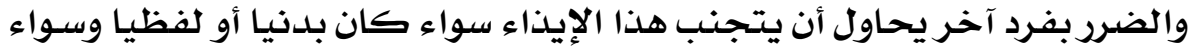

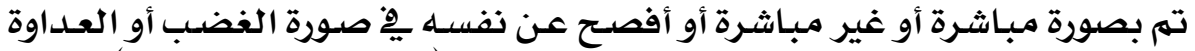

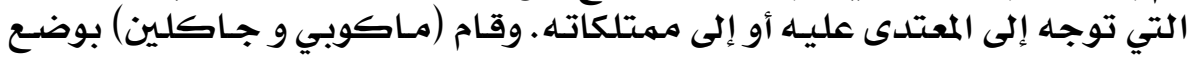

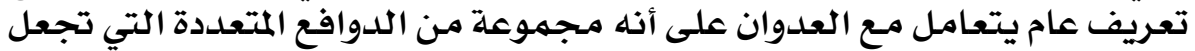

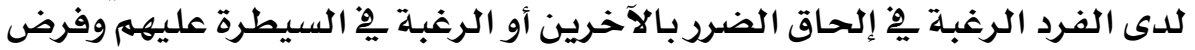

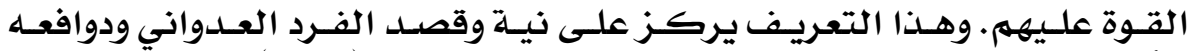

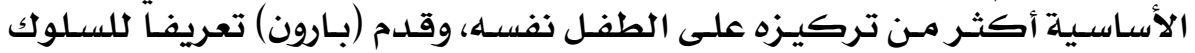

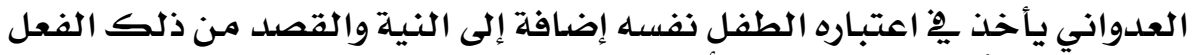

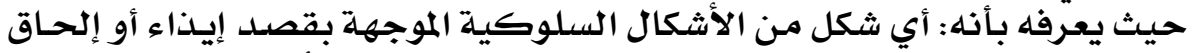

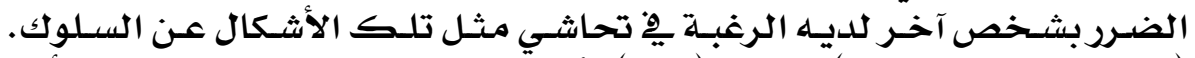

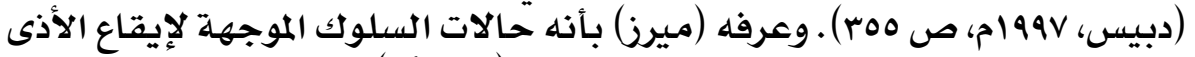

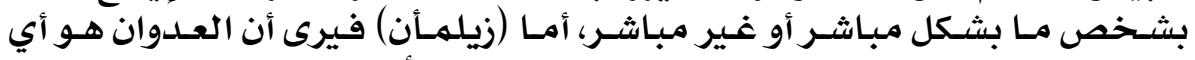

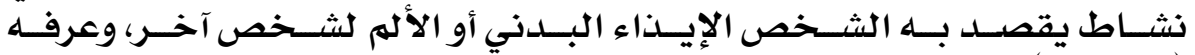

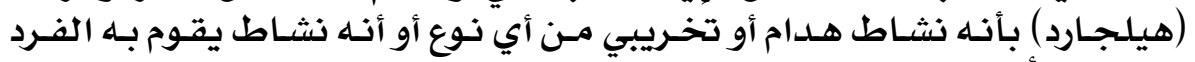

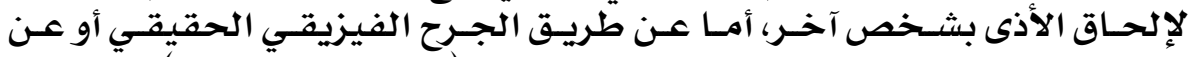

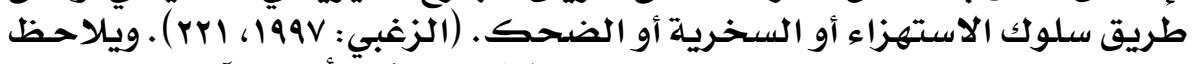

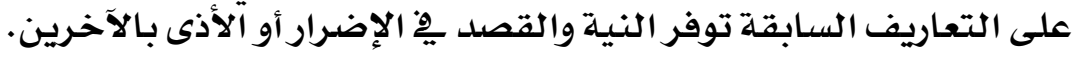

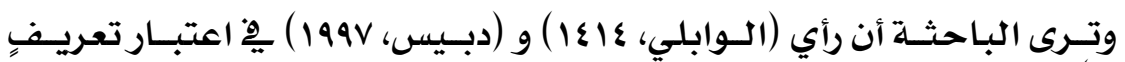

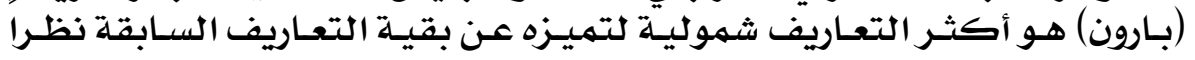

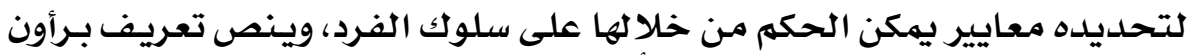

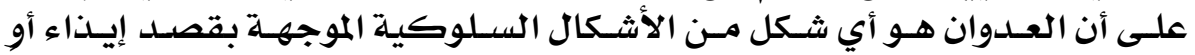

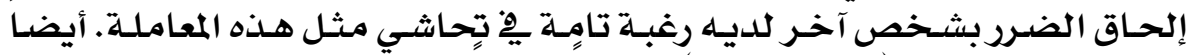

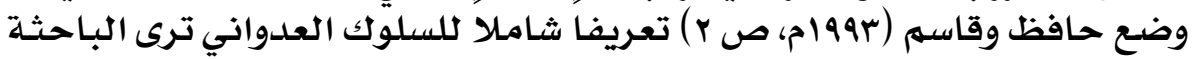

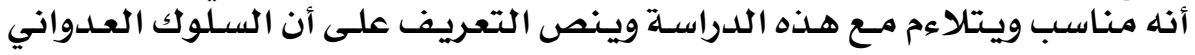

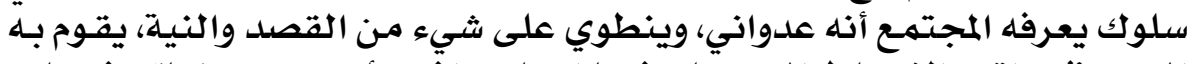

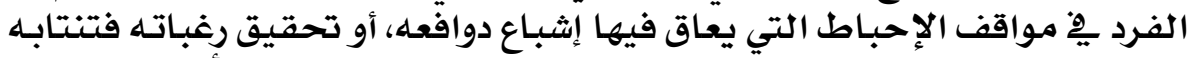

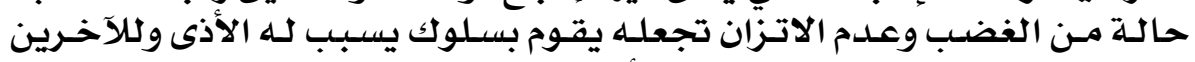

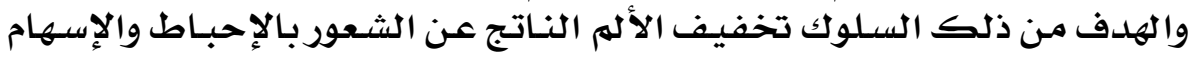

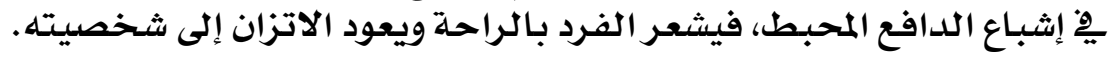

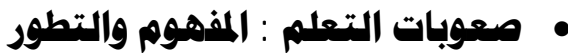

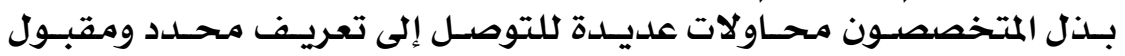

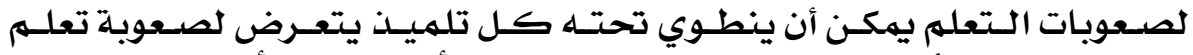

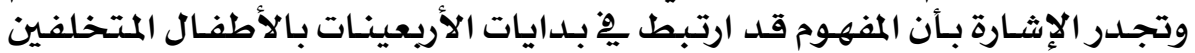

\section{Y}




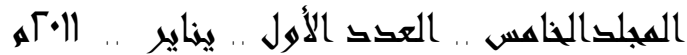

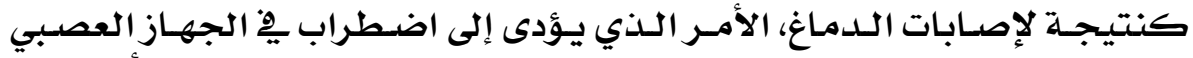

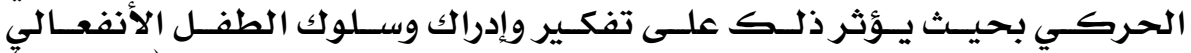

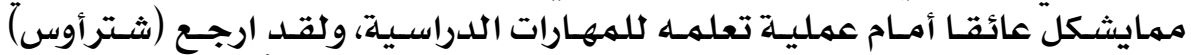

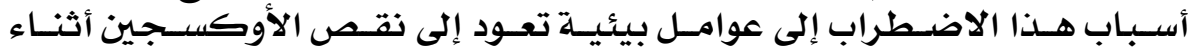

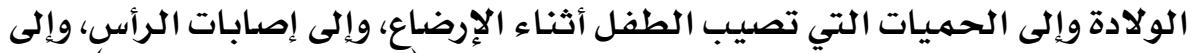

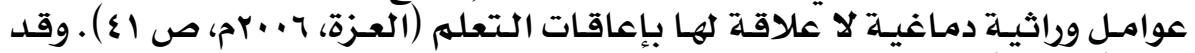

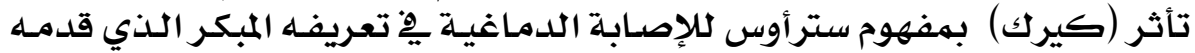

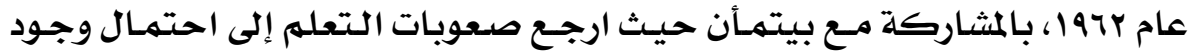

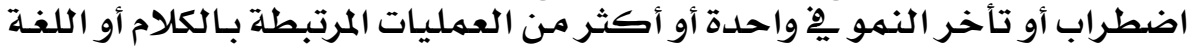

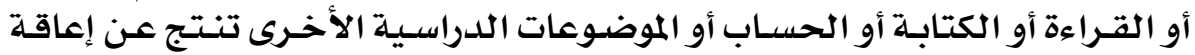

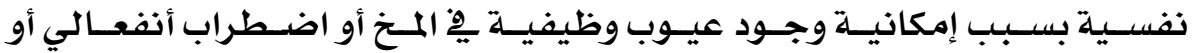

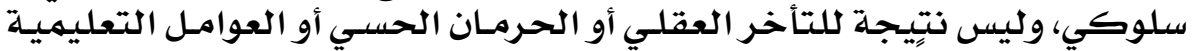

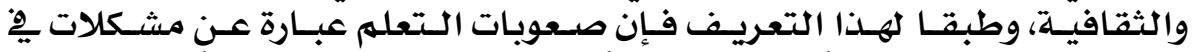

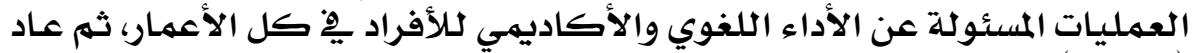

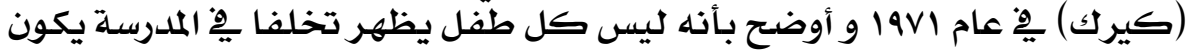

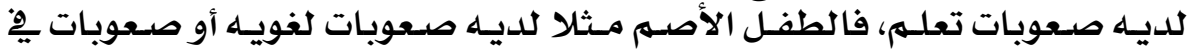

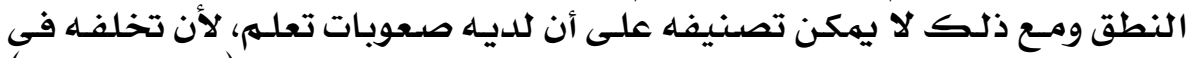

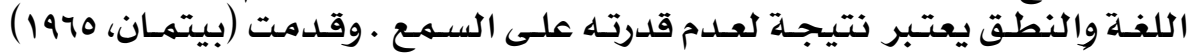

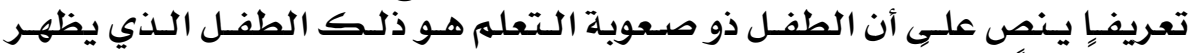

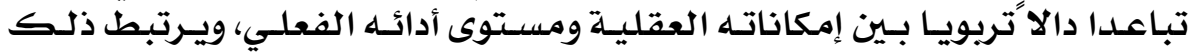

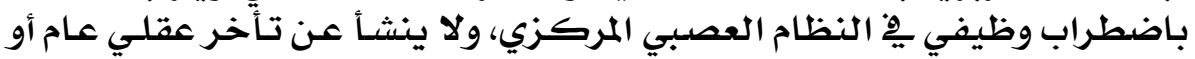

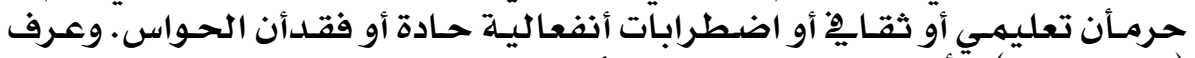

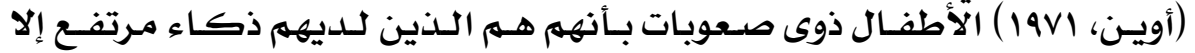

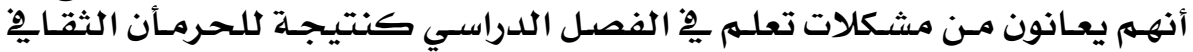

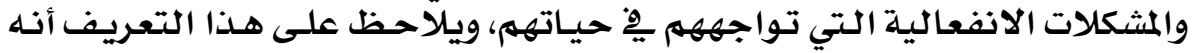

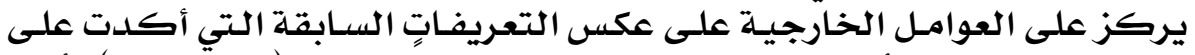

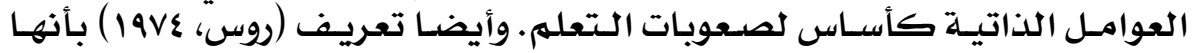

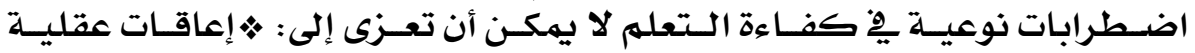

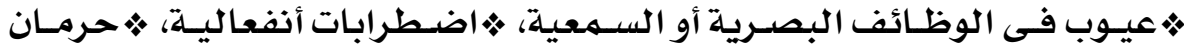
ثقايِّ.

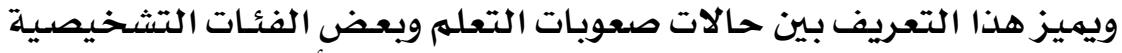

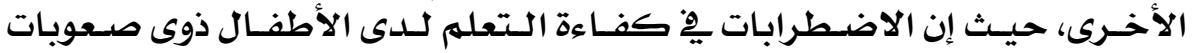

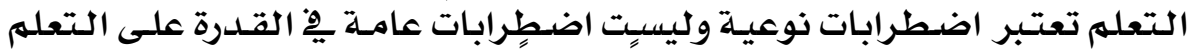

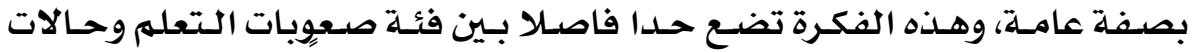

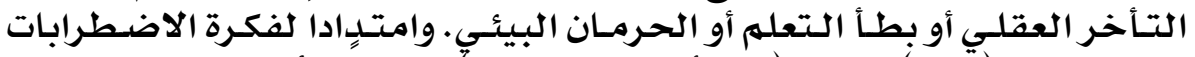

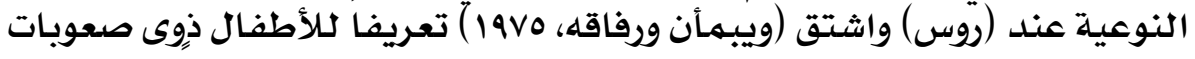

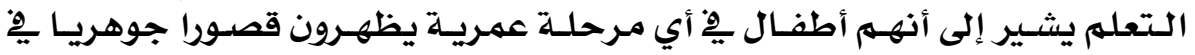

\section{Y}




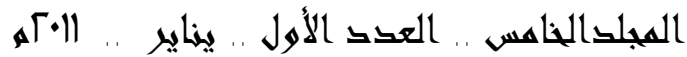

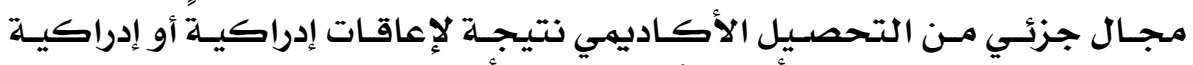

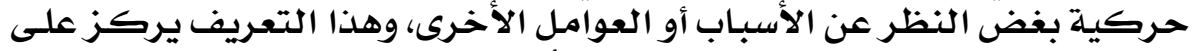

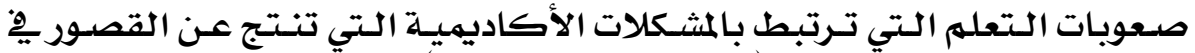

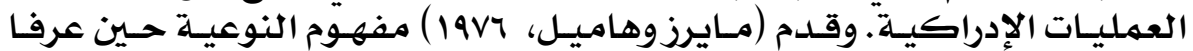

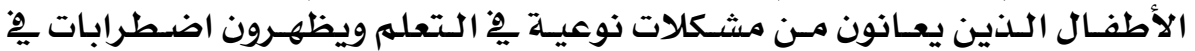

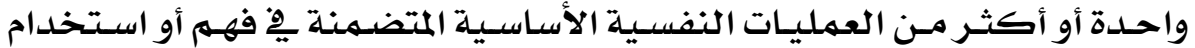

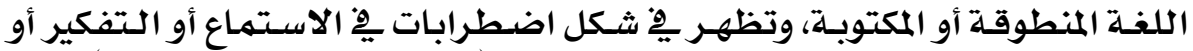

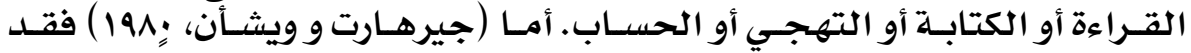

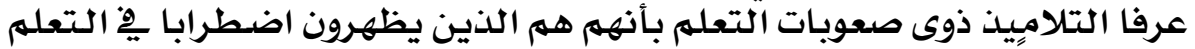

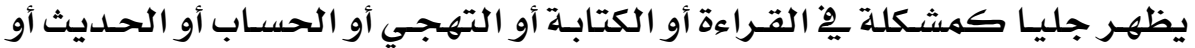

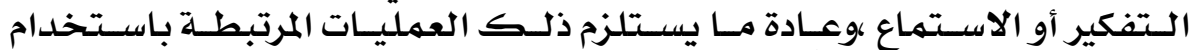

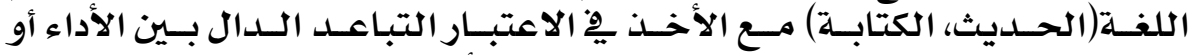

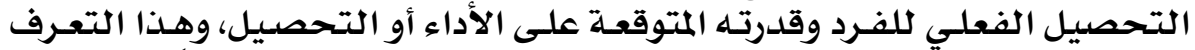

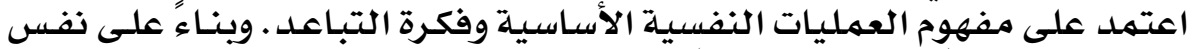

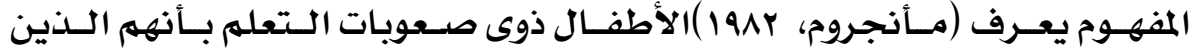

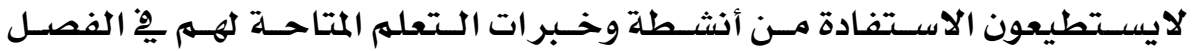

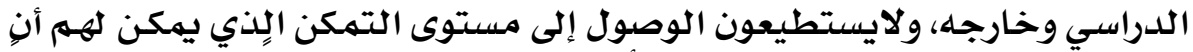

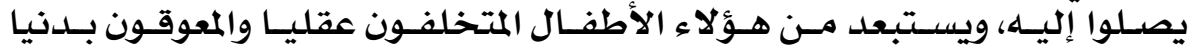

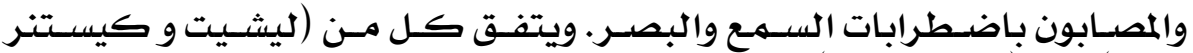

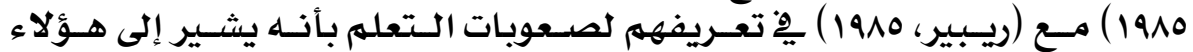

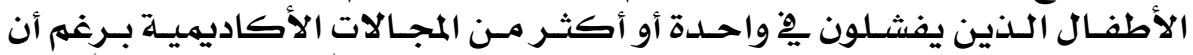

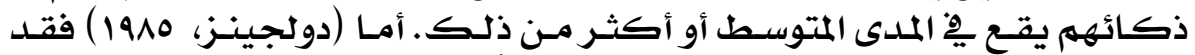

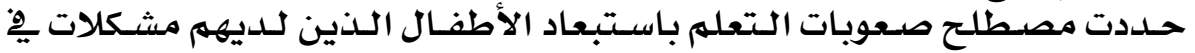

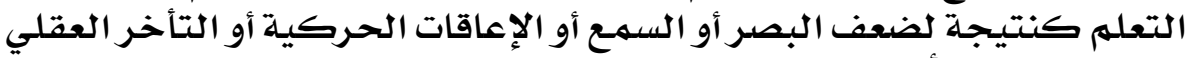

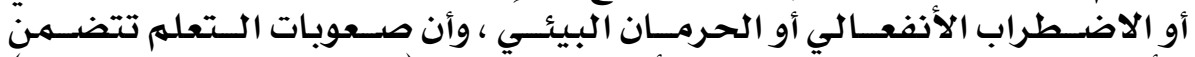

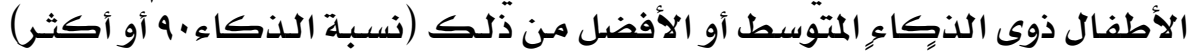

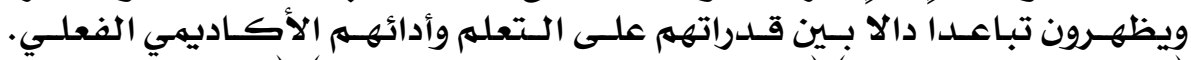

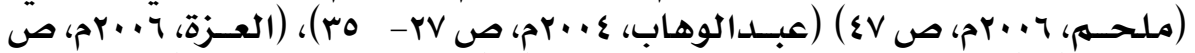

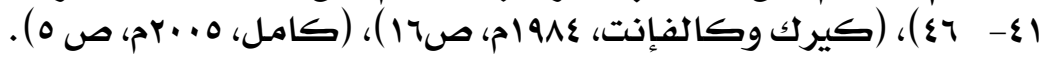

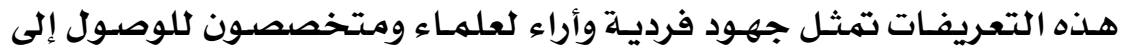

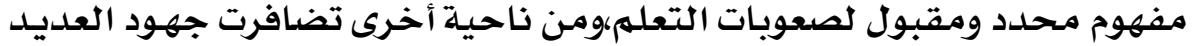

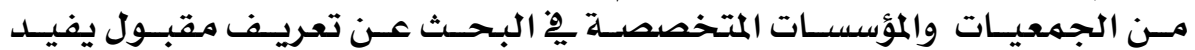

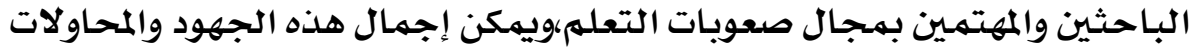

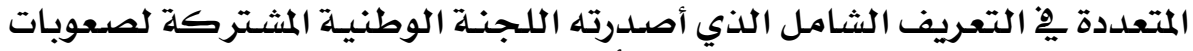

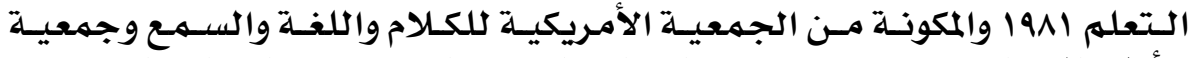

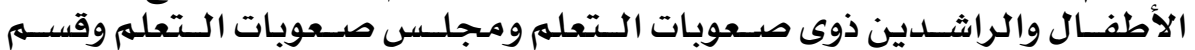

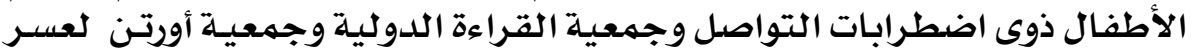




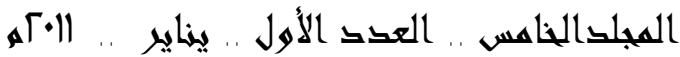

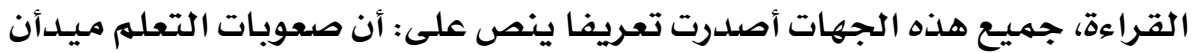

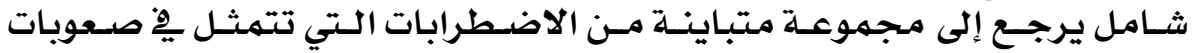

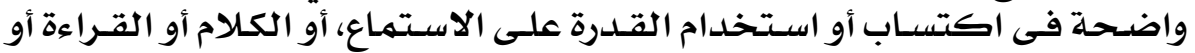

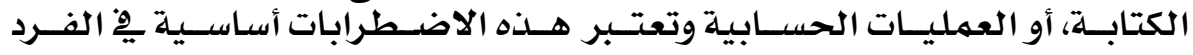

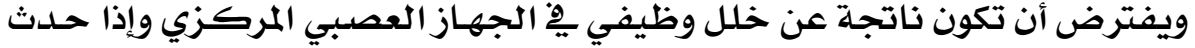

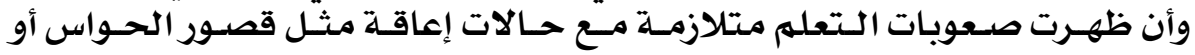

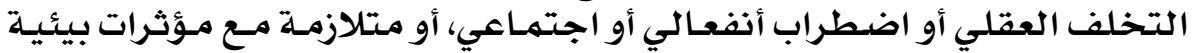

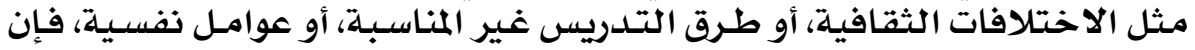

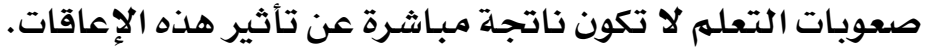

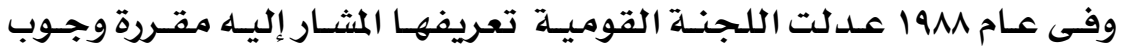

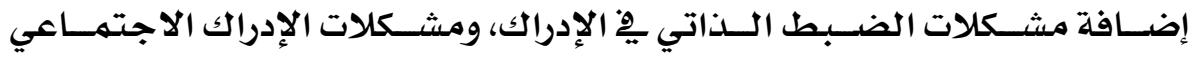

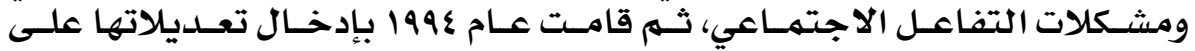

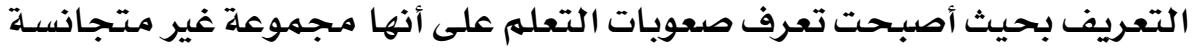

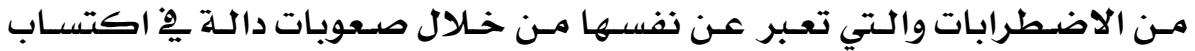

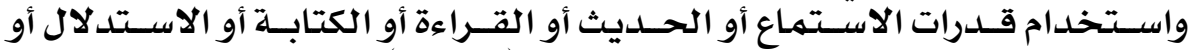

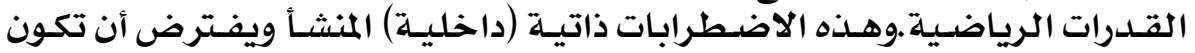

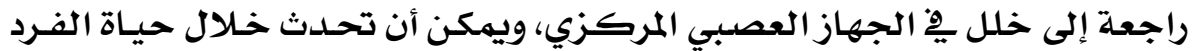

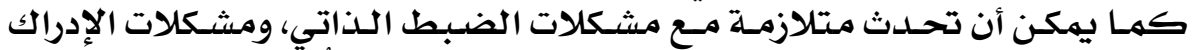

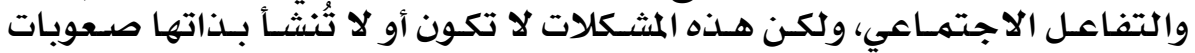

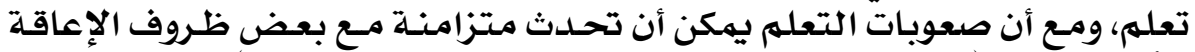

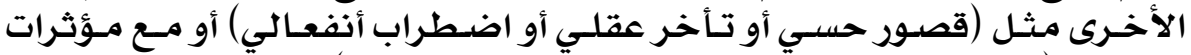

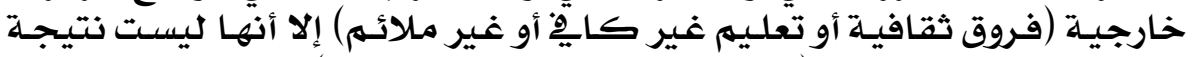

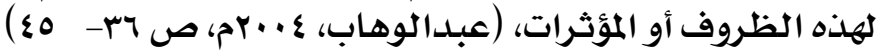

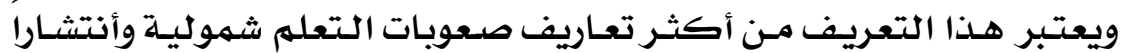

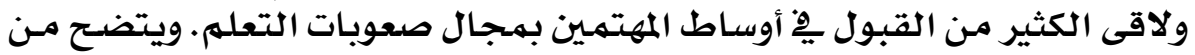

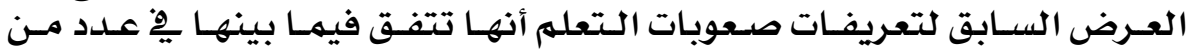
7 النقاط وهيدى : المتوقعهة.

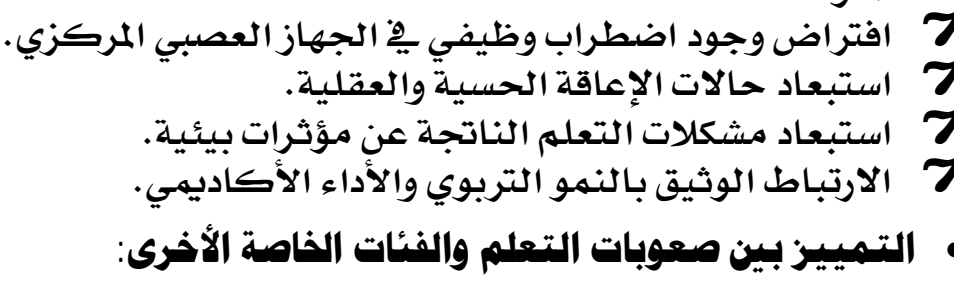

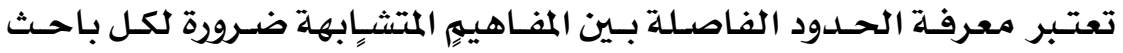

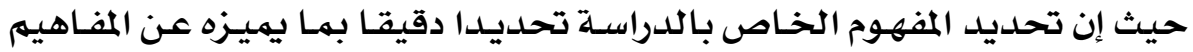




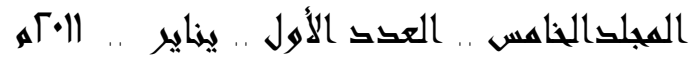

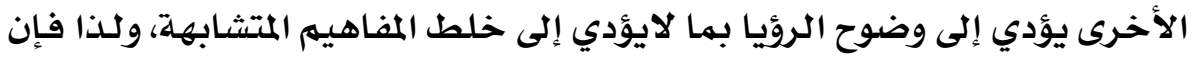

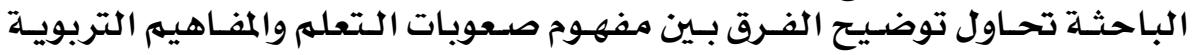

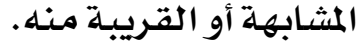

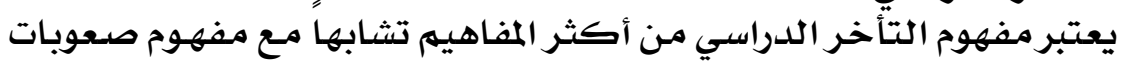

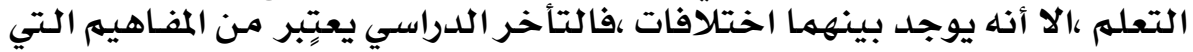

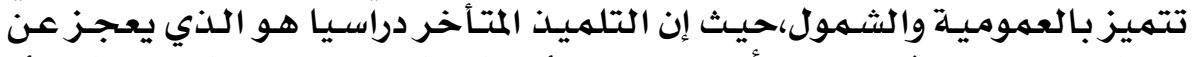

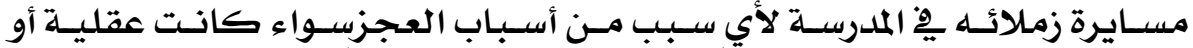

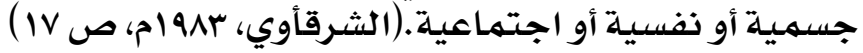

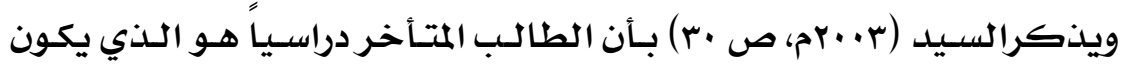

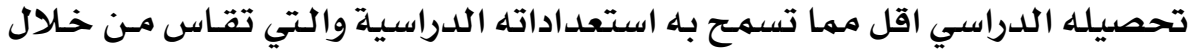

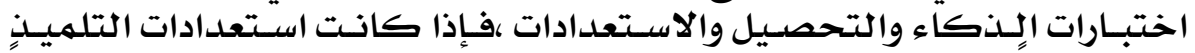

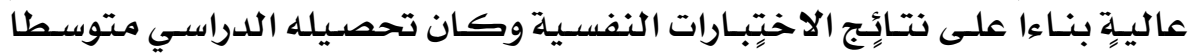

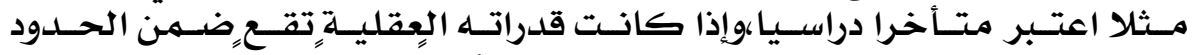

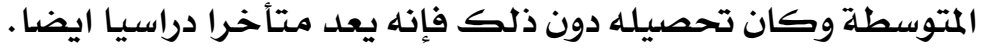

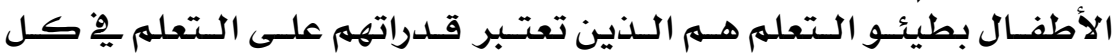

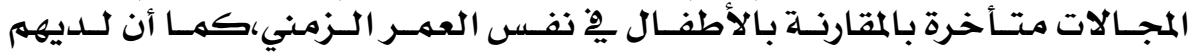

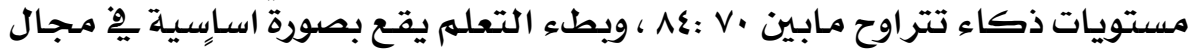

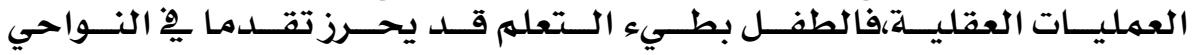

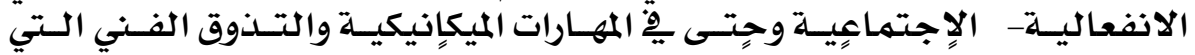

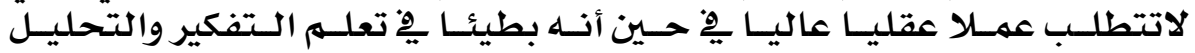

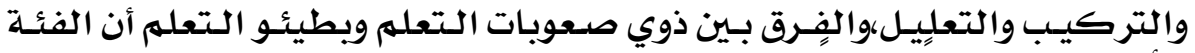

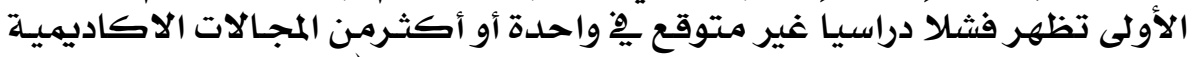

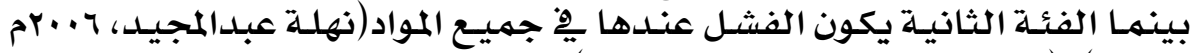

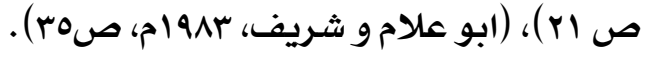

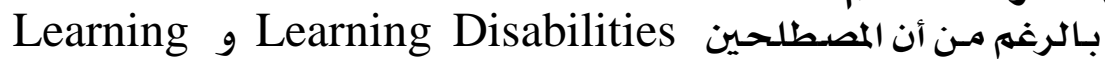

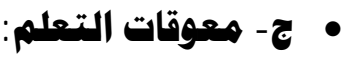

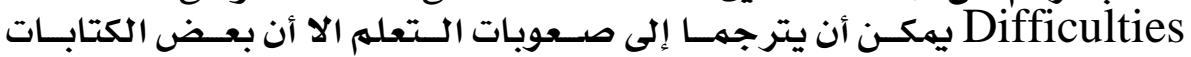

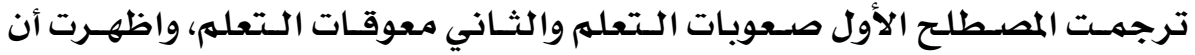

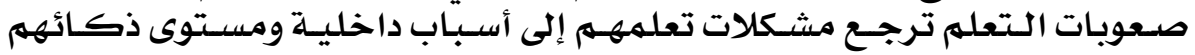

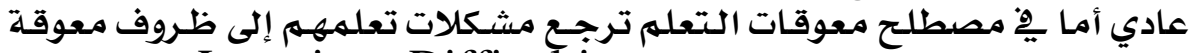

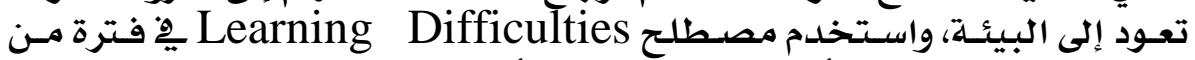

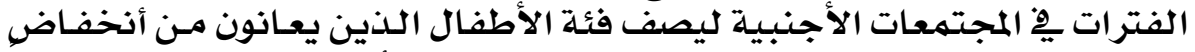

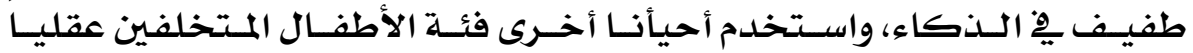




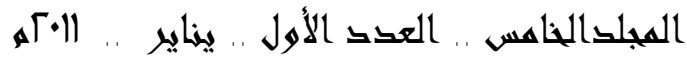

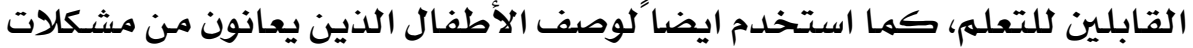

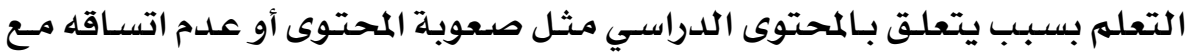

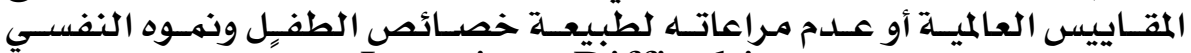

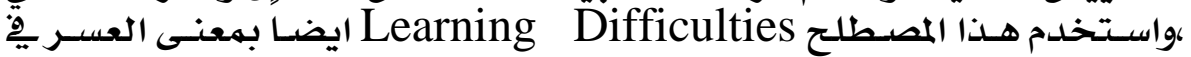

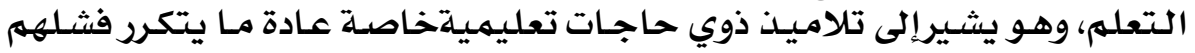

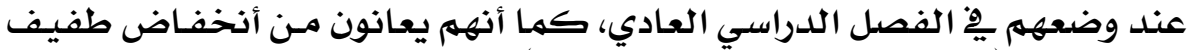

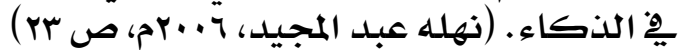

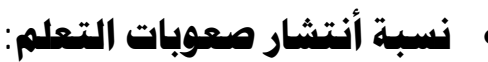

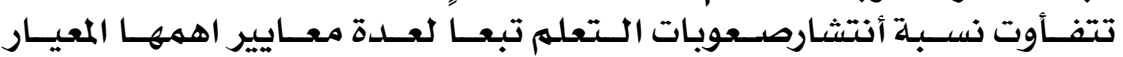

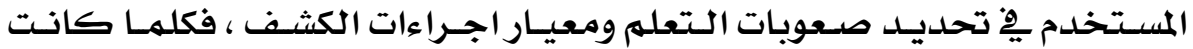

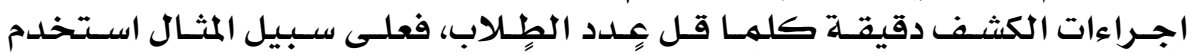

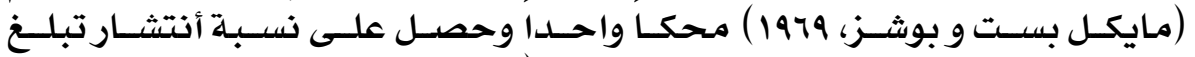

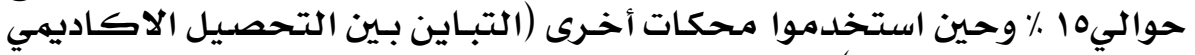

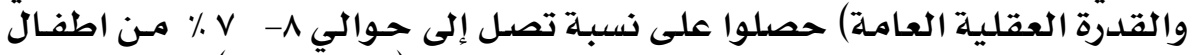

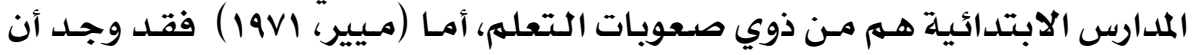

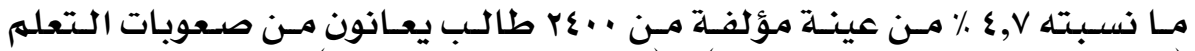

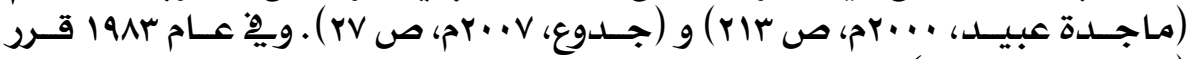

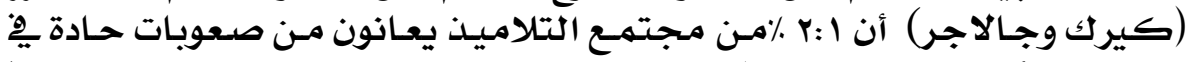

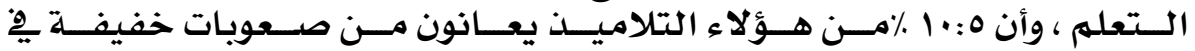

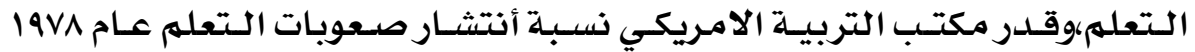

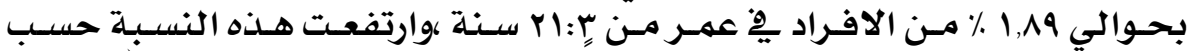

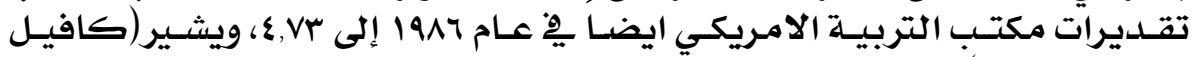

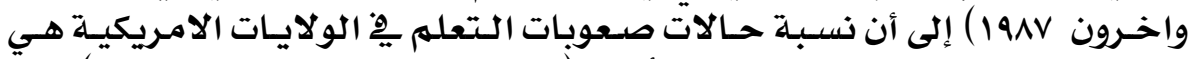

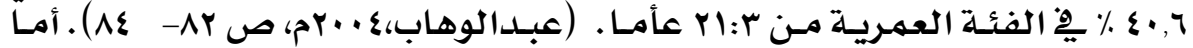

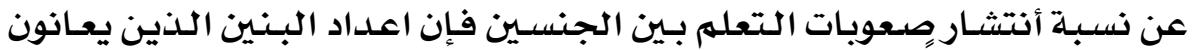

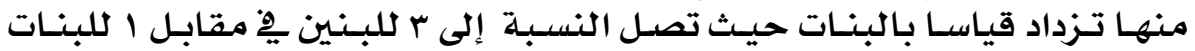

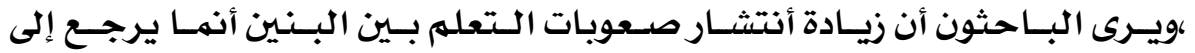

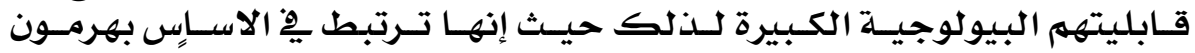

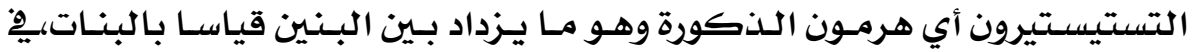

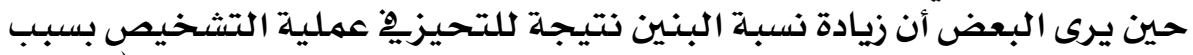

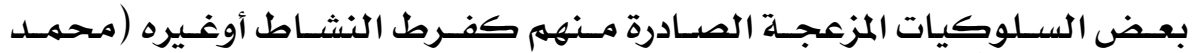

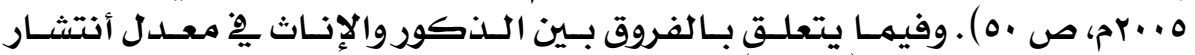

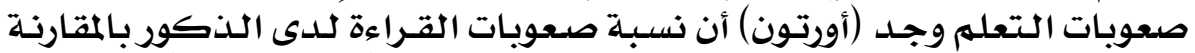

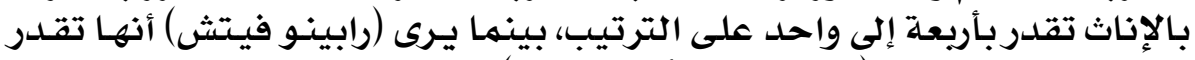

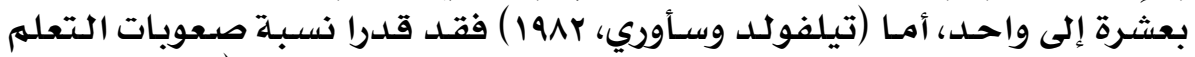

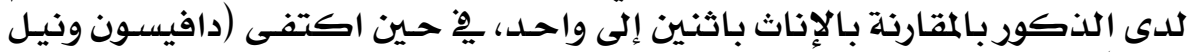

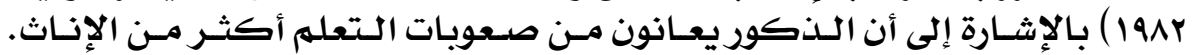

\section{Y४}


المجلى للخاهس .. العك الأول .. يناير .. الآمه

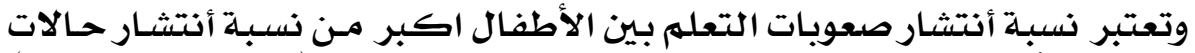

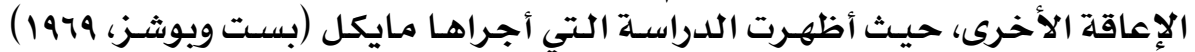

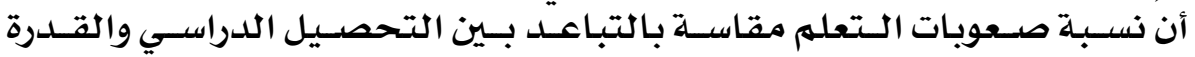

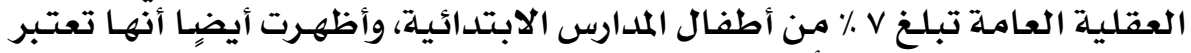

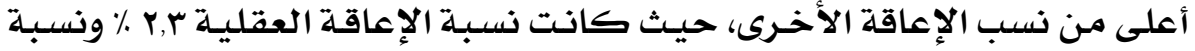

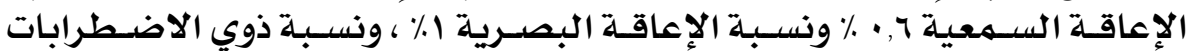

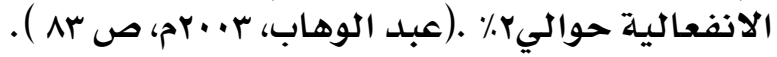

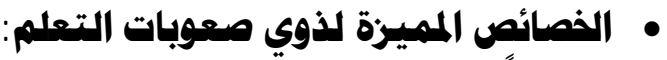

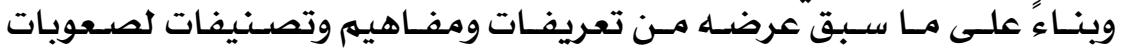

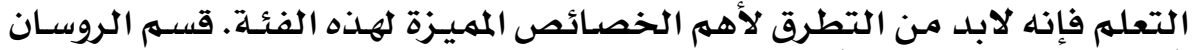

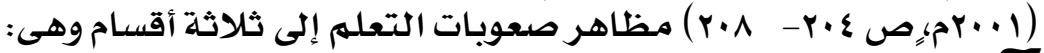

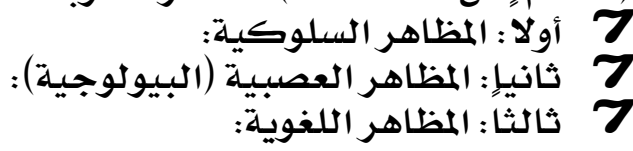

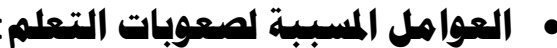

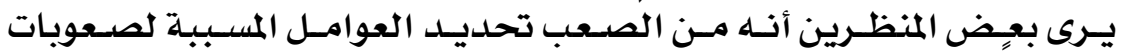

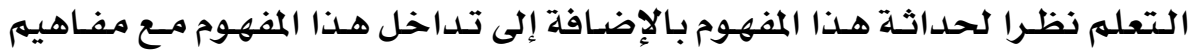

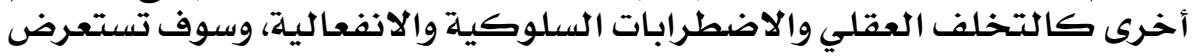

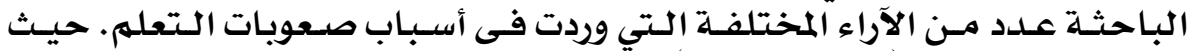

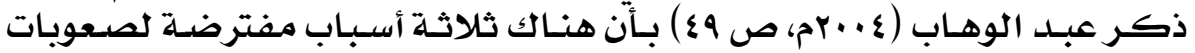

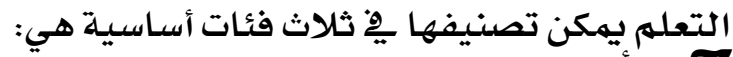

$$
\begin{aligned}
& 7 \\
& 7 \\
& 7
\end{aligned}
$$

7

$$
7
$$

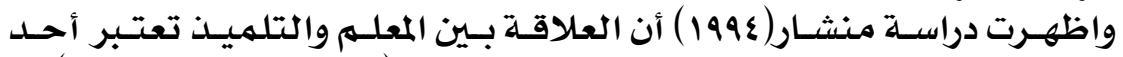

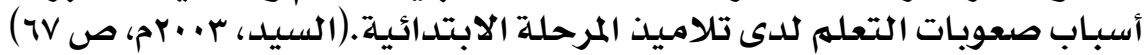

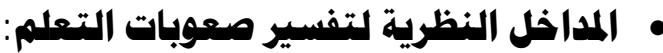

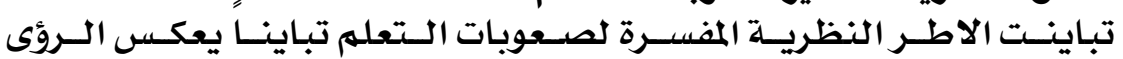

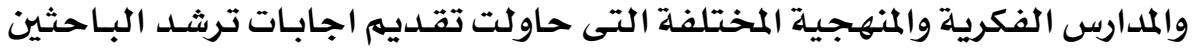

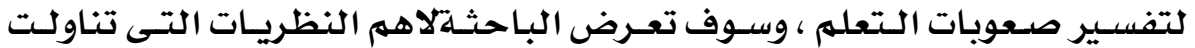

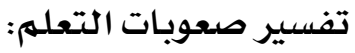

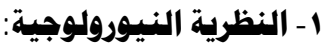

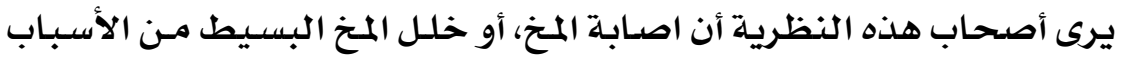

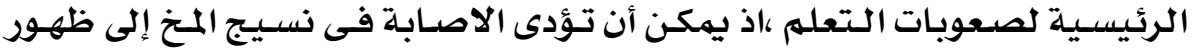

\section{Y77}




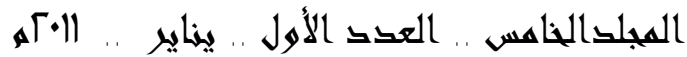

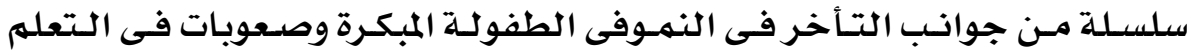

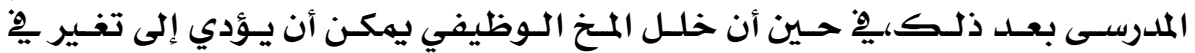

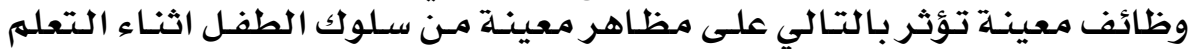

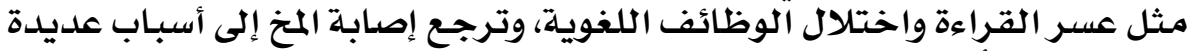

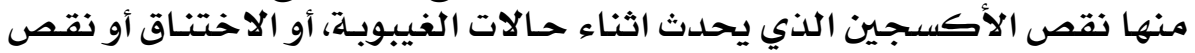

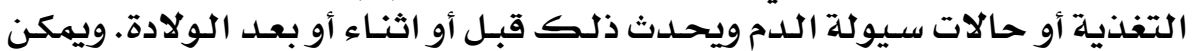

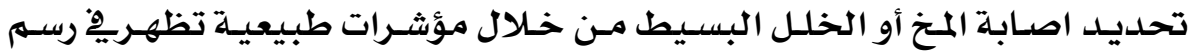

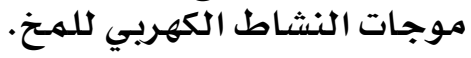

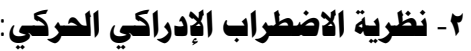

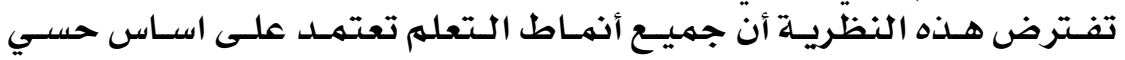

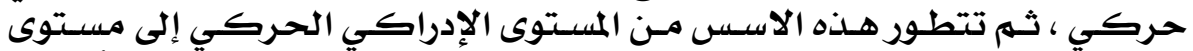

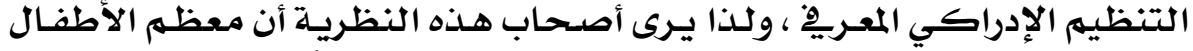

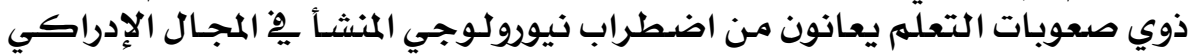

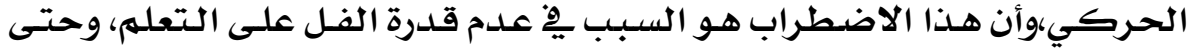

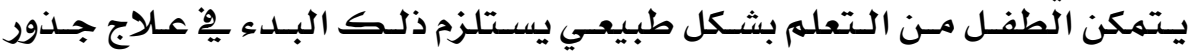

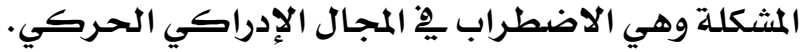

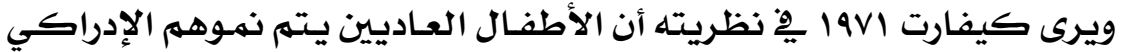

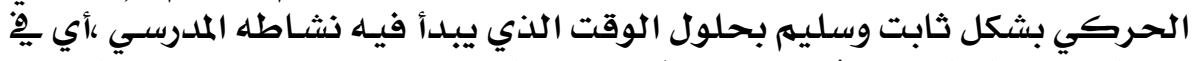

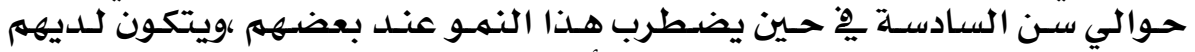

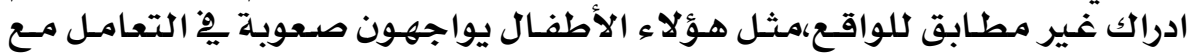

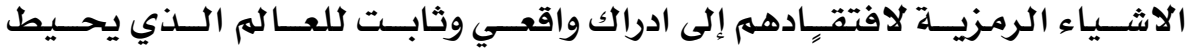

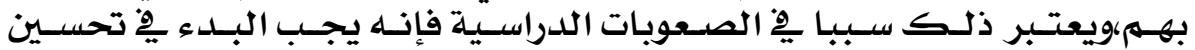

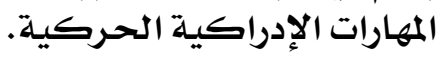

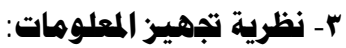

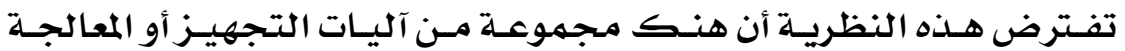

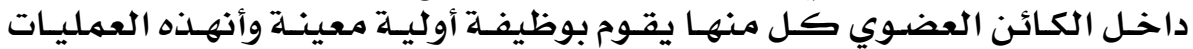

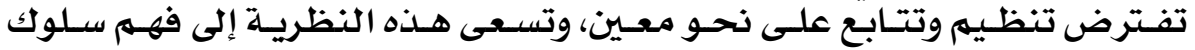

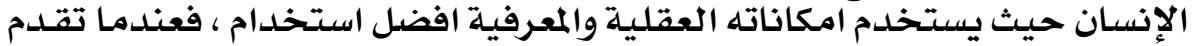

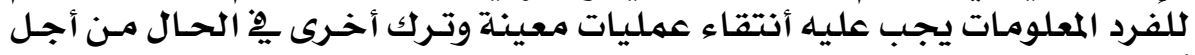
أنجاز المهمة المستهـدفة ليجة.

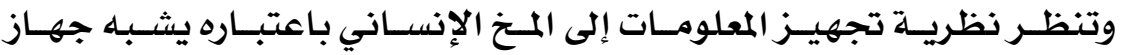

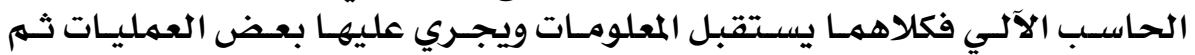

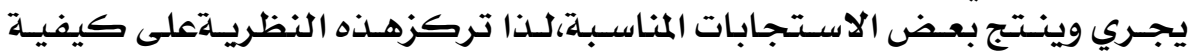

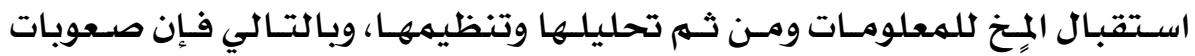

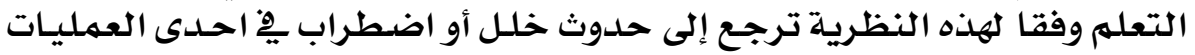

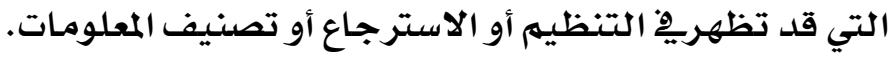


المجلى الخاهس .. العقد الأول .. يناير .. المه

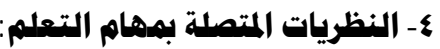

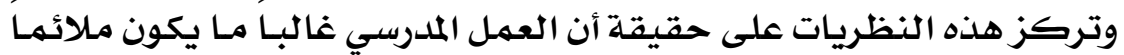

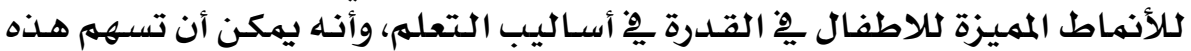

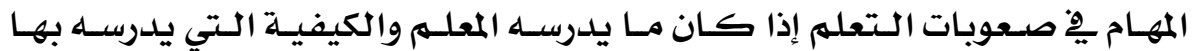

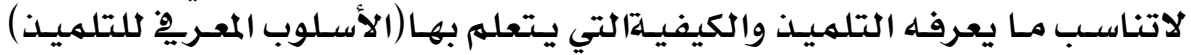
وتتضمن هذه النظريات اتجاهين لتفسير صعوبـات التعلهم هما:

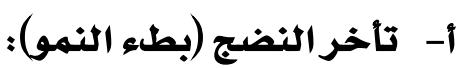

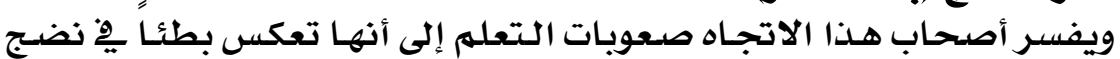

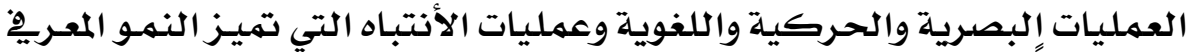

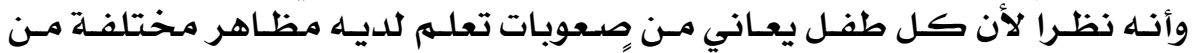

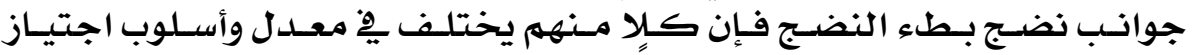

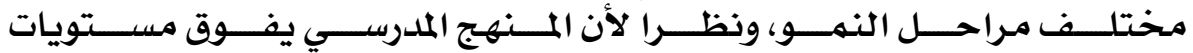

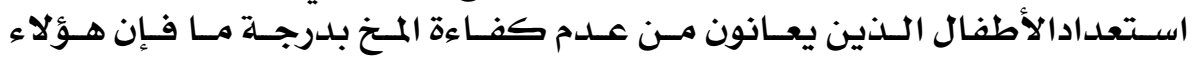

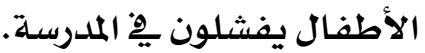

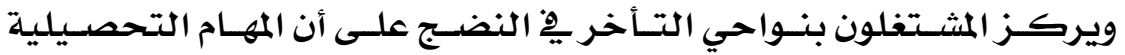

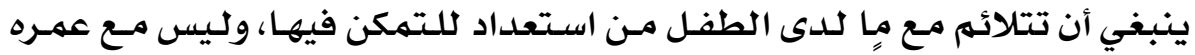

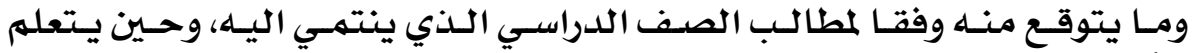

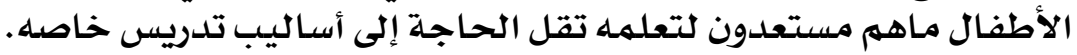

ب- الأساليب المعرفية:

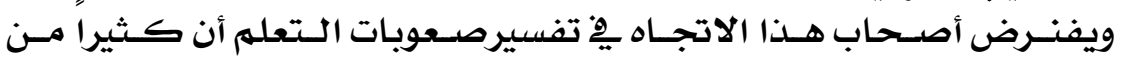

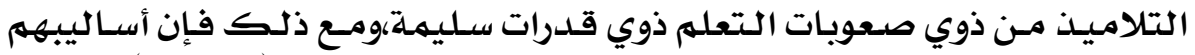

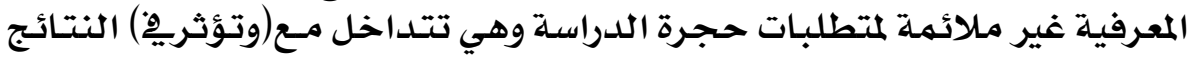

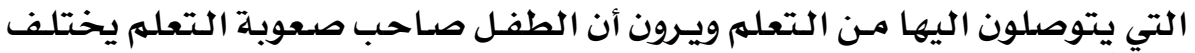

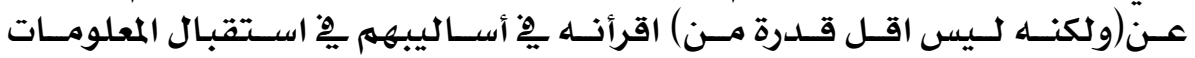

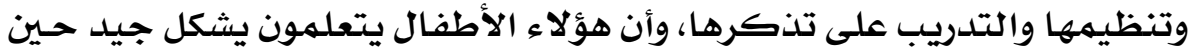

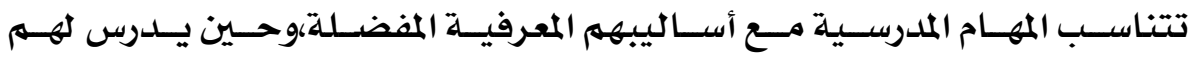

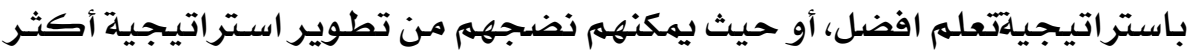

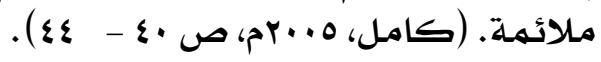

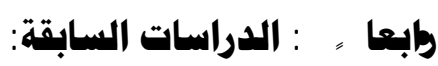

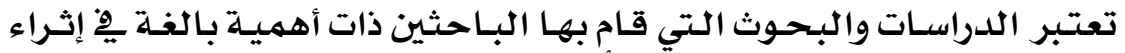

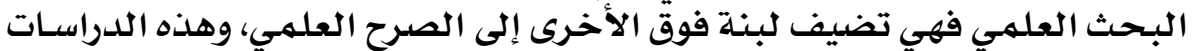

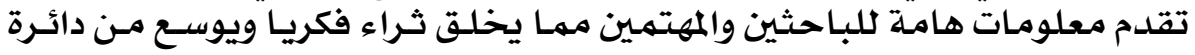

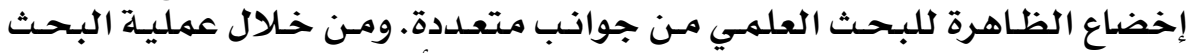

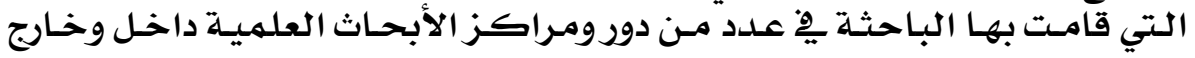

\section{Yฯ}




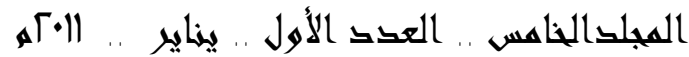

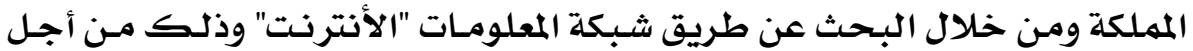

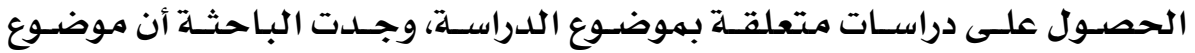

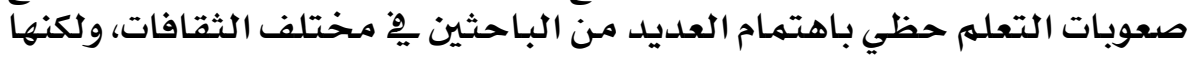

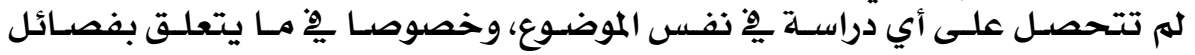

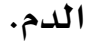

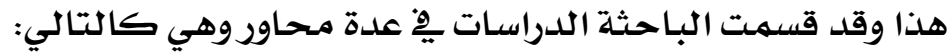

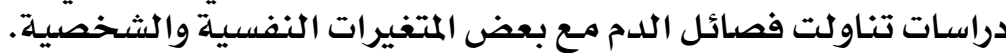

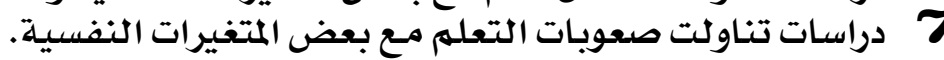

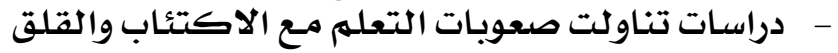

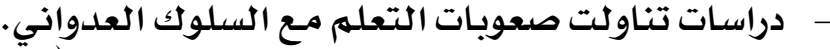

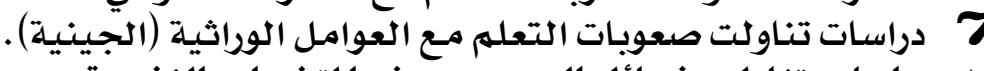

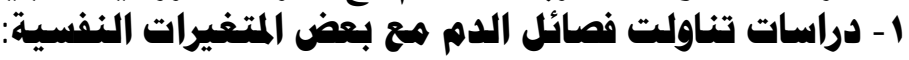

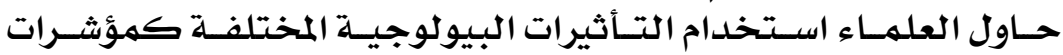

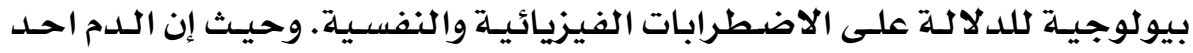

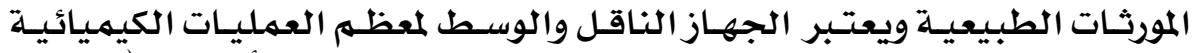

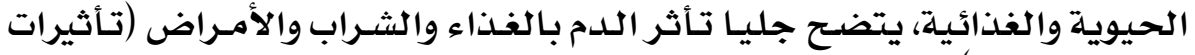

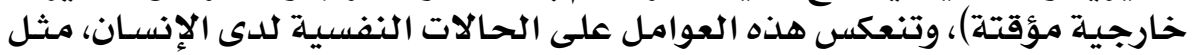

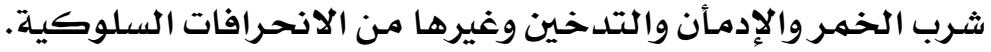

وفصائل الدم (A, B, AB and O) تعتبر احس المورثات الأسـاسية التحرئي

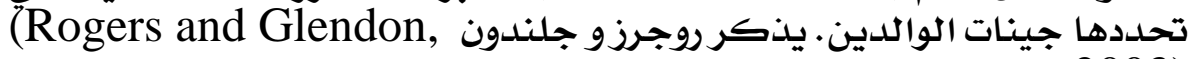

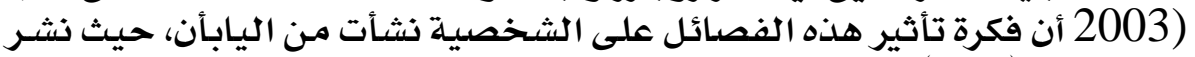

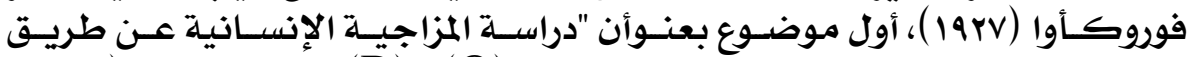

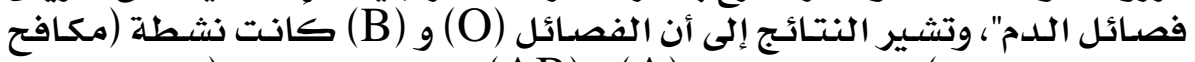

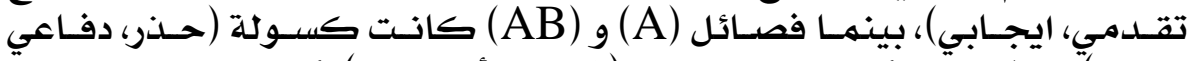

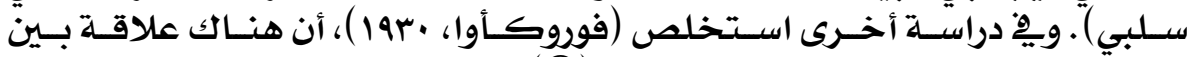

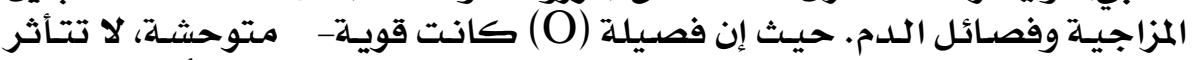

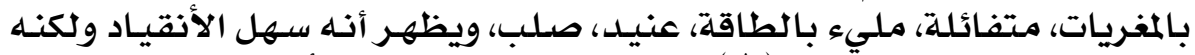

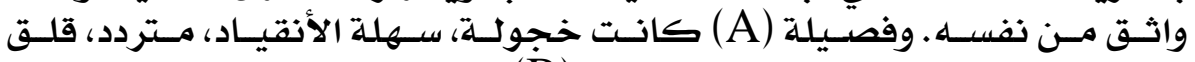

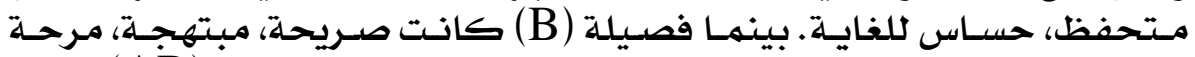

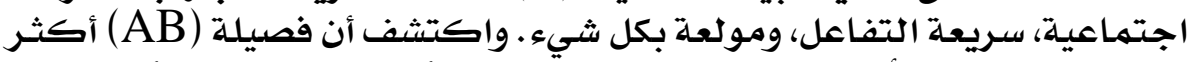

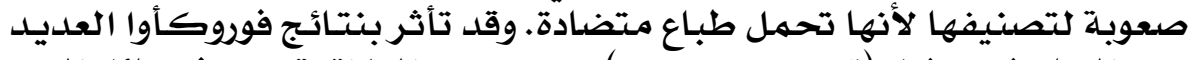

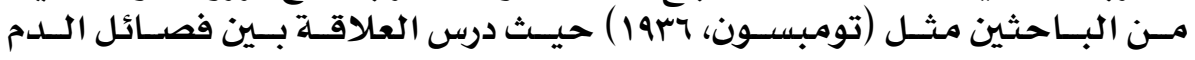

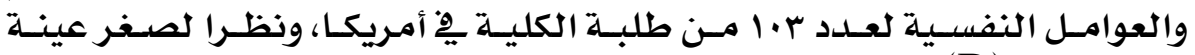

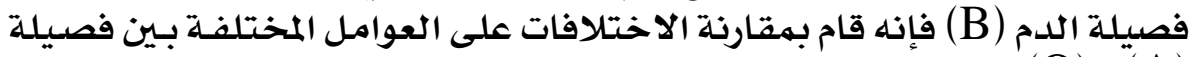

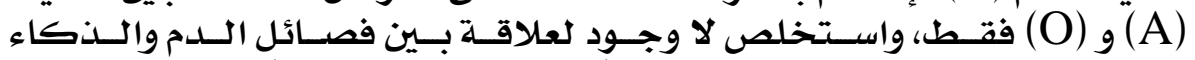

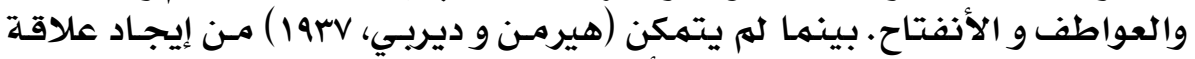

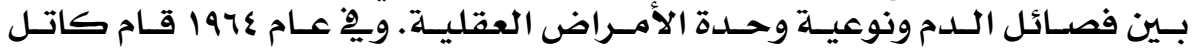

\section{Y 99}




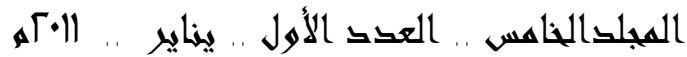

وبوترلاين و هوندليبي (Cattell, Boutourline, and Hundleby, 1964)

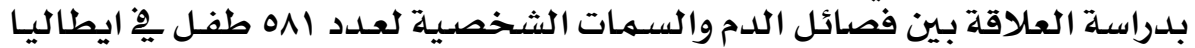

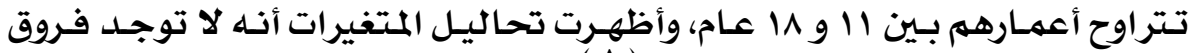

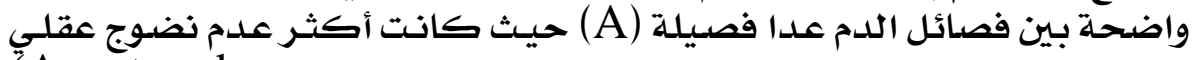

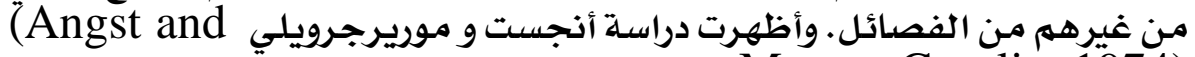

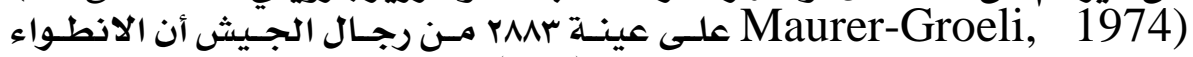

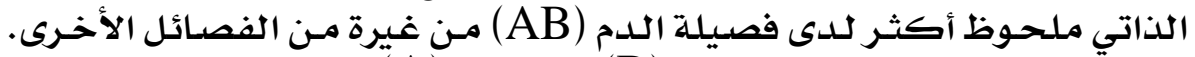

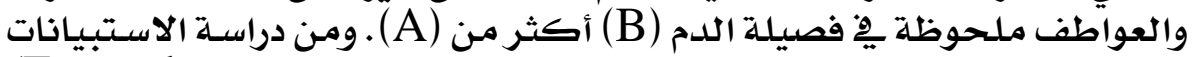

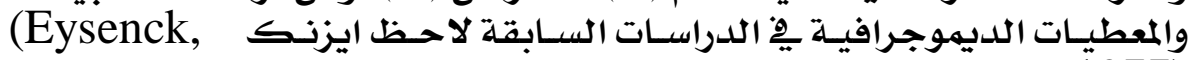

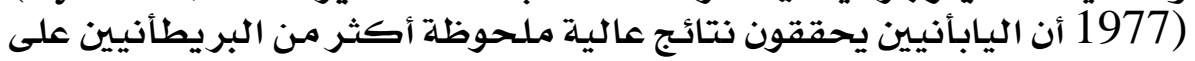

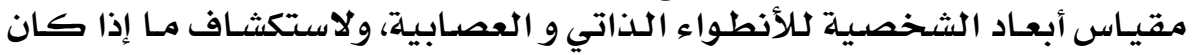

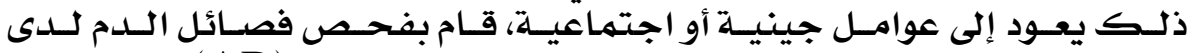

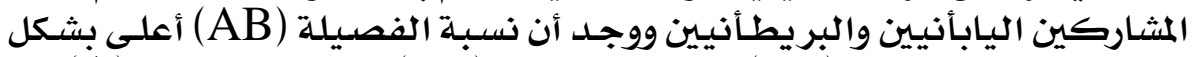

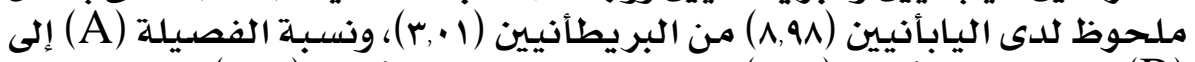

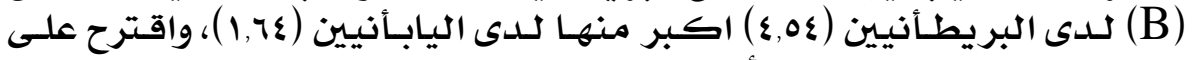

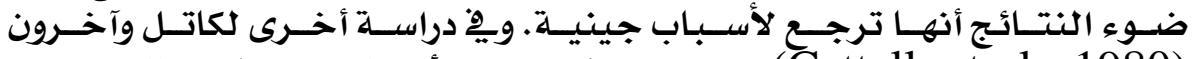
(Cattell, et al., 1980)

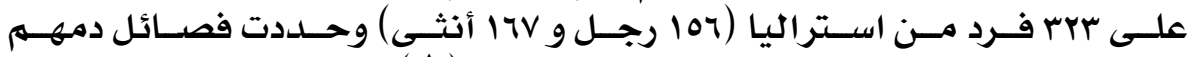

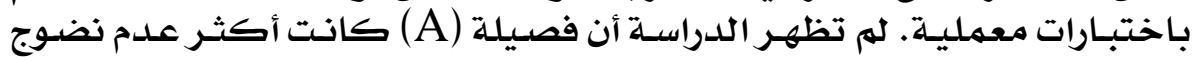

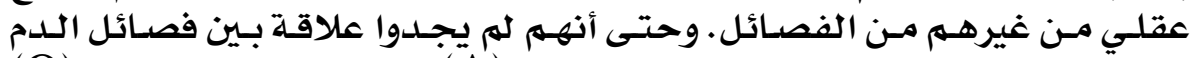

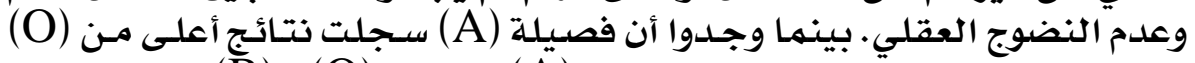

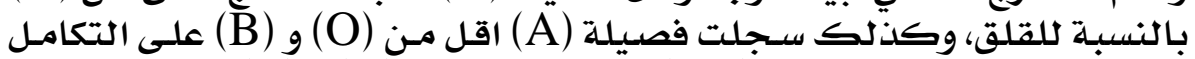

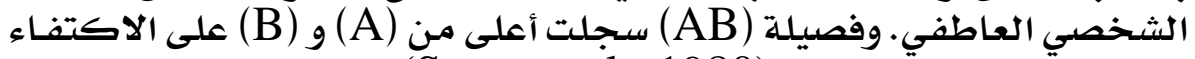

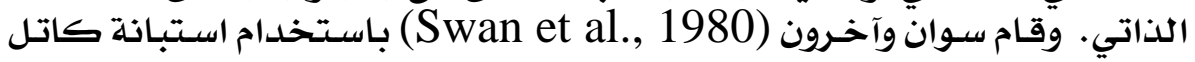

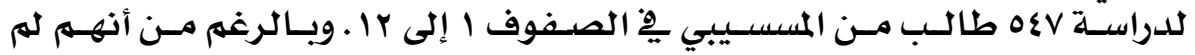

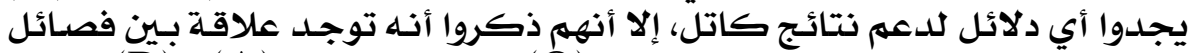

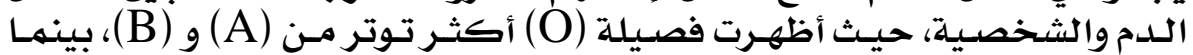

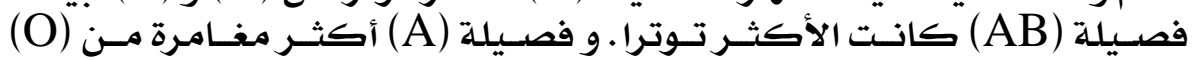

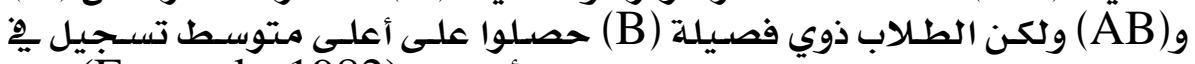

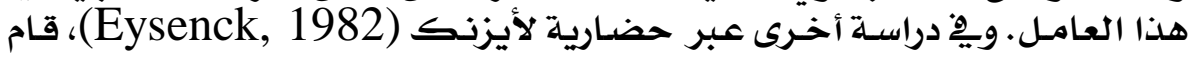

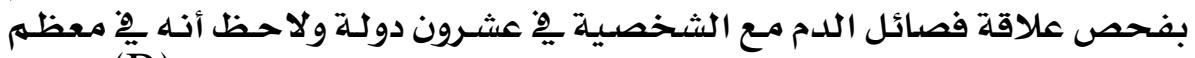

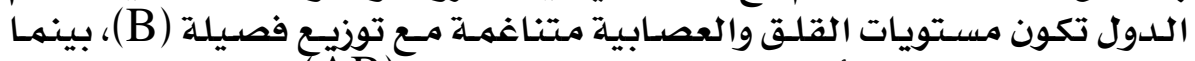

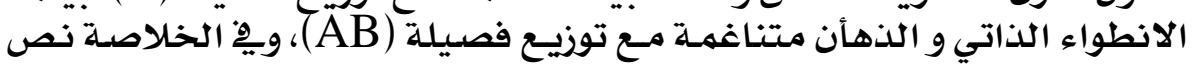

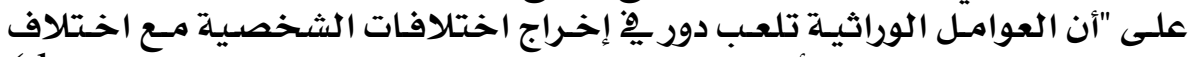

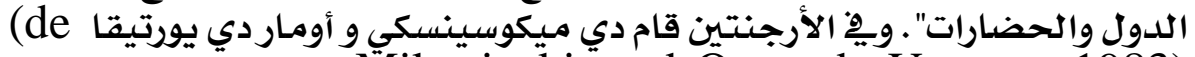
(Mikusinski, and Ömar de Urteaga, 1983)

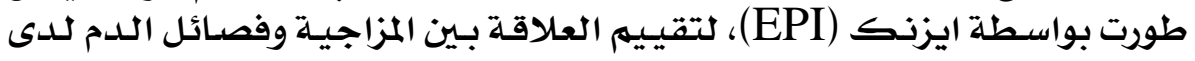

\section{YV。}




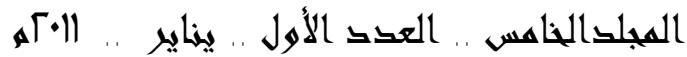

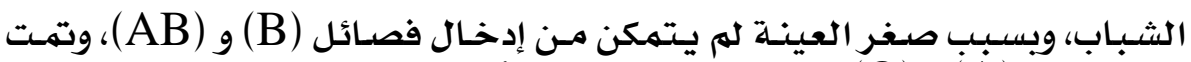

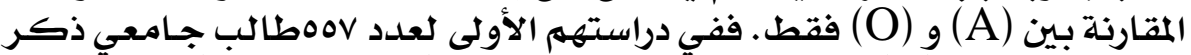

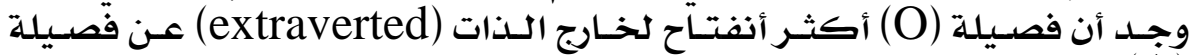

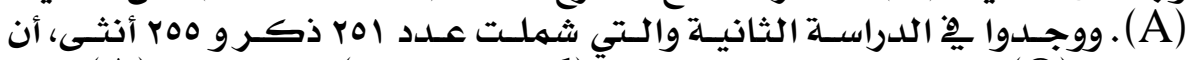

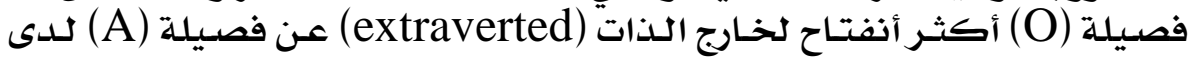

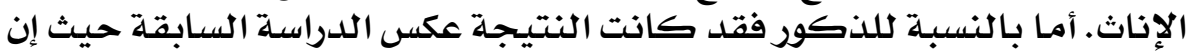

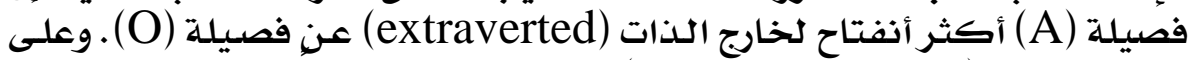

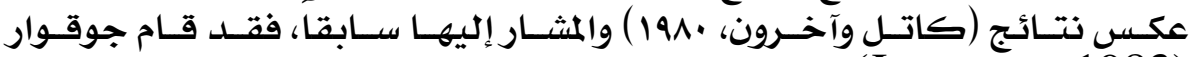

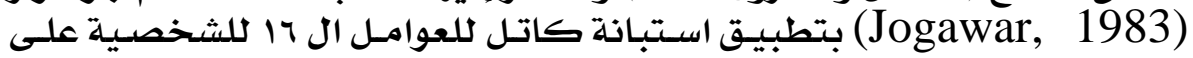

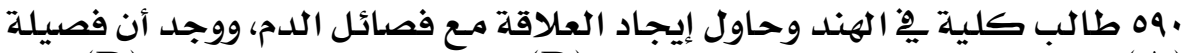

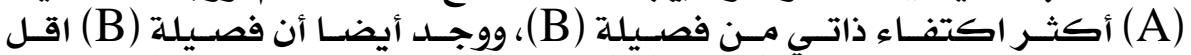

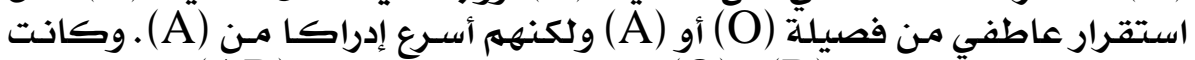

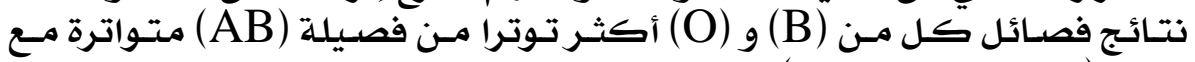

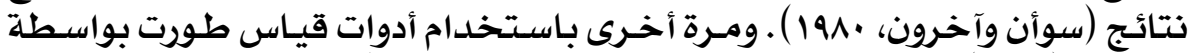

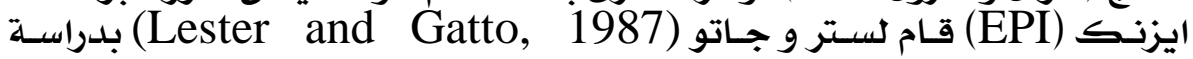

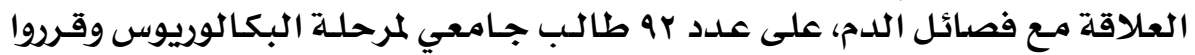

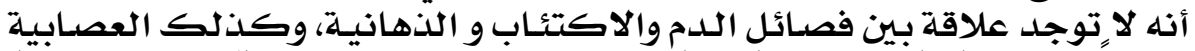

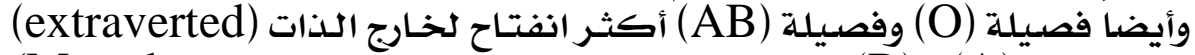

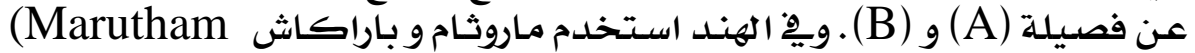
(And Prakash, 1990)

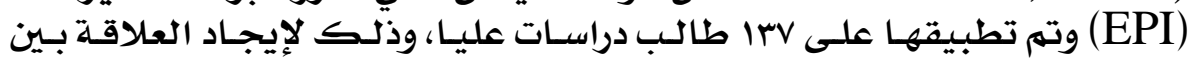

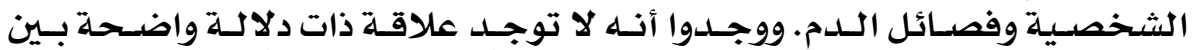

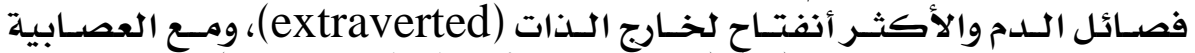

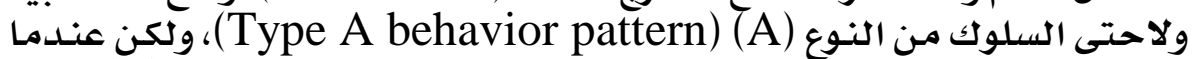

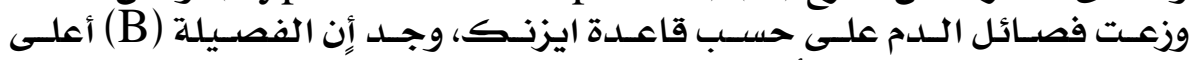

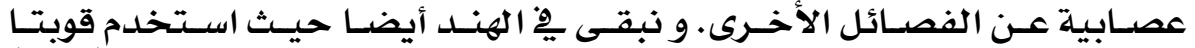

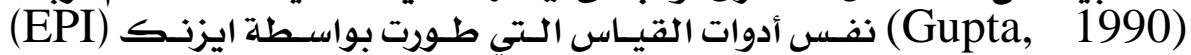

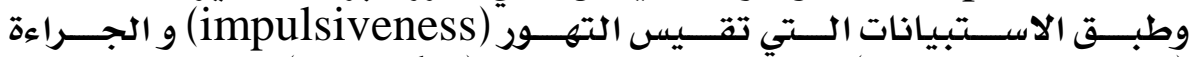

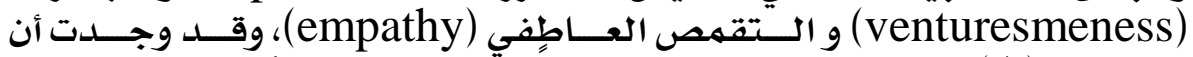

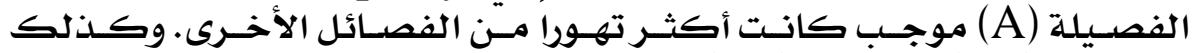

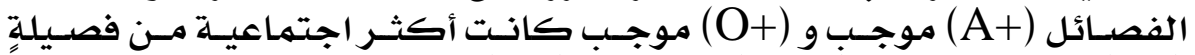

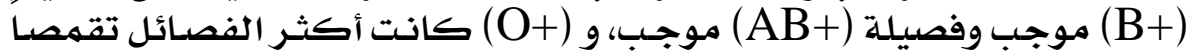

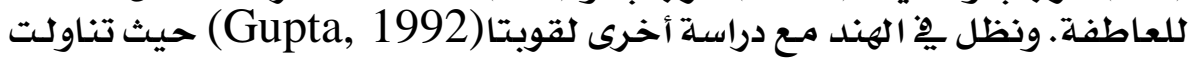

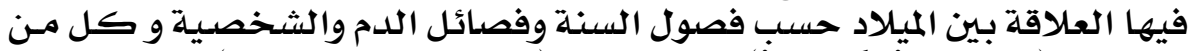

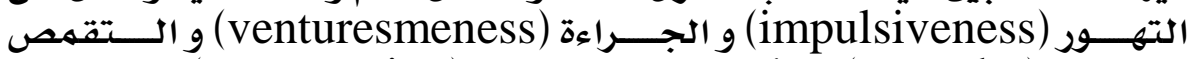

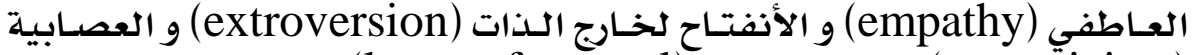

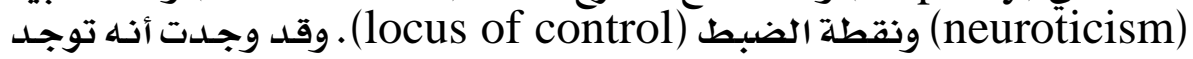


المجلى للخاهس .. العك الأول .. يناير .. الآم

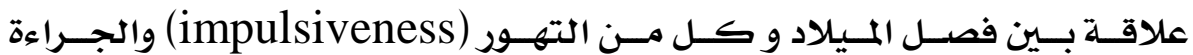
(venturesmeness)

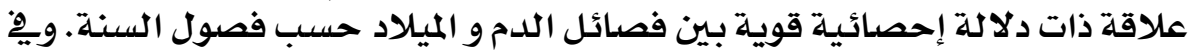

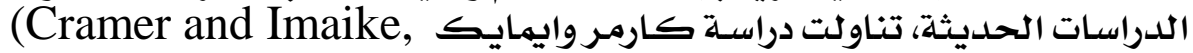

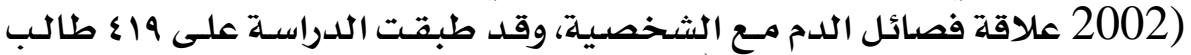

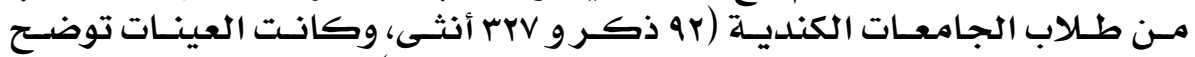

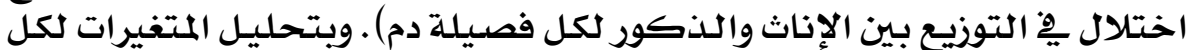

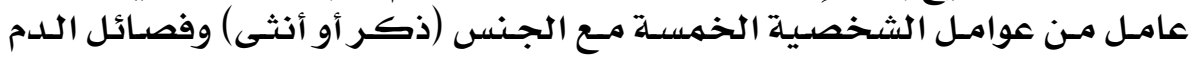

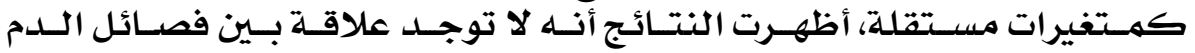

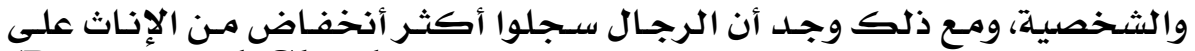

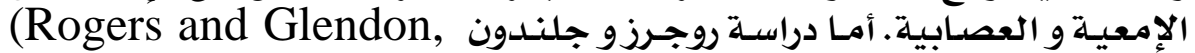

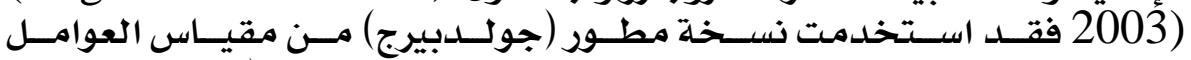

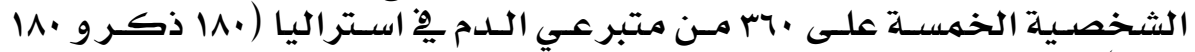

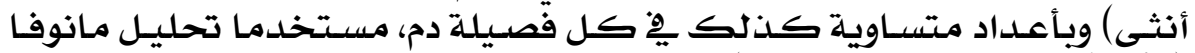

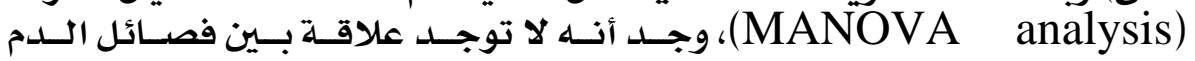
والشخصية.

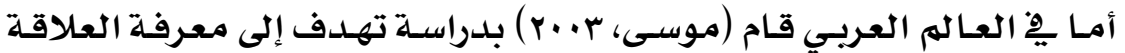

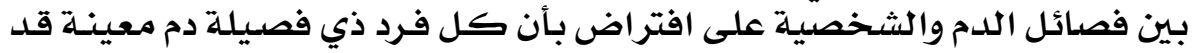

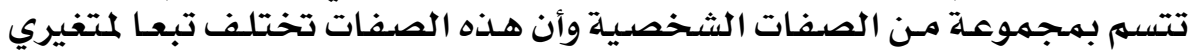

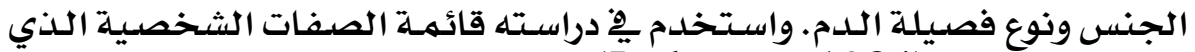

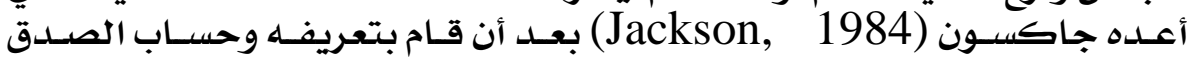

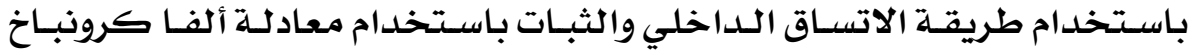

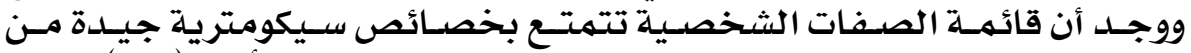

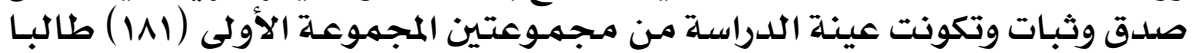

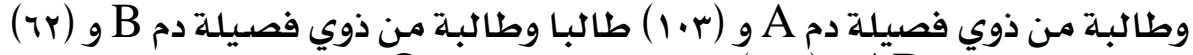

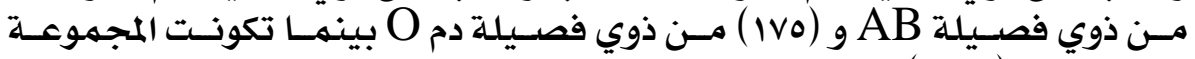

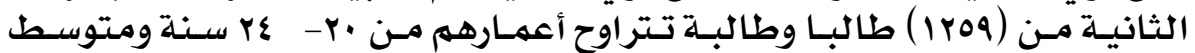

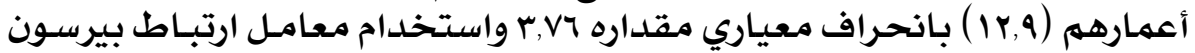

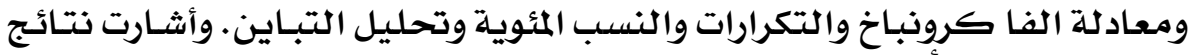

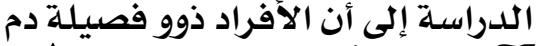

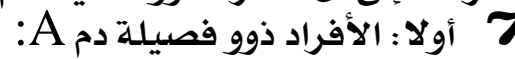

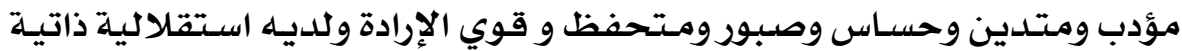

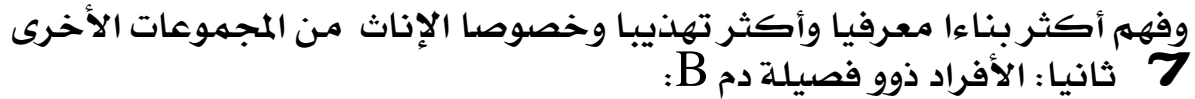

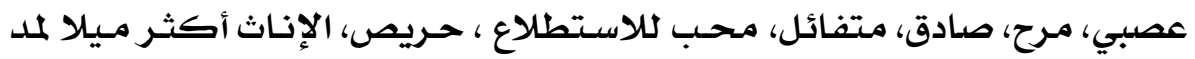

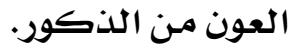

\section{YVY}

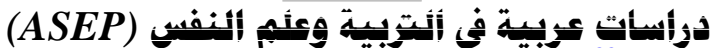




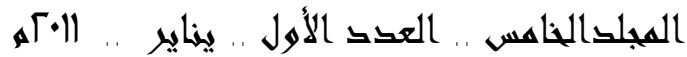

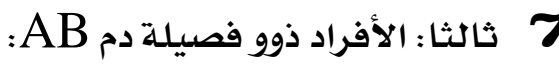

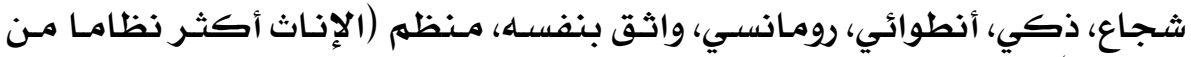

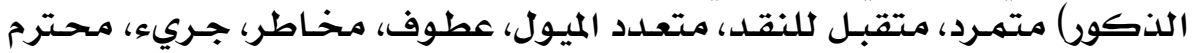

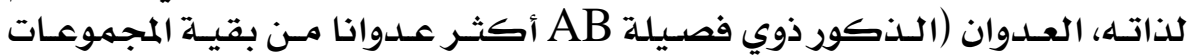

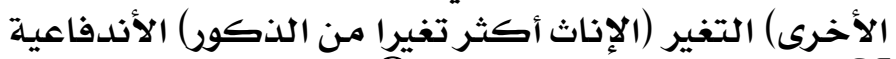

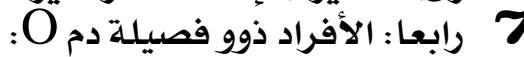

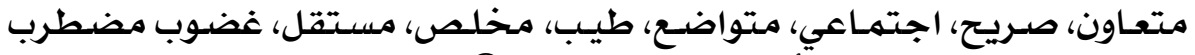

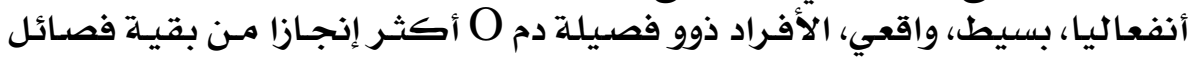

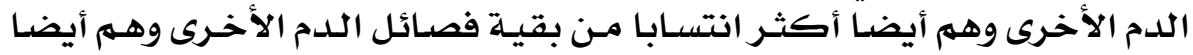

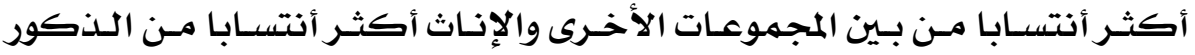
والذكور أكثر أنجازا من الإناث.

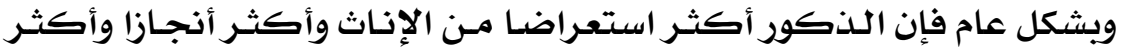

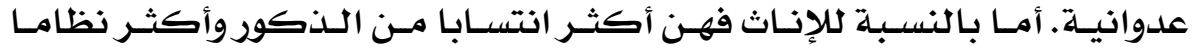

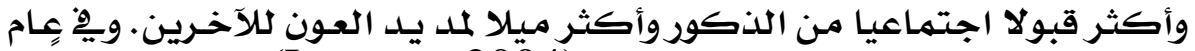

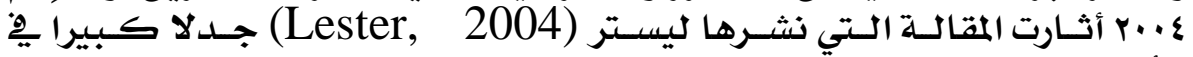

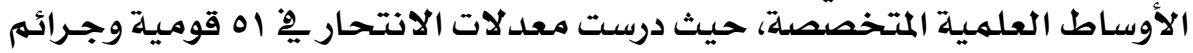

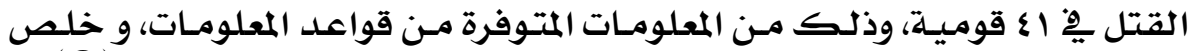

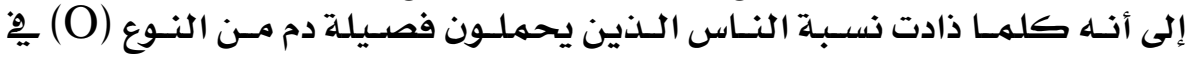

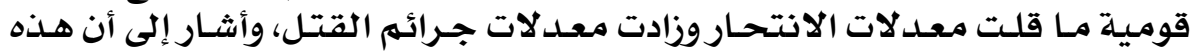

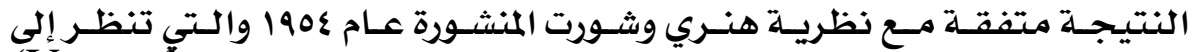

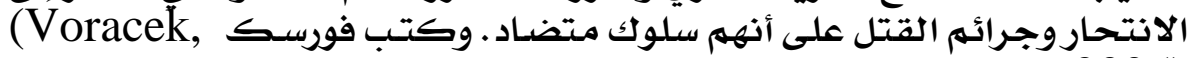

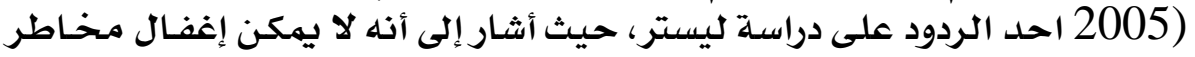

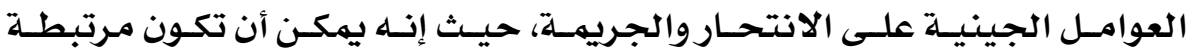

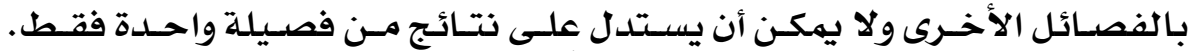

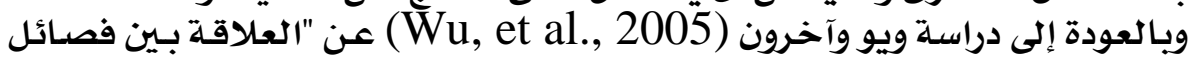

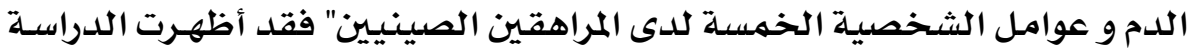

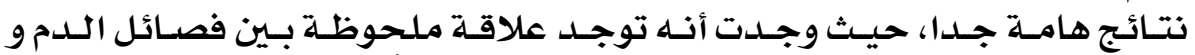

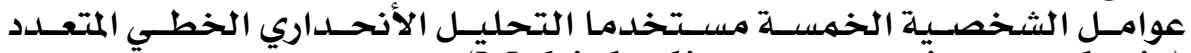
(Multiple liner regression analysis)

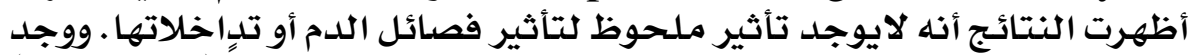

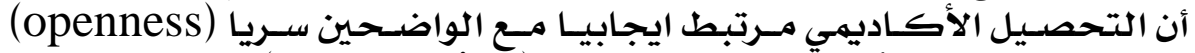

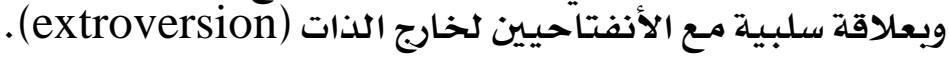

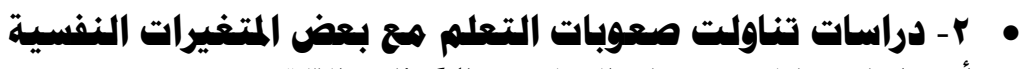

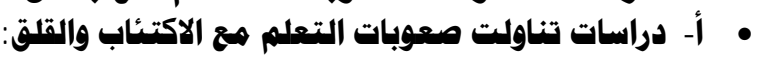

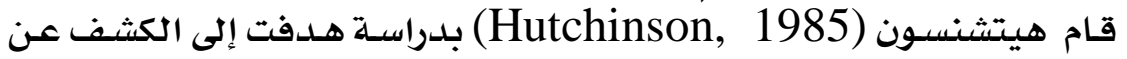

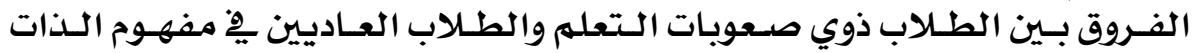

\section{YVY}




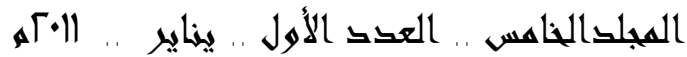

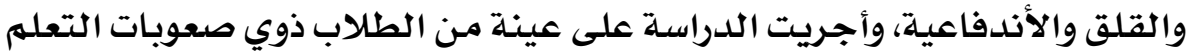

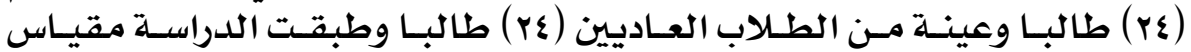

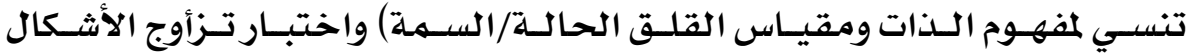

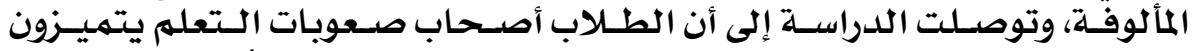

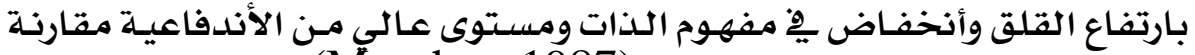

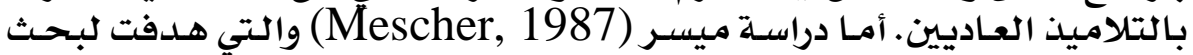

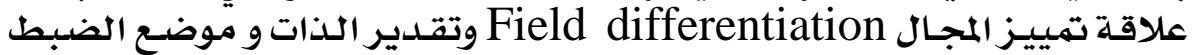

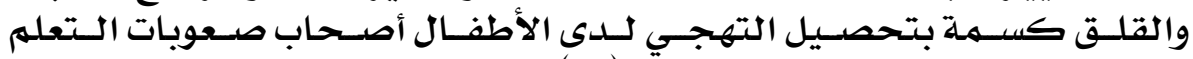

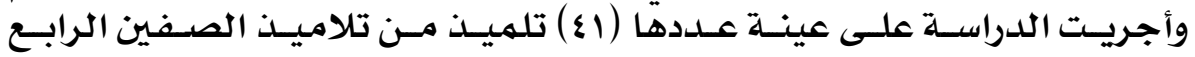

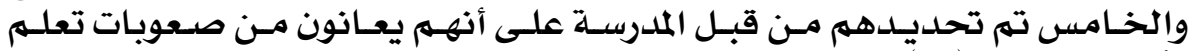

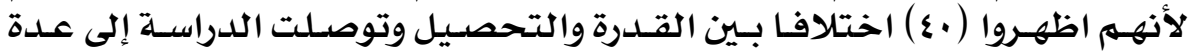

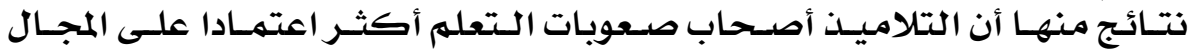

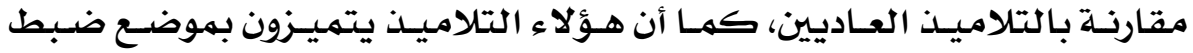

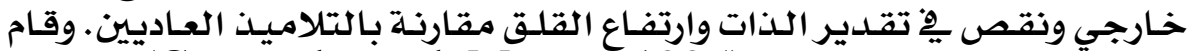

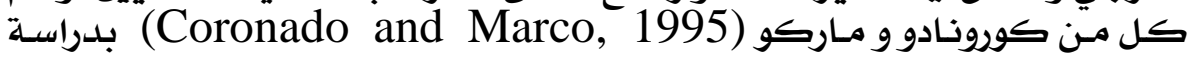

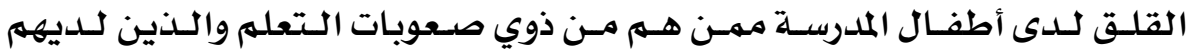

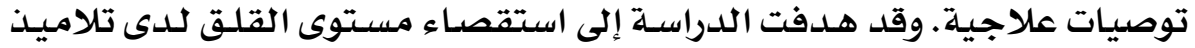

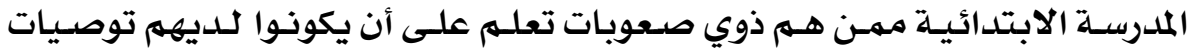

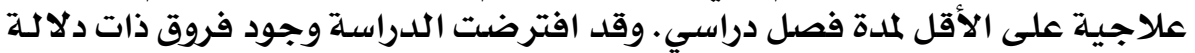

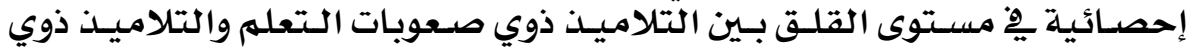

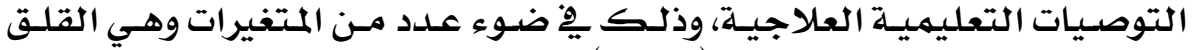

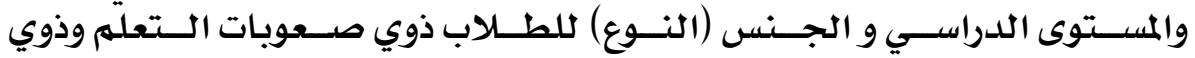

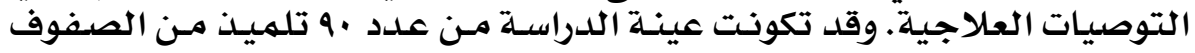

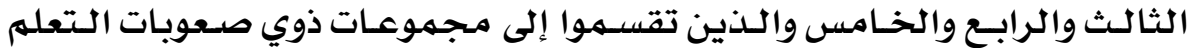

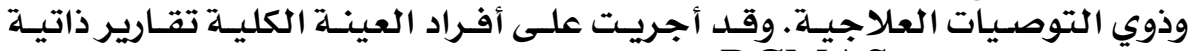

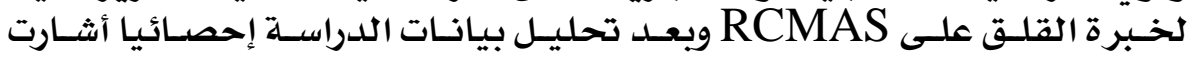

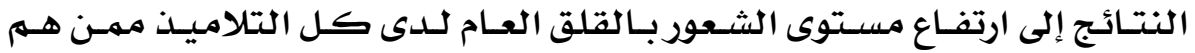

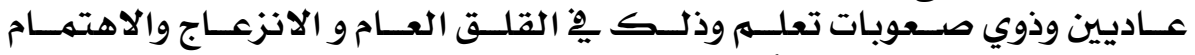

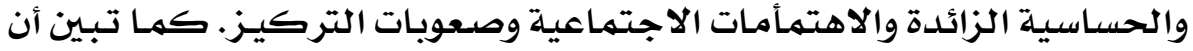

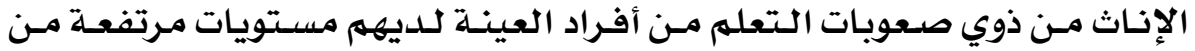

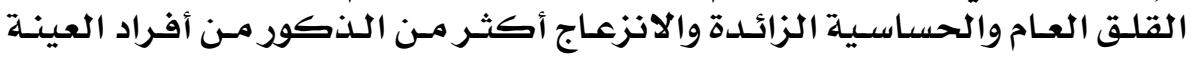

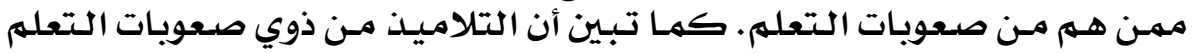

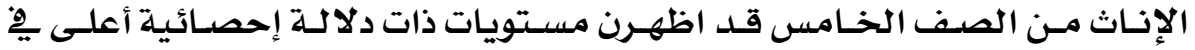

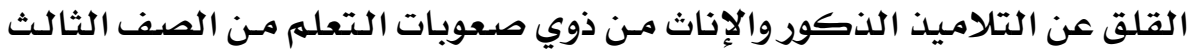
والرابع · عن عن

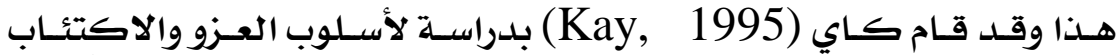

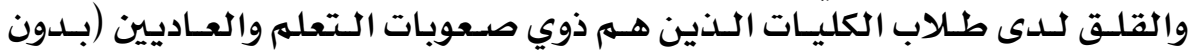

\section{YV $\varepsilon$}




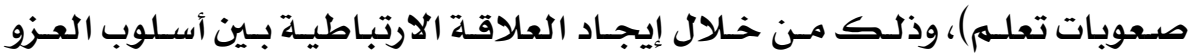

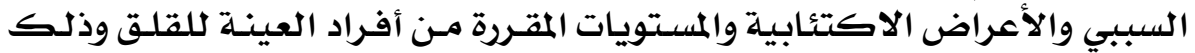

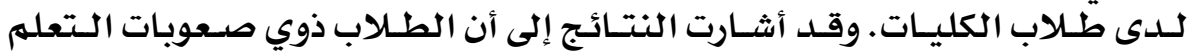

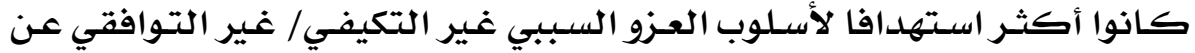

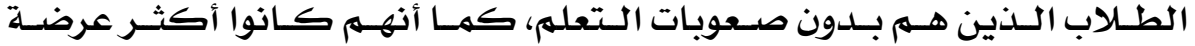

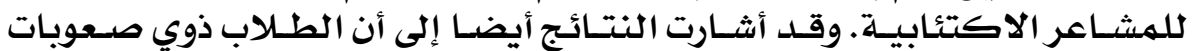

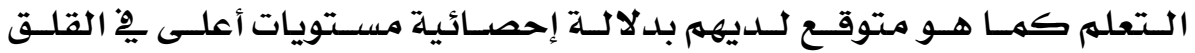

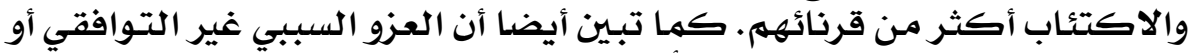

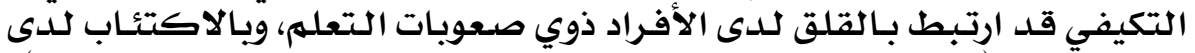

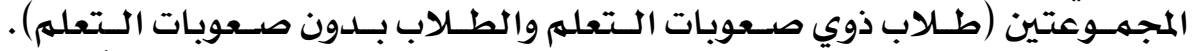

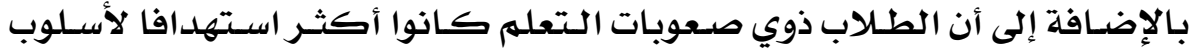

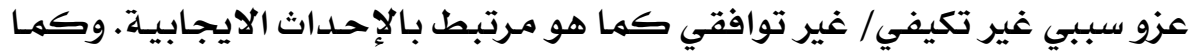

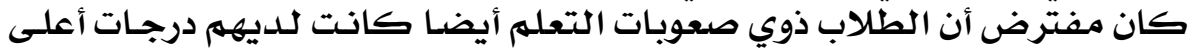

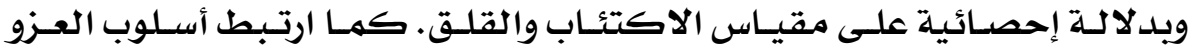

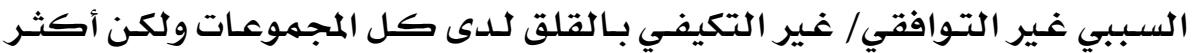

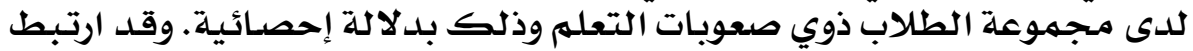

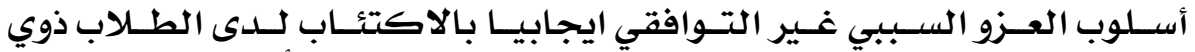

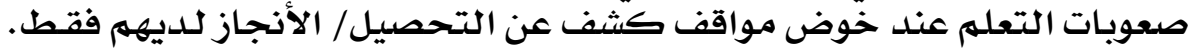

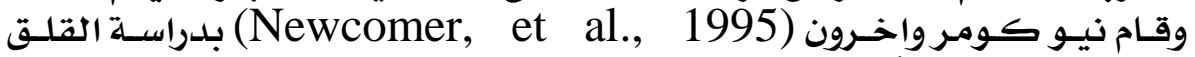

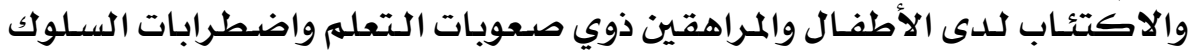

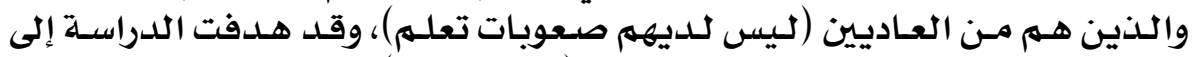

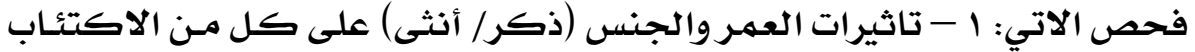

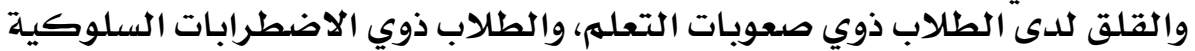

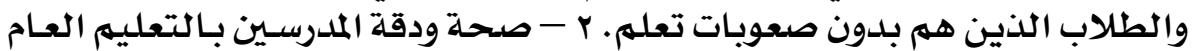

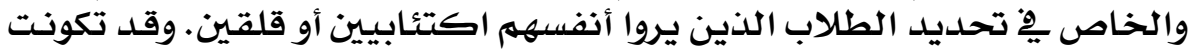

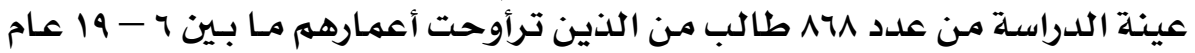

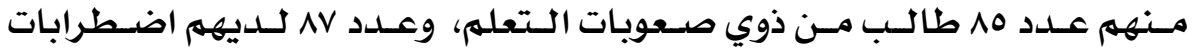

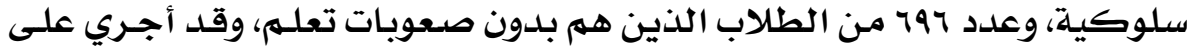

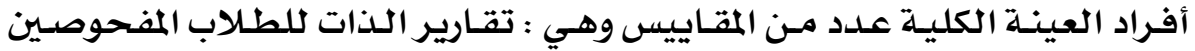

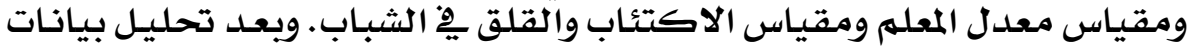

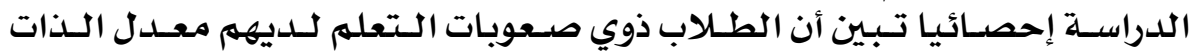

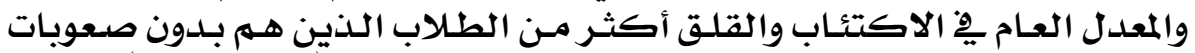

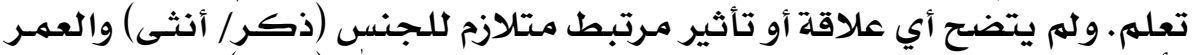

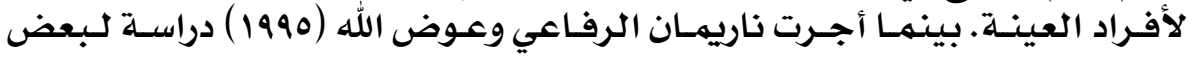

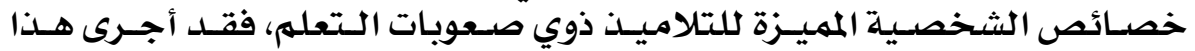

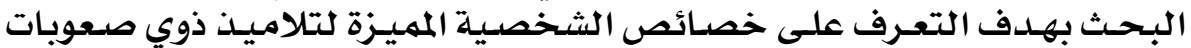

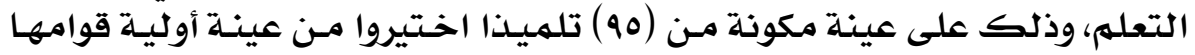

\section{YV०}




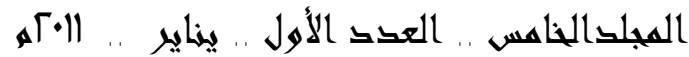

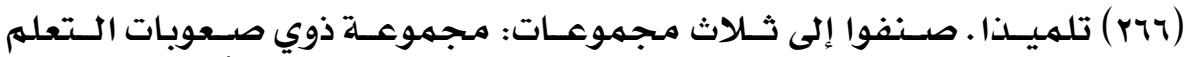

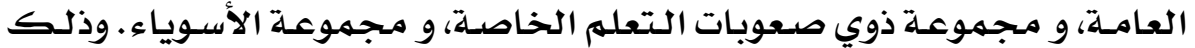

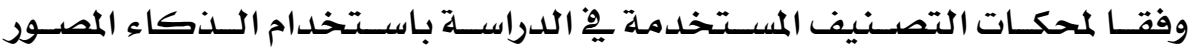

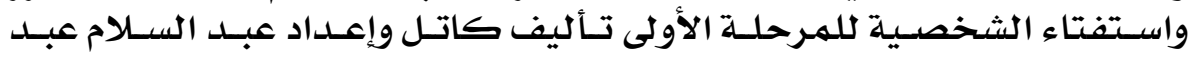

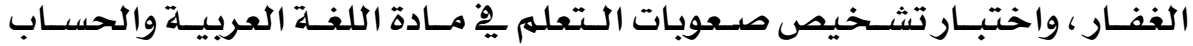

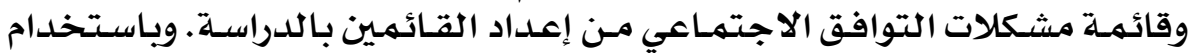

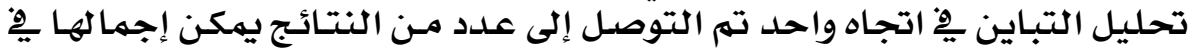

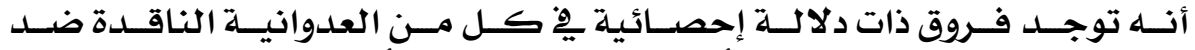

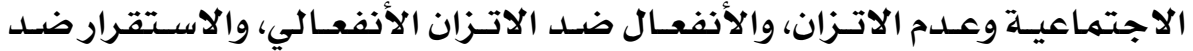

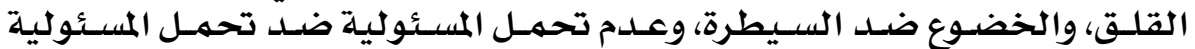

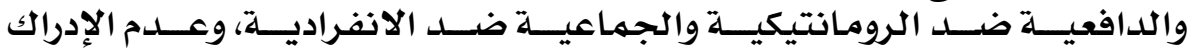

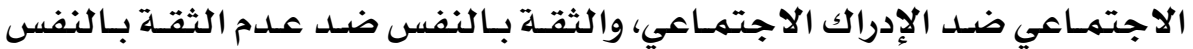

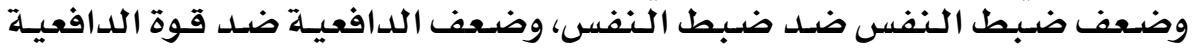

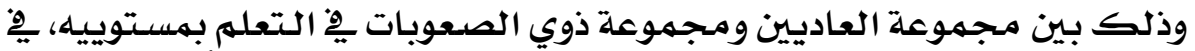

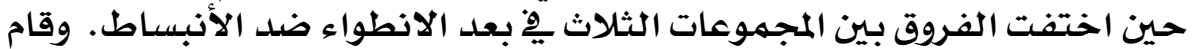

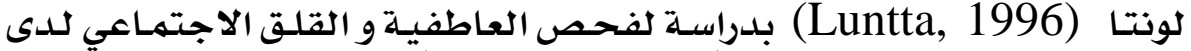

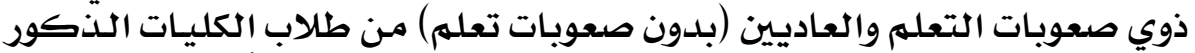

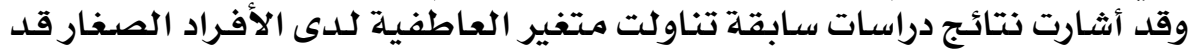

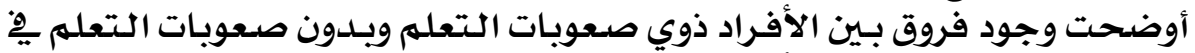

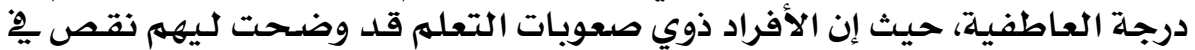

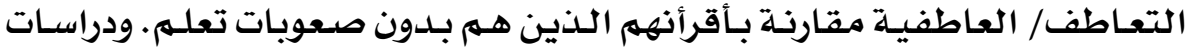

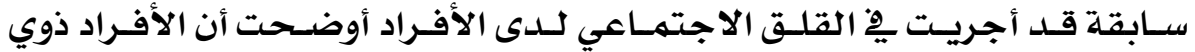

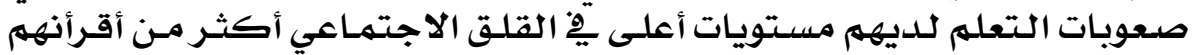

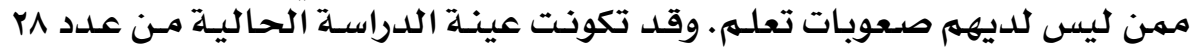

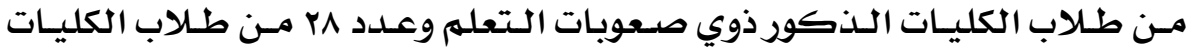

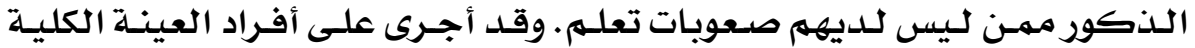

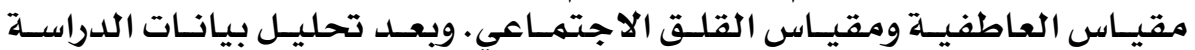

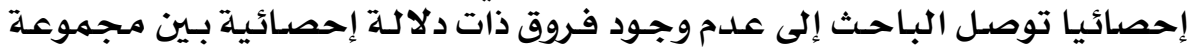

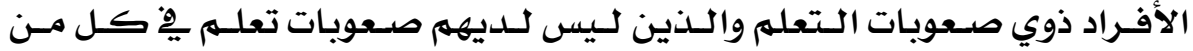

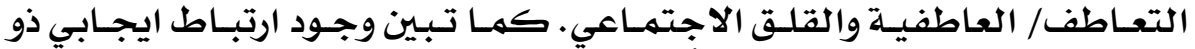

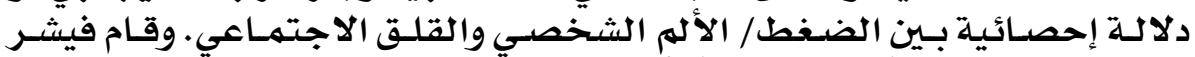

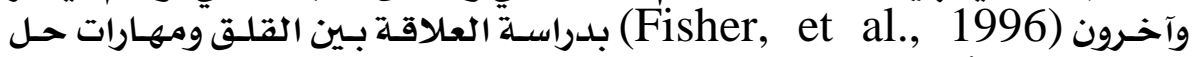

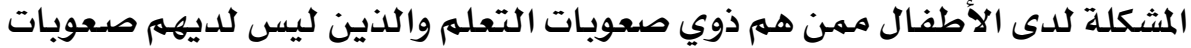

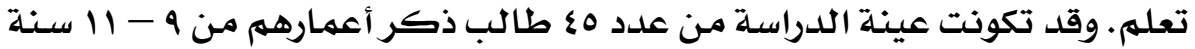

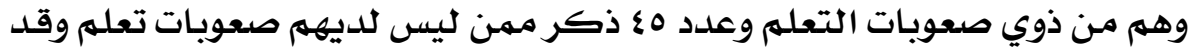

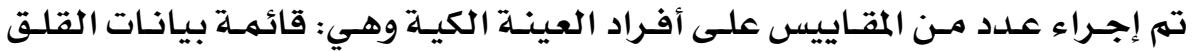

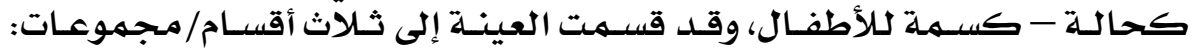

\section{YV 7}

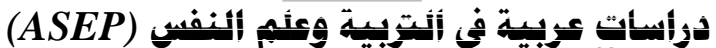




\section{المجلى الخاهس .. العقد الأول .. بيناير .. 1ا•مه}

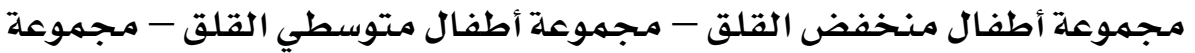

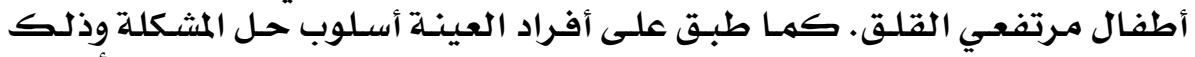

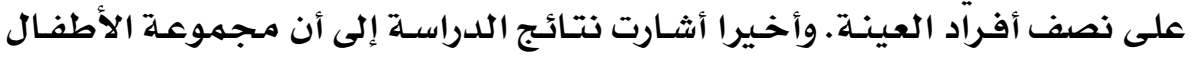

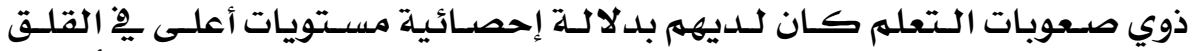

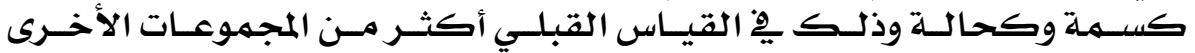

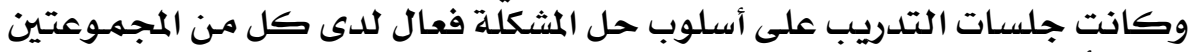

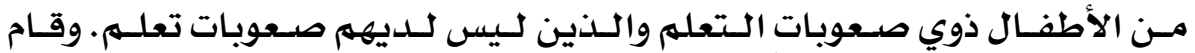

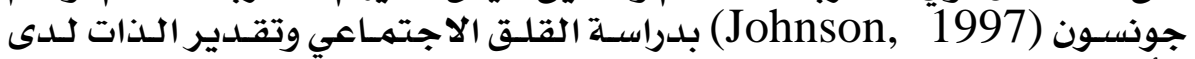

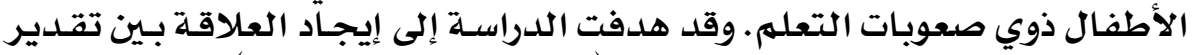

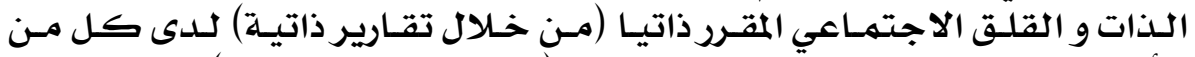

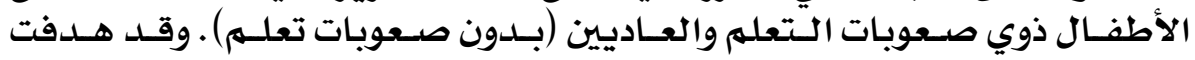

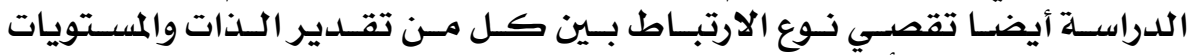

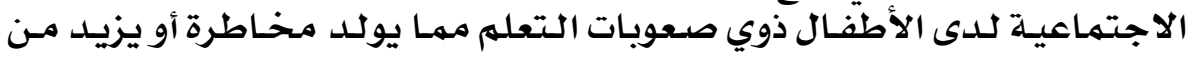

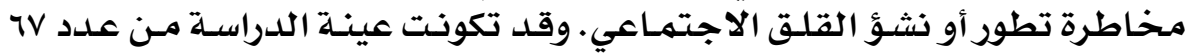

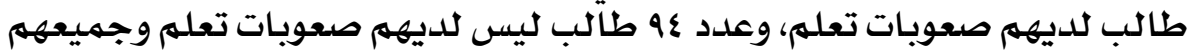

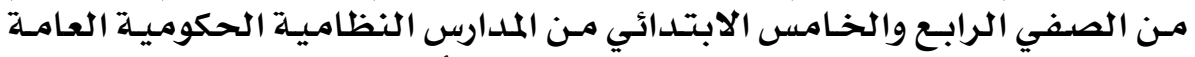

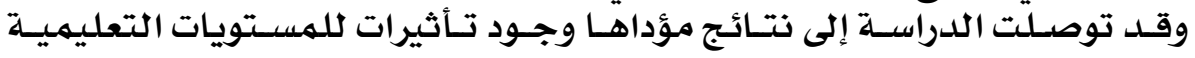

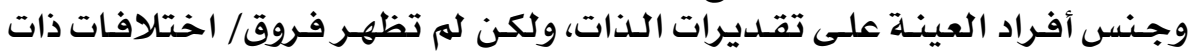

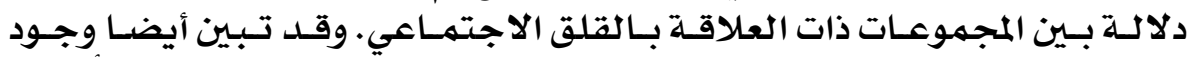

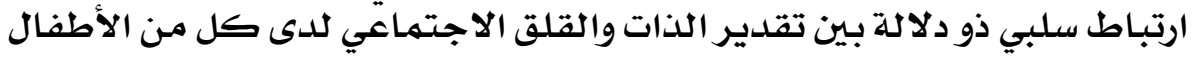
ذوي صعوبات التعلم ويدون صعوبات التعلم.

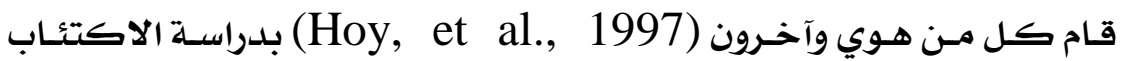

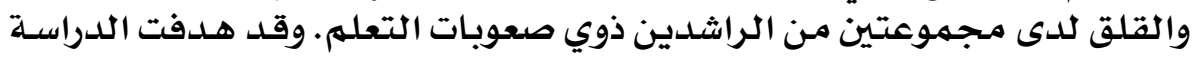

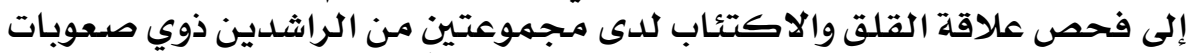

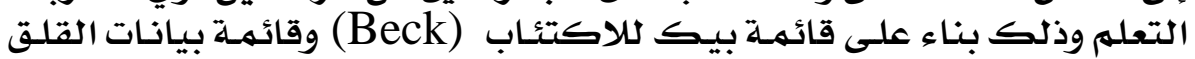

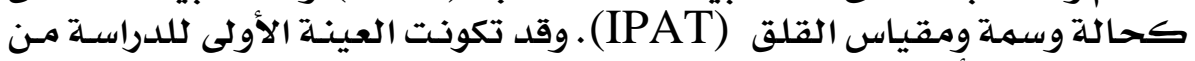

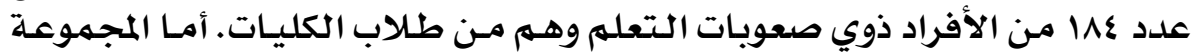

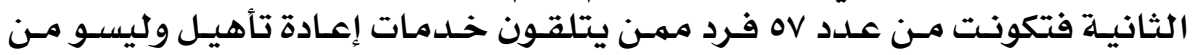

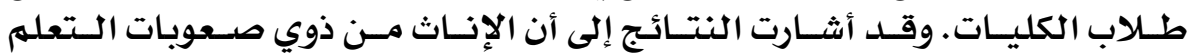

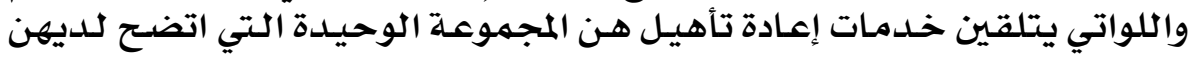

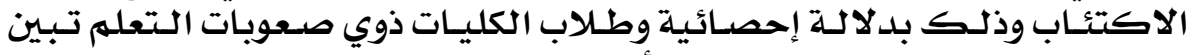

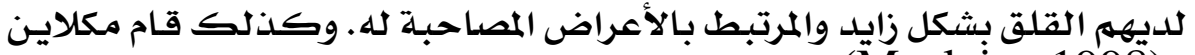

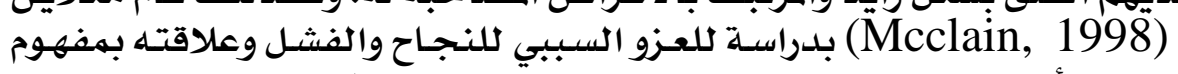

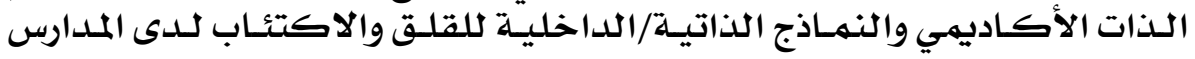

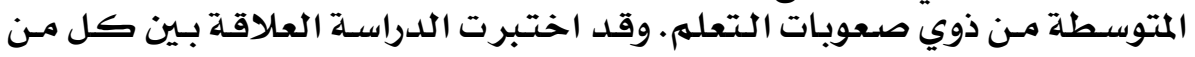

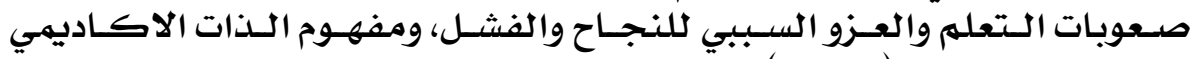
والمشكلات الداخلية (الذاتية) للقلق والاكتئياب وقد أشارت نتائج الدراسـة إلى أن الني

\section{YVV}

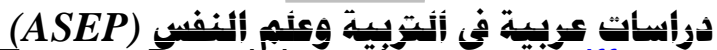




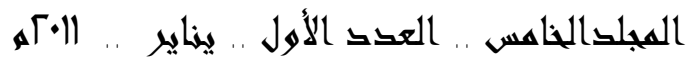

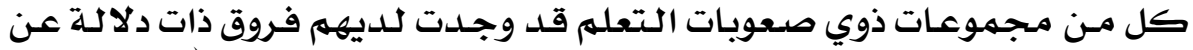

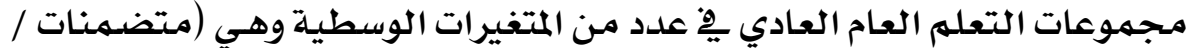

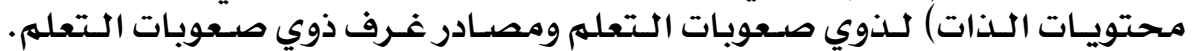

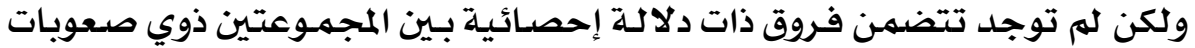

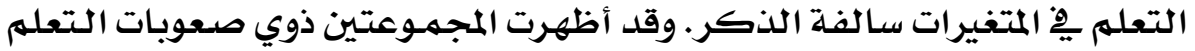

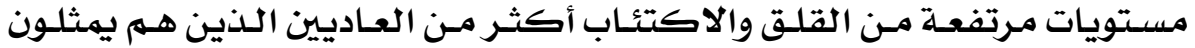

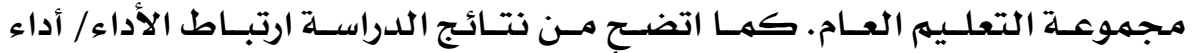

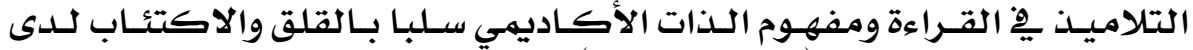

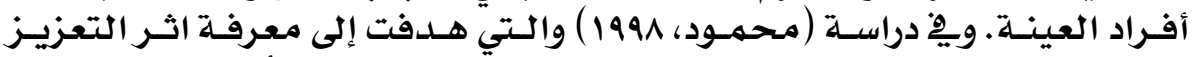

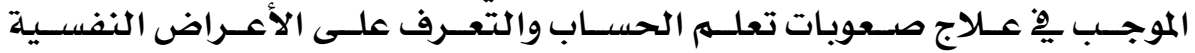

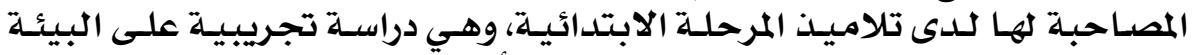

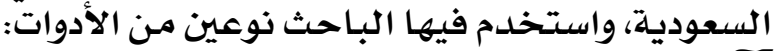

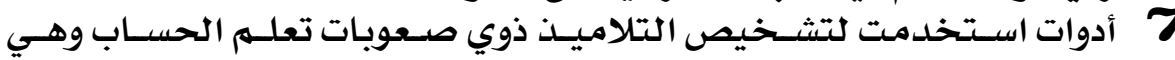

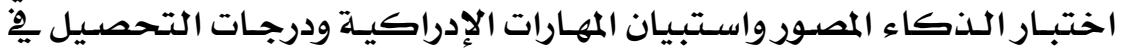

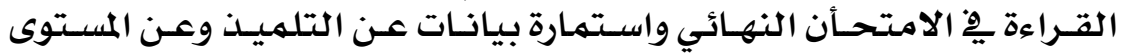

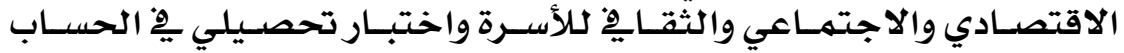
واسع الملدى.

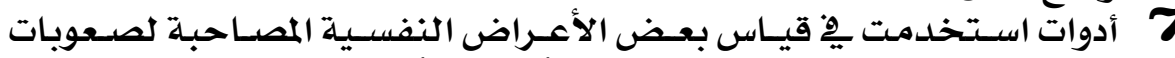

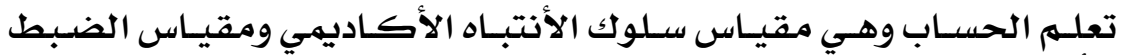

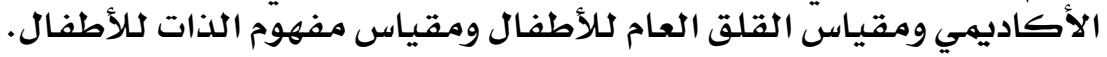

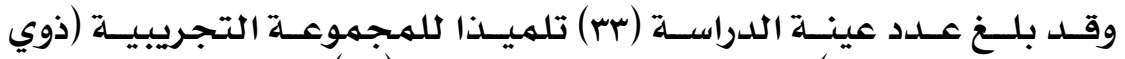

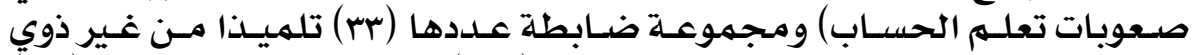

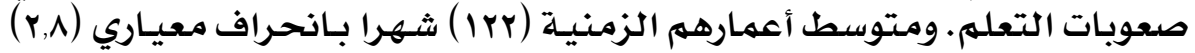

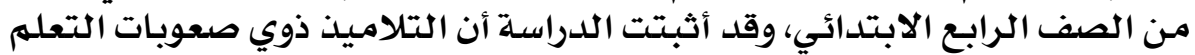

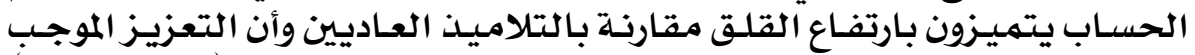

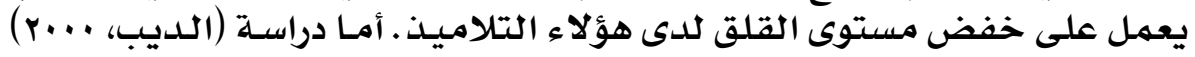

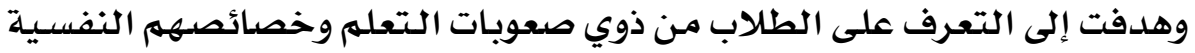

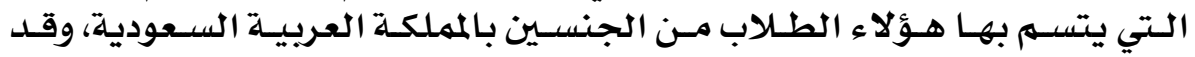

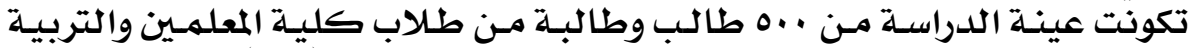

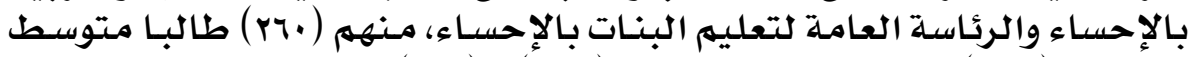

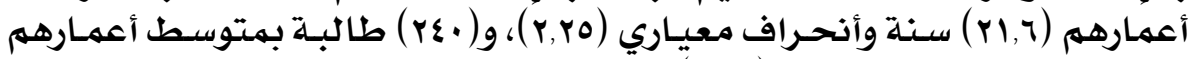

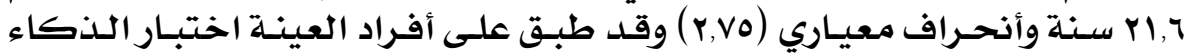

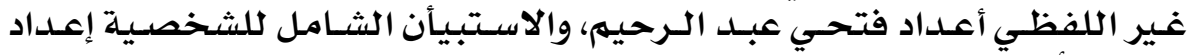

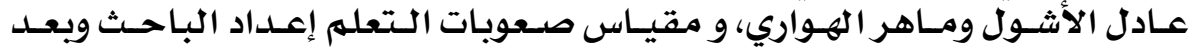

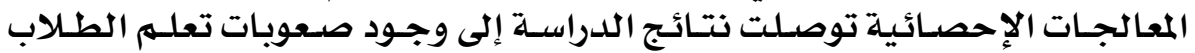

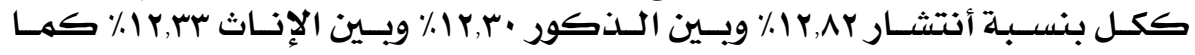

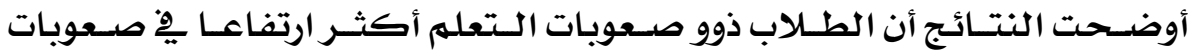

\section{YVA}

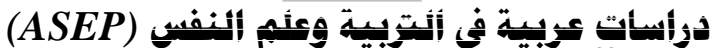




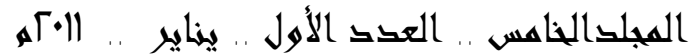

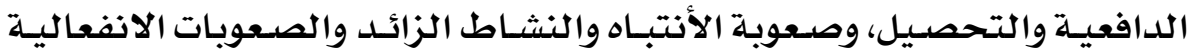

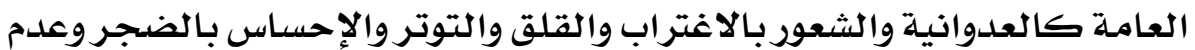
الثقة بالنفس.

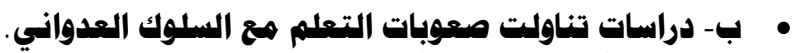

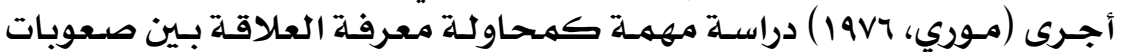

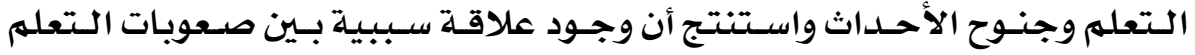

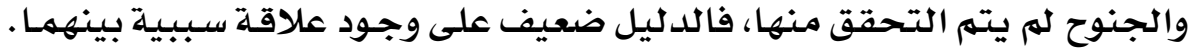

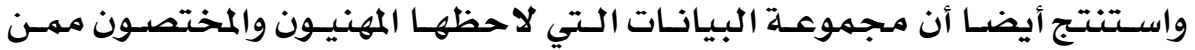

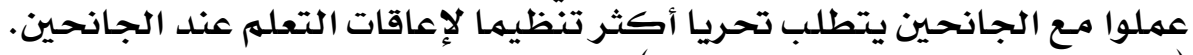

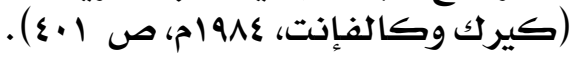

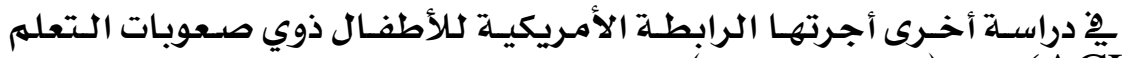
(ACLLD)

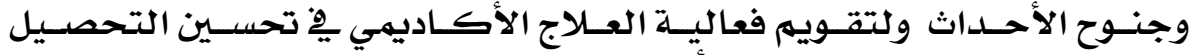

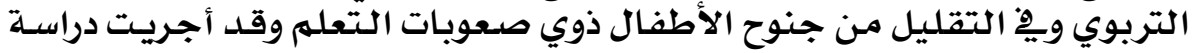

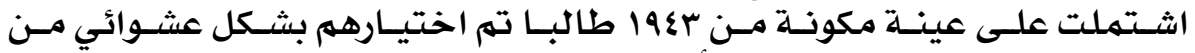

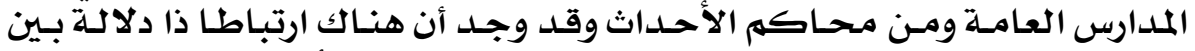

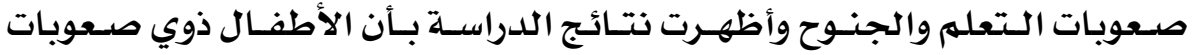

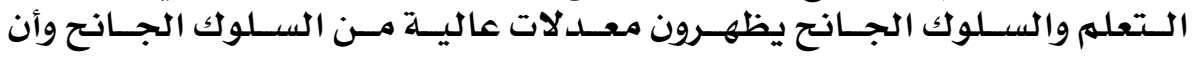

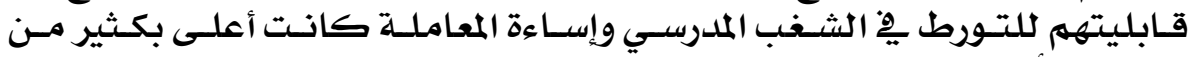

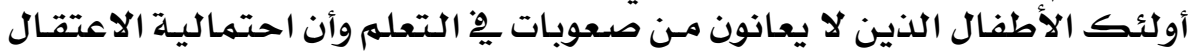

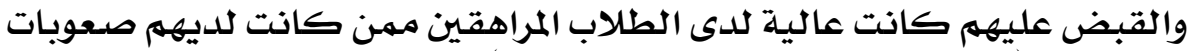

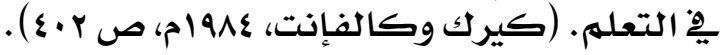

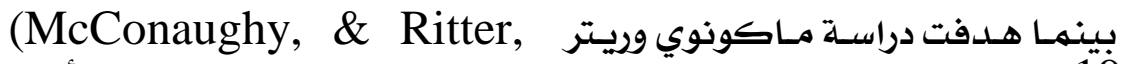

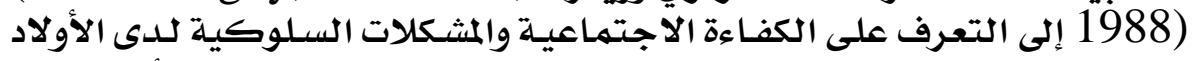

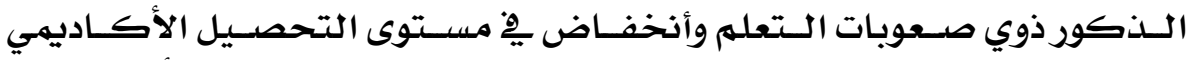

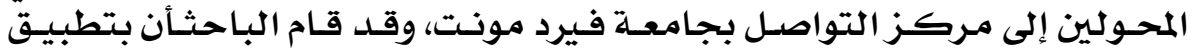

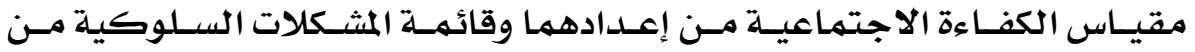

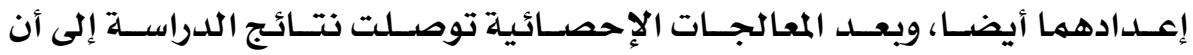

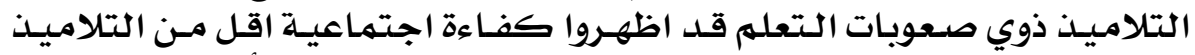

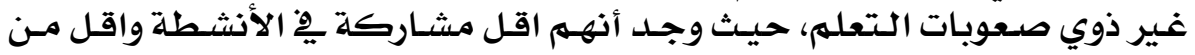

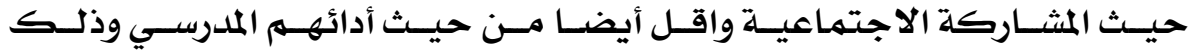

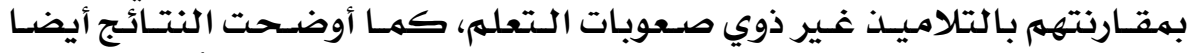

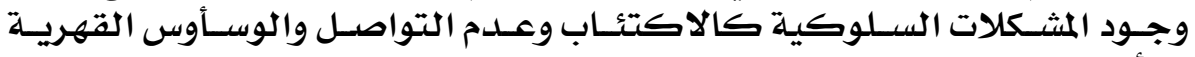

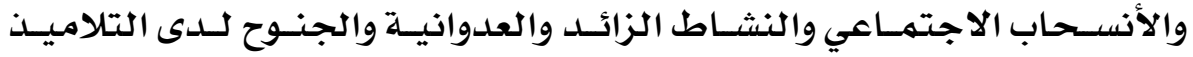

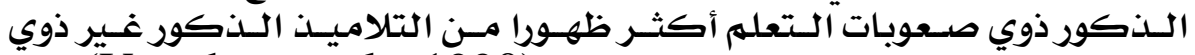

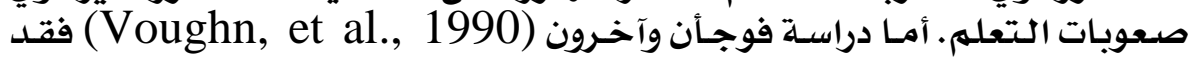

\section{YVq}




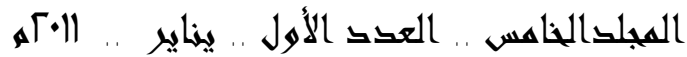

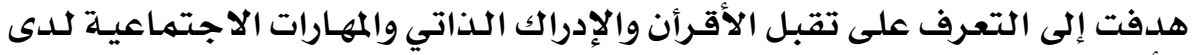

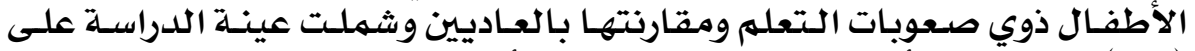

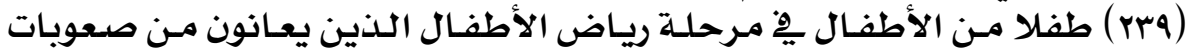

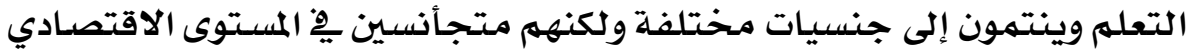

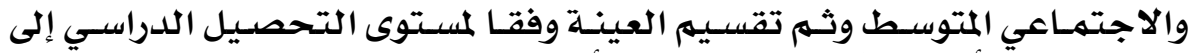

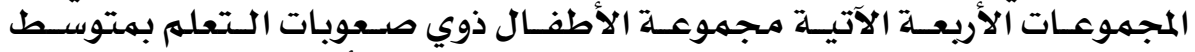

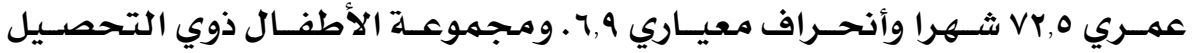

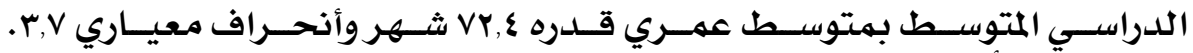

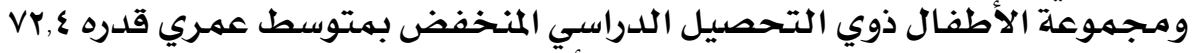

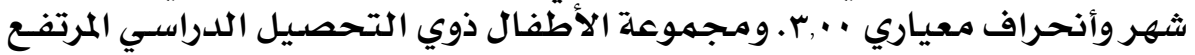

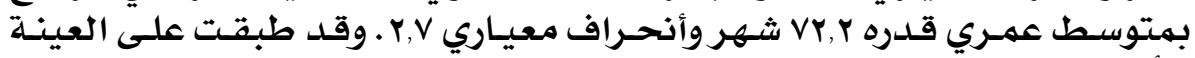

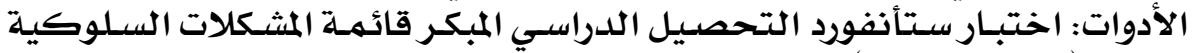

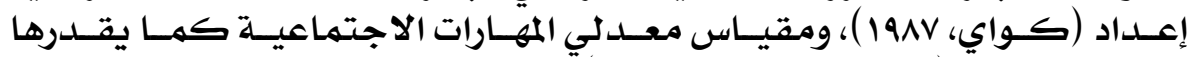

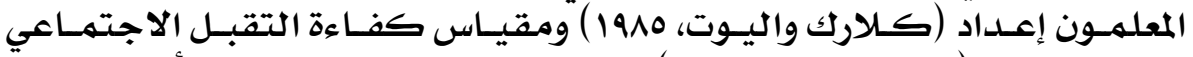

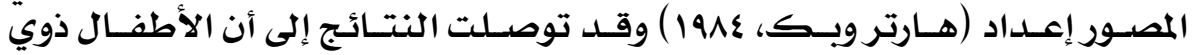

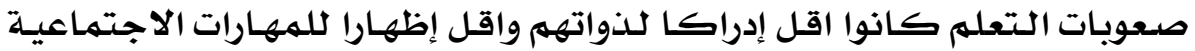

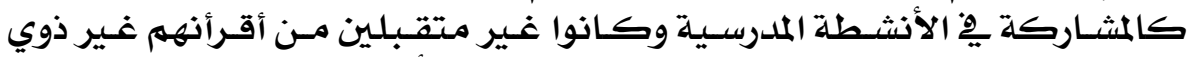

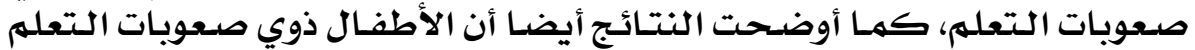

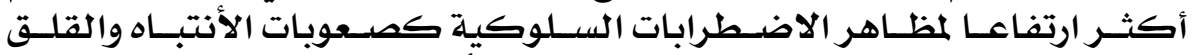

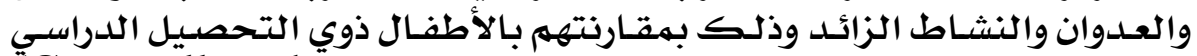

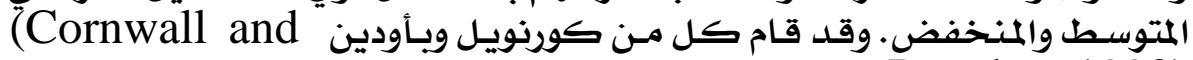

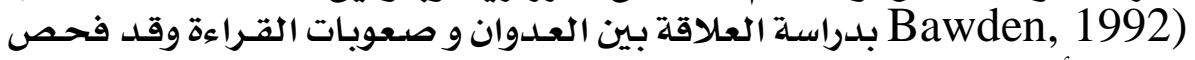

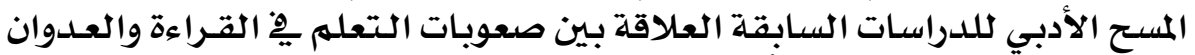

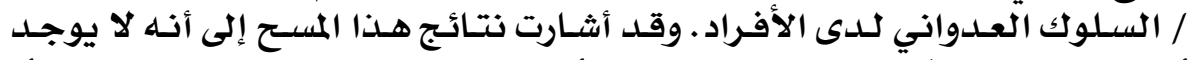

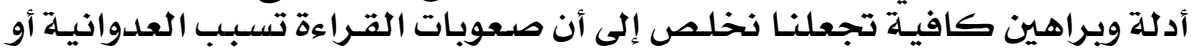

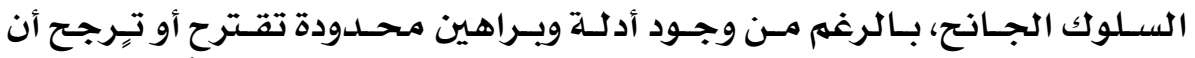

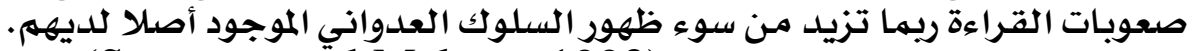
وكذذك دراسـة سوأنسـن ومـالوني (Swanson, añ

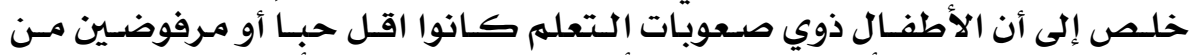

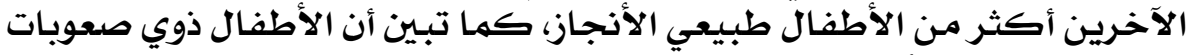

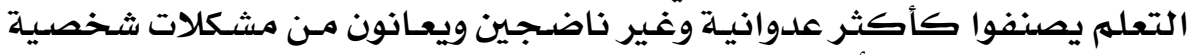
ولديهم صعوبات يخ الأنتباه.

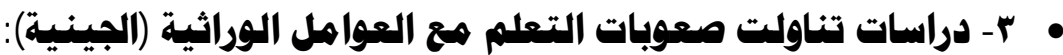

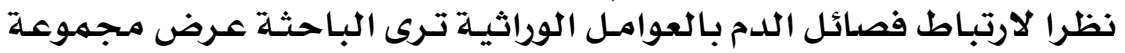

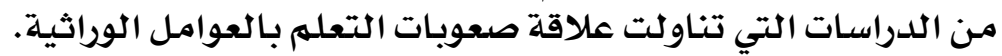

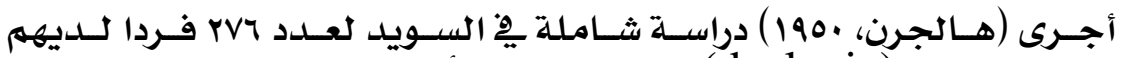

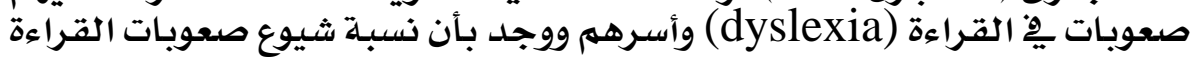

\section{Y^}


المجلى للخاهس .. العك الأول .. يناير .. التمه

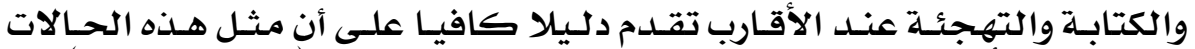

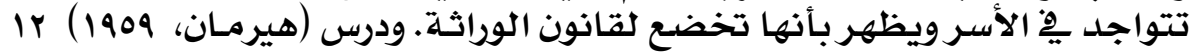

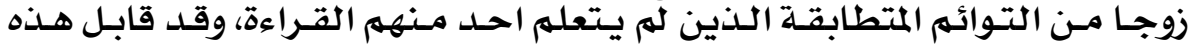

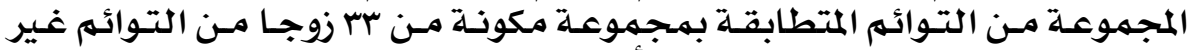

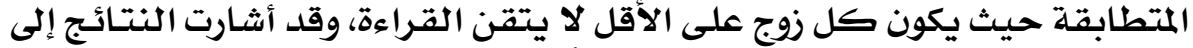

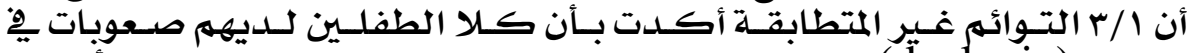

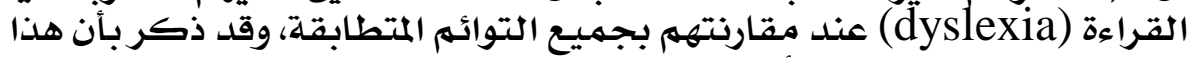

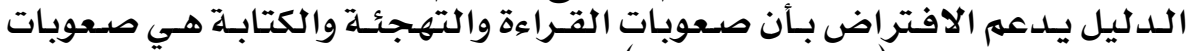

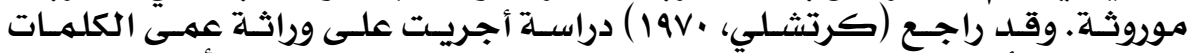

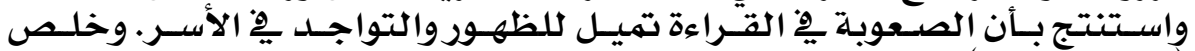

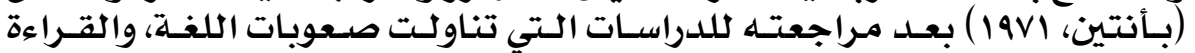

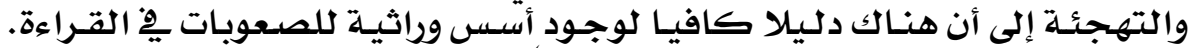

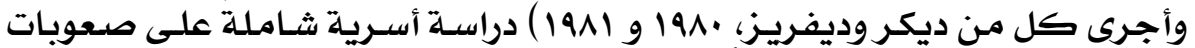

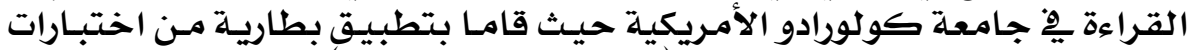

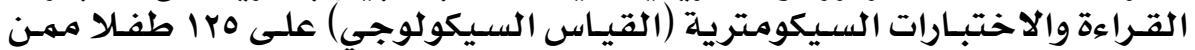

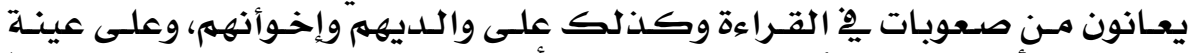

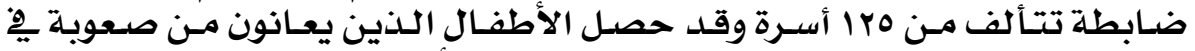

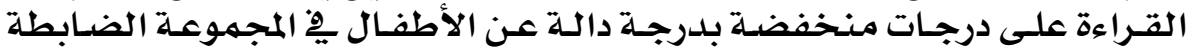

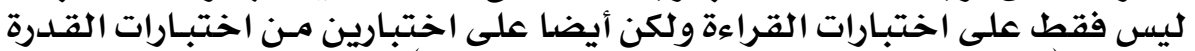

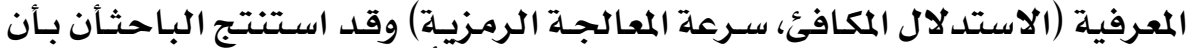

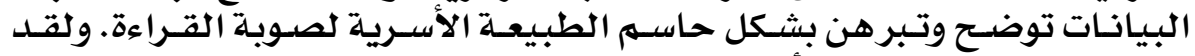

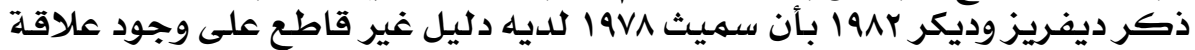

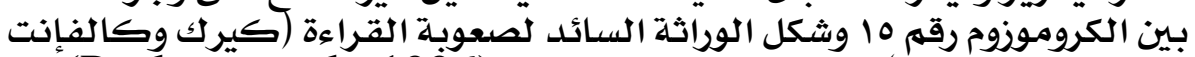

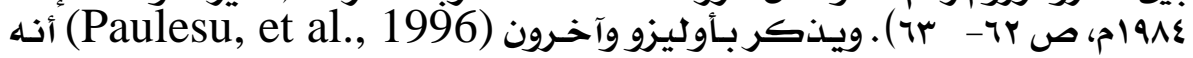

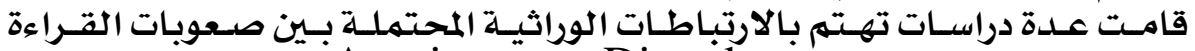

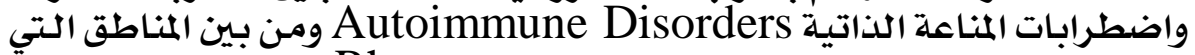

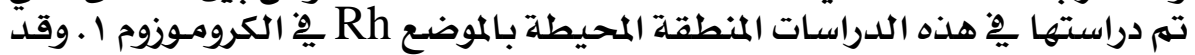

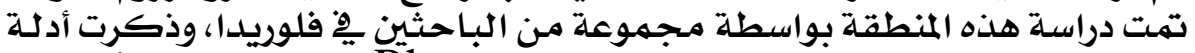

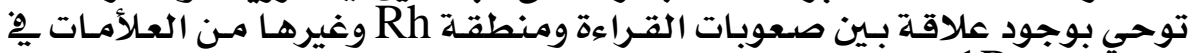

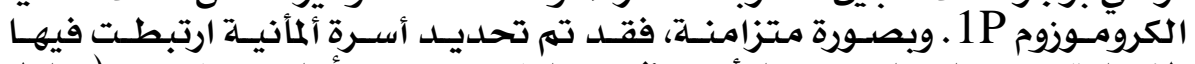

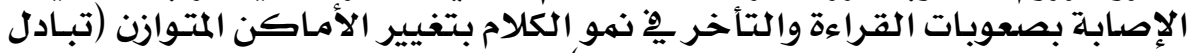

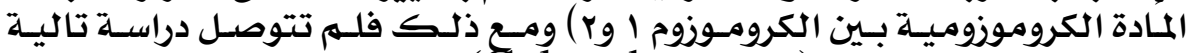

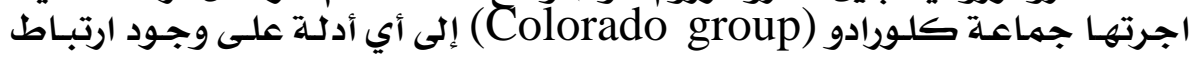

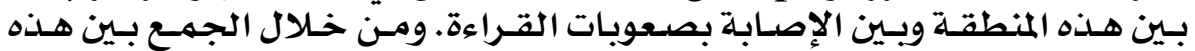

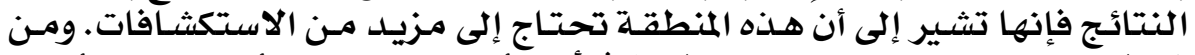

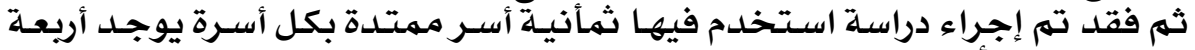

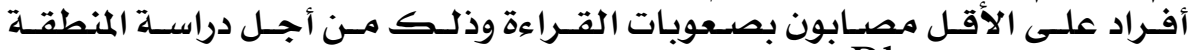

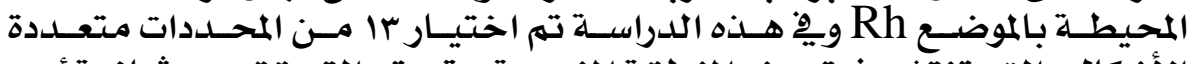

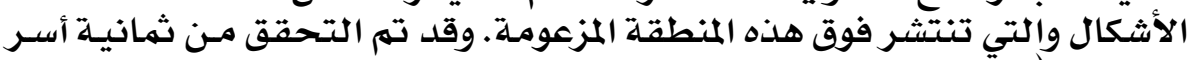

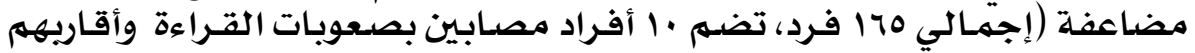




\section{المجلى الخاهس .. العقد الأول .. بيناير .. 1ا•مه}

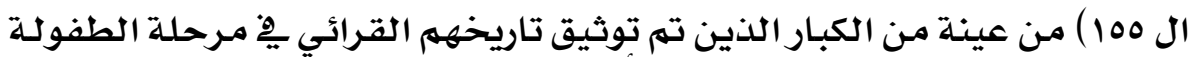

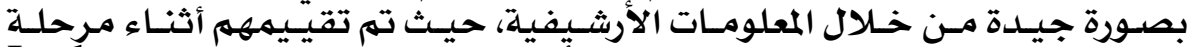

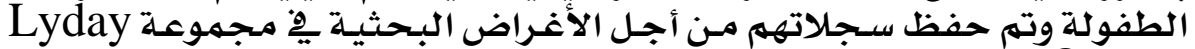

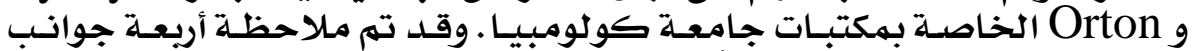

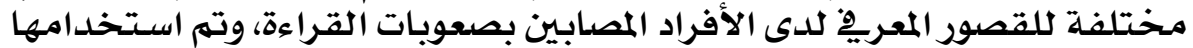

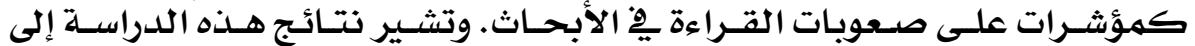

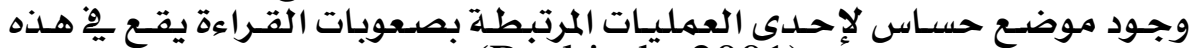

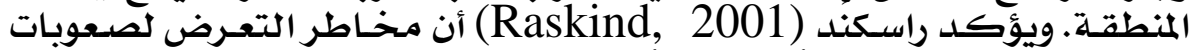

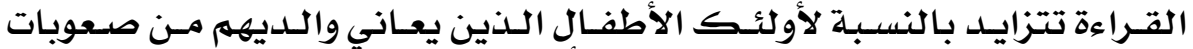

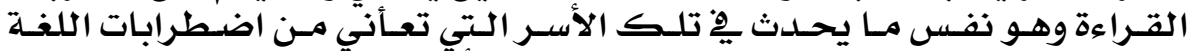

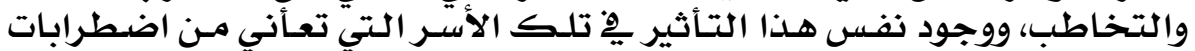

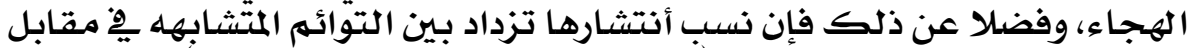

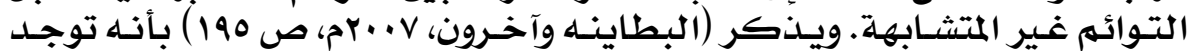

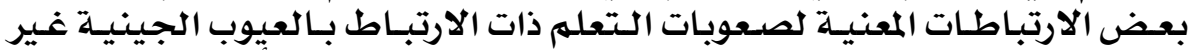

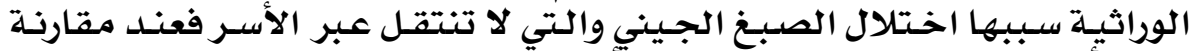

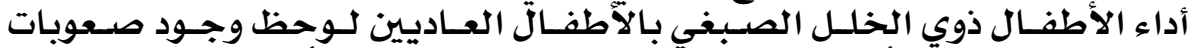

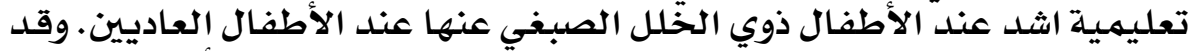

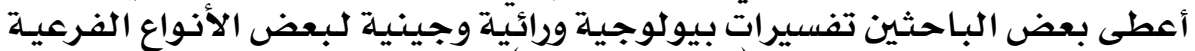

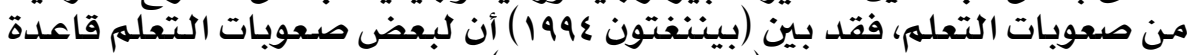

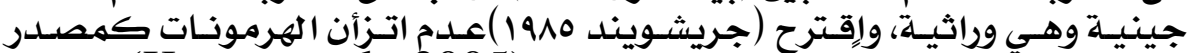

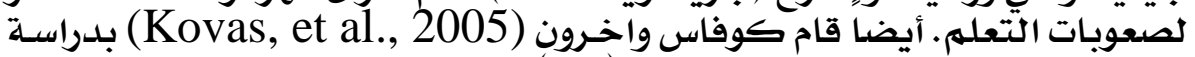

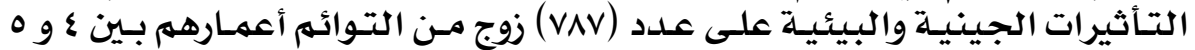

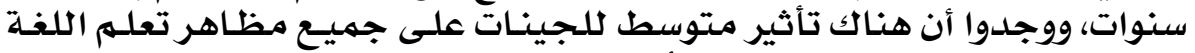

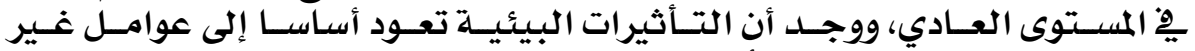

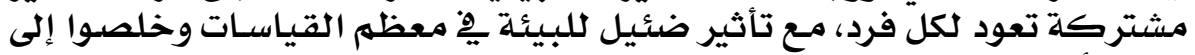

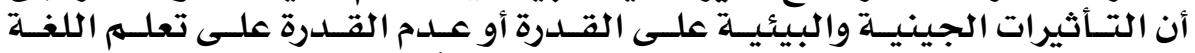

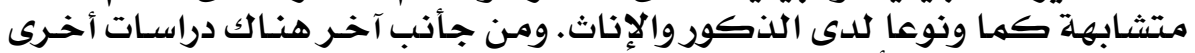

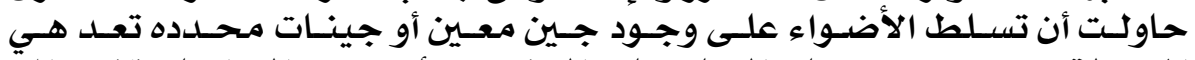

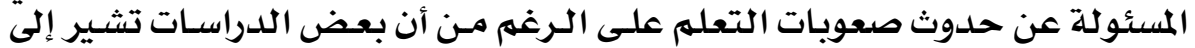

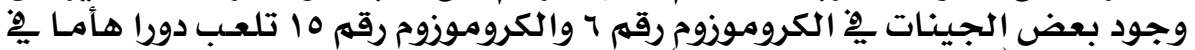

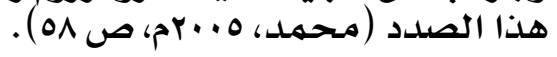

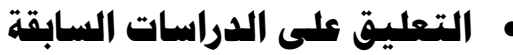

من خلال استعراض الباحثة للدراسات السابقة وجلدة البات ما يلي:

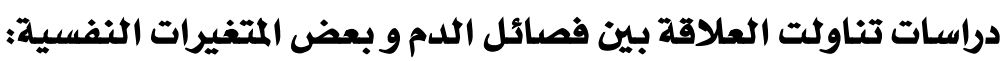

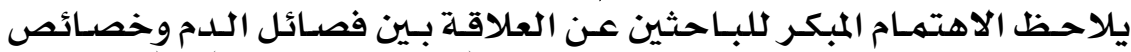

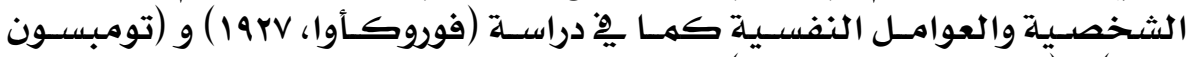

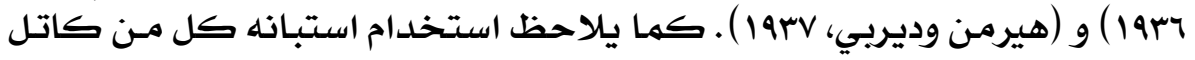

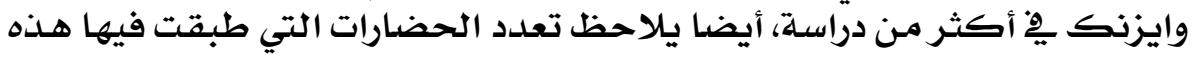




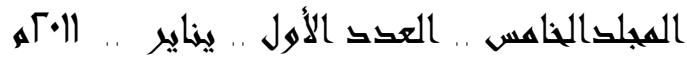

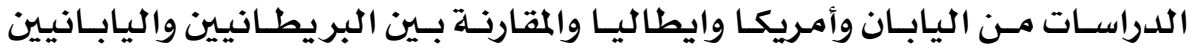

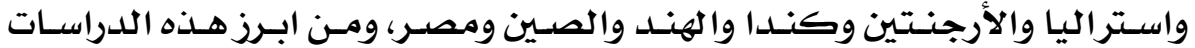

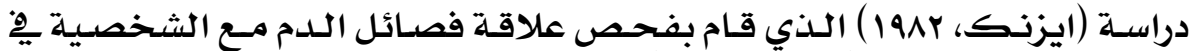

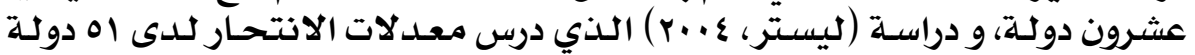

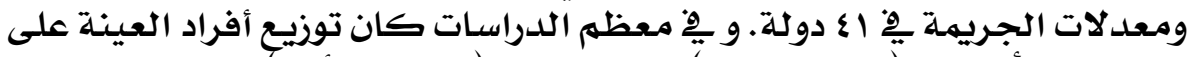

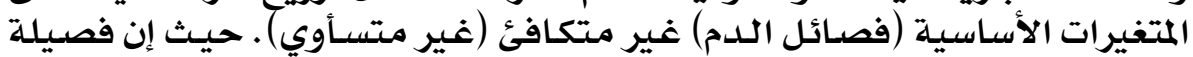

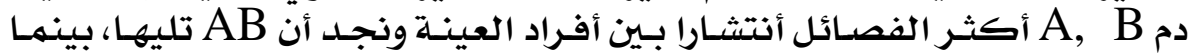

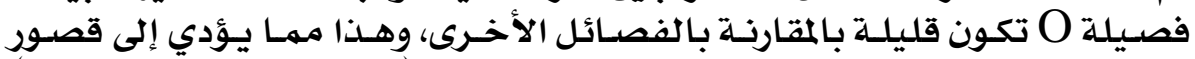

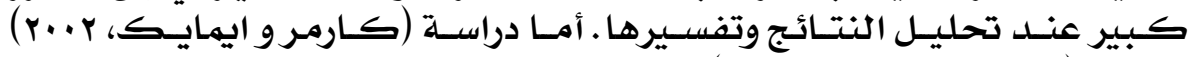

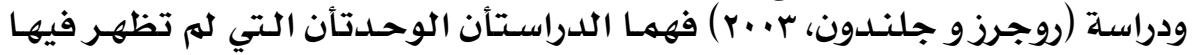

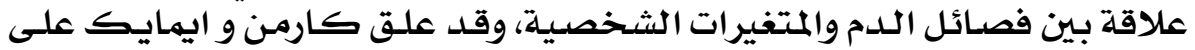

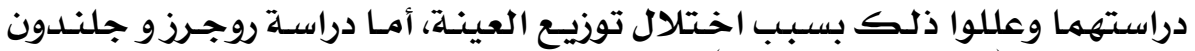

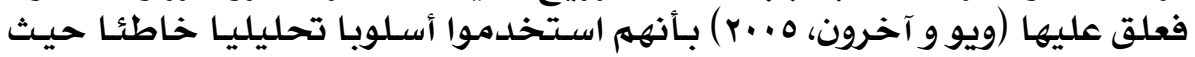

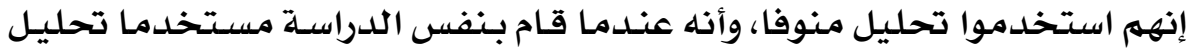

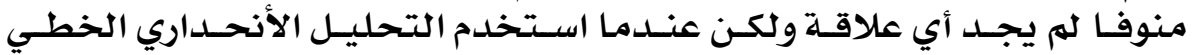

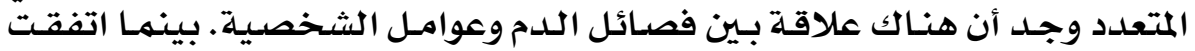

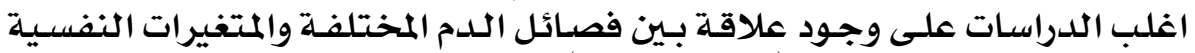

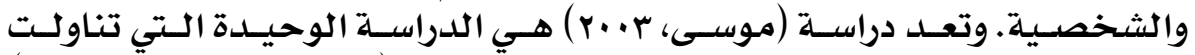

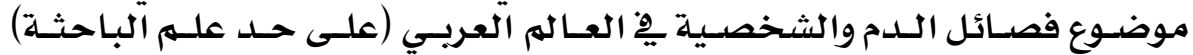

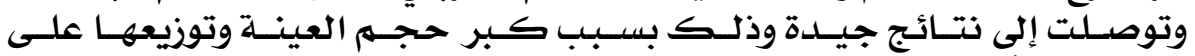

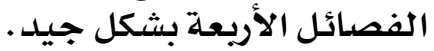

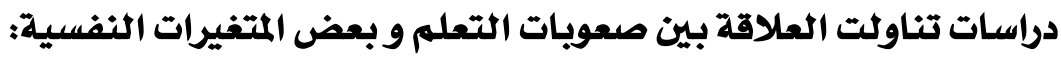

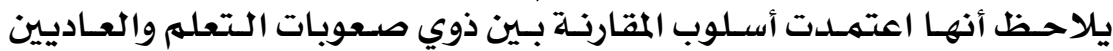

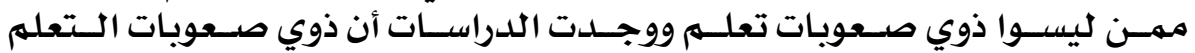

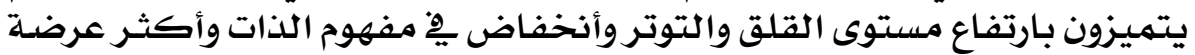

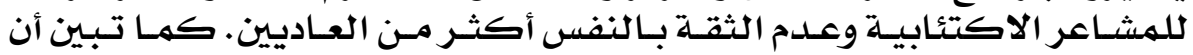

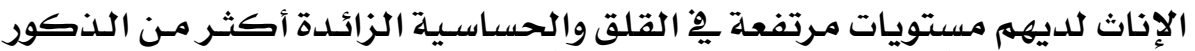

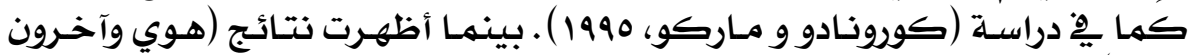

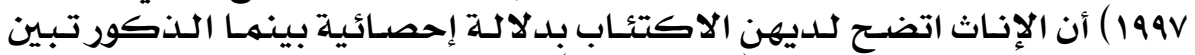

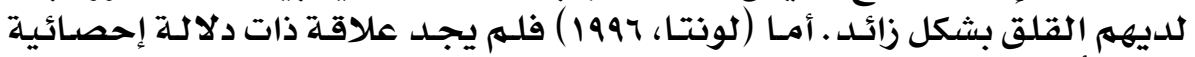

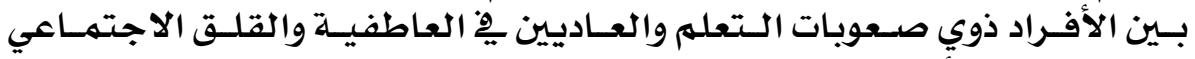

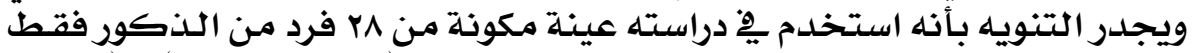

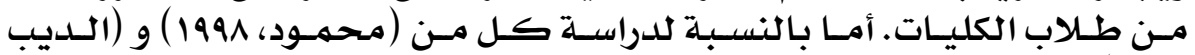

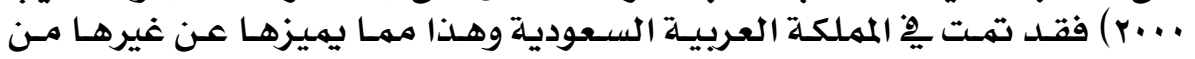

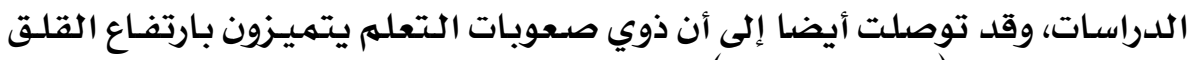

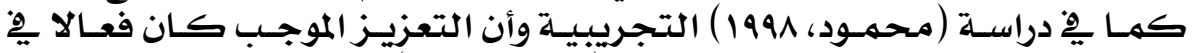

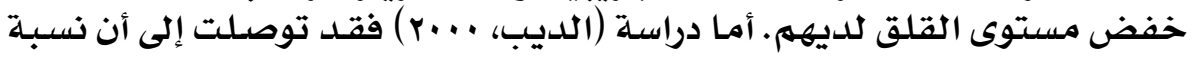

\section{$Y \wedge Y$}




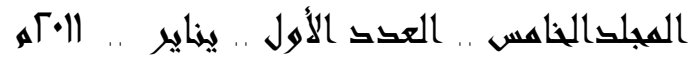

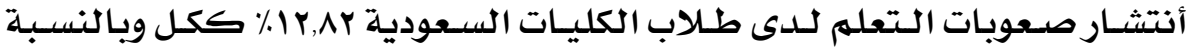

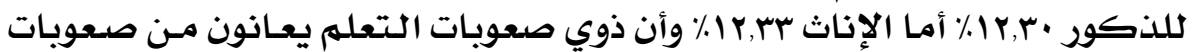

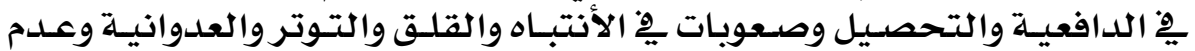

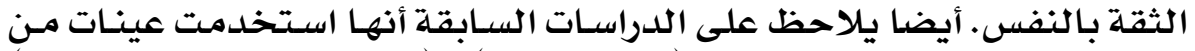

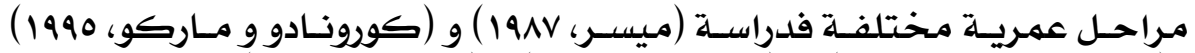

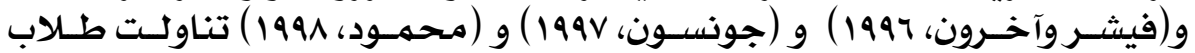

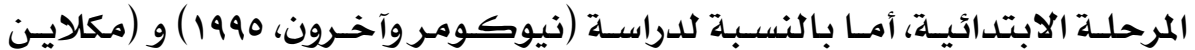

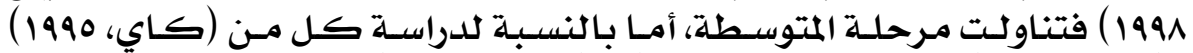

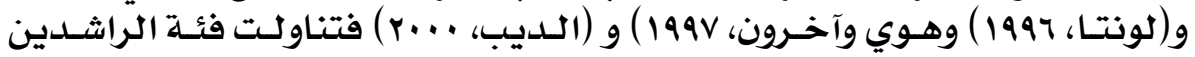

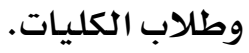

دراسات تناولت العلاقة بين صعوبات التهات التعلم والسلوثك العدواني:

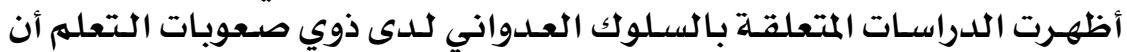

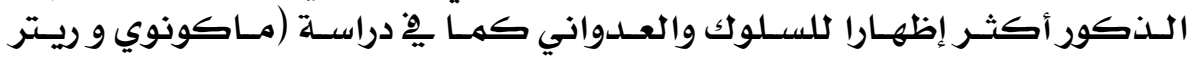

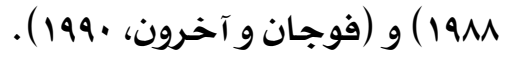

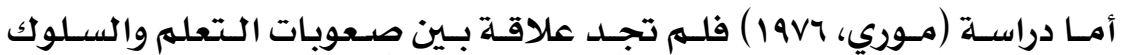

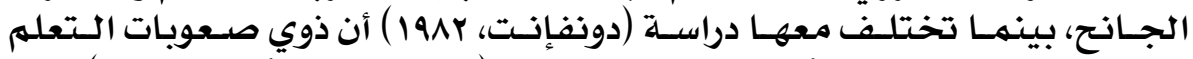

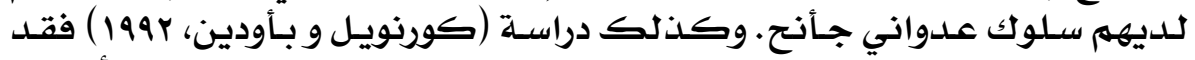

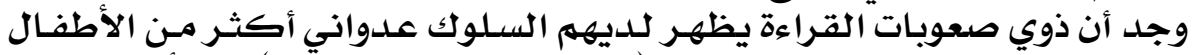

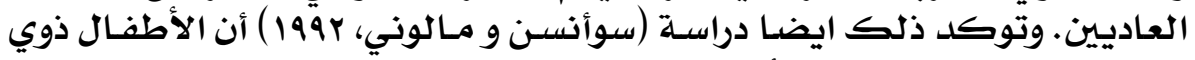

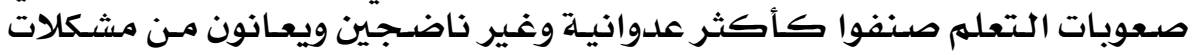

شخصية.

دراسات تناولت العلاقة بين صعوبات التعلم و العوامل الوراثية:

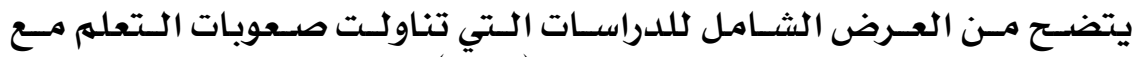

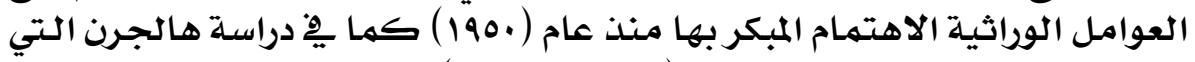

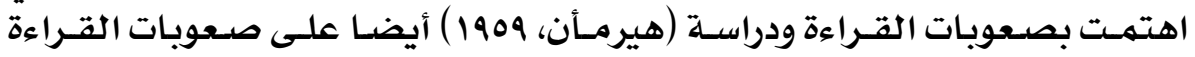

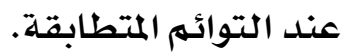

أيضا يلاحظ على جميع الدراسـات أنها اتفقت على كون كون صعوبات التعلهم تعود إلى تأثيرات جينينة وراثية.

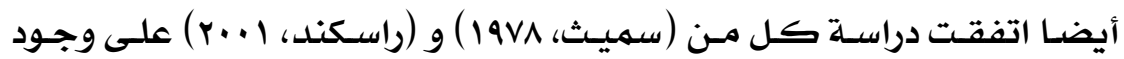

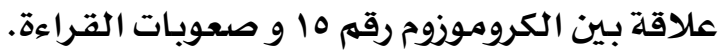

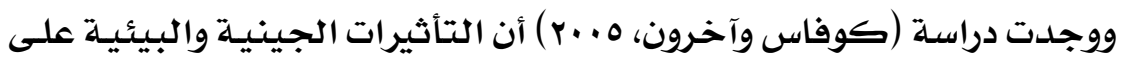

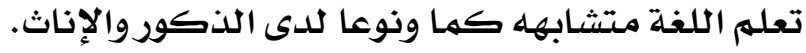

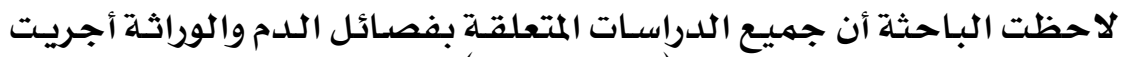

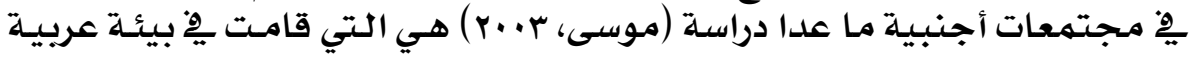

\section{$Y \wedge \varepsilon$}




\section{المجلى الخاهس .. العقد الأول .. بيناير .. 1ا•مه}

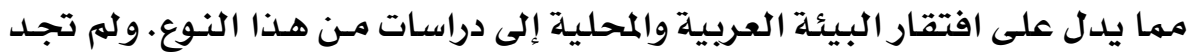

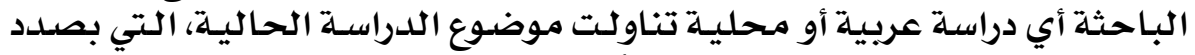

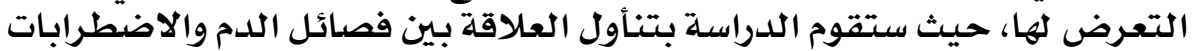

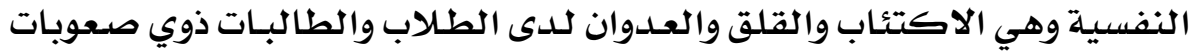
التعلم والعاديين يِّ المرحلة الابتدائية.

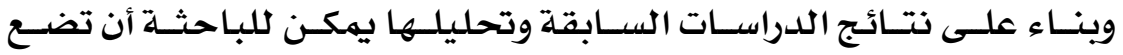

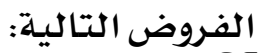

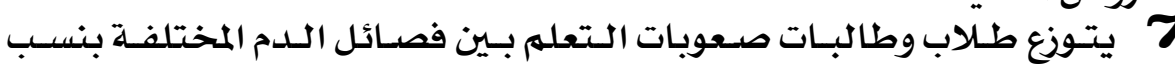

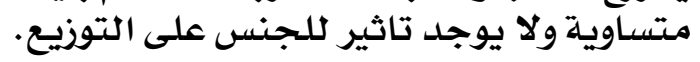

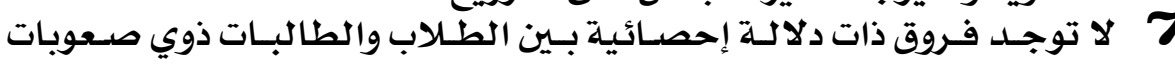

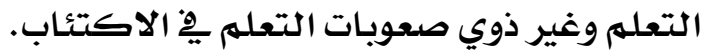

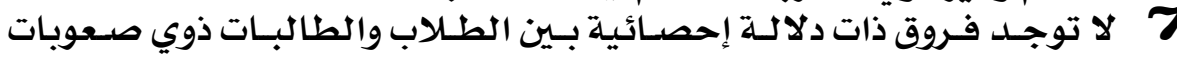

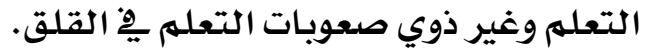

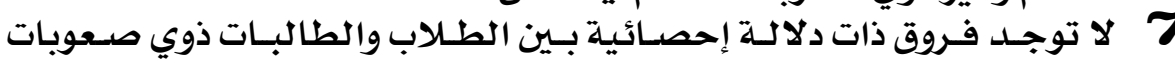
التعلم وغير ذوي صعوبات التعله يو إن العدوان.

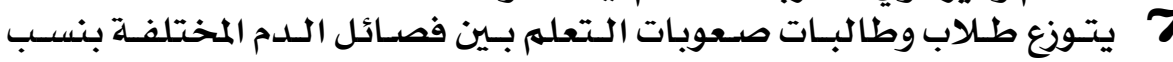

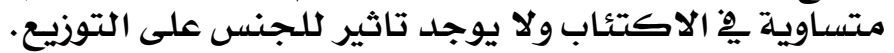

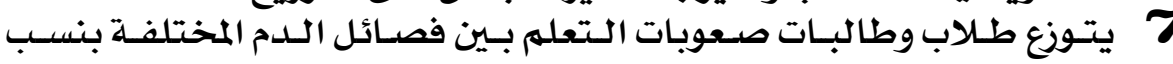

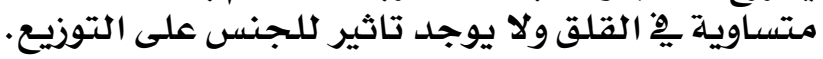

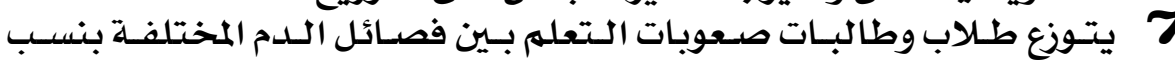

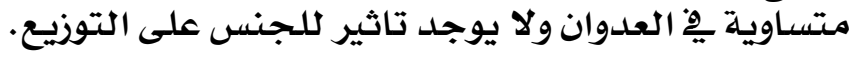

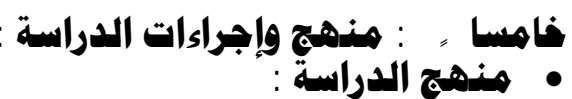
اسـتخدمت الباحثـة المـنهج الوصـي ألارتبـاطي والمقـارن لملاءمتـه لطبيعـة

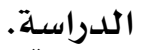

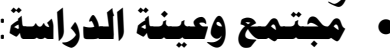

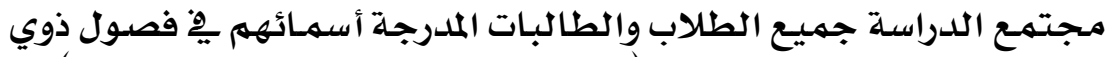

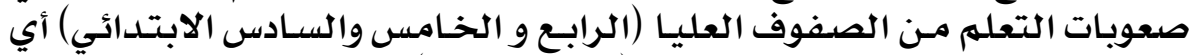

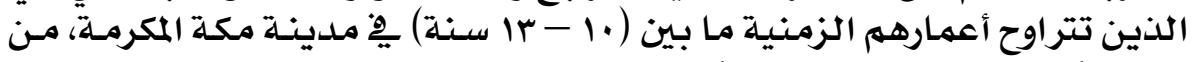

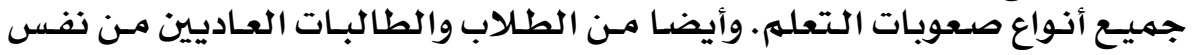
المرحلة التعليمية الذين ليس لديهم صعوبات التيات تعلهم.

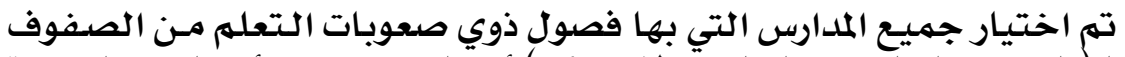

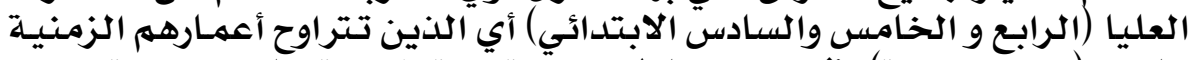

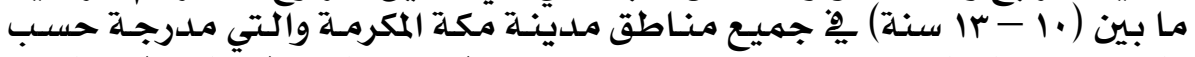

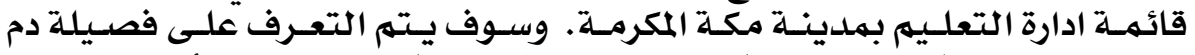

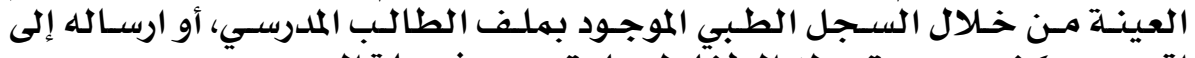

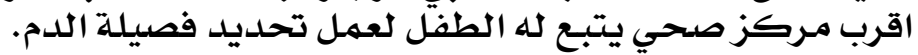

\section{Y^०}




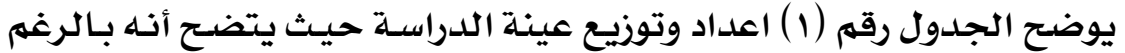

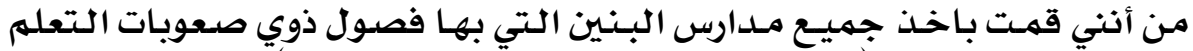

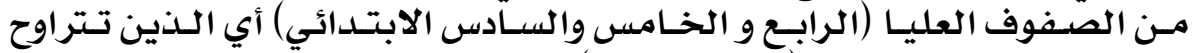

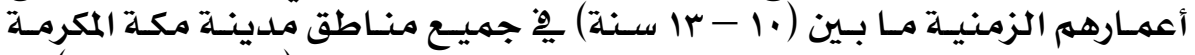

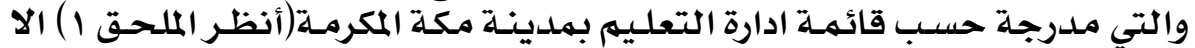

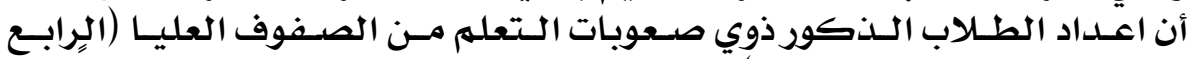

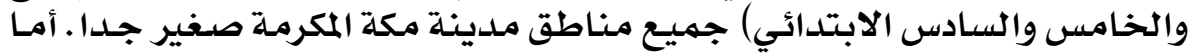

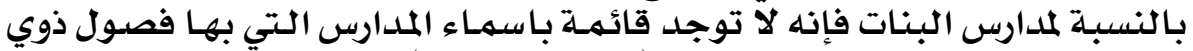

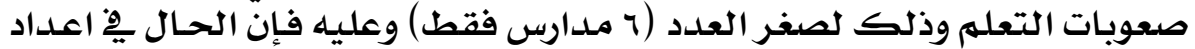

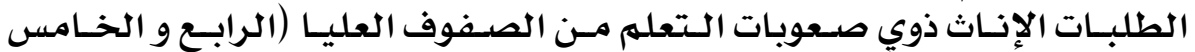

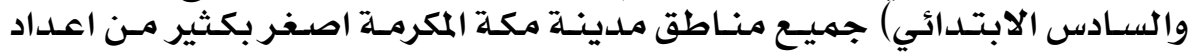

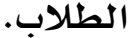

جدول رقم (1): اعداد الطلاب والطالبات ذوي صعوبات التعلم والعاديين من الصفوف العليا

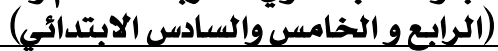

\begin{tabular}{|c|c|}
\hline VI & 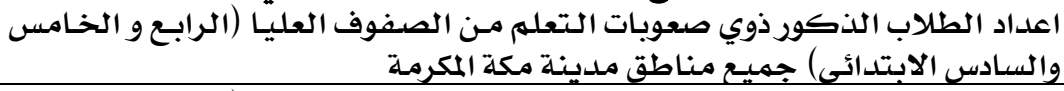 \\
\hline 19 & 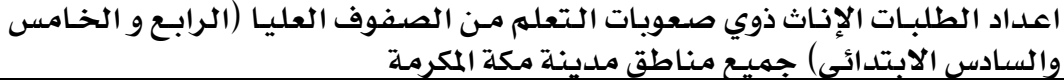 \\
\hline YQ7 & الاعتداد الطيلى) ابلاب الدذكور العـاديـين مـن الصفوف العليـا (الرابع و الخـامس والسـادس \\
\hline $1 Y 7$ & 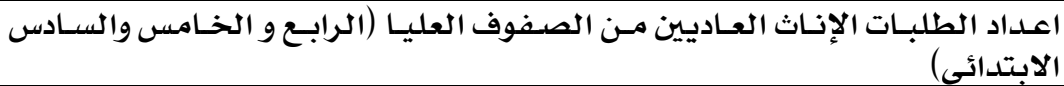 \\
\hline
\end{tabular}

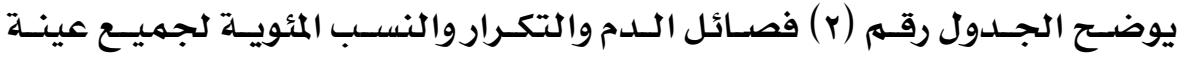

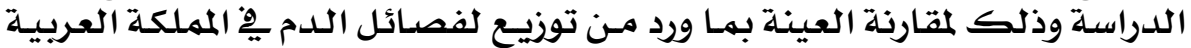

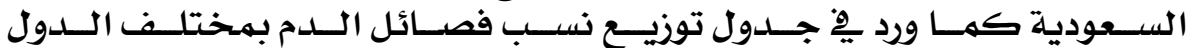

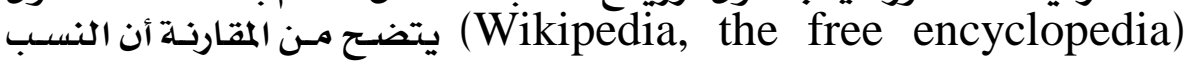

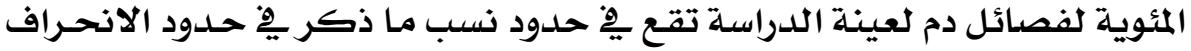

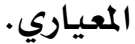

جدول رقم (Y) : فصائل الدم والتكراروالنسب المثوية لجميع عينة الدراسة

\begin{tabular}{|c|c|c|c|c|}
\hline \multicolumn{2}{|c|}{ 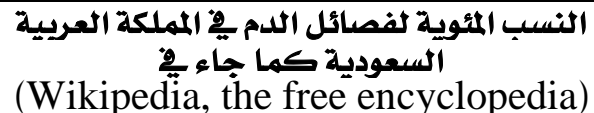 } & \multirow[t]{2}{*}{ المئوية } & \multirow[t]{2}{*}{ التكرار } & \multirow[t]{2}{*}{ فصيلة } \\
\hline الانحراف المعياري & النسبية المئوية & & & \\
\hline 7.1 & 26 & 31.1 & 161 & $\mathrm{~A}$ \\
\hline 2.2 & 4 & 2.5 & 13 & $\mathrm{AB}$ \\
\hline 6.8 & 18 & 16.6 & 86 & B \\
\hline 7.5 & 52 & 49.7 & 257 & $\mathrm{O}$ \\
\hline & 100.0 & 100.0 & 517 & المجموع \\
\hline
\end{tabular}


المجلدالخاهس .. العقد الأول .. يناير .. المه

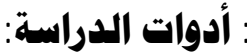

سوف تستخدم الباحثة الأدوات والمقاييس التالية:

$$
7
$$

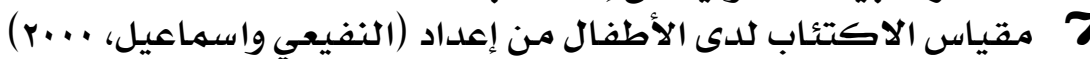

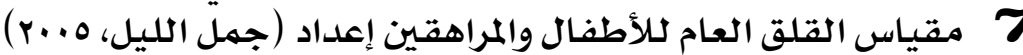

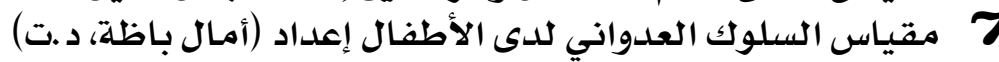

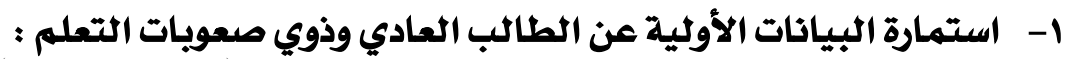

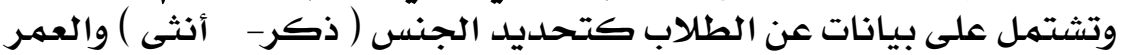

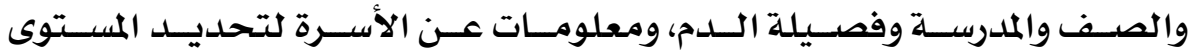

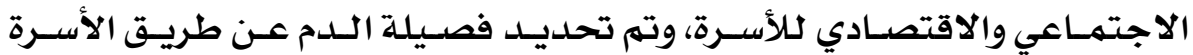

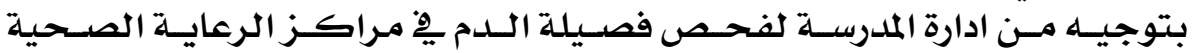

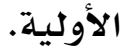

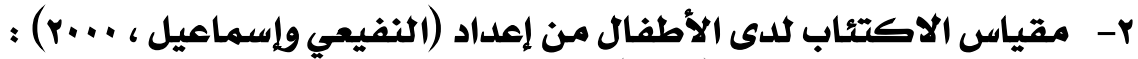

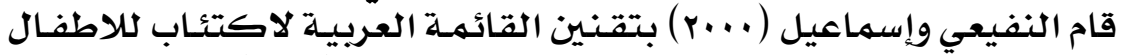

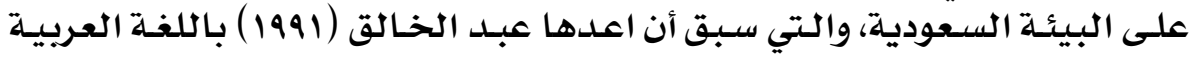

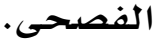

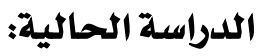

$$
7 \text { عينة الدراسة: }
$$

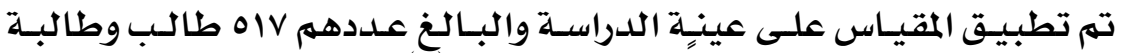

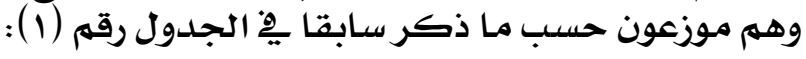

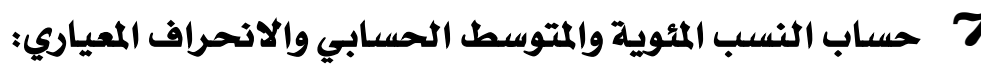

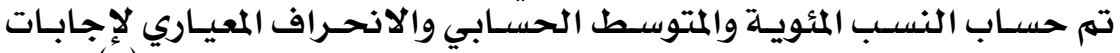

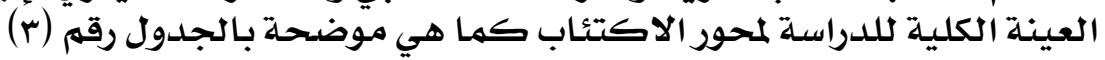
7

$$
7
$$

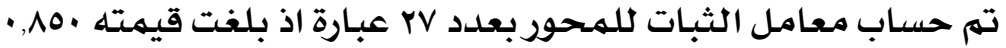
7 ثانيا: صدق الاتساق الداخلي:

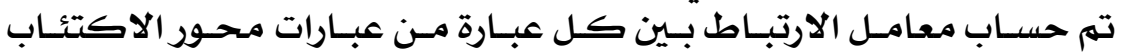

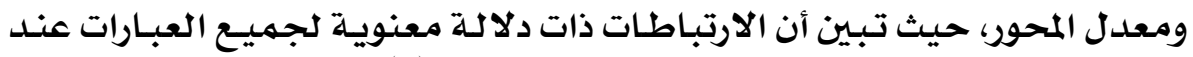

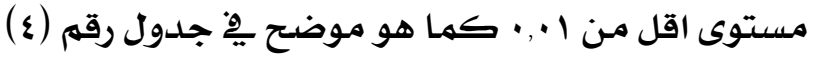

\section{YAV}


المجلى الخاهس .. العقد الأول .. يناير .. المه

جدول رقم (r): يوضح النسب المئوية والمتوسط الحسابي والانحراف المعياري لاجابات عينة الدراسة لمحور الاكتئاب المابل

\begin{tabular}{|c|c|c|c|c|c|}
\hline الانحيراف & الحتوسطي & يحثيرً & آحياناً & نيادراً & محور الاكتئاب \\
\hline .692 & 1.78 & 15.4 & 47.4 & 37.2 & أشعر بالغضب \\
\hline .735 & 1.69 & 16.4 & 36.7 & 46.9 & أنامجيدا' \\
\hline .673 & 1.69 & 12.0 & 45.4 & 42.6 & أشعر بـالممل_أنا زهقأنة \\
\hline .668 & 1.65 & 10.9 & 43.3 & 45.8 & هنالك أشياء كثيرة تضايقني \\
\hline .623 & 1.65 & 8.0 & 49.0 & 43.0 & أشعر بالتعب \\
\hline .630 & 1.62 & 8.0 & 45.6 & 46.4 & أشعر بـالسعادة \\
\hline .732 & 1.61 & 14.9 & 31.7 & 53.4 & أقلق أثناء النوم \\
\hline .672 & 1.55 & 10.2 & 35.1 & 54.7 & أنا سرحأنة \\
\hline .641 & 1.53 & 8.0 & 37.2 & 54.7 & أشعر بالضيق \\
\hline .610 & 1.53 & 6.1 & 40.9 & 53.0 & أشعر بالكسل \\
\hline .658 & 1.53 & 9.2 & 34.5 & 56.4 & أحله أحلأمـا مزعجلة \\
\hline .657 & 1.51 & 9.1 & 33.1 & 57.8 & أجد صعوبة ٍِِ التركيز على دراستى \\
\hline .694 & 1.50 & 11.6 & 26.9 & 61.6 & أنا واثقة من نفسى ل \\
\hline .710 & 1.49 & 12.6 & 23.7 & 63.6 & الحياة حلوة \\
\hline .683 & 1.47 & 10.8 & 25.8 & 63.4 & أنا راضية عن حياتى \\
\hline .638 & 1.46 & 7.9 & 30.2 & 61.9 & أنا حزينة \\
\hline .665 & 1.45 & 9.7 & 25.7 & 64.6 & كثير من الناس يحبونى \\
\hline .687 & 1.43 & 2.1 & 18.5 & 79.5 & لي أصدقاء كثيرون \\
\hline .637 & 1.43 & 8.0 & 26.6 & 65.4 & ستحلدث لى أشياء سيئة \\
\hline .655 & 1.41 & 9.3 & 22.7 & 68.0 & أما متفائلة_أتوقع الخير \\
\hline .626 & 1.41 & 7.5 & 25.7 & 66.9 & تركيزي ضعيف \\
\hline .661 & 1.40 & 9.8 & 20.7 & 69.5 & أشعر بـالوحدة_أننى وحيدة \\
\hline .627 & 1.38 & 7.9 & 22.0 & 70.1 & أشعر أننى تعيسـة \\
\hline .590 & 1.34 & 6.1 & 21.7 & 72.1 & أشعر أنى لاقيمة لى \\
\hline .596 & 1.34 & 6.5 & 20.8 & 72.7 & أنا متشائمة \\
\hline .529 & 1.26 & 4.4 & 17.1 & 78.5 & أكره نفسى \\
\hline .465 & 1.23 & 2.1 & 18.5 & 79.5 & أشعر أننى فاشلة \\
\hline
\end{tabular}

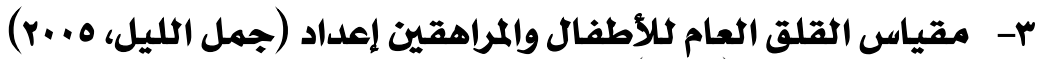

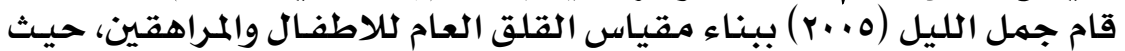

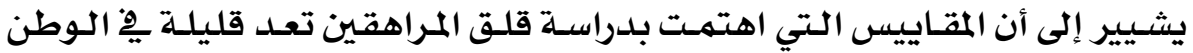

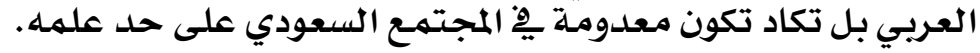

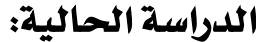 7}

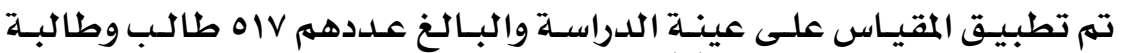

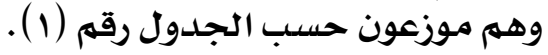

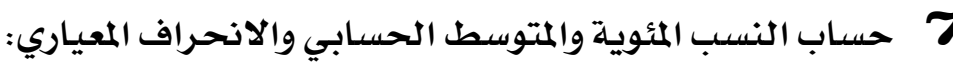

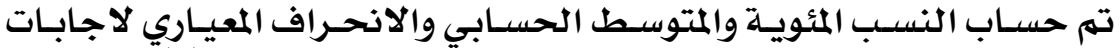

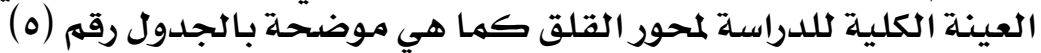

\section{$Y \wedge \Lambda$}

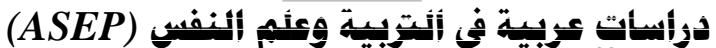


المجلى للخاهس .. العك الأول .. يناير .. الآم

جدول رقم (ع): يوضح قيمة معامل سبيرمان للارتباط ومستوى الدلالة

\begin{tabular}{|c|c|c|}
\hline مستوى الدلالة & معلامل سبيرمان & محور الاكتئاب \\
\hline .000 & $.438^{* *}$ & أشعر بالسعادة \\
\hline .000 & $.477^{* *}$ & أشعر بالكسل \\
\hline .000 & $.409^{* *}$ & أنام جيداً \\
\hline .000 & $.476^{* *}$ & أجد صعوبة يِّ التركيز على دراستي \\
\hline .000 & $.489^{* *}$ & 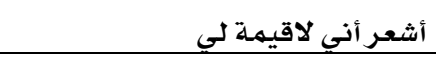 \\
\hline .000 & $.352^{* *}$ & أحلم أحلأما مزعجة \\
\hline .000 & $.480^{* *}$ & أنا حزينة \\
\hline .000 & $.447^{* *}$ & أنا واثقة من نفسي \\
\hline .000 & $.391^{* *}$ & أشعر بالتعب \\
\hline .000 & $.531^{* *}$ & تركيزي ضعيف \\
\hline .000 & $.495^{* *}$ & أقلق أثناء النوم \\
\hline .000 & $.326^{* *}$ & لي أصدقاء كثيرون \\
\hline .000 & $.508^{* *}$ & أشعر بالضيق \\
\hline .000 & $.474^{* *}$ & أنا سرحأنة \\
\hline .000 & $.523^{* *}$ & أشعر بالوحدة _أنني وحيدة \\
\hline .000 & $.507^{* *}$ & أشعر أنني تعيسة \\
\hline .000 & $.430^{* *}$ & الحياة حلوة \\
\hline .000 & $.450^{* *}$ & أشعر أنني فاشلة \\
\hline .000 & $.463^{* *}$ & أشعر بالممل_أنا زهقأنة \\
\hline .000 & $.358^{* *}$ & أشعر بالغضب \\
\hline .000 & $.468^{* *}$ & أنا راضية عن حياتي \\
\hline .000 & $.447^{* *}$ & هناك أشياء كثيرة تضايقني \\
\hline .000 & $.497^{* *}$ & أنا متشائمة \\
\hline .000 & $.443^{* *}$ & ستحدث لي أشياء سيئة \\
\hline .000 & $.347^{* *}$ & كثير من الناس يحبوني \\
\hline .000 & $.498^{* *}$ & أكره نفسي \\
\hline .000 & $.490^{* *}$ & أمـا متفائلة_أتوقع الخير \\
\hline
\end{tabular}

•. . . علاقة ذات دلالة واضحة عند مستوى ا •.,

\section{r^q}


المجلى للخاهس .. العك الأول .. يناير .. الآم

جدول رقم (ه): يوضح النسب المئوية والمتوسط الحسابي والانحراف المعياري لاجابات عينة

الدراسة لمحور القلق الميابق

\begin{tabular}{|c|c|c|c|c|c|}
\hline الالانحراف & الحسوسبـط & كيديرا & أيحاثاث & ثادرا| & محور القلق \\
\hline .767 & 2.24 & 44.0 & 35.7 & 20.3 & 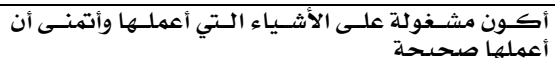 \\
\hline .797 & 2.16 & 40.8 & 34.1 & 25.1 & إذا مرض أحد بِ بيتنا أخاف عليه أن بيوت \\
\hline .766 & 2.13 & 36.9 & 39.7 & 23.4 & حركتى كثيرة \\
\hline .795 & 2.10 & 37.0 & 36.0 & 27.0 & أحترس من كل شيء \\
\hline .769 & 2.09 & 34.7 & 40.1 & 25.3 & اكون مرتاحة عندما لا لتحدأني أحد فِ عمل شيء \\
\hline .784 & 2.07 & 34.4 & 38.2 & 27.4 & لا أطيق سماع الأصوات الشديدة \\
\hline .733 & 2.03 & 28.3 & 46.2 & 25.5 & أخاف أن أعمل أشياء ثم أندم عليها \\
\hline .806 & 2.01 & 32.9 & 35.2 & 31.9 & أخاف أن يحدث شيء خطر فِ البيت وأنا بعيدة عنه \\
\hline .753 & 2.00 & 28.2 & 43.5 & 28.4 & أخاف من أي شيء دحصل لي لي لي \\
\hline .761 & 1.99 & 28.4 & 42.2 & 29.4 & أرتبك وأضطرب إذا حدث شيء \\
\hline .767 & 1.96 & 27.5 & 41.1 & 31.4 & تجيني أفكار كثيرة مـع بعضها \\
\hline .753 & 1.95 & 26.0 & 43.2 & 30.8 & أحس بأن قلبي يدق سسرعة \\
\hline .767 & 1.95 & 27.1 & 41.1 & 31.9 & أنسى أشيـاء كثيرة عندما أربـد عملها \\
\hline .756 & 1.94 & 25.6 & 42.6 & 31.8 & أحس بالتعب بسرعة عندما أقوم بعمل شيء \\
\hline .712 & 1.92 & 21.8 & 48.8 & 29.4 & ذهابي للمرحاض _الحمام_يكون \\
\hline .789 & 1.92 & 27.2 & 37.2 & 35.6 & أهرب من المشاكل التى تحدث لي \\
\hline .769 & 1.91 & 25.3 & 40.2 & 34.5 & أخاف أن يكون صديقاتي غر راضين عني \\
\hline .780 & 1.89 & 25.6 & 38.1 & 36.3 & أتكله سرعة \\
\hline .739 & 1.86 & 21.1 & 43.5 & 35.4 & 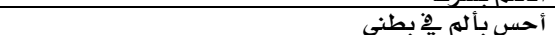 \\
\hline .802 & 1.85 & 25.7 & 33.6 & 40.7 & أصرخ ششدة \\
\hline .752 & 1.83 & 21.2 & 40.8 & 38.0 & أرتيك إذا رأني أحد وأنا أقوم بعمل شيء \\
\hline .728 & 1.82 & 19.2 & 44.0 & 36.8 & تأتينى أفكار تضايقنى \\
\hline .782 & 1.82 & 23.2 & 35.8 & 41.0 & أحس أننى مشغولة ششىء لا أعرفه \\
\hline .750 & 1.82 & 20.6 & 40.6 & 38.8 & أحس بألم فِ \\
\hline .788 & 1.81 & 23.3 & 34.5 & 42.2 & أرى أحلأما مختفة وأنا نائه \\
\hline .779 & 1.76 & 21.1 & 33.7 & 45.1 & أشعر أنني أربـد أن أحك جلدي \\
\hline .815 & 1.76 & 24.0 & 27.9 & 48.1 & بدى تعرق وتصير باردة \\
\hline .743 & 1.74 & 18.0 & 38.3 & 43.6 & أحس بجفاف وحرقة فِّ حلقى \\
\hline .778 & 1.74 & 20.6 & 32.9 & 46.5 & أحس أن كلامي مضظرب والنّاس لايفهمونه \\
\hline .792 & 1.72 & 21.3 & 29.9 & 48.9 & أحس أن عقلى لايفكر شكل مضبوط \\
\hline .736 & 1.72 & 17.0 & 38.2 & 44.8 & أحس يأنني مريضة \\
\hline .745 & 1.72 & 17.7 & 36.8 & 45.6 & 2ِ إ أكثر الآوقات أكون نائمة \\
\hline .788 & 1.72 & 20.8 & 30.1 & 49.1 & بدى ترتحف عندما أكتـ أمام الناس \\
\hline .777 & 1.72 & 20.0 & 31.7 & 48.4 & لا أستطيع أن أركز يِّ أي شىء أعمله \\
\hline .792 & 1.71 & 20.9 & 28.8 & 50.3 & لا أستطيح أن أتنفس براحة \\
\hline .734 & 1.68 & 15.9 & 35.8 & 48.3 & أتنهد بشدة \\
\hline .767 & 1.67 & 18.3 & 30.5 & 51.2 & أعضاء جسمى تهتزوترتعش \\
\hline .797 & 1.66 & 20.5 & 25.2 & 54.4 & أقوم بأعمال تضحك الناس على \\
\hline .772 & 1.65 & 18.3 & 28.0 & 53.8 & أحس أن الأشياء حولى مضطرية \\
\hline .738 & 1.63 & 15.5 & 32.1 & 52.4 & بحدث معي الإمساك \\
\hline .780 & 1.63 & 18.7 & 25.4 & 56.0 & لا أستطيع أن أبلـع الأكل عندما آكل \\
\hline .746 & 1.62 & 16.0 & 30.2 & 53.8 & أصاب بالإسهال \\
\hline .728 & 1.54 & 14.0 & 26.4 & 59.6 & ألاحظ أن لوني يتغير \\
\hline .757 & 1.51 & 16.1 & 18.4 & 65.6 & أحس أن عيوني تنتفخ وتصبر كبيرة \\
\hline .727 & 1.45 & 14.0 & 17.5 & 68.5 & تصيبني الاغفماء \\
\hline
\end{tabular}

حساب الِصدل معام والثبات :

7 أولاً : معامل الضدات والثبات ؛ (معامل الفا كرونباخ)

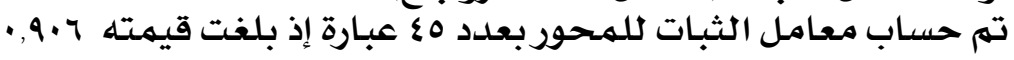

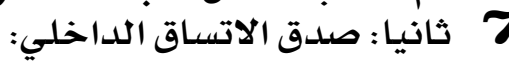

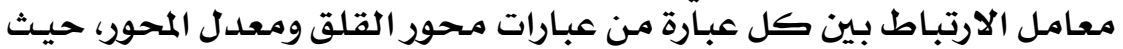

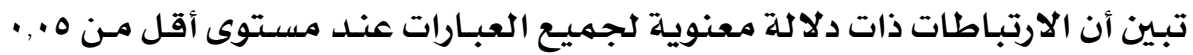




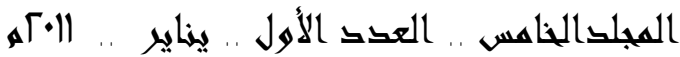

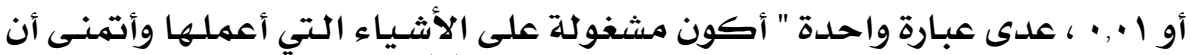

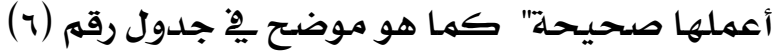

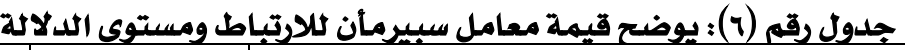

\begin{tabular}{|c|c|c|}
\hline مسنوى الدلالة & معامل سبيرمان & محور القلق \\
\hline .000 & .481 & أحس بأن قلبى يدق بسرعة \\
\hline .000 & 294 & أخاف أن أعمل أشياء ثم أندم عليها \\
\hline .000 & .469 & أري أحلأمسا مخيفة وأنا نائمى \\
\hline .000 & .457 & لا أستطيـع أن أركز فِّ أي شيء أعمله \\
\hline .000 & .503 & لا أستطيع أن أتنفس براحة \\
\hline .168 & .062 & أكون مشغولة على الأشياء التى أعملها وأتمنى أن أعملها صحيحة \\
\hline .000 & .360 & أخاف أن يكون صديقاتى غير راضين عنى \\
\hline .000 & .486 & أحس أن عقلى لايفكر بشكل مضبوط \\
\hline .000 & .441 & يلدى تعرق وتصير بـاردة \\
\hline .000 & .455 & أخاف من أي شيء يحصل لي \\
\hline .000 & $.377^{\prime}$ & أنسي أشياء كثيرة عندمـا أريد عملها \\
\hline .000 & .436 & أهرب من المشـاكل التى تحدث لى \\
\hline .000 & .353 & تجيني أفكار كثيرة مـع بعضها \\
\hline .000 & .583 & لا أستطيـع أن أبلـع الأكل عندمـا آكل \\
\hline .000 & .402 & أرتبك وأضطرب إذا حدث شىء \\
\hline .000 & .310 & أخاف أن يحدث شيء خطر فِ البيت وأنا بعيدة عنه \\
\hline .000 & .480 & أحس أنني مشغولة بشيء لا أعرفه \\
\hline .000 & .535 & أحس بألى قِ بطنى \\
\hline .000 & .481 & أرتبك إذا رأنى أحد وأنا أقوم بعمل شى؟ \\
\hline .000 & .509 & تأتينى أفكار تضايقنى \\
\hline .000 & .481 & أحس بـألم بِ رأسـى \\
\hline .000 & .264 & لا أطيق سماع الأصوات الشديدة \\
\hline .000 & .580 & أحس أن الأشياء حولى مضطربة \\
\hline .000 & .536 & أقوم بأعمال تضحك الناس على \\
\hline .000 & .263 & اكون مرتاحة عندمـا لايتحدأنى أحد ِِّ عمل شيء \\
\hline .000 & .536 & أصاب بالإسهال \\
\hline .021 & .104 & أحترس من كل شيء \\
\hline .000 & .453 & أحس بالتعب بسرعة عندما أقوم بعهل شيء \\
\hline .000 & .212 & حركتي كثيرة \\
\hline .000 & .432 & أتكله بسرعة \\
\hline .000 & .244 & إذا مرض أحدل يِّ بيتنا أخاف عليه أن يهوت \\
\hline .000 & .477 & أصرخ ششدة \\
\hline .000 & .598 & أعضاء جسمي تهتزوترتعش \\
\hline .000 & .550 & أتنهد بشدة \\
\hline .000 & .548 & أحس بأنني مريضة \\
\hline .000 & $.580^{*}$ & أحس أن كلامي مضظرب والناس لايفهمونه \\
\hline .000 & .552 & أحس بجفاف وحرقة ِِ حلقيى \\
\hline .000 & .570 & أحس أن عيوني تنتفخ وتصير كبيرة \\
\hline .000 & .537 & ألاحظ أن لوني يتغير \\
\hline .000 & .482 & أشعر أننى أريد أن أحك جلدى \\
\hline .000 & .584 & يحلدث معى الإمساك \\
\hline .000 & .612 & تصيبني الإغماء \\
\hline .000 & .467 & 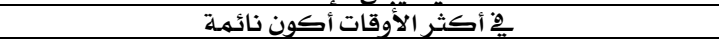 \\
\hline .000 & .529 & يلدى ترتجف عندما أكتب أمام الناس \\
\hline .000 & .298 & ذذهابي للمرحاض _الحمام_ يكون \\
\hline
\end{tabular}




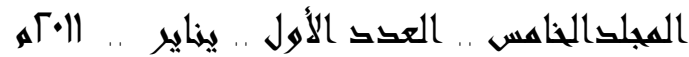

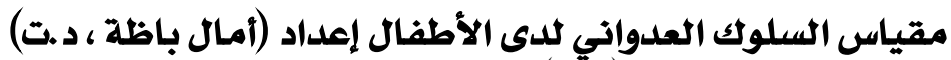

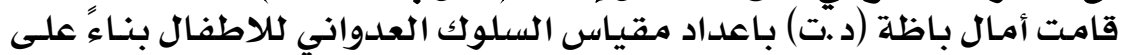

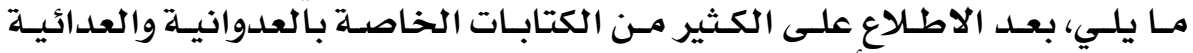

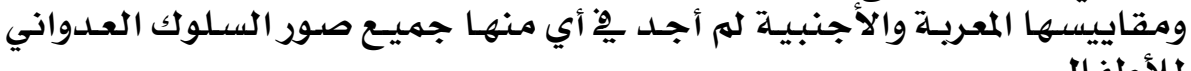
كلأطفال.

\section{م الدراسة الحالية: \\ 7}

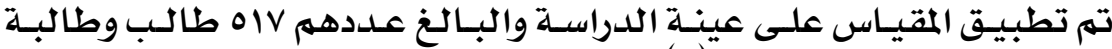

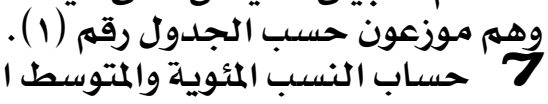

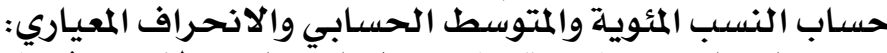

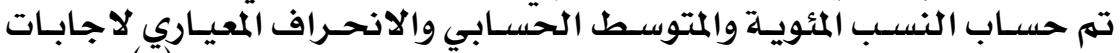

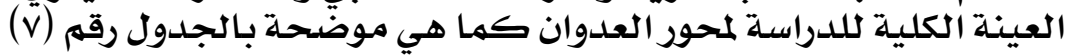

$$
\begin{aligned}
& \text { حسباب الِّلداق والثبات: } \\
& 7 \text { أولا : معامل المدات والثبات (معامل الفا كرونباخ) }
\end{aligned}
$$

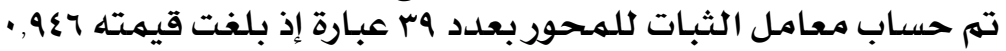
7

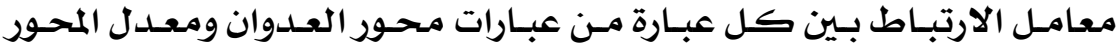

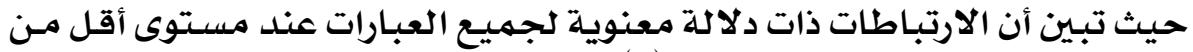

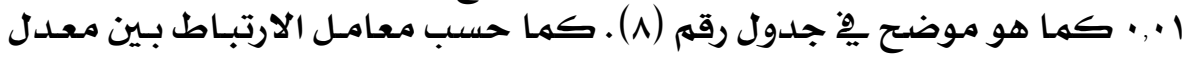

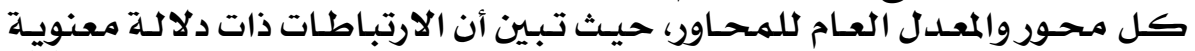

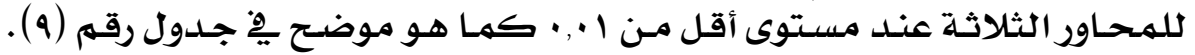

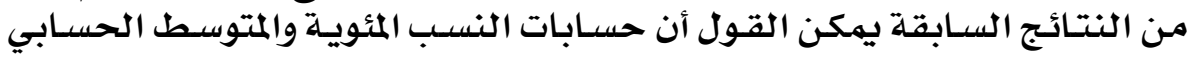

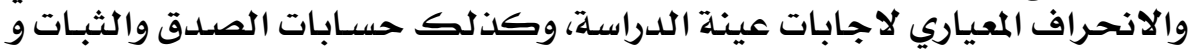

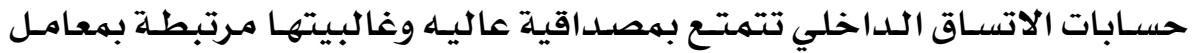

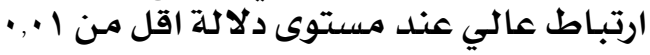

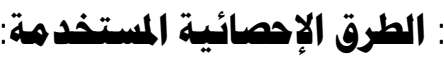

$$
\begin{aligned}
& 7 \\
& 7 \text { اختبار (ت). } \\
& 7 \\
& 7
\end{aligned}
$$

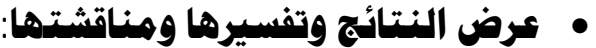

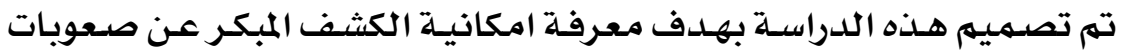

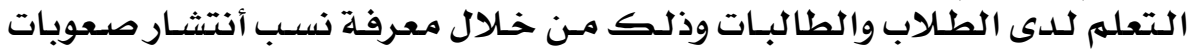

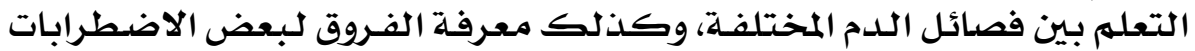

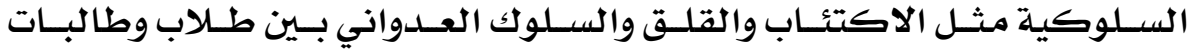




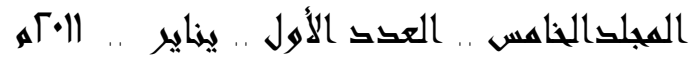

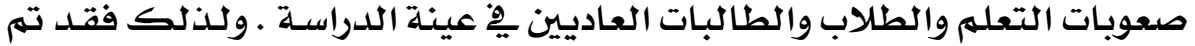

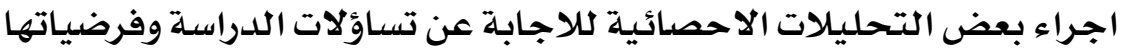

\section{جدول رقم (V) : يوضح النسب المئوية والمتوسط الحسابي والانحراف المعياري لاجابات الاتيات عينة الدراسة لمحور العدوان الميان}

\begin{tabular}{|c|c|c|c|c|c|}
\hline الانحياري & الحسوسط & يحثيراً & آحياثاث: & نيادراً & محور العدوان \\
\hline .901 & 2.17 & 50.2 & 16.3 & 33.5 & أحب قراءة قصص المغامرات البوليسية \\
\hline .856 & 1.89 & 31.6 & 25.7 & 42.7 & لا أتقبل الهزيمة فِ أنى لعبة بسهولة \\
\hline .824 & 1.85 & 27.6 & 30.0 & 42.4 & أغضب بسرعة إذا ضايقنى أي فرد \\
\hline .886 & 1.83 & 32.0 & 18.7 & 49.4 & أفضل أفلام العنف على غيرها من الأفلام \\
\hline .815 & 1.64 & 21.6 & 20.7 & 57.7 & أشعر بـالسعادة عند رؤيلة المقاتلة بين الحيوأنات \\
\hline .697 & 1.63 & 12.6 & 37.7 & 49.8 & أتشاجر مـع زميلاتى بافصل أو المدرسة \\
\hline .795 & 1.59 & 19.5 & 20.3 & 60.2 & أحصل على حقوقي بـالقوة \\
\hline .753 & 1.59 & 16.2 & 26.9 & 56.9 & أتضايق من عادات المحيطين بى \\
\hline .762 & 1.59 & 16.8 & 25.1 & 58.1 & أوجه اللوم والنقد النفسي على كل تصرفاتي \\
\hline .734 & 1.56 & 14.6 & 27.3 & 58.1 & لا أثق بالمحيطين بى \\
\hline .695 & 1.48 & 11.6 & 24.5 & 63.8 & أرد الإساءة البدنية بأقوى منها \\
\hline .692 & 1.45 & 11.5 & 21.8 & 66.7 & من السهل على أن أخيف زميلاتي \\
\hline .678 & 1.41 & 10.9 & 18.8 & 70.3 & أشعر بالسعادة عند رؤية مشاجرة بالضرب بين شخصـين \\
\hline .649 & 1.41 & 9.0 & 22.5 & 68.5 & لا أعتذر لزميلاتي ع ندما أسيء لفظيا إليهم \\
\hline .678 & 1.39 & 11.0 & 16.9 & 72.1 & أصرخ لأسباب تافهة \\
\hline .656 & 1.39 & 9.6 & 19.3 & 71.1 & أرد الإسـاءة اللفضية باساء بلدنية \\
\hline .675 & 1.38 & 10.9 & 16.7 & 72.4 & ملاكضمتهِ أوقات الفراغ بالمدرسة استخدام يدي مـع زميلاتي أو \\
\hline .642 & 1.38 & 8.8 & 20.8 & 70.4 & أفضل المشاجرة بـالبد مـع زميلاتي الأقل قوة منى \\
\hline .613 & 1.38 & 7.0 & 24.0 & 69.1 & أندفع لضرب زميلاتي بـاليد أو الرجل أو أى شيء آخر \\
\hline .630 & 1.36 & 8.2 & 19.8 & 72.0 & أقول بعض النكات والفكاهة بقصد السخرية \\
\hline .648 & 1.36 & 9.4 & 17.0 & 73.6 & أميل إلى تدبير خدع أو مكائد لـلآخرين \\
\hline .617 & 1.36 & 7.5 & 20.7 & 71.8 & إذا أساءت لى زميلة بلفظ غير مرغوب أرد بأكثر منه إساءة \\
\hline .636 & 1.35 & 8.9 & 17.1 & 74.1 & وأشعر بالعسادة إذا أخطأىت زميلتي ووجهت المعلمة لها النقد \\
\hline .614 & 1.33 & 7.8 & 16.9 & 75.3 & أحاول صرف أنتباه زميلاتى عن المعلمة \\
\hline 619 & 1.32 & 8.2 & 16.1 & 75.7 & أحاول إيقاع الضرر بالمحيطين بي دون أن يشعر بي أحد \\
\hline .590 & 1.32 & 6.5 & 19.2 & 74.4 & أضحك بصوت عالى بدون سبب بستحق ذلك \\
\hline .597 & 1.32 & 7.0 & 17.8 & 75.3 & أيل إلى السخرية من آراء الآخرين \\
\hline .589 & 1.32 & 6.5 & 18.6 & 74.9 & أميل كثيرأ لعمل عكس ما يطلب مني \\
\hline .581 & 1.30 & 6.3 & 18.0 & 75.8 & أصيح برفع صوتى على زميلاتى بالفصل بدون سبب واضح \\
\hline .570 & 1.30 & 5.6 & 19.2 & 75.2 & أحاول وخز أو إيذاء زميلاتى بدون أن يوجهوا لى إساءة \\
\hline .561 & 1.30 & 5.2 & 19.6 & 75.2 & أرغب ٍِِ العبث أو اللعب بمحتويات الفصل \\
\hline .568 & 1.27 & 6.2 & 14.6 & 79.2 & أميل إلى تحقير اللفظى والسخريـة من زميلاتي \\
\hline .550 & 1.26 & 5.4 & 15.7 & 79.0 & أحاول تدمير ممتكات غيرى مـن الأطفال \\
\hline .554 & 1.26 & 5.7 & 14.6 & 79.7 & أحب تمزيق بعض الأشياء حتى ولو كانت مهمة \\
\hline .550 & 1.26 & 5.5 & 15.0 & 79.5 & أندفع لتدمير محتويات الفصل رغم تعرضي للعقاب المدرسي \\
\hline .542 & 1.25 & 5.3 & 14.2 & 80.5 & أدفع زميلاتي إلى مضايقة المشرفات أو المدرسـات لفظياً \\
\hline .536 & 1.23 & 5.5 & 12.0 & 82.5 & أصرخ بقوة هِّ الفصل للفت أنظار الآخرين إلى بجون سبب \\
\hline .517 & 1.23 & 4.6 & 13.4 & 82.0 & أستخدم ألفاظا وعبارات غير محبوبة ِِ التعامل مـع زميلاتي \\
\hline .520 & 1.22 & 4.9 & 12.3 & 82.8 & أفكر يِّ إيقاع الضرر بيعض المشرفات أو المدرسات \\
\hline
\end{tabular}




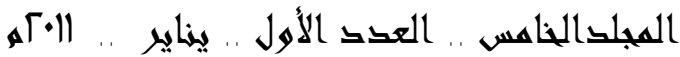

جدول رقم (^): يوضح قيمة معامل سبيرمان للارتباط ومستوى الدلالة

\begin{tabular}{|c|c|c|}
\hline مسنول الدلادة & معامل سبيرمان للارتباط & 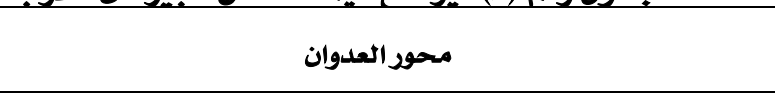 \\
\hline .000 & $.464^{* *}$ & أتشاجر مـ زميلاتى بافصل أو المدرسسة \\
\hline .000 & $.613^{* *}$ & أندفع لضرب زميلاتى باليد أو الرجل أو أي شىء آخر \\
\hline .000 & $.543^{* *}$ & أحاول تدمير ممتكات غيري من الأطفال \\
\hline .000 & $.584^{* *}$ & أرغب يِّ العبث أو اللعب بهحتويات الفصل \\
\hline .000 & $.642^{* *}$ & أحب تمزيق بعض الأشياء حتى ولو كانت مهمة \\
\hline .000 & $619^{* *}$ & أحاول وخز أو إيذاء زميلاتى بدون أن يوجهوا لى إساءة \\
\hline .000 & $.595^{* *}$ & أفضل يف أوقات الفراغ بالمدرسة استخدام يدي مـع زميلاتى أو ملاكمتهن \\
\hline .000 & $.657^{* *}$ & 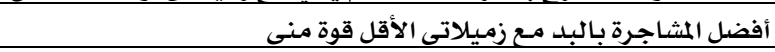 \\
\hline .000 & $.627^{* *}$ & أندفع لتدمير محتويات الفصل رغم تعرضى للعقاب المدرسى \\
\hline .000 & $.538^{* *}$ & أحصل على حقوقى بالقوة \\
\hline .000 & $.558^{* *}$ & أرد الإسـاءة البدنية بأقوى منها \\
\hline .000 & $.586^{* *}$ & أرد الإسـاءة اللفضية بإساء بدنية \\
\hline .000 & $.631^{* *}$ & أفكر يِّ إيقاع الضرر بيعض المشرفات أو المدرسات \\
\hline .000 & $.558^{* *}$ & أصرخ لأسباب تافهة \\
\hline .000 & $.663^{* *}$ & أصيح برفع صوتى على زميلاتى بالفصل بدون سبب واضح \\
\hline .000 & $.639^{* *}$ & أميل إلى تدبير خدع أو مكائد للآخرين \\
\hline .000 & $.641^{* *}$ & أستخدم ألفاضاً وعبارات غير محبوبة ٍِِ التعامل مـع زميلاتى \\
\hline .000 & $.618^{* *}$ & أضحك بصوت عالى بدون سبب يستحق ذلك \\
\hline .000 & $.605^{* *}$ & أصرخ بقوة ِِِ الفصل للفت أنظار الآخرين إلى بجون سبب \\
\hline .000 & $.501^{* *}$ & لا أعتذر لزميلاتى ع ندما أسىء لفظياً إليهم \\
\hline .000 & $.612^{* *}$ & أدفع زميلاتى إلى مضايقة المشرفات أو المدرسـات لفظياً \\
\hline .000 & $.645^{* *}$ & إذا أساءت لى زميلة بلفظ غير مرغوب أرد بأكثر منه إساءة \\
\hline .000 & $.655^{* *}$ & أميل إلى تحقير اللفظى والسخرية من زميلاتى \\
\hline .000 & $.643^{* *}$ & أقول بعض النكات والفكاهة بقصد السخرية \\
\hline .000 & $.628^{* * *}$ & أيل إلى السخرية من آراء الآخرين \\
\hline .000 & $.422^{* *}$ & لا أتقبل الهزيمة يِّ أي لعبة بسهولة \\
\hline .000 & $.668^{* *}$ & أحاول إيقاع الضرر بالمحيطين بى دون أن يشعر بى أحد \\
\hline .000 & $.621^{* * *}$ & أشعر بالسعادة عند رؤية مشاجرة بالضرب بـين شخصين \\
\hline .000 & $.495^{* * *}$ & 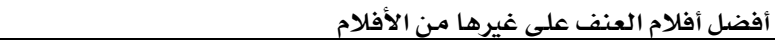 \\
\hline .000 & $.509^{* * *}$ & أشعر بالسعادة عند رؤية المقاتلة بين الحيوأنات \\
\hline .000 & $.388^{* * *}$ & أغضب بسرعة إذا ضايقنى أي فرد \\
\hline .000 & $.539^{* *}$ & لا أثق بالمحيطين بى \\
\hline .000 & $.672^{* *}$ & أحاول صرف أنتباه زميلاتى عن المعلمة \\
\hline .000 & .416 & أوجه اللوموالنقد النفسى على كل تصرفاتى \\
\hline .000 & $.554^{* *}$ & أشعر بالعسبادة إذا أخطأحت زميلتى ووجهت المعلمة لها النقد واللوم \\
\hline .000 & $.581^{* * * 3}$ & أميل كثيراً لعمل عكس مـا يطلب منى \\
\hline .000 & $.577^{* *}$ & من السهل على أن أخيف زميلاتى \\
\hline .000 & $.225^{* * *}$ & أحب قراءة قصص المغامرات البوليسية \\
\hline .000 & $.454^{* *}$ & أتضـايق من عادات المحيطين بى \\
\hline
\end{tabular}




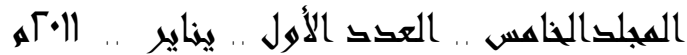

جدول رقم (9): يوضح قيمة معامل سبيرمان كلارتباط ومستوى الدلالة

\begin{tabular}{|c|c|c|}
\hline مسنوى الدلالة & معامل سبيرمان للارتباط & المحود \\
\hline .000 & $.672^{* *}$ & محور الاكتئاتب \\
\hline .000 & $.838^{* *}$ & محور القلق \\
\hline .000 & $.850^{* *}$ & محور العدوان \\
\hline
\end{tabular}

• • . علاقة ذات دلالة واضحة عند مستوى ا +., .

لأو أو : عرض النتائج وتفسيرها:

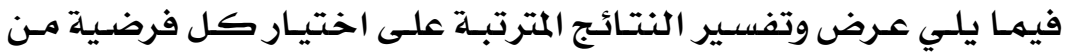
فرضيات الدراسة.

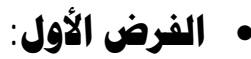

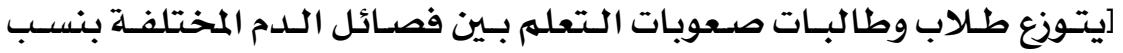
متسـاوية ولا يوجد تاثير للجنس على التس التوزيع].

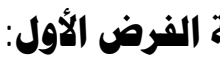

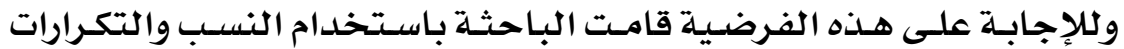

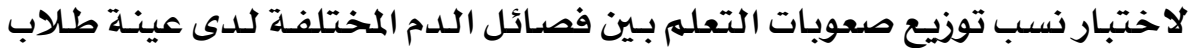

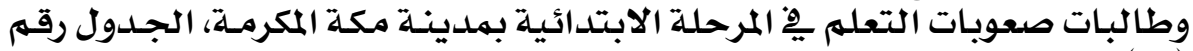

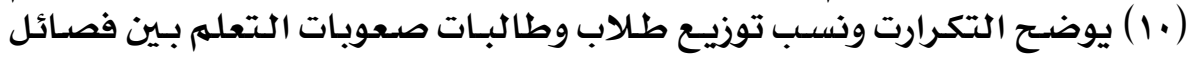

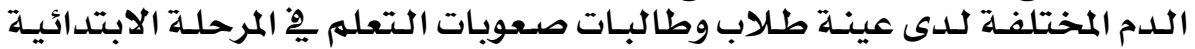
بمدينة مكة المكرمهة.

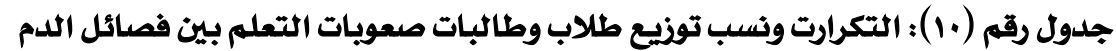

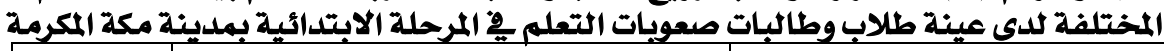

\begin{tabular}{|c|c|c|c|c|c|c|c|}
\hline \multirow[t]{2}{*}{ المجموع } & \multicolumn{4}{|c|}{ فصـائل الــدم } & \multirow{2}{*}{\multicolumn{3}{|c|}{ طلاب وطالبات صعوبات التعلم }} \\
\hline & $\mathrm{O}$ & $\mathrm{B}$ & $\mathrm{AB}$ & A & & & \\
\hline Vq & ir & $0 \wedge$ & 1 & $\varepsilon$ & التكرار & \multirow[t]{2}{*}{ ذ ذكور } & \multirow{2}{*}{$\overline{7}$} \\
\hline$\% 1 \ldots$ & IV,I & $v_{\imath}, r$ & $1, r$ & $0, r$ & النسببة ٪ & & \\
\hline 19 & 1. & 0 & . & $\varepsilon$ & التكرار & أناث & 3 \\
\hline$\% 1 \ldots$ & $\Delta Y, T$ & $r q, r$ & . & $Y 1,1$ & النسبة ٪ & & \\
\hline
\end{tabular}

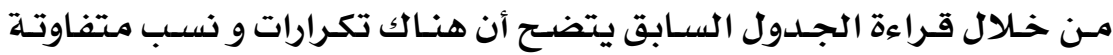

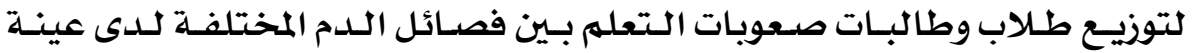

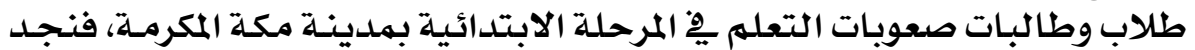

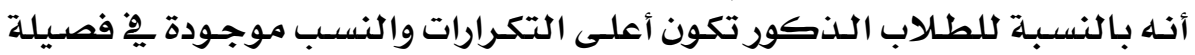

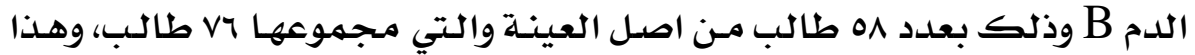

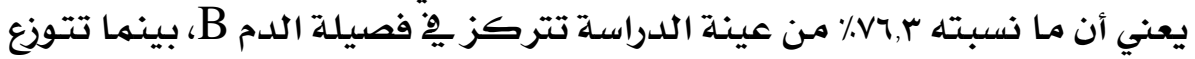

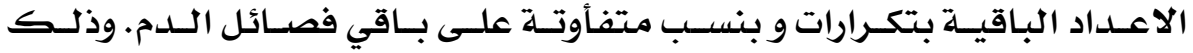

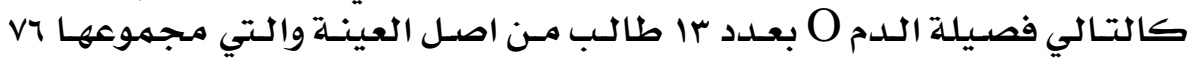

\section{Yq०}


المجلى للخاهس .. العك الأول .. يناير .. الآم

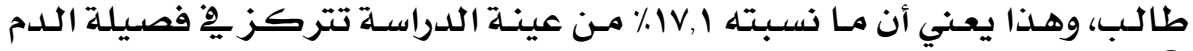

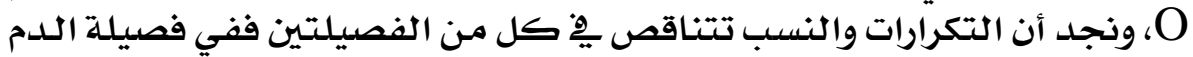

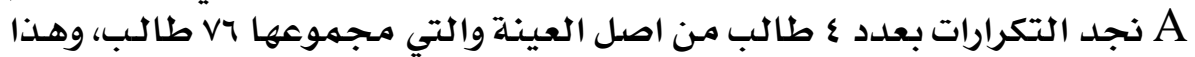

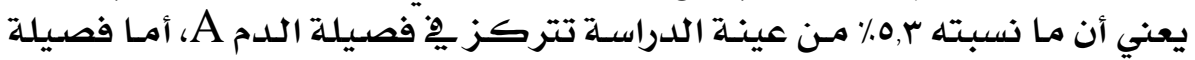

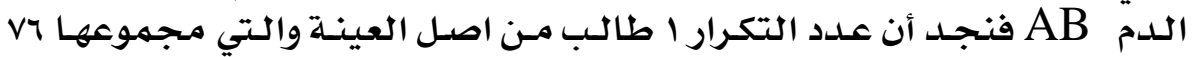

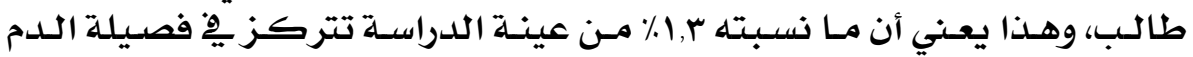

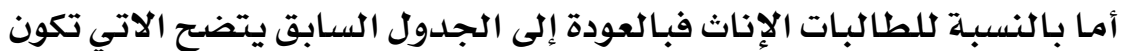

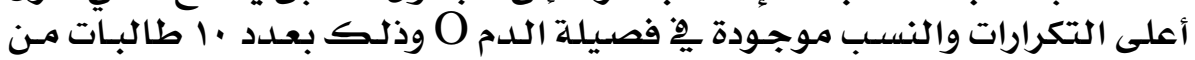

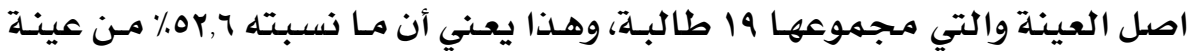

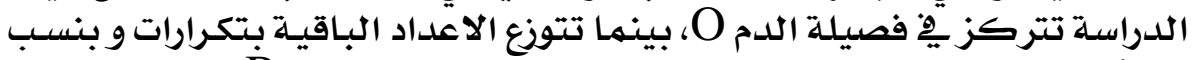

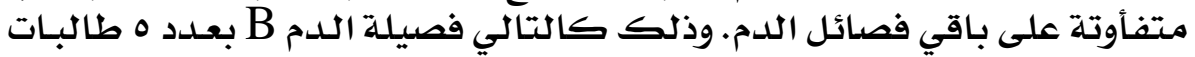

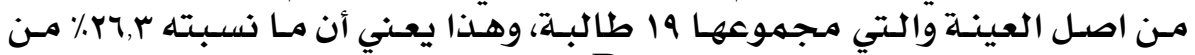

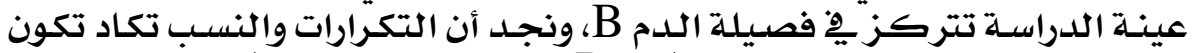

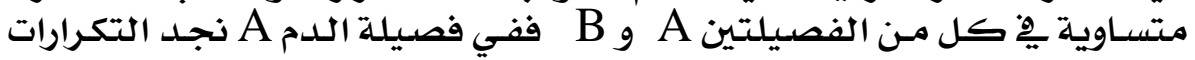

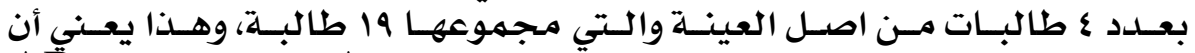

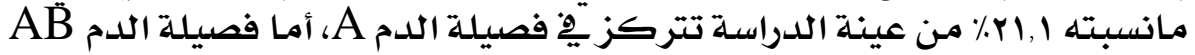

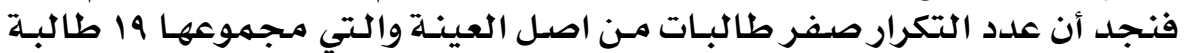

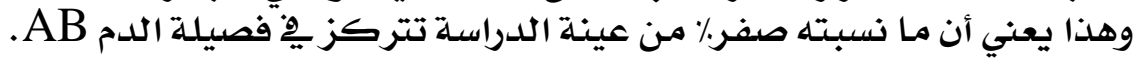

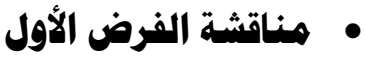

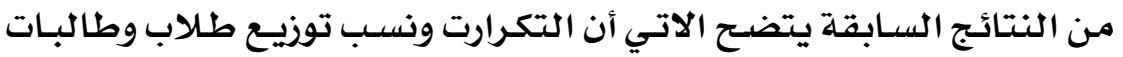

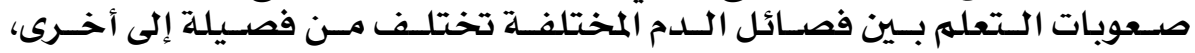

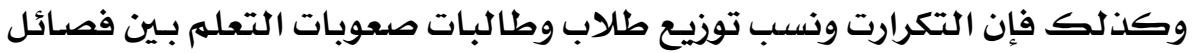

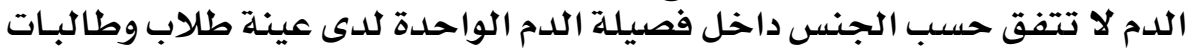

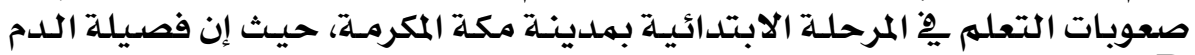

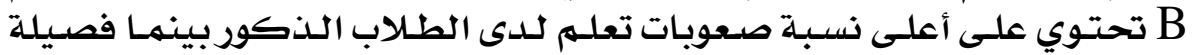

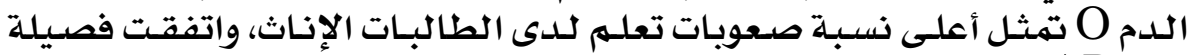

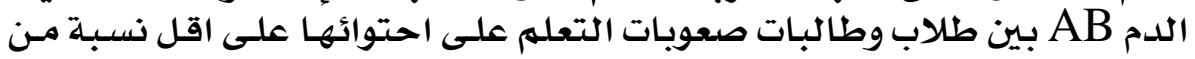
توزيع طلاب وطالبات صعوبات التعلهم.

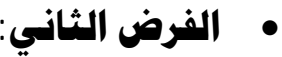

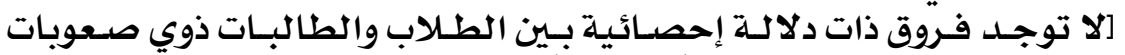

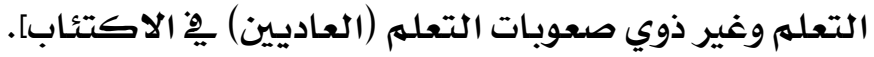

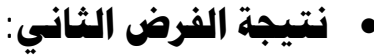

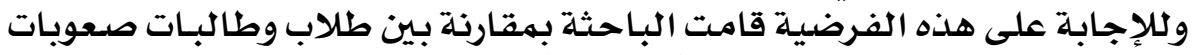

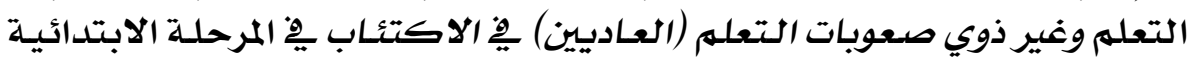


المجلى الخاهس .. العقد الأول .. يناير .. المه

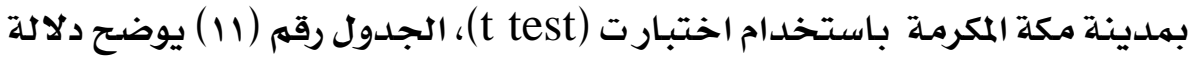

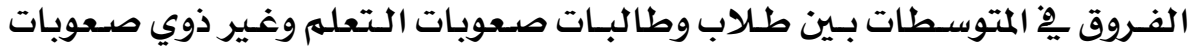

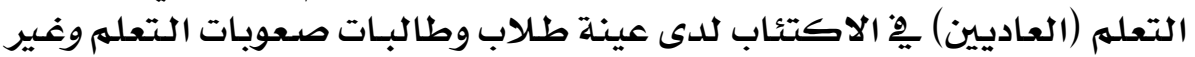

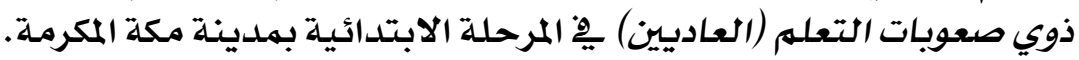

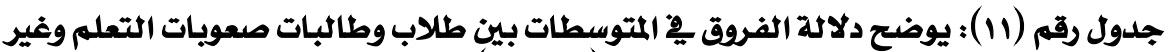

\begin{tabular}{|c|c|c|c|c|c|c|}
\hline 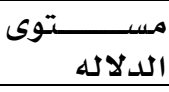 & درجـــــات & $\mathrm{T}$ & الالانحيـــراف & المتوسط & $\mathrm{N}$ & العـينة \\
\hline \multirow{2}{*}{ د } & \multirow{2}{*}{ raq } & \multirow{2}{*}{$1,1 \cdot 0$} & $\cdot r \leqslant \leqslant$ & 1,09 & V7 & طلاب صعوبات \\
\hline & & & $\cdot, \Upsilon \wedge \varepsilon$ & $1,0 Y$ & Y97 & طلاب عاديين \\
\hline \multirow{2}{*}{ 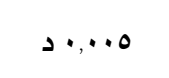 } & \multirow{2}{*}{$1 \varepsilon r$} & \multirow{2}{*}{$r, 10$} & • & 1,01 & 19 & طالبات صعوبات \\
\hline & & & $\cdot, \mathrm{Y \Lambda}$ & I, rی & TY & طالبات عاديـين \\
\hline
\end{tabular}

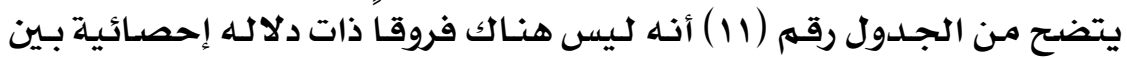

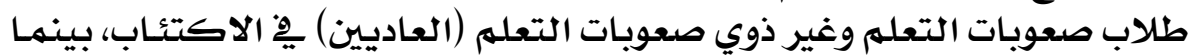

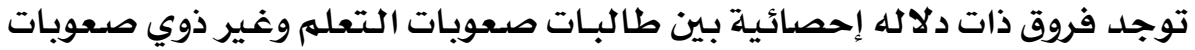

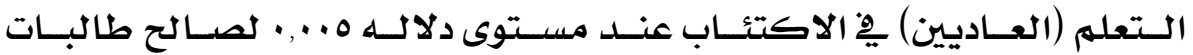

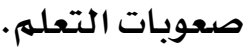

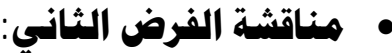

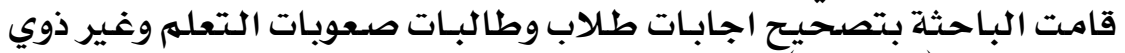

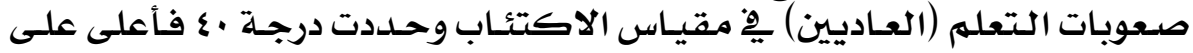

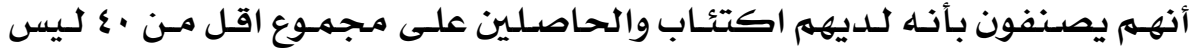

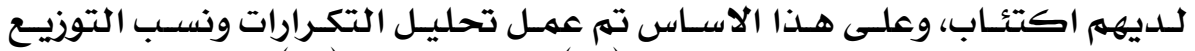

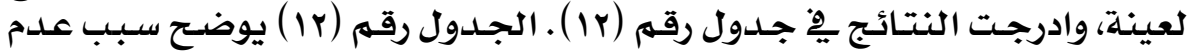

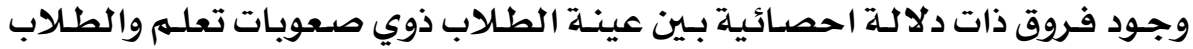

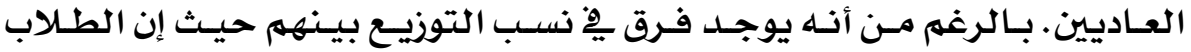

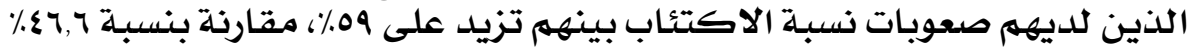

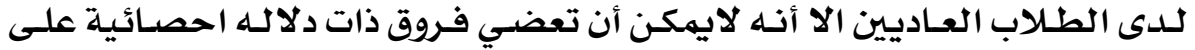

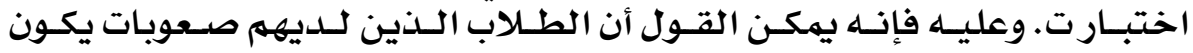

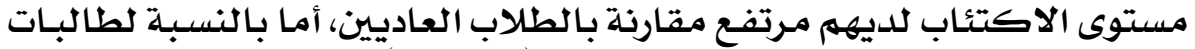

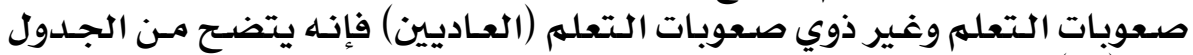

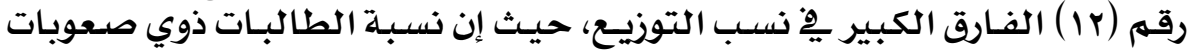

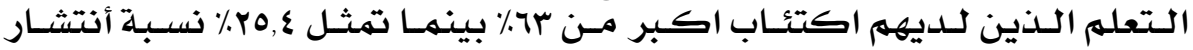

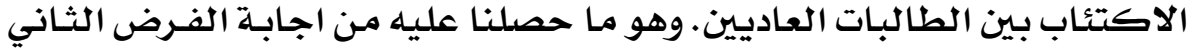

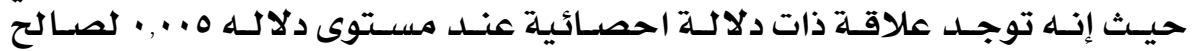

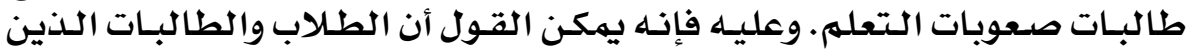

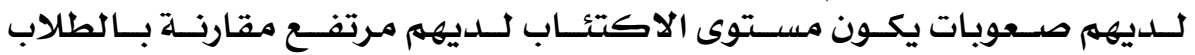




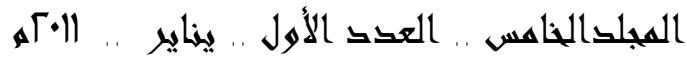

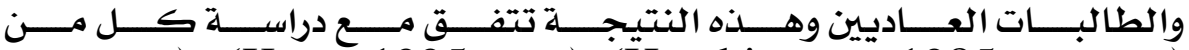

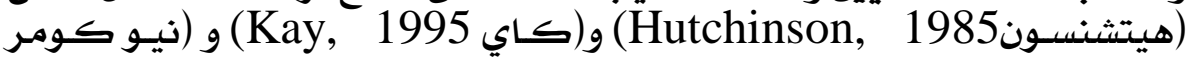

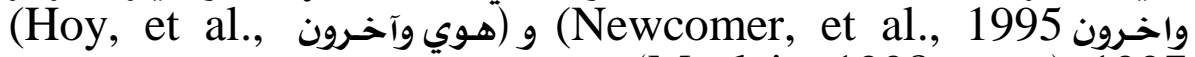

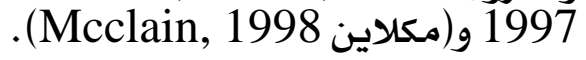

جدول رقم (r) ) يوضح التكرارت ونسب توزيع طلاب وطالبات صعويات التعلم وغير ذوي

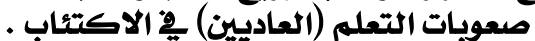

\begin{tabular}{|c|c|c|c|c|}
\hline \multirow{2}{*}{ الشــــرح } & \multicolumn{2}{|c|}{ لديهم اكتئاب } & \multicolumn{2}{|c|}{ توصيف العينة } \\
\hline & عاديين & ذوى صعوبات & & \\
\hline \multirow{2}{*}{ 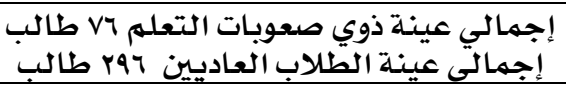 } & $1 \% \Lambda$ & so & التكرار & \multirow{2}{*}{ ذكر } \\
\hline & $\%\{€ 7,7$ & $\% .09, Y$ & النسبية & \\
\hline \multirow{2}{*}{ 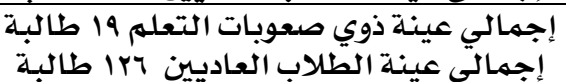 } & $r r$ & Ir & التكرار & \multirow[t]{2}{*}{ أنثى } \\
\hline & $\%$ \% $0, \xi$ & $\% \pi r, 1$ & النسبـة & \\
\hline
\end{tabular}

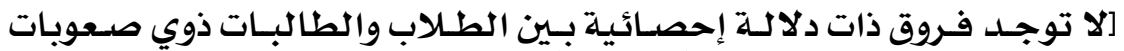

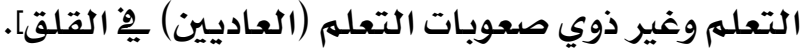

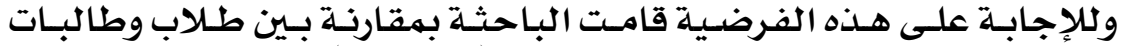

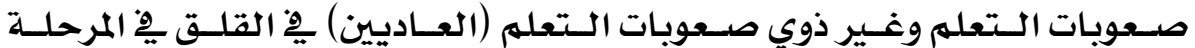

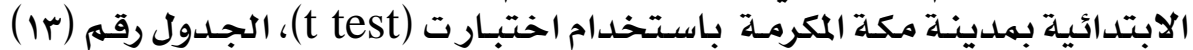

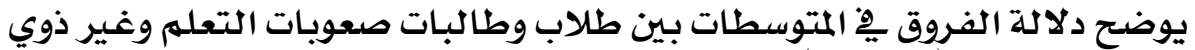

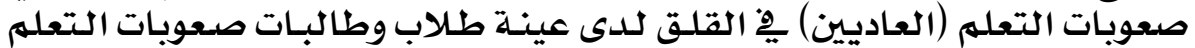

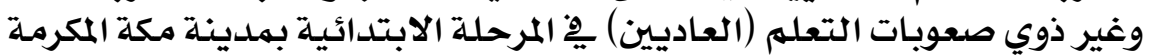

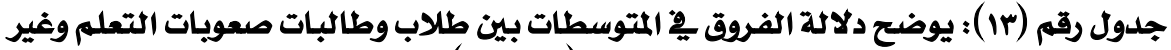

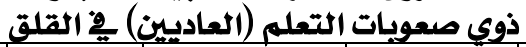

\begin{tabular}{|c|c|c|c|c|c|c|}
\hline مسلدلــتوى & درجريــــــات & $\mathrm{T}$ & الالانحيــــــراف & المتتوسط & $\mathrm{N}$ & العـينـة \\
\hline \multirow{2}{*}{ } & \multirow{2}{*}{ raq } & \multirow{2}{*}{$1,1.9$} & $\cdot$, ror & $1,9$. & VT & طلاب صعوبات \\
\hline & & & . rol & 1,10 & raT & طلاب عاديـين \\
\hline \multirow{2}{*}{ } & \multirow{2}{*}{$1 \leqslant r$} & \multirow{2}{*}{ •, Vo } & • & $1, \Lambda r$ & 19 & طالبـات صعوبـات \\
\hline & & & •, rr & $1, V V$ & IrT & طالبـات عاديـين \\
\hline
\end{tabular}

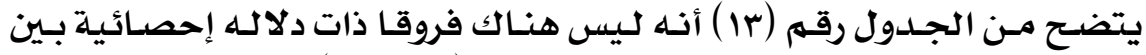

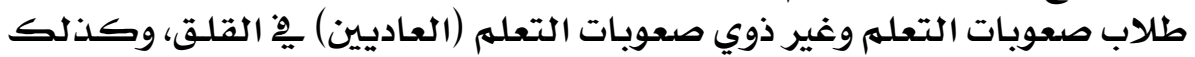

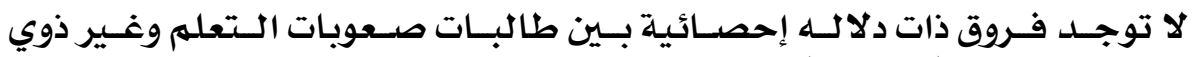

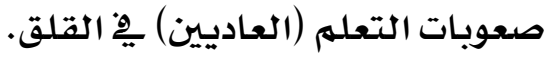

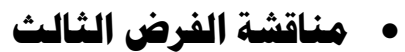

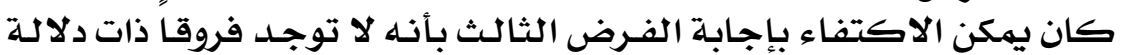

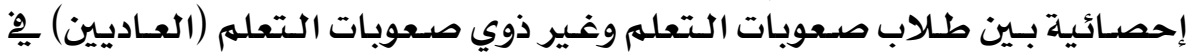

\section{rq^}




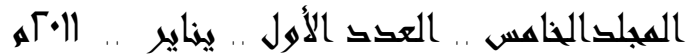

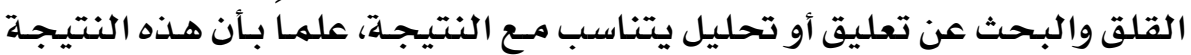

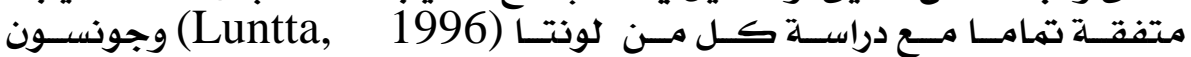

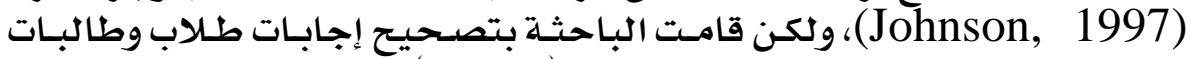

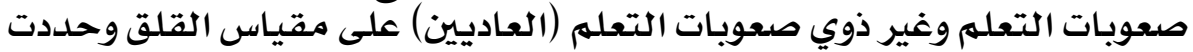

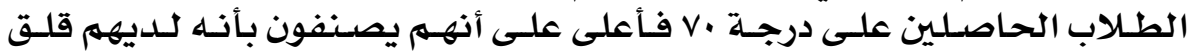

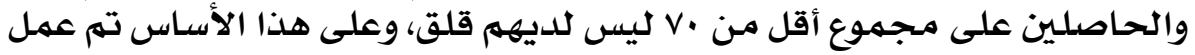

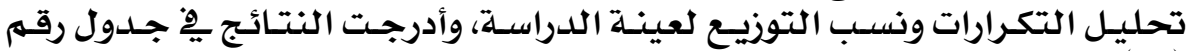

جلدول رقم (ع 1): يوضح التكرارت وذسب توزيع طلاب وطالبات صعوبات التعلم وغير ذوي

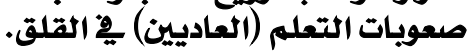

\begin{tabular}{|c|c|c|c|c|}
\hline \multirow{2}{*}{ الشـــــرح } & \multicolumn{2}{|c|}{ لديهـم قلق } & \multicolumn{2}{|c|}{ توصيف العينة } \\
\hline & عاديـين & ذوي صعوبات & & \\
\hline \multirow{2}{*}{ 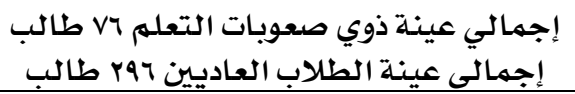 } & rYE & 7. & التكرار & \multirow[t]{2}{*}{ ذكر } \\
\hline & $\% \vee v, V$ & $\% \vee \wedge, 9$ & النسبية & \\
\hline \multirow{2}{*}{ 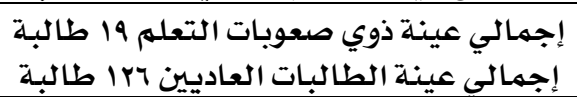 } & $\wedge T$ & 10 & التكرار & \multirow[t]{2}{*}{ أنثى } \\
\hline & $\%$ \% r, r & $\% \vee \wedge, 9$ & النسبية & \\
\hline
\end{tabular}

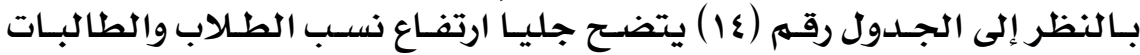

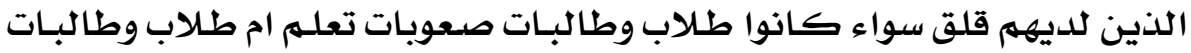

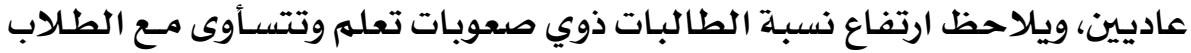

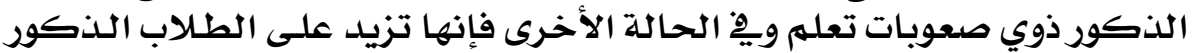

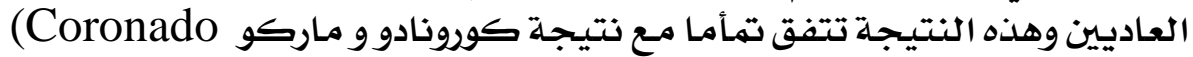

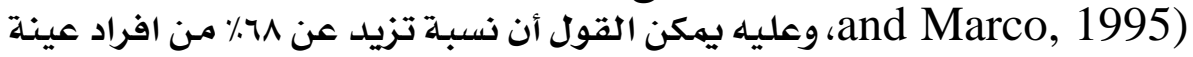

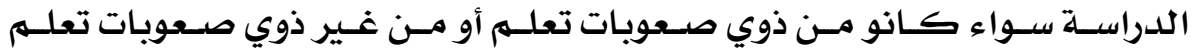

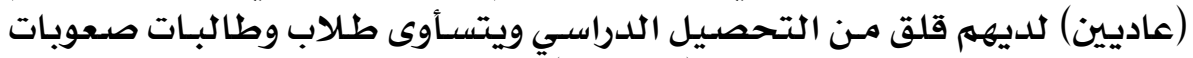

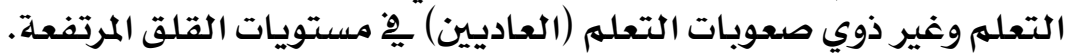

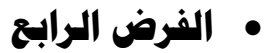

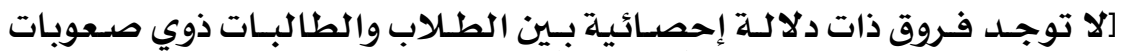

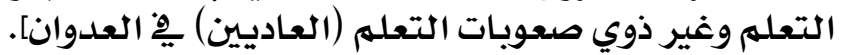

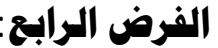

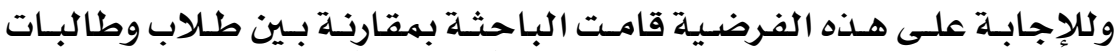

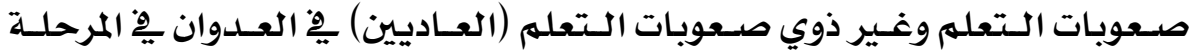

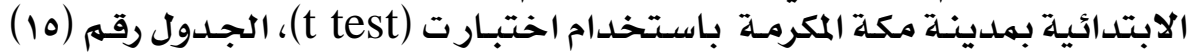

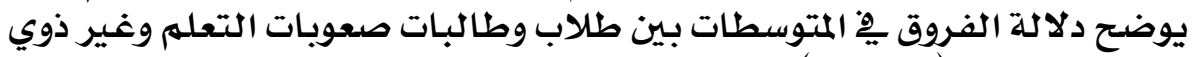

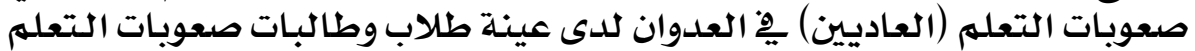

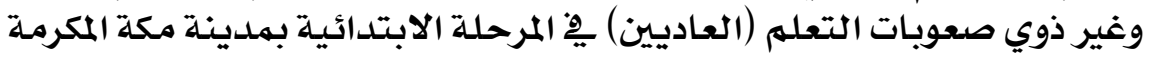

\section{Yq9}




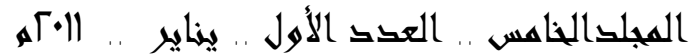

جدول رقم (10): يوضح دلالة الفروق يـ المتوسطات بين طلاب وطالبات صعوبات التعلم وغير

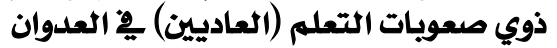

\begin{tabular}{|c|c|c|c|c|c|c|}
\hline 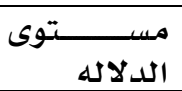 & درجيــــات & $\mathrm{T}$ & الالمعياري & المتوسط & $\mathrm{N}$ & العـينـة \\
\hline \multirow{2}{*}{ } & \multirow{2}{*}{ rag } & \multirow{2}{*}{$\cdot, 7 \cdot V$} & $\cdot, r 99$ & 1,or & vi & طلاب صعوبات \\
\hline & & & $\cdot, r 90$ & 1,89 & YQ7 & طلاب عاديين \\
\hline \multirow{2}{*}{ } & \multirow{2}{*}{$1 \leqslant r$} & \multirow{2}{*}{$1, \varepsilon V$} & $\cdot, \Sigma Y$ & $1, \varepsilon 1$ & 19 & طالبـات صعوبـات \\
\hline & & & דצ, • & $1, r$. & IYT & طالبـات عاديـين \\
\hline
\end{tabular}

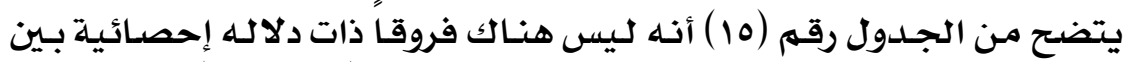

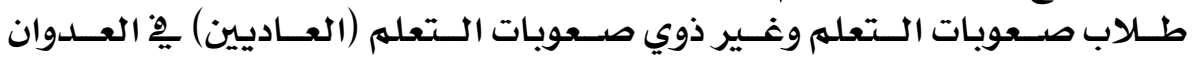

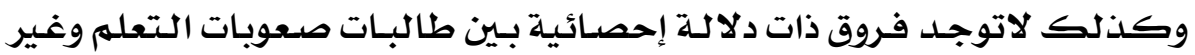

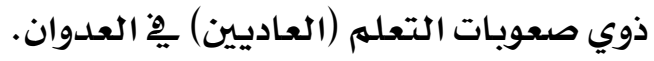

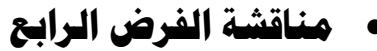

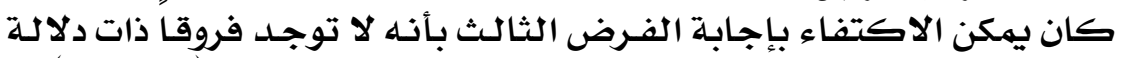

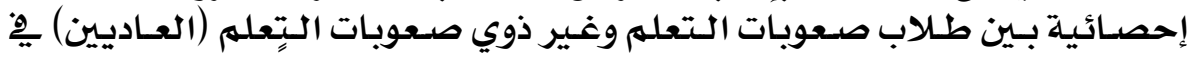

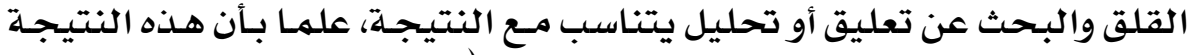

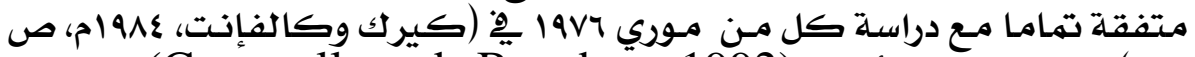

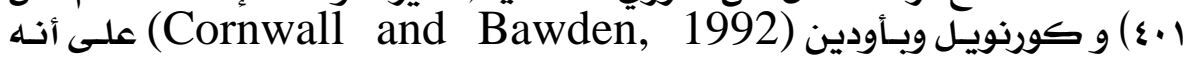

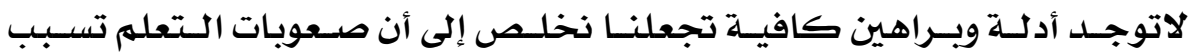

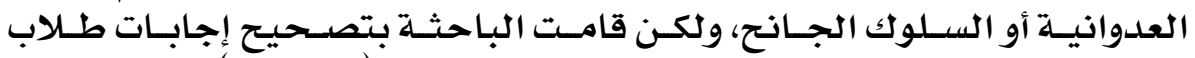

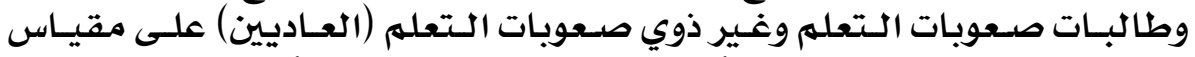

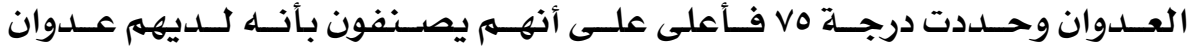

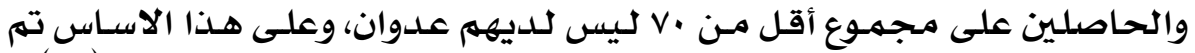

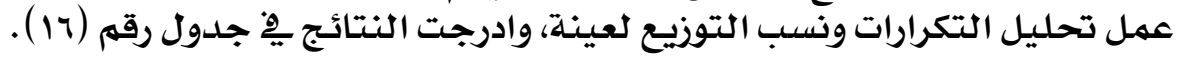

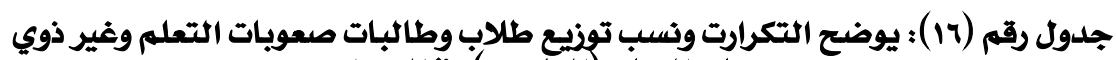

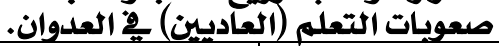

\begin{tabular}{|c|c|c|c|c|}
\hline \multirow{2}{*}{ الشــــرح } & \multicolumn{2}{|c|}{ لديهم عدوان } & \multirow{2}{*}{\multicolumn{2}{|c|}{ توصيف العينة }} \\
\hline & عاديـين & ذوي صعوبات & & \\
\hline \multirow{2}{*}{ 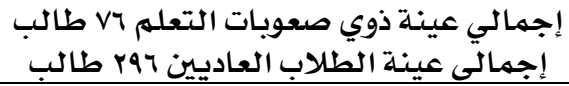 } & m & 9 & 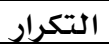 & \multirow[t]{2}{*}{ ذكر } \\
\hline & $\%, Y, Y$ & $\% 11, \wedge$ & & \\
\hline إجمالي عينـة ذوي صعوبات التعلم 19 طالبـة & $r$ & r & 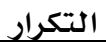 & \multirow[t]{2}{*}{ 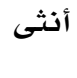 } \\
\hline إجمالى عينـة الطالبـات العاديين جrا طالبـة & $\%, Y, \mathcal{\varepsilon}$ & $\% 1 \cdot, 0$ & النسبية ال النية & \\
\hline
\end{tabular}

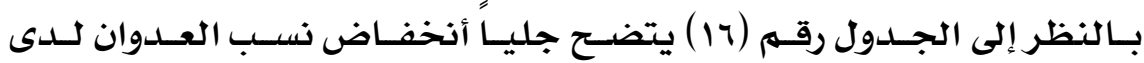

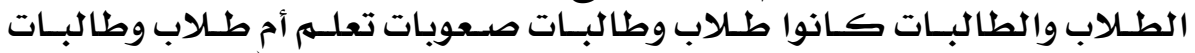

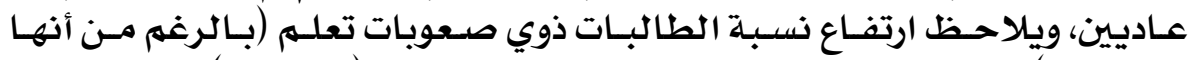

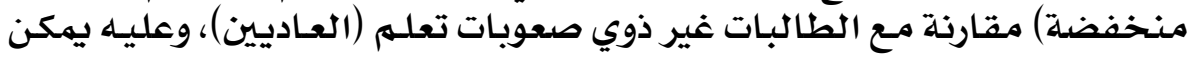

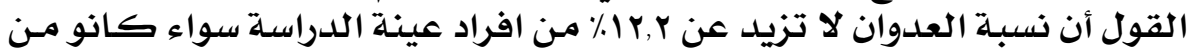




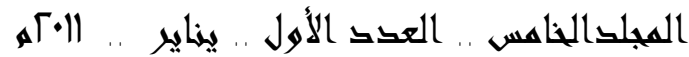

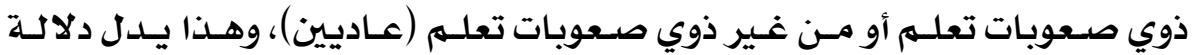

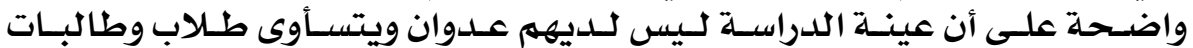

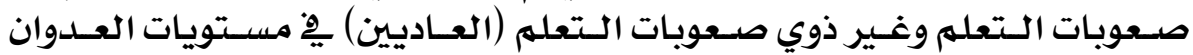

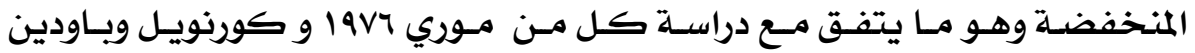

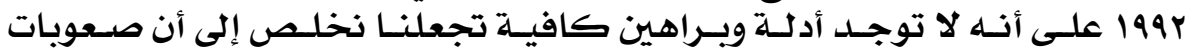

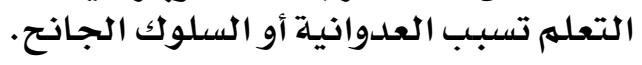

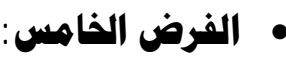

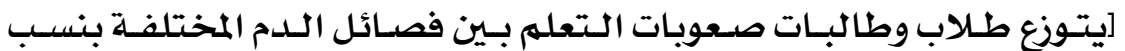

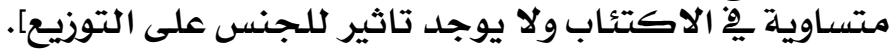

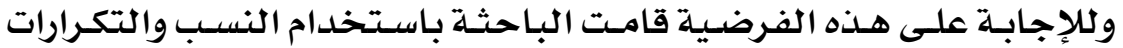

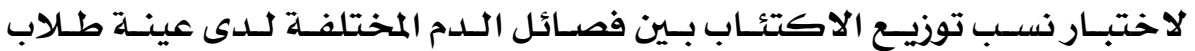

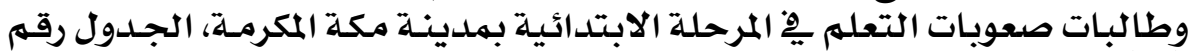

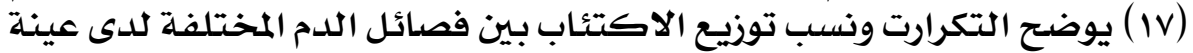

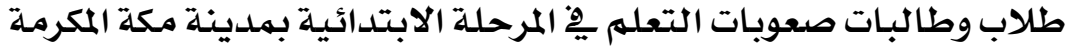

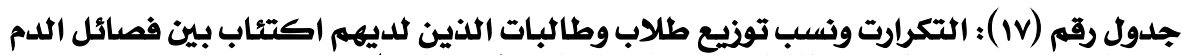

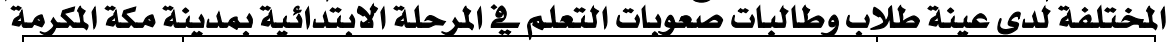

\begin{tabular}{|c|c|c|c|c|c|c|}
\hline \multirow{3}{*}{ المجموع } & \multicolumn{4}{|c|}{ فصيـلة الــلـم } & \multirow{2}{*}{\multicolumn{2}{|c|}{ الجنس }} \\
\hline & $\mathrm{O}$ & B & $\mathrm{AB}$ & $\mathrm{A}$ & & \\
\hline & $v$ & ro & 1 & $r$ & التكرار & \\
\hline$\% 1 \ldots$ & $\% 10,7$ & $\% \vee V, \Lambda$ & $\%, Y, Y$ & $\% \varepsilon, \varepsilon$ & النسبية & دصر \\
\hline Ir & 7 & $r$ & صفر & $r$ & التكرار & \\
\hline$\% 1 \ldots$ & $\%$ & $\%$ ro & صفر & $\%$ ro & النسسـة & السى \\
\hline
\end{tabular}

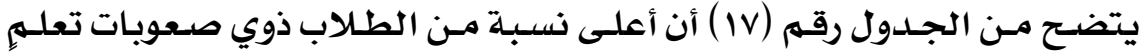

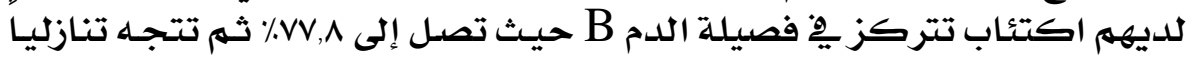

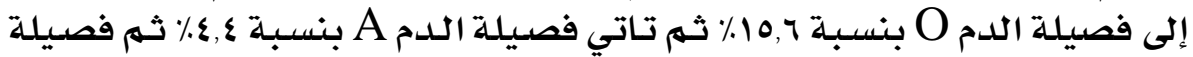

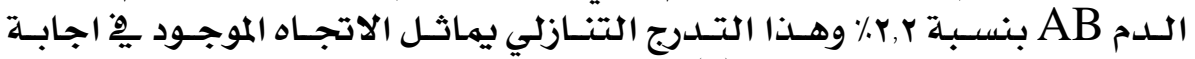

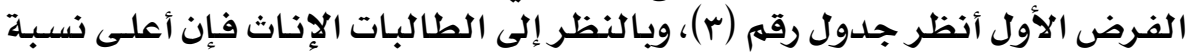

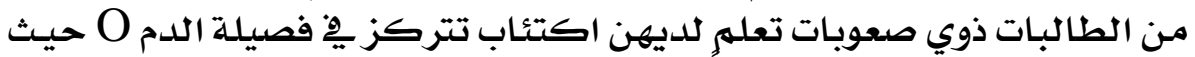

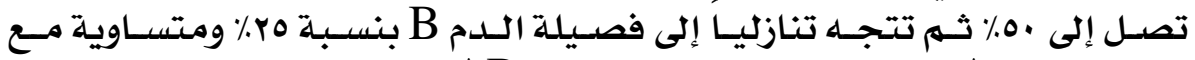

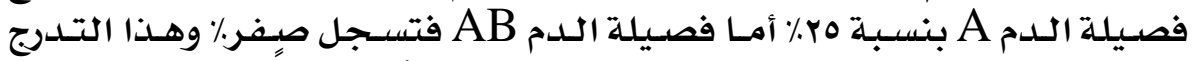

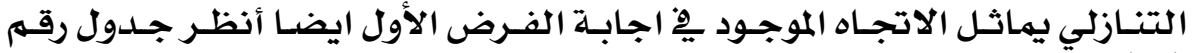

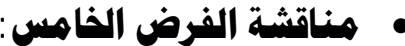

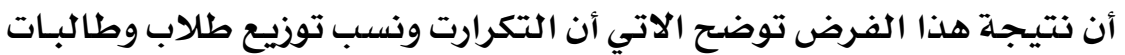

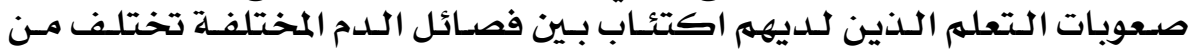




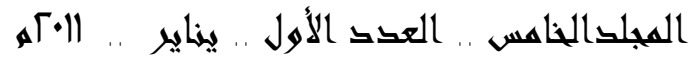

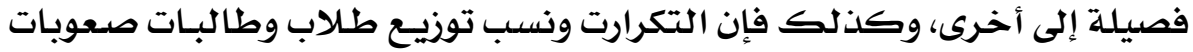

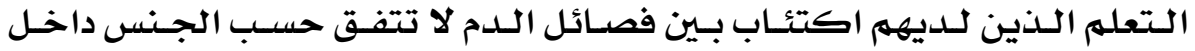

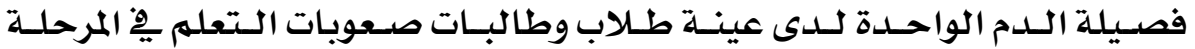

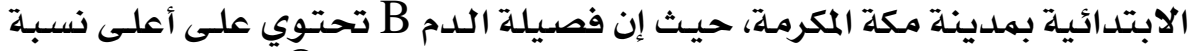

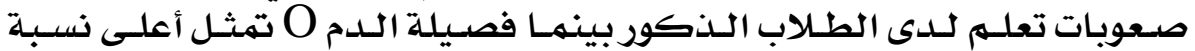

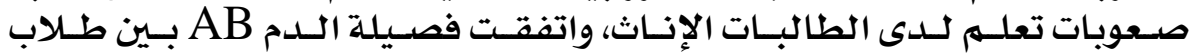

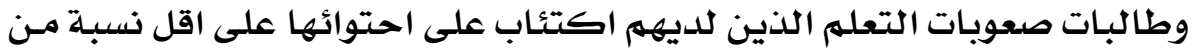

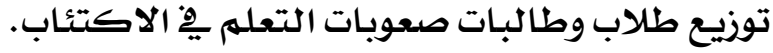

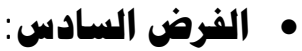

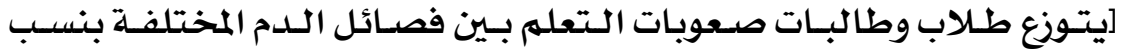

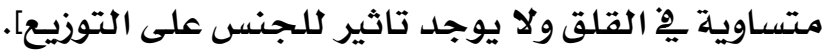

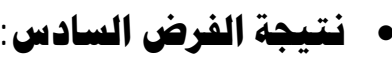

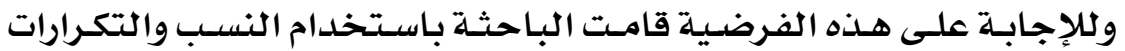

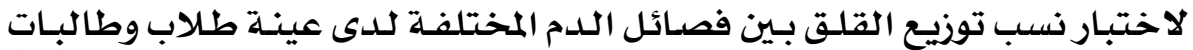

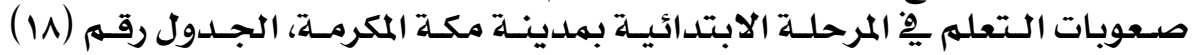

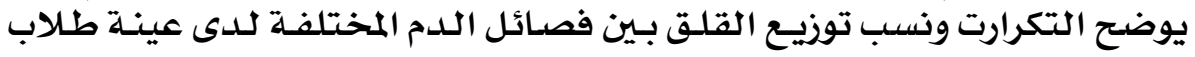

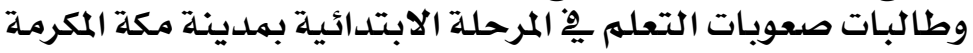

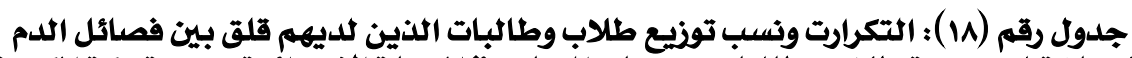

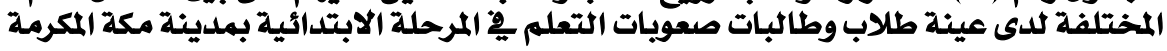

\begin{tabular}{|c|c|c|c|c|c|c|}
\hline \multirow{3}{*}{ المجموع } & \multicolumn{4}{|c|}{ فصيـلـة الــــم } & \multirow{2}{*}{\multicolumn{2}{|c|}{ الجنس }} \\
\hline & $\mathrm{O}$ & B & $\mathrm{AB}$ & A & & \\
\hline & ir & $\varepsilon r$ & 1 & $\varepsilon$ & التكرار & \multirow{2}{*}{ :كر } \\
\hline$\% 1 .$. & $\% r$. & $\% \vee १, V$ & $\%, \mathrm{~V}$ & $\%, \mathrm{~V}$ & النسبة & \\
\hline 10 & 7 & 0 & صفر & $\varepsilon$ & التكرار & \multirow{2}{*}{ أنثى } \\
\hline$\% 1 \ldots$ & $\%$. . & 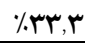 & صفر٪ & $\%$ \% & النسبة & \\
\hline
\end{tabular}

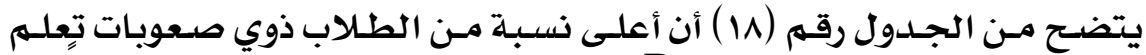

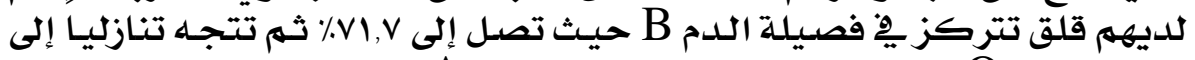

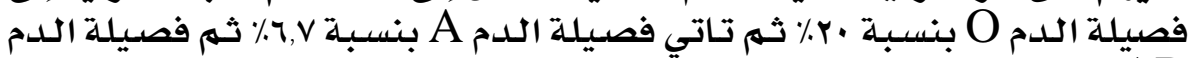

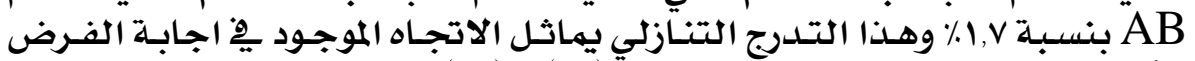

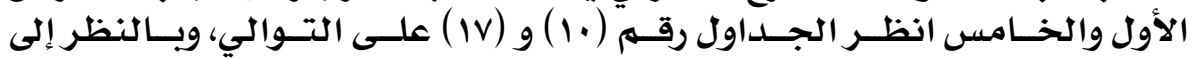

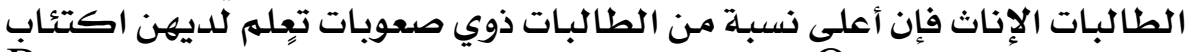

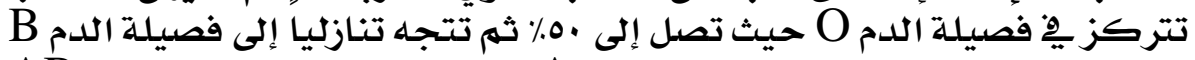

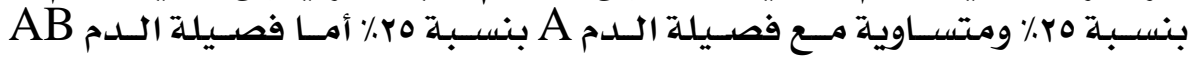

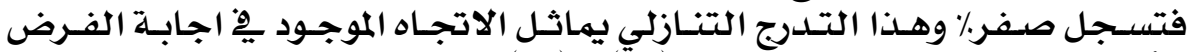

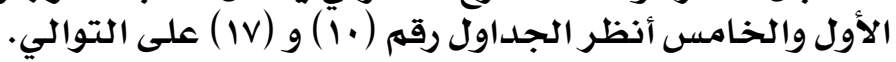




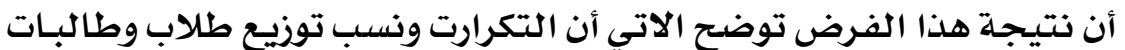

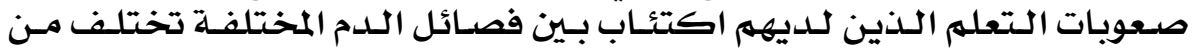

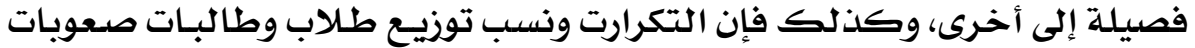

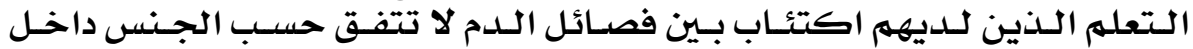

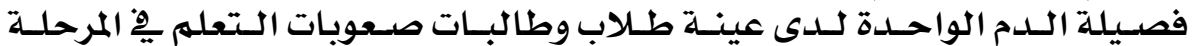

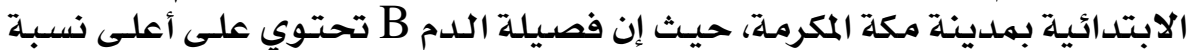

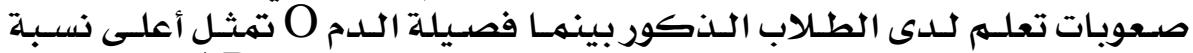

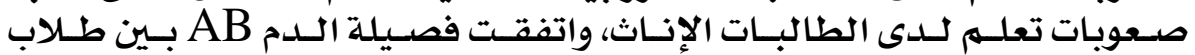

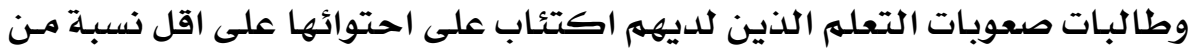

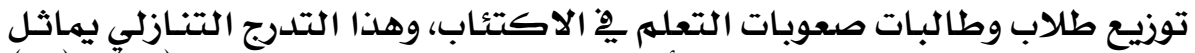

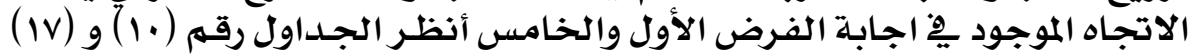
على التوالي.

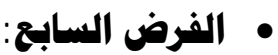

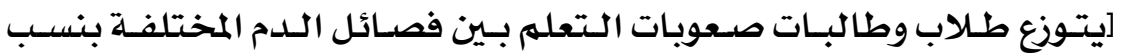

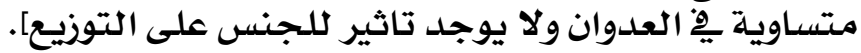

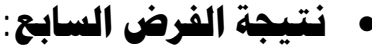

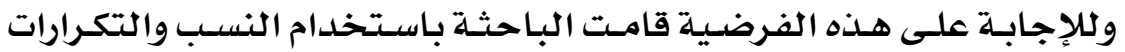

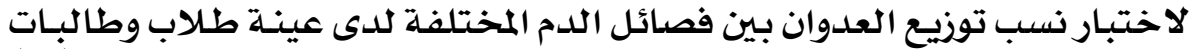

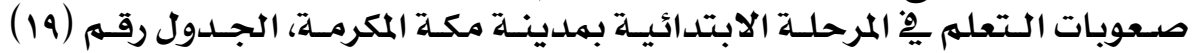

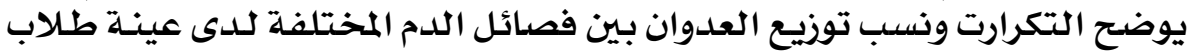

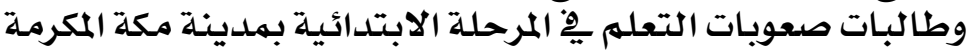

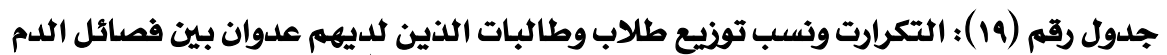

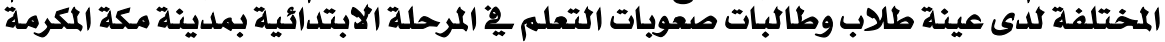

\begin{tabular}{|c|c|c|c|c|c|c|}
\hline \multirow{3}{*}{ المجموع } & \multicolumn{4}{|c|}{ فصيـلة الــــم } & \multirow{2}{*}{\multicolumn{2}{|c|}{ الجنس }} \\
\hline & \multirow{2}{*}{$\begin{array}{l}\mathrm{O} \\
\end{array}$} & \multirow{2}{*}{$\begin{array}{l}\mathrm{B} \\
\mathrm{V}\end{array}$} & \multirow{2}{*}{ صفر } & \multirow{2}{*}{ صفر } & & \\
\hline & & & & & التكرار & \multirow{2}{*}{ ذكر } \\
\hline$\% 1 \ldots$ & $\%, Y Y, Y$ & $\% \vee V, \Lambda$ & صفر٪\% & صفر٪ & النسبيـة & \\
\hline$r$ & 1 & صفر & صفر & 1 & التكرار & \multirow{2}{*}{ أنثى } \\
\hline$\% 1 \ldots$ & $\%$. & صفر٪\% & صفر٪ & $\%$. & النسبـة & \\
\hline
\end{tabular}

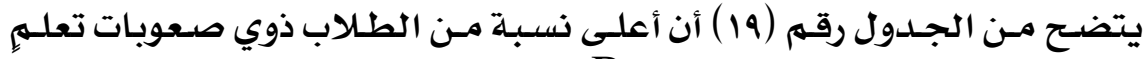

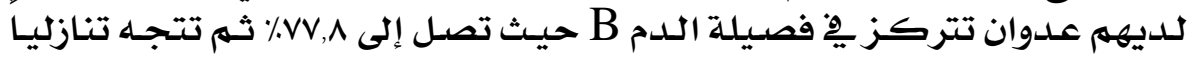

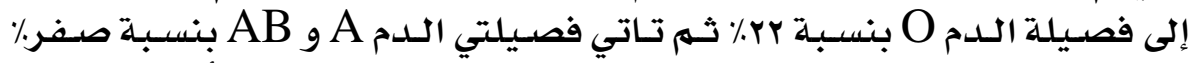

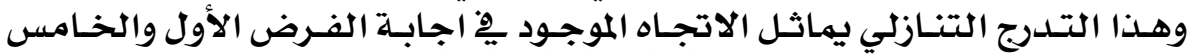

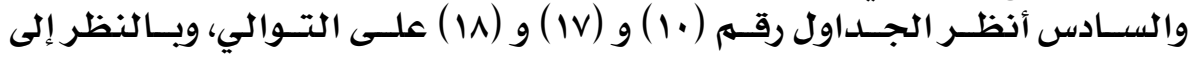

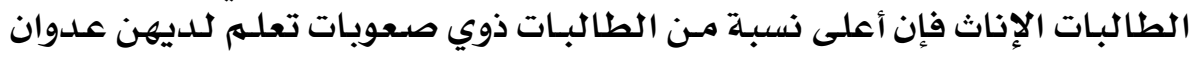

\section{$\boldsymbol{r}, \boldsymbol{r}$}


المجلىالخاهس .. العكى الأول .. بيناير .. 1ا•؟م.

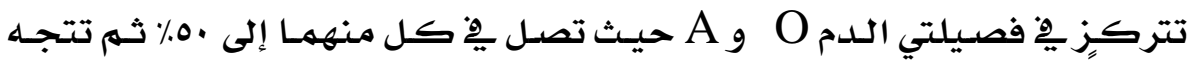

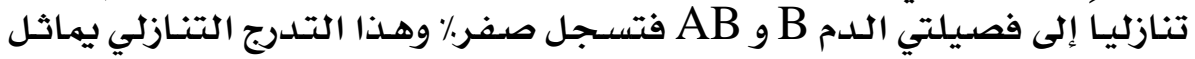

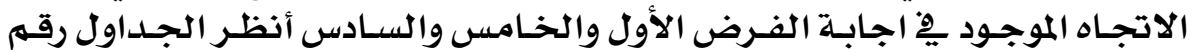

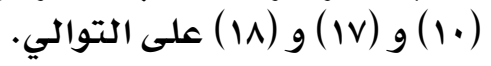

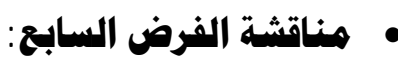

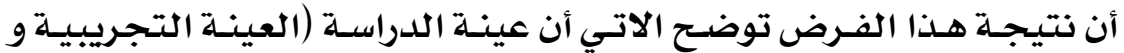

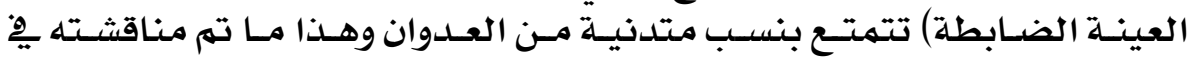

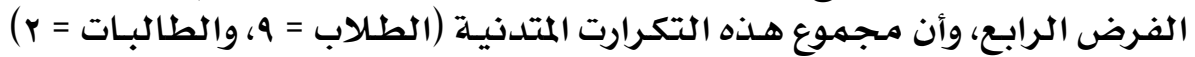

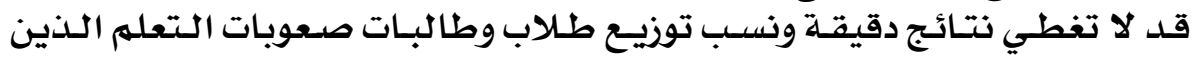

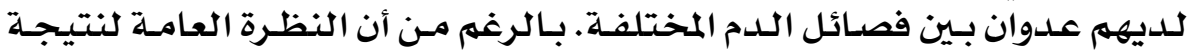

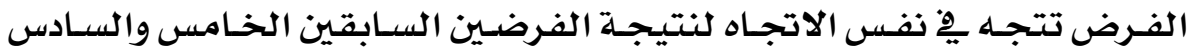

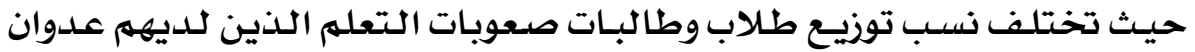

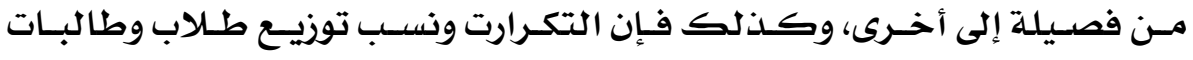

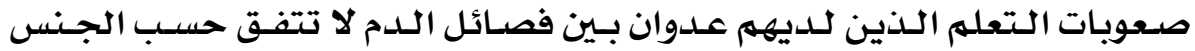

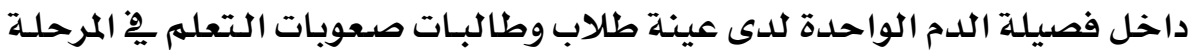

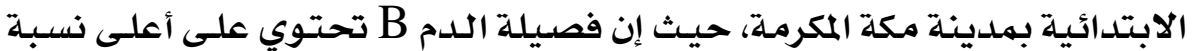

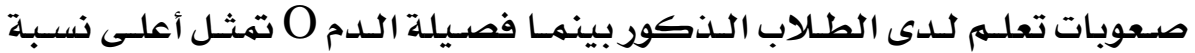

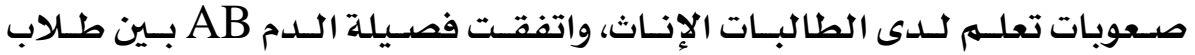

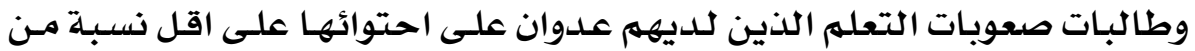

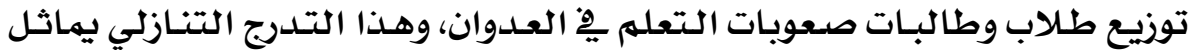

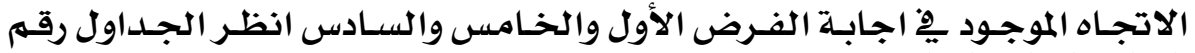

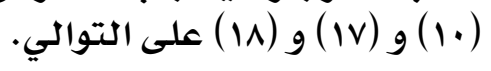

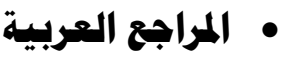

ا ـ ابـو عـلام، رجـاء و شـريف، ناديـة (سه9 ام) الفـروق الفرديـة وتطبيقاتها التربويـة، دار العلهم

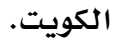

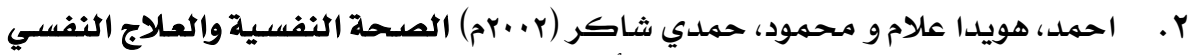

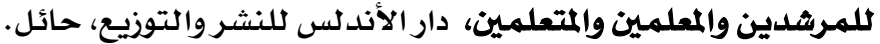

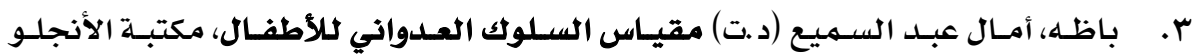
المصريـة، القاهرة. أمال

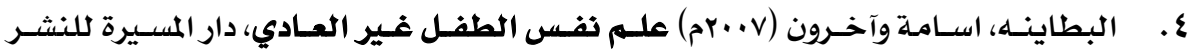
والتوزيع، عمان، الاردن.

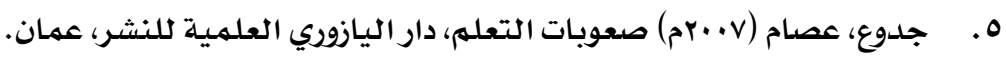

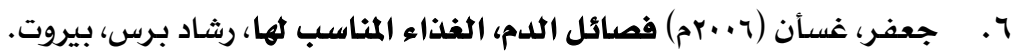

\section{$\boldsymbol{r}, \varepsilon$}




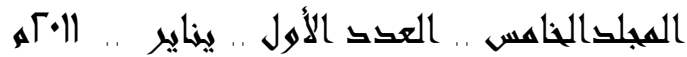

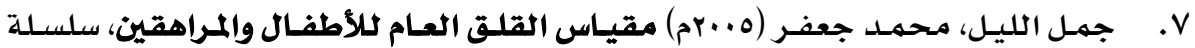

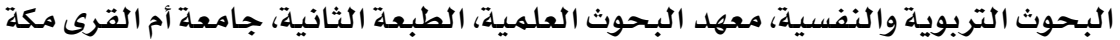
المكرمة، المملكة العربية السعودية.

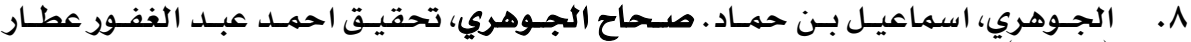

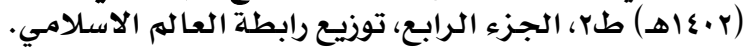

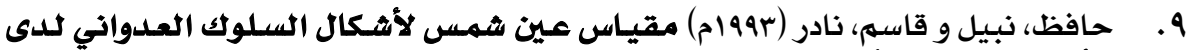
الأطفال، مكتبة الأنجلو المصرية، القاهرة.

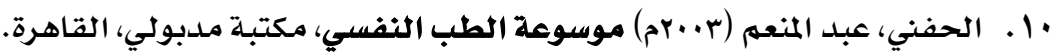

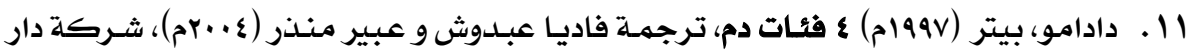

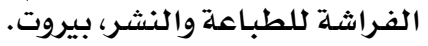

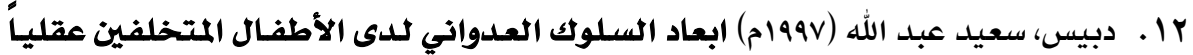

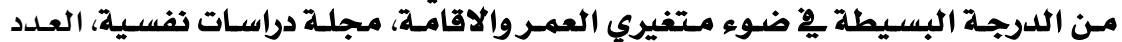

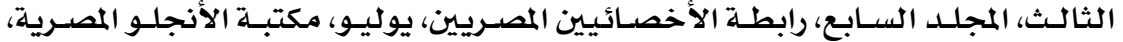
القاهرة.

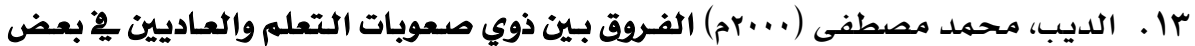

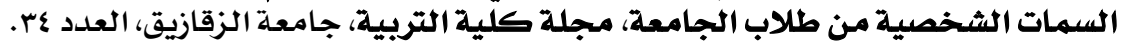

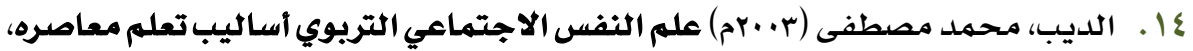
عاله الكتب للنشروالتوزيع، القاهرة.

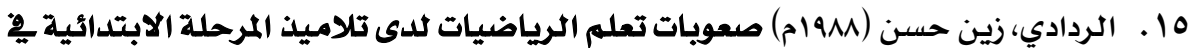

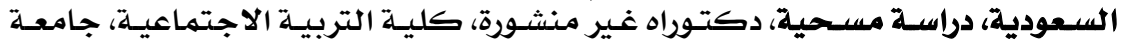

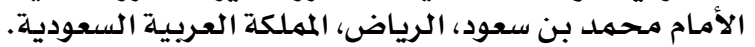

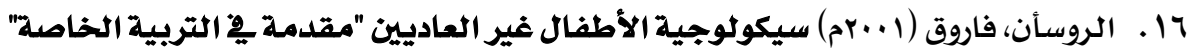
دار الفكر للنشر والطباعة، عمان، الأردن.

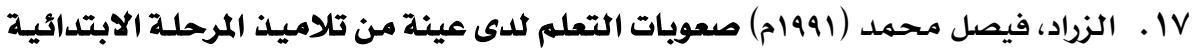

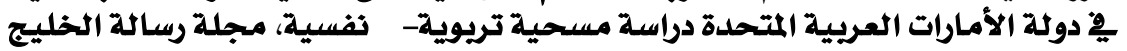

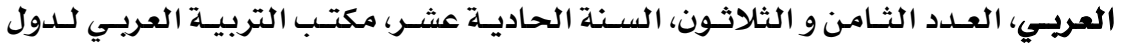
الخليج، الرياض، المملكة العربية النئلون، السعودية.

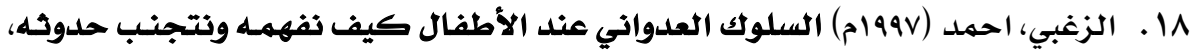

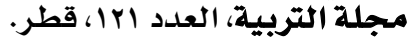

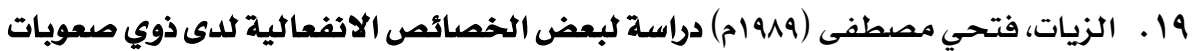

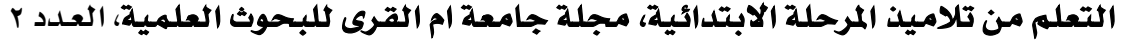

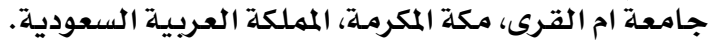

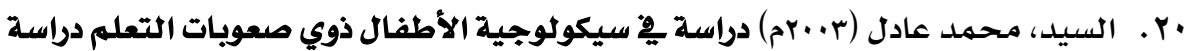

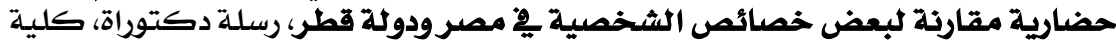
الآداب، قسم علم النفس، جامعة عيد عين شمس، القاهرة. 
المجلى للخاهس .. العك الأول .. يناير .. الآمه

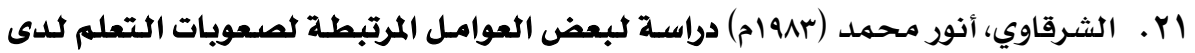
تلاميذ المرحلة الابتدائية بلدولة الكويت، مجلة دراسية دراسات الخليج، الكويت.

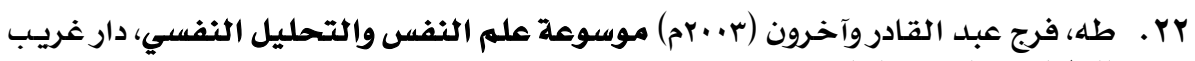
لبطباعة والنشر، القاهرة.

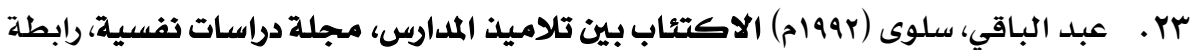
الأخصائيين المصريين، يوليو، مكتبة الأنجلو المصرية، الألقاهرة.

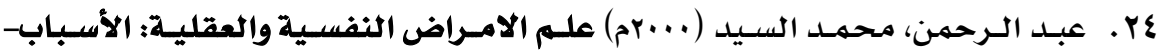
الاعراض- التشخيص- العلاج، دار قباء للطباعة والتوزيـع، القاهرة.

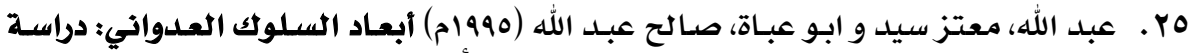

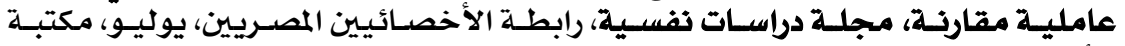
الأنجلو المصرية، القاهرة.

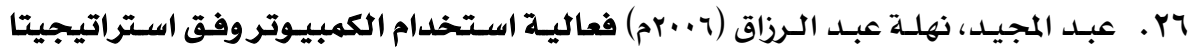

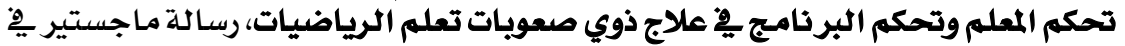

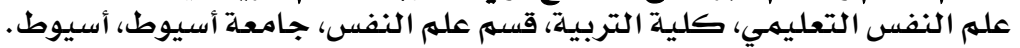

rV والتشخيصية، دار الوفاء للطباعة والنشر، الاسكندرية.

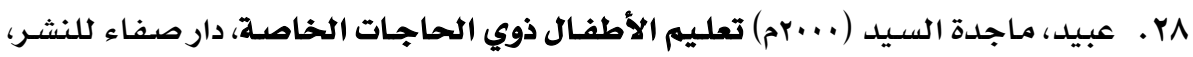
عمان.

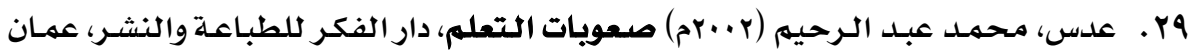

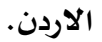

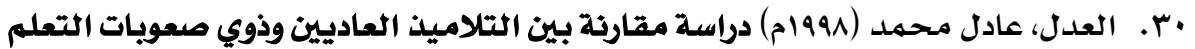

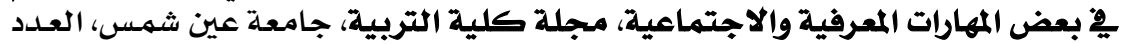

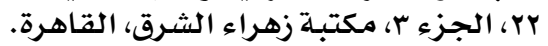

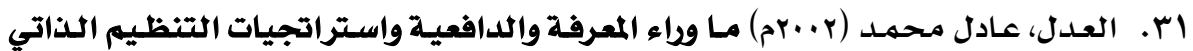

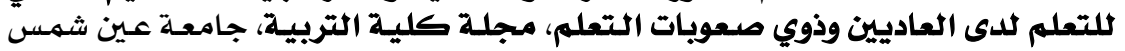

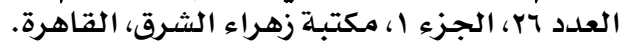

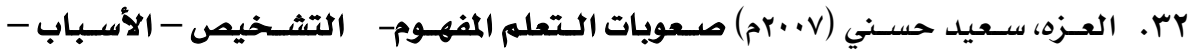

أساليب التدريس واستراتجيات العلاج، دار الثقافة للنشر والتومه التوزيع، عمـان، الاردن.

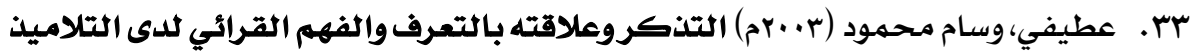

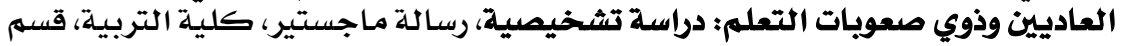

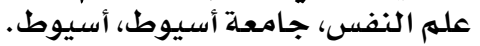

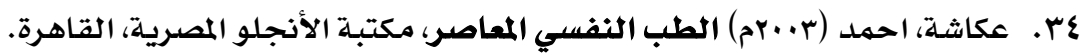

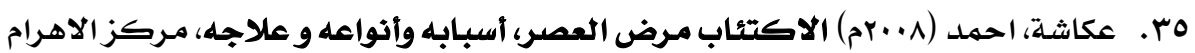

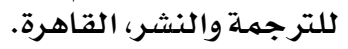

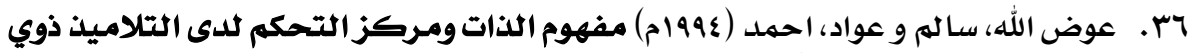
صعوبات التعلم، مجلة الإرثاد النفسي، جامعة عين شمس، العداد العد الثاني، القاهرة. 
المجلى للخاهس .. العك الأول .. يناير .. الآم

$$
\begin{aligned}
& \text { NVV }
\end{aligned}
$$

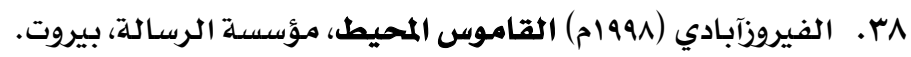

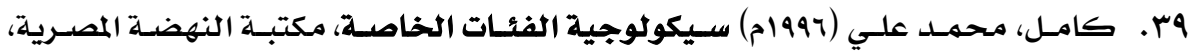

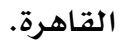

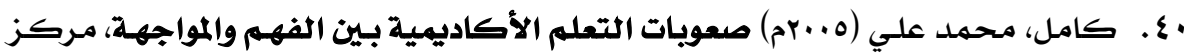

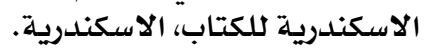

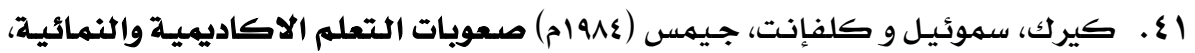

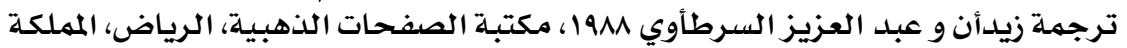

$$
\text { العربية السعودية. }
$$

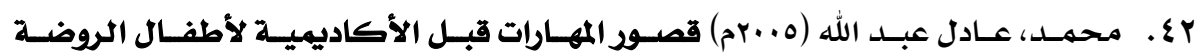

$$
\text { وصعوبات التعلم دار الرشاد، القاهرة. }
$$

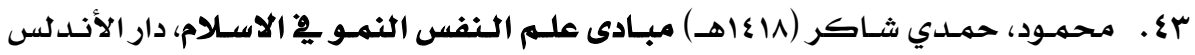
للنشروالتوزيـع، حائل.

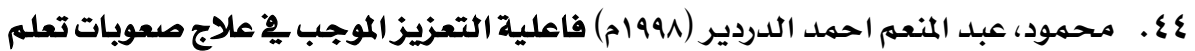

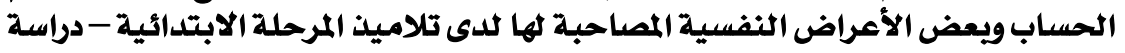

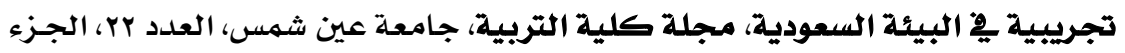

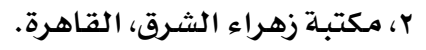

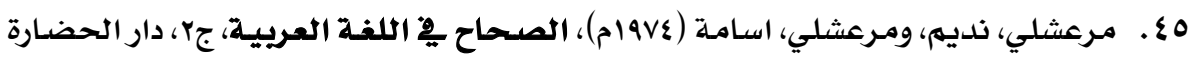

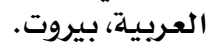

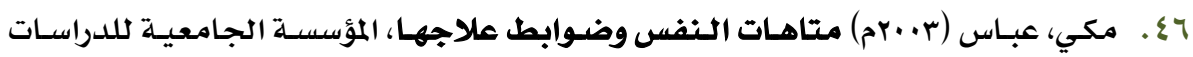

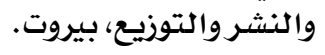

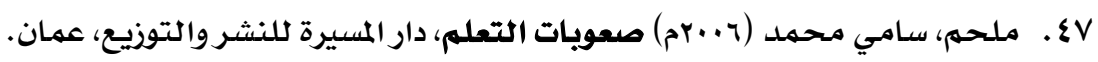

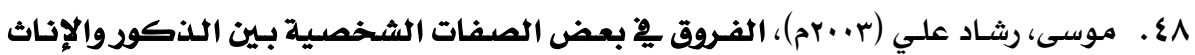

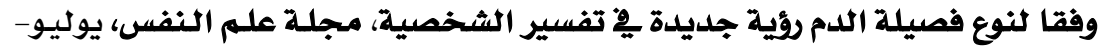

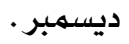

9؟ . الموسى، ناصر بن علي (ج . بrم)، المؤتمر الدولي لصعوبات التعلم، الرياض، المملكة العربية

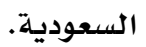

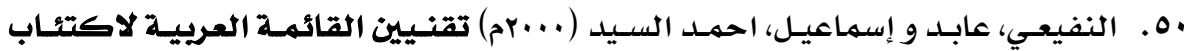

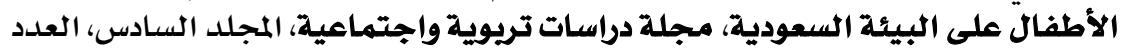

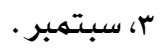

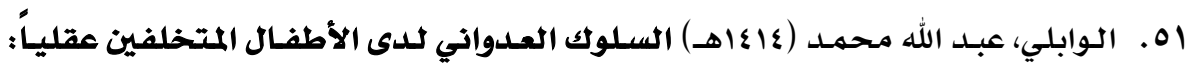

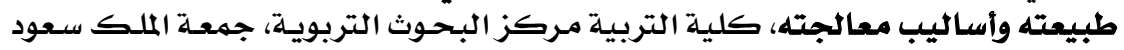

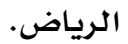

\section{$r \cdot V$}


52. Angest, J., and Maurer-Groeli, Y. (1974) "Blood groups and personality" Archiv fur Psychiatric and Nervenkrankbeiten, Vol. (218), pp. 291-300.

53. Burck, M. (1986), "Social and emotional adjustments of learning disabled children: Areview of the issues" Handbook of Cognitive, social and neuro psychological aspects of learning disabilities

54. Cattell, R. B., Boutourline, H. Y., and Hundleby, J. D. (1964) "Blood groups and personality traits" American Journal of Human Genetics, Vol. (16), pp. 397-402.

55. Cattell, R. B., Brackenridge, C. J., Case, J., Propert, D. N., and Sheehy, A. J. (1980) "The relation of blood types to primary and secondary personality traits" The Mankind Quarterly, Vol. (21), pp. 35-51.

56. Cornwall, A., and Bawden, H. (1992), "Reading disabilities and aggression: A critical review", Journal of Learning Disabilities, Vol. 25 (5), pp. 281-288.

57. Coronado, V., and Marco, A., (1995), "The anxiety of learningdisabled school children with remedial instruction", Dissertation Abstracts International, Vol. 55 (10 A), pp. 3154.

58. Cramer, K. M., and Imaike, E. (2002) "Personality, blood type, and five-factor model" Personality and Individual differences, Vol. (32), pp. 621-626.

59. Daniels, G., Human blood groups, second ed., (2002) Blackwell Science.

60. de Mikusinski, E. B., and Omar de Urteaga, A. G. (1983) "The blood group as a genetic determinator of personality types" Interdisciplinaria, Vol. (4), pp. 153-166.

61. Eysenck, H. J. (1977) "National differences in personality as related to ABO group polymorphism" Psychological Reports, Vol. (41), pp. 1257-1258.

62. Eysenck, H. J. (1982) "The biological basis of cross-cultural differences in personality: Blood group antigens" Psychological Reports, Vol. (51), pp. 531-540. 
المجلى للخاهس .. العك الأول .. يناير .. الآمه

63. Fisher, B. L., Allen, R., Kose, G., (1996) " The relationship between anxiety and problem-solving skills in children with and without learning disabilities", Journal of Learning Disabilities, Vol. 29 (4), pp. 439-446.

64. Gupta, S. (1990) "Blood groups and personality characteristics" Personality and Individual Differences, Vol. (3), pp. 317-318.

65. Gupta, S. (1992) "Season of birth in relation to personality and blood groups" Personality and Individual Differences, Vol. (13), pp. 631-633.

66. Hoy, C., Gregg, N., Wisenbaker, J., Manglitz, E., King, M. and Moreland, C., (1997) "Depression and anxiety in two groups of adults with learning disabilities", Learning Disability Quarterly, Vol. 20 (4): pp. 280-291.

67. Hutchinson, K., (1985) "Psycho-social characteristics of learning disabled vs. non-learning disabled students" Dissertation Abstracts International, Vol. 46 (2B), pp. 643.

68. Jogawar, V. V. (1983) "Personality correlates of human blood groups", Personality and Individual differences, Vol. (4), pp. 215-216.

69. Johnson, W. D. (1997) "Social anxiety and self-esteem in children with a learning disability", Dissertation Abstracts International, Vol. 58 (4A), pp. 1245.

70. Johnstone, H. B. (1985) "Understanding Reading Disability a Case Study Approach", Harvard Education Review, Vol. 55 (2), pp.1953-1977.

71. Kay, J. (1995) "Attributional style depression, and anxiety in college students with and without learning disabilities", Dissertation Abstracts International: Section B: The Sciences and Engineering, Vol. 56(5-B) :2869.

72. Kenyon, R. (2003) "Facts and statistics on learning disabilities and literacy" A project of Florida human resources development, Inc, pp. 1-15.

73. Kovas, Y., Hayiou-Thomas, M. E., Oliver, B., Bishop, D. V. M., Dale, P. S., Plomin, R. (2005) "Genetic influences in different aspects of language development: The etiology of language skills in 4-5 year-old twins" Child development, Vol. 76 (3), pp. 632-651. 
المجلى للخاهس .. العك الأول .. يناير .. الآمر

74. Lester, D., and Gatto, J. (1987) "personality and Blood groups" Personality and Individual Differences, Vol. (8), pp. 267.

75. Lester, D. (2004) "Blood types and national suicide rates" Crisis: The Journal of Crisis Intervention and Suicide Prevention, Vol. 25 (3), pp. 140.

76. Luntta, M. H., (1996) "An investigation of empathy and social anxiety in learning disabled and non-learning disabled male college students" Dissertation Abstracts International: Section B: The Sciences and Engineering, Vol. 56 (11-B) :6465.

77. Marutham, P., and Prakash, I. J. (1990) "A study of the possible relationship of blood types to certain personality variables" Indian Journal of Clinical Psychology, Vol. (17), pp. 79-81.

78. McClain, G., A., (1998) "Success/failure attributions, academic self-concept and the internalizing patterns of anxiety and depression in middle school males with learning disabilities", Dissertation Abstracts International: Section B: The Sciences and Engineering, Vol. 58 (12-B) :6816.

79. McConaughy, S. H. and Ritter, D. R., (1988) " Social competence and behavioral problems of of learning disabilities boys aged 6-11" Journal Learning disabilities, Vol. 19, pp. 39.

80. Mescher, S., (1987) "Relationship of personality and cognitive style to spelling achievement of learning disabled children in three competitive environment" Dissertation Abstracts International, Vol. 47 (9B), pp. 3998.

81. Newcomer, P. L., Barenbaum, E., and Pearson, N., (1995) "Depression and anxiety in children and adolescents with learning disabilities, conduct disorders, and disabilities" Journal of Emotional and Behavioral Disorders, Vol. 3 (1), pp. $27-39$.

82. Patenaude A. F., (2003) "Pediatric psychology training and genetics: What will twenty-first-century Pediatric psychologist need to know" Journal of Pediatric Psychology, Vol., 28 (2), pp. 135.

83. Paulesu E., Frith U., Snowling M., Gallagher A., Morton J., Frackowiak RS. and Frith CD (1996) "Is developmental dyslexia a disconnection syndrome? Evidence from PET scanning" Brain: A Journal Of Neurology [Brain] Vol. 119 (1), pp. 143-57. 
المجلدالخاهس .. العقد الأول .. بيناير .. المه

84. Raskind, W. H., (2001) "Current understanding of the genetic basis of reading and spelling disability" Learning Disability Quarterly, Vol. 24, pp. 141-157.

85. Rogers, M. and Glendon, A. I., (2003) "Blood type and personality" Personality and Individual Differences, Vol. 34, pp. 1099-1112.

86. Swan, D. A., Hawkins, G., and Douglas, B. (1980) "The relationship between $\mathrm{ABO}$ blood type and factor of personality among south Mississippi, Anglo-Saxon, school children" The Mankind Quarterly, Vol. 20, pp. 205-258.

87. Swanson, H. L., and Malone, S. (1992) "Social skills and learning disabilities: A meta-analysis of the literature" School Psychology Review, Vol. 21 (3), pp. 427-443.

88. Voracek, M. (2005) "Some problems of research on the association between blood types and suicide mortality: Comment on Lester (2004)" Crisis: The Journal of Crisis Intervention and Suicide Prevention, Vol. 26 (4), pp. 181-189.

89. Voughn, S., Hogan, A., Kouze Kanani, K., and Shapir, S. (1990): "Peer acceptance self perception and social skill of learning diabilities students prior to identification" Journal of Educational Psychology, Vol. 82 (1), pp. 101-106.

90. Wikipedia, the free encyclopedia, (http://en.wikipedia.org/wiki/ Blood type) and (http://en.wikipedia.org/wiki/Blood type\# Cultural_beliefs_and_other_claims).

91. Wu, K., Lindsted, K. D., and Lee, J. W. (2005) "Blood type and the five factors of personality in Asia" personality and Individual Differences, Vol. 38, pp. 797-808.

\section{$* * * * * * *$}

